Prepared in cooperation with the Montana Department of Transportation

Peak-Flow Variability, Peak-Flow Informational Needs, and Consideration of Regional Regression Analyses in Managing the Crest-Stage Gage Network in Montana

Scientific Investigations Report 2021-5063 



\section{Peak-Flow Variability, Peak-Flow Informational Needs, and Consideration of Regional Regression Analyses in Managing the Crest-Stage Gage Network in Montana}

By Steven K. Sando

Prepared in cooperation with the Montana Department of Transportation

Scientific Investigations Report 2021-5063 


\section{U.S. Geological Survey, Reston, Virginia: 2021}

For more information on the USGS - the Federal source for science about the Earth, its natural and living resources, natural hazards, and the environment—visit https://www.usgs.gov or call 1-888-ASK-USGS.

For an overview of USGS information products, including maps, imagery, and publications, visit https://store.usgs.gov/.

Any use of trade, firm, or product names is for descriptive purposes only and does not imply endorsement by the U.S. Government.

Although this information product, for the most part, is in the public domain, it also may contain copyrighted materials as noted in the text. Permission to reproduce copyrighted items must be secured from the copyright owner.

Suggested citation:

Sando, S.K., 2021, Peak-flow variability, peak-flow informational needs, and consideration of regional regression analyses in managing the crest-stage gage network in Montana: U.S. Geological Survey Scientific Investigations Report 2021-5063, 124 p., https://doi.org/10.3133/sir20215063.

Associated data for this publication:

Dutton, D.D., Sando, R., and Sando, S.K., 2021, Drainage-basin characteristics associated with 12,639 road and stream intersections in Montana: U.S. Geological Survey data release, https://doi.org/10.5066/P9NZX5TM.

U.S. Geological Survey, 2018, USGS water data for the Nation: U.S. Geological Survey National Water Information System database, https://doi.org/10.5066/F7P55KJN.

ISSN 2328-0328 (online) 


\section{Acknowledgments}

The authors would like to recognize the U.S. Geological Survey hydrologic technicians involved in the collection of streamflow data for their dedicated efforts. The authors also would like to recognize the valuable contributions to this report from the insightful technical reviews by Karen Ryberg, Nancy Barth, and Kathy Chase of the U.S. Geological Survey. 



\section{Contents}

Acknowledgments ……...................................................................................................................

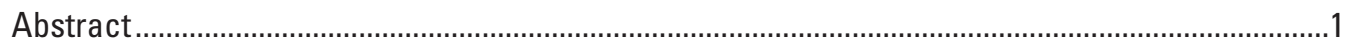

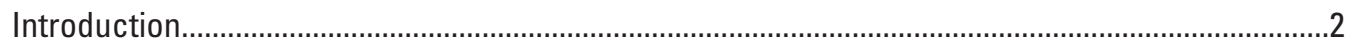

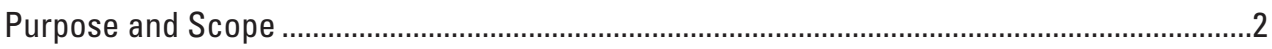

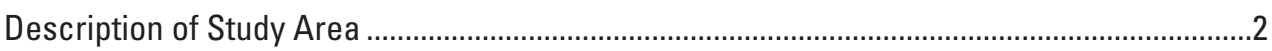

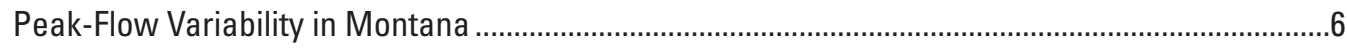

General Characterization of Peak-Flow Informational Needs in Montana....................................18

Consideration of Regional Regression Analyses in Managing the Crest-Stage Gage Network....26

Description of Peak-Flow Variability and Peak-Flow Informational Needs, and

Consideration of Regional Regression Analyses by Hydrologic Region..............................32

Peak-Flow Variability, Peak-Flow Informational Needs, and Consideration of

Regional Regression Analyses in the West Hydrologic Region ...................................32

Peak-Flow Variability, Peak-Flow Informational Needs, and Consideration of

Regional Regression Analyses in the Northwest Hydrologic Region ..........................37

Peak-Flow Variability, Peak-Flow Informational Needs, and Consideration of

Regional Regression Analyses in the Northwest Foothills Hydrologic Region ..........60

Peak-Flow Variability, Peak-Flow Informational Needs, and Consideration of

Regional Regression Analyses in the Northeast Plains Hydrologic Region ...............68

Peak-Flow Variability, Peak-Flow Informational Needs, and Consideration of

Regional Regression Analyses in the East-Central Plains Hydrologic Region ...........72

Peak-Flow Variability, Peak-Flow Informational Needs, and Consideration of

Regional Regression Analyses in the Southeast Plains Hydrologic Region ...............82

Peak-Flow Variability, Peak-Flow Informational Needs, and Consideration of

Regional Regression Analyses in the Upper Yellowstone-Central Mountain

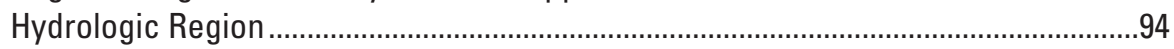

Peak-Flow Variability, Peak-Flow Informational Needs, and Consideration of

Regional Regression Analyses in the Southwest Hydrologic Region ........................103

Synopsis of Possible Shortcomings of and Future Improvements to the

Streamgaging Network in Montana.................................................................114

Synopsis for the West Hydrologic Region ..............................................................114

Synopsis for the Northwest hydrologic region ..........................................................114

Synopsis for the Northwest Foothills hydrologic region ...............................................118

Synopsis for the Northeast Plains hydrologic region ..................................................118

Synopsis for the East-Central Plains hydrologic region................................................118

Synopsis for the Southeast Plains hydrologic region....................................................119

Synopsis for the Upper Yellowstone-Central Mountain hydrologic region ...................119

Synopsis for the Southwest hydrologic region.........................................................119

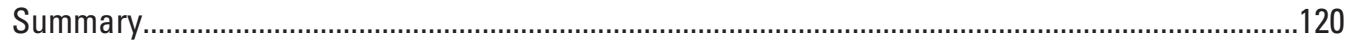

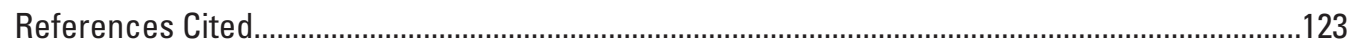

\section{Figures}

1. Map showing locations of hydrologic regions and selected streamgages in or near Montana. 
2. Graphs showing relations between peak-flow variability index and selected drainage-basin and streamgage characteristics for 659 unregulated streamgages in or near Montana

3. Graphs showing relations between contributing drainage area and mean basin elevation, mean annual precipitation, and years of peak-flow records for 659 unregulated streamgages in or near Montana.

4. Graphs showing locally weighted scatterplot smooths fitted through relations between peak-flow variability index and contributing drainage area, mean basin elevation, mean annual precipitation, and years of peak-flow records for each hydrologic regions in Montana

5. Graphs showing cumulative distribution functions of selected drainage-basin characteristics for 12,639 road and stream intersections and for 735 streamgages in or near Montana

6. Graphs showing relations between peak-flow variability index and contributing drainage area, mean basin elevation, mean annual precipitation, and years of peak-flow records for 133 unregulated streamgages in the West hydrologic region ....44

7. Graphs showing relations between contributing drainage area and mean basin elevation, mean annual precipitation, and years of peak-flow records for 133 unregulated streamgages in the West hydrologic region

8. Graphs showing cumulative distribution functions of selected drainage-basin characteristics for 2,380 road and stream intersections and for 141 streamgages in the West hydrologic region.

9. Graphs showing relations between peak-flow variability index and contributing drainage area, mean basin elevation, mean annual precipitation, and years of peak-flow records for 44 unregulated streamgages in the Northwest hydrologic region

10. Graphs showing relations between contributing drainage area and mean basin elevation, mean annual precipitation, and years of peak-flow records for 44 unregulated streamgages in the Northwest hydrologic region

11. Graphs showing cumulative distribution functions of selected drainage-basin characteristics for 356 road and stream intersections and for 49 streamgages in the Northwest hydrologic region

12. Graphs showing relations between peak-flow variability index and contributing drainage area, mean basin elevation, mean annual precipitation, and years of peak-flow records for 40 unregulated streamgages in the Northwest Foothills hydrologic region

13. Graphs showing relations between contributing drainage area and mean basin elevation, mean annual precipitation, and years of peak-flow records for 40 unregulated streamgages in the Northwest Foothills hydrologic region.

14. Graphs showing cumulative distribution functions of selected drainage-basin characteristics for 1,043 road and stream intersections and for 46 streamgages in the Northwest Foothills hydrologic region.

15. Graphs showing relations between peak-flow variability index and contributing drainage area, mean basin elevation, mean annual precipitation, and years of peak-flow records for 76 unregulated streamgages in the Northeast Plains hydrologic region

16. Graphs showing relations between contributing drainage area and mean basin elevation, mean annual precipitation, and years of peak-flow records for 76 unregulated streamgages in the Northeast Plains hydrologic region 
17. Graphs showing cumulative distribution functions of selected drainage-basin characteristics for 1,470 road and stream intersections and for 88 streamgages

in the Northeast Plains hydrologic region.

18. Graphs showing relations between peak-flow variability index and contributing drainage area, mean basin elevation, mean annual precipitation, and years of peak-flow records for 102 unregulated streamgages in the East-Central Plains hydrologic region

19. Graphs showing relations between contributing drainage area and mean basin elevation, mean annual precipitation, and years of peak-flow records for 102 unregulated streamgages in the East-Central Plains hydrologic region

20. Graphs showing cumulative distribution functions of selected drainage-basin characteristics for 1,586 road and stream intersections and for 114 streamgages in the East-Central Plains hydrologic region.

21. Graphs showing relations between peak-flow variability index and contributing drainage area, mean basin elevation, mean annual precipitation, and years of peak-flow records for 74 unregulated streamgages in the Southeast Plains hydrologic region.

22. Graphs showing relations between contributing drainage area and mean basin elevation, mean annual precipitation, and years of peak-flow records for 74 unregulated streamgages in the Southeast Plains hydrologic region

23. Graphs showing cumulative distribution functions of selected drainage-basin characteristics for 1,371 road and stream intersections and for 80 streamgages in the Southeast Plains hydrologic region.

24. Graphs showing relations between peak-flow variability index and contributing drainage area, mean basin elevation, mean annual precipitation, and years of peak-flow records for 108 unregulated streamgages in the Upper Yellowstone-Central Mountain hydrologic region

25. Graphs showing relations between contributing drainage area and mean basin elevation, mean annual precipitation, and years of peak-flow records for 108 unregulated streamgages in the Upper Yellowstone-Central Mountain hydrologic region

26. Graphs showing cumulative distribution functions of selected drainage-basin characteristics for 2,166 road and stream intersections and for 113 streamgages in the Upper Yellowstone-Central Mountain hydrologic region

27. Graphs showing relations between peak-flow variability index and contributing drainage area, mean basin elevation, mean annual precipitation, and years of peak-flow records for 67 unregulated streamgages in the Southwest hydrologic region

28. Graphs showing relations between contributing drainage area and mean basin elevation, mean annual precipitation, and years of peak-flow records for 67 unregulated streamgages in the Southwest hydrologic region

29. Graphs showing cumulative distribution functions of selected drainage-basin characteristics for 2,267 road and stream intersections and for 84 streamgages in the Southwest hydrologic region

\section{Tables}

1. Geographic, climatic, and land-cover characteristics of hydrologic regions in Montana 
2. Information on hydrologic regions and Level III ecoregions in Montana ..........................5

3. Statistical summaries of peak-flow variability indices and other selected characteristics of unregulated streamgages in or near Montana

4. Statistical summaries of contributing drainage area and elevation-related and slope-related drainage-basin characteristics associated with road and stream intersections, and streamgages in or near Montana

5. Statistical summaries of climate-related and land use and land cover related drainage-basin characteristics associated with road and stream intersections, and streamgages in or near Montana.

6. Selected information concerning regional regression equations for Montana 26

7. Information on streamgages with significant leverage and influence statistics from regional regression analyses,

8. Statistical summaries of precipitation characteristics for the drainage basins of unregulated streamgages in the hydrologic regions in Montana

9. Statistical summaries of selected streamgage characteristics and drainage-basin characteristics for all streamgages included in the Montana regional regression analyses......

10. Statistical summaries of selected streamgage characteristics and drainage-basin characteristics for continuous streamgages included in the Montana regional regression analyses

11. Statistical summaries of selected streamgage characteristics and drainage-basin characteristics for crest-stage gages included in the Montana regional regression analyses

12. Information on streamgages in the West hydrologic region with significant leverage and influence in the Montana regional regression analyses.

13. Information on discontinued streamgages in the West hydrologic region that might be candidates for reactivation to improve the streamgage network

14. Information on streamgages in the Northwest hydrologic region with significant leverage and influence in the Montana regional regression analyses

15. Information on discontinued streamgages in the Northwest hydrologic region that might be candidates for reactivation to improve the streamgage network .............63

16. Information on streamgages in the Northwest Foothills hydrologic region with significant leverage and influence in the Montana regional regression analyses .........69

17. Information on discontinued streamgages in the Northwest Foothills hydrologic region that might be candidates for reactivation to improve the streamgage network.....

18. Information on streamgages in the Northeast Plains hydrologic region with significant leverage and influence in the Montana regional regression analyses

19. Information on discontinued streamgages in the Northeast Plains hydrologic region that might be candidates for reactivation to improve the streamgage network.

20. Information on streamgages in the East-Central Plains hydrologic region with significant leverage and influence in the Montana regional regression analyses .........84

21. Information on discontinued streamgages in the East-Central Plains hydrologic region that might be candidates for reactivation to improve the streamgage network.

22. Information on streamgages in the Southeast Plains hydrologic region with significant leverage and influence in the Montana regional regression analyses 
23. Information on discontinued streamgages in the Southeast Plains hydrologic region that might be candidates for reactivation to improve the streamgage network

24. Information on streamgages in the Upper Yellowstone-Central Mountain hydrologic region with significant leverage and influence in the Montana regional regression analyses

25. Information on discontinued streamgages in the Upper Yellowstone-Central Mountain hydrologic region that might be candidates for reactivation to improve the streamgage network

26. Information on streamgages in the Southwest hydrologic region with significant leverage and influence in the Montana regional regression analyses .......115

27. Information on discontinued streamgages in the Southwest hydrologic region that might be candidates for reactivation to improve the streamgage network

\section{Conversion Factors}

U.S. customary units to International System of Units

\begin{tabular}{|c|c|c|}
\hline Multiply & By & To obtain \\
\hline \multicolumn{3}{|c|}{ Length } \\
\hline inch (in.) & 2.54 & centimeter $(\mathrm{cm})$ \\
\hline inch (in.) & 25.4 & millimeter (mm) \\
\hline foot $(\mathrm{ft})$ & 0.3048 & meter $(\mathrm{m})$ \\
\hline mile (mi) & 1.609 & kilometer $(\mathrm{km})$ \\
\hline \multicolumn{3}{|c|}{ Area } \\
\hline square mile $\left(\mathrm{mi}^{2}\right)$ & 259.0 & hectare (ha) \\
\hline square mile $\left(\mathrm{mi}^{2}\right)$ & 2.590 & square kilometer $\left(\mathrm{km}^{2}\right)$ \\
\hline \multicolumn{3}{|c|}{ Flow rate } \\
\hline cubic foot per second $\left(\mathrm{ft}^{3} / \mathrm{s}\right)$ & 0.02832 & cubic meter per second $\left(\mathrm{m}^{3} / \mathrm{s}\right)$ \\
\hline
\end{tabular}

Temperature in degrees Fahrenheit $\left({ }^{\circ} \mathrm{F}\right)$ may be converted to degrees Celsius $\left({ }^{\circ} \mathrm{C}\right)$ as follows:

$$
{ }^{\circ} \mathrm{C}=\left({ }^{\circ} \mathrm{F}-32\right) / 1.8 \text {. }
$$

\section{Datum}

Vertical coordinate information is referenced to the North American Vertical Datum of 1988 (NAVD 88).

Horizontal coordinate information is referenced to the North American Datum of 1983 (NAD 83).

Elevation, as used in this report, refers to distance above the vertical datum.

\section{Supplemental Information}

Water year is the 12-month period from 0ctober 1 through September 30 of the following calendar year. The water year is designated by the calendar year in which it ends. For example, water year 2015 is the period from October 1, 2014, through September 30, 2015. 


\section{Abbreviations}

\begin{tabular}{|c|c|}
\hline$A B S$ & absolute value \\
\hline AEP & annual exceedance probability \\
\hline CDF & cumulative distribution function \\
\hline CONTDA & contributing drainage area \\
\hline CSG & crest-stage gage \\
\hline$E L_{5000}$ & percentage of basin above 5,000 feet elevation \\
\hline$E L_{6000}$ & percentage of basin above 6,000 feet elevation \\
\hline ET0306MOD & mean spring (March-June) evapotranspiration \\
\hline FOREST & percentage of basin that is forest \\
\hline LOWESS & locally weighted scatterplot smooths \\
\hline MDT & Montana Department of Transportation \\
\hline PFVI & peak-flow variability index \\
\hline PRECIP & mean annual precipitation \\
\hline RRE & regional regression equation \\
\hline SEP & mean standard error of prediction \\
\hline SLOP30_30M & percentage of basin with slope greater than 30 percent \\
\hline USGS & U.S. Geological Survey \\
\hline
\end{tabular}




\title{
Peak-Flow Variability, Peak-Flow Informational Needs, and Consideration of Regional Regression Analyses in Managing the Crest-Stage Gage Network in Montana
}

\author{
By Steven K. Sando
}

\section{Abstract}

The U.S. Geological Survey (USGS), in cooperation with the Montana Department of Transportation (MDT), has operated a crest-stage gage (CSG) network in Montana to collect peak-flow data since 1955 . The CSG network is vital to collecting peak-flow data on small drainage basins that typically are not addressed by continuous streamflow operations. Discussions between USGS and MDT identified a need for evaluating the CSG network to allow for better decision making in the management of the network. The purpose of this report is to (1) generally describe peak-flow variability in Montana, (2) assess peak-flow informational needs relevant to MDT activities, and (3) consider the characteristics of the active CSG network in relation to addressing the informational needs. The evaluation of the CSG network is intended to assist in prioritization for discontinuation of CSGs and other activities involving changes to the CSG network.

Peak-flow variability was investigated by analysis of selected peak-flow characteristics of 659 unregulated streamgages in or near Montana. A generalized peak-flow variability index $(P F V I)$ was developed to provide largescale representation of peak-flow variability in Montana. For unregulated Montana streamgages, PFVI generally monotonically decreases with increasing drainage area, although there is somewhat large (but generally consistent) variability about the locally weighted scatterplot smooth line. Presumably, highly variable small-scale hydroclimatic processes are integrated with increasing drainage area such that variability in many hydrologic characteristics is reduced. PFVI also decreases with increasing mean basin elevation and mean annual precipitation. Presumably, higher elevation and wetter hydroclimatic settings in Montana contribute to reduced variability in hydrologic characteristics. Intuitively, PFVI might be expected to generally decrease with increasing years of record because the standard deviation might typically be expected to decrease with increasing sample size. However, relations among PFVI and years of record are more complex and variable than drainage area, elevation, and precipitation. PFVI variably increases from 10 to about 40 years of record and then generally monotonically decreases from about 40 to about 105 years of record. Relations among PFVI and the years of record might be confounded by effects of drainage area because streamgages with long periods of record (greater than about 60 years) generally have large drainage areas (greater than about 100 square miles).

The relations between PFVI and drainage area, mean basin elevation, mean annual precipitation, and years of record substantially differ among the eight hydrologic regions in Montana. As such, the PFVI relations were further investigated within each hydrologic region.

A major use of peak-flow information by MDT is for design of road and highway infrastructure, including bridges, culverts, and roadside drainage ditches. As such, basin characteristics (including drainage area, mean basin elevation, and mean annual precipitation) of the Montana streamgage network (735 regulated and unregulated streamgages) were statistically investigated in relation to basin characteristics of 12,639 road and stream intersections in Montana. Both regulated and unregulated streamgages were investigated because the road and stream intersections are on both regulated and unregulated streams. Exploratory analyses indicated that the various relations substantially differ among the hydrologic regions. As such, the relations between the Montana streamgage network and the road and stream intersections were further investigated within each hydrologic region.

An important objective of the CSG network is to provide data for developing regional regression equations (RREs) for estimating frequencies at ungaged sites in Montana. Various characteristics of the RREs substantially differ among the eight hydrologic regions in Montana. As such, the RRE characteristics were further investigated within each hydrologic region.

For each of the eight hydrologic regions, various characteristics of peak-flow variability, peak-flow informational needs, and regional regression analyses were investigated in detail. Possible shortcomings of the streamgage network in each hydrologic region are identified and possible future improvements to the CSG network are presented. 


\section{Introduction}

The U.S. Geological Survey (USGS), in cooperation with the Montana Department of Transportation (MDT), has operated a crest-stage gage (CSG) network in Montana to collect peak-flow data since 1955. Description of CSG operations is provided in Sando and McCarthy (2018). Currently (2020) there are 88 CSGs being operated in Montana on drainage basins with areas ranging from 0.08 to 40.4 square miles $\left(\mathrm{mi}^{2}\right)$. The CSG network is vital to collecting peak-flow data on small drainage basins that typically are not addressed by continuous streamflow operations. For example, in eastern Montana (Northeast Plains, East-Central Plains, and Southeast Plains hydrologic regions) there are 29 active continuous streamgages and none are on drainage basins less than $110 \mathrm{mi}^{2}$ in area. However, within the three hydrologic regions, there are 63 CSGs and none are on drainage basins greater than $17 \mathrm{mi}^{2}$. Peak-flow data from the CSG network are essential to developing regional regression equations (RREs) for estimating peak-flow frequencies (hereinafter referred to as "frequencies") at ungaged sites in Montana. Without the CSG network, the RREs would not be valid for drainage areas less than about $100 \mathrm{mi}^{2}$. MDT and many other agencies and Tribes have continuing needs for peak-flow information for a large range of drainage basins, including small drainage basins.

The CSG network in Montana has fluctuated in size since its inception in 1955. The initial CSG network consisted of 45 CSGs but increased to 152 in 1959 and then to about 300 in the 1970s. Since the 1970s the CSG network generally decreased to the 88 active CSGs. The primary reason for the decrease in CSGs has been budgetary constraints. For about the past 10 years the funding for the network has remained constant while operational costs slowly have been increasing. Consequently, each year one or more CSGs have been discontinued. The selection of CSGs that are discontinued typically has been based on site-specific operational considerations. Sites that are more difficult and costly to accurately gage typically are prioritized for discontinuation. Generally, the peak-flow informational value of individual CSGs has not been strongly considered in prioritization for discontinuation.

Discussions between USGS and MDT identified a need for evaluating the CSG network to allow for better decision making in the management of the network. Investigation of peak-flow variability in Montana was considered an important part of the CSG network analysis because areas with high peak-flow variability might require dense peak-flow data collection to adequately describe peak-flow characteristics. Consideration of unregulated continuous streamgages also is an important part of the CSG network analysis because those streamgages contribute to the development of RREs. Future management of the CSG network might focus on improving the RREs by targeting hydroclimatic settings that are not well represented in the current (2020) combined CSG and unregulated continuous streamgage networks.

\section{Purpose and Scope}

The purpose of this report is to (1) generally describe peak-flow variability in Montana, (2) assess peak-flow informational needs relevant to MDT activities, and (3) consider the characteristics of the active CSG network in relation to addressing the informational needs. The evaluation of the CSG network is intended to assist in prioritization for discontinuation of CSGs and other activities involving changes to the CSG network.

\section{Description of Study Area}

The study area primarily consists of the State of Montana. Montana is a large State $\left(147,000 \mathrm{mi}^{2}\right)$ with large spatial variability in geologic, topographic, ecologic, and climatic characteristics; the large variability in these characteristics translates to large spatial variability in hydrologic regimes. Seven Level III ecoregions (U.S. Environmental Protection Agency, 2015) are represented in Montana (Canadian Rockies, Idaho Batholith, Middle Rockies, Northern Rockies, Northwestern Glaciated Plains, Northwestern Great Plains, and Wyoming Basin) with large variability in characteristics among the ecoregions. Somewhat abrupt transitions can exist among high-elevation mountains with intermontane valleys; welldrained, low-elevation plains; poorly drained, low-elevation glaciated prairies; and other complex geologic and hydroclimatic features.

Parrett and Johnson (2004) identified eight hydrologic regions in Montana to describe streamflow characteristics (fig. 1). Various topographic, climatic, and land-cover characteristics of the hydrologic regions are presented in table 1 . The percentages of each hydrologic region within each Level III ecoregion are presented in table 2.

Major drivers of peak-flow events in Montana include snowmelt, rainfall, and snowmelt with rainfall. Across Montana, large variability in climatic and topographic characteristics affects the spatial dominance among the major drivers and results in large variability in the flood regimes of streamgages. A brief overview of climatic and topographic characteristics relevant to Montana flood hydrology is presented by Sando and McCarthy (2018).

With an area of 147,000 $\mathrm{mi}^{2}$, Montana ranks fourth among States in the United States in size; however, Montana ranks 47th in population and 46th in tax base (U.S. Census Bureau, 2016). In conjunction with large variability in hydrologic regimes, the socioeconomic characteristics of Montana present substantial challenges for operating a large statewide streamgage network that consistently captures the hydrologic variability. 


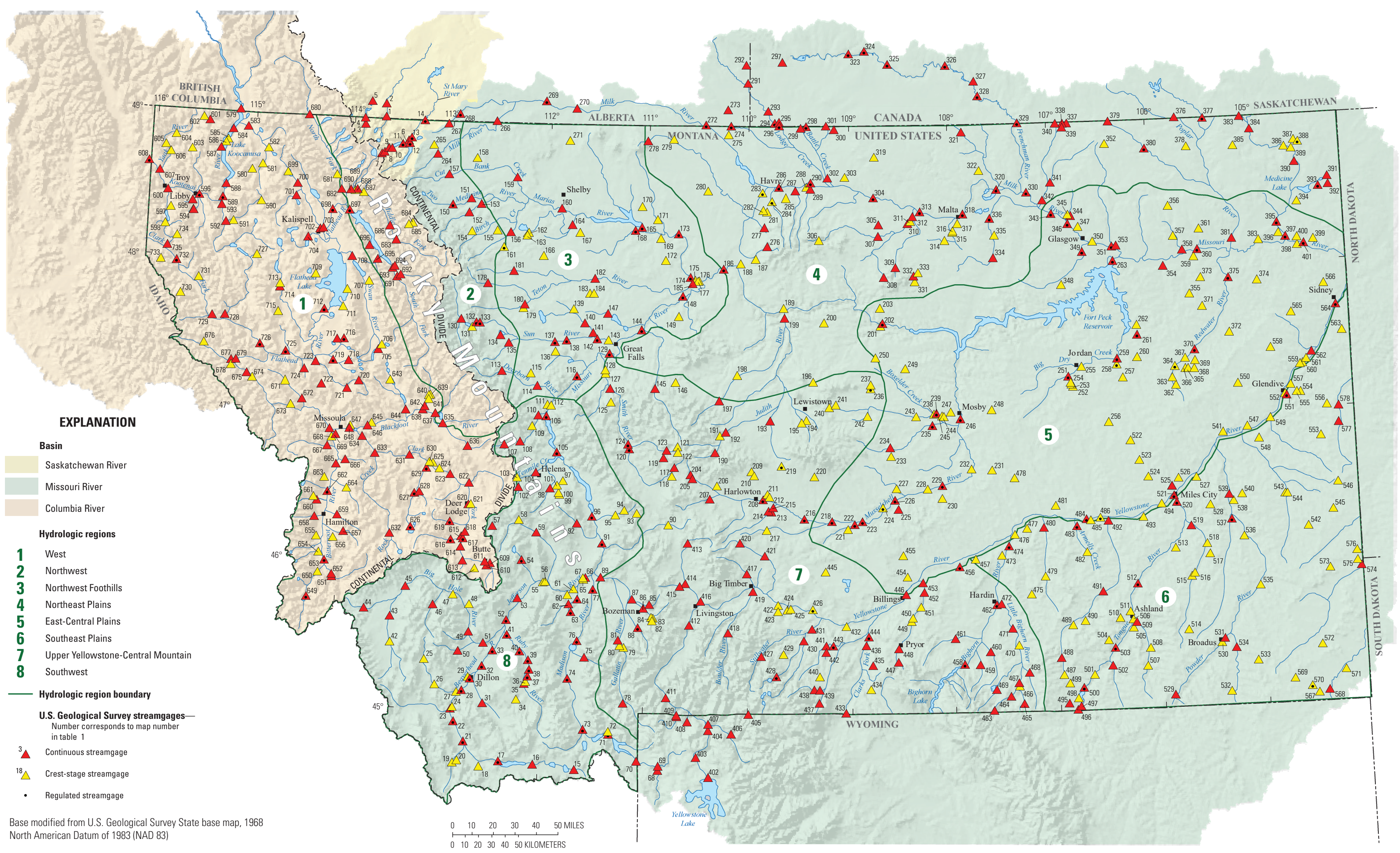

Figure 1. Locations of hydrologic regions (Sando, R., and others, 2018) and selected streamgages in or near Montana. 
Table 1. Geographic, climatic, and land-cover characteristics of hydrologic regions in Montana.

[HR, hydrologic region; No., number; $\mathrm{mi}^{2}$, square mile; elev., elevation; ft, foot; precip., precipitation; in., inch; LC, land cover; urb., urban; ag., agricultural; irr., irrigation; Jan., January; temp., air temperature; ${ }^{\circ} \mathrm{F}$, degrees Fahrenheit; gages, streamgages; mixed-pop. chars., mixed-population characteristics]

\begin{tabular}{|c|c|c|c|c|c|c|c|c|c|c|c|c|c|c|c|c|}
\hline HR & $\begin{array}{l}\text { HR No. } \\
\text { (fig. 1) }\end{array}$ & $\begin{array}{l}\text { Area, } \\
\text { in } \mathrm{mi}^{2}\end{array}$ & $\begin{array}{l}\text { Maximum } \\
\text { elev., } \\
\text { in } \mathrm{ft}^{1}\end{array}$ & $\begin{array}{l}\text { Minimum } \\
\text { elev., } \\
\text { in } \mathrm{ft}^{1}\end{array}$ & $\begin{array}{l}\text { Mean } \\
\text { elev., } \\
\text { in } \mathrm{ft}^{1}\end{array}$ & $\begin{array}{c}\begin{array}{c}\text { Percent } \\
\text { above }\end{array} \\
6,000 \mathrm{ft} \\
\text { elev. }^{1} \\
\end{array}$ & $\begin{array}{l}\text { Mean } \\
\text { slope }^{1,2}\end{array}$ & $\begin{array}{c}\text { Mean } \\
\text { annual } \\
\text { precip., } \\
\text { in in. }^{3} \\
\end{array}$ & $\begin{array}{c}\text { Percent } \\
\text { with } \\
\text { forest } \\
\text { LC } \\
\end{array}$ & $\begin{array}{l}\text { Percent } \\
\text { with } \\
\text { urb. LC }\end{array}$ & $\begin{array}{l}\text { Percent } \\
\text { with } \\
\text { ag. } \text { LC }^{4}\end{array}$ & $\begin{array}{l}\text { Percent } \\
\text { with } \\
\text { irr. }^{5}\end{array}$ & $\begin{array}{l}\text { Mean } \\
\text { Jan. } \\
\text { temp., } \\
\text { in }{ }^{\circ} \mathrm{F}^{3}\end{array}$ & $\begin{array}{l}\text { Mean } \\
\text { July } \\
\text { temp., } \\
\text { in }{ }^{\circ} \mathrm{F}^{3} \\
\end{array}$ & $\begin{array}{c}\text { Mean } \\
\text { annual } \\
\text { temp., } \\
\text { in }{ }^{\circ} \mathrm{F}^{3} \\
\end{array}$ & $\begin{array}{c}\text { Percent of } \\
\text { gages with } \\
\text { mixed-pop. } \\
\text { chars. }^{6}\end{array}$ \\
\hline West & 1 & 21,371 & 10,635 & 1,807 & 4,867 & 21.7 & 29.2 & 30.1 & 67.7 & 1.5 & 4.5 & 2.3 & 21.6 & 60.6 & 40.3 & 12.5 \\
\hline Northwest & 2 & 7,938 & 10,103 & 3,020 & 5,789 & 45.6 & 40.0 & 45.1 & 76.0 & 0.3 & 0.4 & 0.1 & 18.5 & 56.7 & 36.8 & 55.8 \\
\hline $\begin{array}{l}\text { Northwest } \\
\text { Foothills }\end{array}$ & 3 & 10,624 & 6,981 & 2,511 & 3,607 & 0.1 & 5.3 & 13.2 & 1.2 & 2.3 & 53.1 & 4.2 & 20.2 & 65.6 & 43.2 & 22.2 \\
\hline $\begin{array}{l}\text { Northeast } \\
\text { Plains }\end{array}$ & 4 & 22,059 & 7,666 & 1,922 & 2,928 & 0.1 & 6.4 & 13.5 & 2.2 & 1.6 & 34.0 & 1.1 & 15.1 & 67.6 & 42.5 & 1.4 \\
\hline $\begin{array}{l}\text { East-Central } \\
\text { Plains }\end{array}$ & 5 & 28,451 & 5,339 & 1,863 & 2,786 & 0.0 & 6.6 & 13.1 & 3.7 & 1.2 & 18.0 & 0.9 & 16.8 & 70.1 & 44.4 & 2.2 \\
\hline $\begin{array}{l}\text { Southeast } \\
\text { Plains }\end{array}$ & 6 & 18,520 & 5,353 & 1,880 & 3,189 & 0.0 & 9.9 & 14.7 & 9.8 & 0.7 & 4.8 & 0.8 & 18.7 & 70.7 & 44.9 & 0.0 \\
\hline $\begin{array}{l}\text { Upper } \\
\text { Yellowstone- } \\
\text { Central } \\
\text { Mountain }\end{array}$ & 7 & 23,003 & 12,763 & 2,809 & 5,432 & 29.4 & 18.8 & 21.2 & 21.6 & 1.4 & 10.2 & 3.4 & 21.6 & 64.2 & 42.0 & 3.9 \\
\hline Southwest & 8 & 14,891 & 11,268 & 3,389 & 6,376 & 61.0 & 20.5 & 19.8 & 34.8 & 1.6 & 5.4 & 3.4 & 19.4 & 60.2 & 38.7 & 17.2 \\
\hline
\end{tabular}

1Elevation and related variables were determined or calculated from the National Elevation Dataset (NED; Gesch and others, 2002). Elevation refers to distance above North American Vertical Datum of 1988 (NAVD 88).

${ }^{2}$ Mean slope was computed as the first derivative of the 30-meter elevation dataset.

3Precipitation and air temperature variables determined from climatic datasets obtained from Parameter-elevation Regression on Independent Slopes Model (PRISM) data (PRISM Climate Group, 2004). Mean annual precipitation and air temperature values were determined from 1971-2000 data.

${ }^{4}$ Land-cover variables were determined from the 2001 National Land Cover Dataset (NLCD; Homer and others, 2007).

${ }^{5}$ Irrigated area was determined from the Final Land Unit classification (FLU; Montana Department of Revenue, 2014) and represents the area under some type of irrigation regime.

${ }^{6}$ Criteria for designating streamgage peak-flow datasets as having mixed-population characteristics are described by Sando and McCarthy (2018). 
Table 2. Information on hydrologic regions and Level III ecoregions (U.S. Environmental Protection Agency, 2015) in Montana.

\begin{tabular}{|c|c|c|c|c|c|c|c|c|c|}
\hline \multirow[b]{2}{*}{$\begin{array}{l}\text { Hydrologic region (ordered clockwise from } \\
\text { northwestern Montana) }\end{array}$} & \multirow{2}{*}{$\begin{array}{l}\text { Hydrologic } \\
\text { region } \\
\text { number } \\
\text { (fig. 1) }\end{array}$} & \multirow{2}{*}{$\begin{array}{l}\text { Area, in } \\
\text { square } \\
\text { miles }\end{array}$} & \multicolumn{7}{|c|}{ Percentage of the hydrologic region within each Level III ecoregion ${ }^{1}$} \\
\hline & & & $\begin{array}{l}\text { Canadian } \\
\text { Rockies }\end{array}$ & $\begin{array}{l}\text { Idaho } \\
\text { Batholith }\end{array}$ & $\begin{array}{l}\text { Middle } \\
\text { Rockies }\end{array}$ & $\begin{array}{l}\text { Northern } \\
\text { Rockies }\end{array}$ & $\begin{array}{l}\text { Northwestern } \\
\text { Glaciated Plains }\end{array}$ & $\begin{array}{l}\text { Northwestern } \\
\text { Great Plains }\end{array}$ & $\begin{array}{l}\text { Wyoming } \\
\text { Basin }\end{array}$ \\
\hline West & 1 & 21,371 & 9.5 & 8.2 & 29.9 & 52.5 & 0.0 & 0.0 & 0.0 \\
\hline Northwest & 2 & 7,938 & 66.3 & 0.0 & 11.1 & 0.0 & 22.6 & 0.0 & 0.0 \\
\hline Northwest Foothills & 3 & 10,624 & 0.0 & 0.0 & 1.8 & 0.0 & 98.1 & 0.2 & 0.0 \\
\hline Northeast Plains & 4 & 22,059 & 0.0 & 0.0 & 2.2 & 0.0 & 81.2 & 16.6 & 0.0 \\
\hline East-Central Plains & 5 & 28,451 & 0.0 & 0.0 & 0.0 & 0.0 & 23.6 & 76.4 & 0.0 \\
\hline Southeast Plains & 6 & 18,520 & 0.0 & 0.0 & 0.0 & 0.0 & 0.0 & 100.0 & 0.0 \\
\hline Upper Yellowstone-Central Mountain & 7 & 23,003 & 0.0 & 0.0 & 35.8 & 0.0 & 0.1 & 62.2 & 1.9 \\
\hline Southwest & 8 & 14,891 & 0.0 & 1.8 & 95.5 & 0.0 & 0.8 & 1.9 & 0.0 \\
\hline
\end{tabular}

${ }^{1}$ The percentage of the hydrologic region within each Level III ecoregion was determined by geospatial analysis of the hydrologic regions (Sando, R., and others, 2018) and Level III ecoregions (U.S. Environmental Protection Agency, 2015) geospatial datasets. 


\section{Peak-Flow Variability in Montana}

Peak-flow variability was investigated by analysis of selected peak-flow characteristics of 659 unregulated streamgages in or near Montana. A generalized peak-flow variability index $(P F V I)$ was developed to provide large-scale representation of peak-flow variability in Montana. The PFVI is a version of the coefficient of variation and was calculated for each unregulated streamgage using the following equation:

$$
P F V I=100 X \operatorname{ABS}\left(\frac{\hat{\sigma}}{\hat{\mu}}\right)
$$

where

$$
\begin{array}{cl}
P F V I & \text { is the peak-flow variability index; } \\
A B S & \text { indicates absolute value; } \\
\hat{\sigma} & \text { is the standard deviation of the base-10 } \\
& \text { logarithms of peak flows as calculated } \\
& \text { using Bulletin 17 procedures } \\
& \text { (U.S. Interagency Advisory Committee } \\
& \text { on Water Data, 1982; England and others, } \\
& \text { 2019); and } \\
\hat{\mu} \quad \text { is the mean of the base-10 logarithms of } \\
\text { peak flows as calculated using Bulletin 17 } \\
\text { procedures (U.S. Interagency Advisory } \\
\text { Committee on Water Data, 1982; England } \\
\text { and others, 2019). }
\end{array}
$$

The generalized $P F V I$ is dimensionless and serves to normalize peak-flow variability among diverse streamgages. The primary purpose of the general $P F V I$ is to allow large-scale relative comparison of peak-flow variability among numerous diverse streamgages.

For 649 of the unregulated streamgages, the mean and standard deviations of the base-10 logarithms of peak flows were taken from frequency analyses by Sando and others (2016) and were calculated using Bulletin 17B procedures (U.S. Interagency Advisory Committee on Water Data, 1982) based on peak-flow data (U.S. Geological Survey, 2018) through water year 2011. Ten of the unregulated streamgages were CSGs that were not reported by Sando and others (2016) because they had less than 10 years of peak-flow data through water year 2011 but have greater than 10 years of peak-flow data through water year 2017. The mean and standard deviations of the 10 previously unreported CSGs were determined based on peak-flow data (U.S. Geological Survey, 2018) through water year 2017 using Bulletin 17C procedures (England and others, 2019) as described by Sando and McCarthy (2018). Differences between the mean and standard deviation calculation methods for the 649 streamgages reported by Sando and others (2016) and the 10 previously unreported CSGs are not considered to substantially affect the investigation of large-scale patterns in peak-flow variability.
The PFVI for each of the 659 streamgages was based on the length and period of record of that streamgage. Among the 659 streamgages, lengths of record varied from 10 to 105 years. The starting years in the periods of record for the 659 streamgages ranged from 1872 through 2003 and the ending years ranged from 1915 through 2017.

Statistical summaries of the PFVIs and other selected characteristics of the 659 unregulated streamgages are presented in table 3; summaries are presented for all 659 streamgages, 336 continuous streamgages, and 323 CSGs. Further, summaries are presented for the 231 active streamgages that are among the following categories: 143 active continuous streamgages and 88 active CSGs. Of the 659 unregulated streamgages in or near Montana, 15 of the streamgages are in Canada or Yellowstone National Park on streams that flow into Montana; those streamgages are considered to be representative of hydroclimatic characteristics of streams in Montana, but they are located outside of the Montana border and are not within the boundaries of the eight hydrologic regions. Thus, 644 unregulated streamgages are used in various analyses in this report that apply to unregulated streamgages within the eight hydrologic regions.

Several basin and streamgage characteristics, including contributing drainage area, mean basin elevation, mean annual precipitation, and the number of years of peak-flow records, might be factors that affect $P F V I$ and could be relevant to the management of the CSG network. Relations among PFVI and the selected characteristics for Montana streamgages are shown in figure 2 with distinction between CSGs and continuous streamgages. Locally weighted scatterplot smooths (LOWESS; Cleveland, 1985) are fitted through the relations between PFVI and drainage area (fig. 2A), mean basin elevation (fig. $2 B$ ), mean annual precipitation (fig. $2 C$ ), and years of peak-flow records relations (fig. $2 D$ ).

For unregulated Montana streamgages, PFVI generally monotonically decreases with increasing drainage area (fig. 2A), although there is somewhat large (but generally consistent) variability about the LOWESS line. Presumably, highly variable small-scale hydroclimatic processes are integrated with increasing drainage area such that variability in many hydrologic characteristics is reduced. PFVI also decreases with increasing mean basin elevation and mean annual precipitation (figs. $2 B$ and $2 C$ ). Presumably, higher elevation and wetter hydroclimatic settings in Montana contribute to reduced variability in hydrologic characteristics.

Presumably, PFVI might be expected to generally decrease with increasing years of record because the standard deviation might typically be expected to decrease with increasing sample size. However, relations between $P F V I$ and years of record (fig. $2 D$ ) are more complex and variable than drainage area, elevation, and precipitation. $P F V I$ variably increases from 10 to about 40 years of record, and then generally monotonically decreases from about 40 to about 105 years of record. 
Table 3. Statistical summaries of peak-flow variability indices and other selected characteristics of unregulated streamgages in or near Montana.

[For 649 streamgages, the standard deviations and means of the peak flows were calculated using Bulletin 17B procedures (U.S. Interagency Advisory Council on Water Data, 1982) for fitting the log-Pearson III distribution. For 10 streamgages, the standard deviations and means of the peak flows were calculated using Bulletin 17C procedures as described by Sando and McCarthy (2018) for fitting the log-Pearson III distribution. CONTDA, contributing drainage area, in square miles; $n$, number of years of unregulated peak-flow records; PFVI, peak-flow variability index calculated by 100 times the absolute value of the ratio of the standard deviation of the peak flows (base-10 logarithms) divided by the mean of the peak flows (base-10 logarithms); CSG, crest-stage gage; NA, not applicable; --, no data]

\begin{tabular}{|c|c|c|c|c|c|c|c|c|c|}
\hline \multirow{2}{*}{ Summary statistic } & \multicolumn{3}{|c|}{$\begin{array}{l}\text { All unregulated peak-flow } \\
\text { frequency streamgages }\end{array}$} & \multicolumn{3}{|c|}{$\begin{array}{c}\text { Continuous unregulated peak-flow } \\
\text { frequency streamgages }\end{array}$} & \multicolumn{3}{|c|}{$\begin{array}{l}\text { CSG unregulated peak-flow } \\
\text { frequency streamgages }\end{array}$} \\
\hline & CONTDA & $n$ & $P F V I^{1}$ & CONTDA & $n$ & PFVI ${ }^{1}$ & CONTDA & $n$ & PFVI ${ }^{1}$ \\
\hline \multicolumn{10}{|c|}{ Summary statistics for unregulated streamgages in or near Montana } \\
\hline NA & \multicolumn{3}{|c|}{659 streamgages summarized } & \multicolumn{3}{|c|}{336 streamgages summarized } & \multicolumn{3}{|c|}{323 streamgages summarized } \\
\hline Minimum & 0.08 & 10 & 1.35 & 0.64 & 10 & 1.35 & 0.08 & 10 & 2.32 \\
\hline 10th nonexceedance percentile & 1.42 & 12 & 4.22 & 31.05 & 11 & 3.30 & 0.78 & 15 & 10.24 \\
\hline 25th nonexceedance percentile & 4.52 & 16 & 7.74 & 78.80 & 15 & 4.96 & 1.84 & 16 & 21.67 \\
\hline Median & 37.30 & 23 & 18.26 & 259.00 & 26 & 8.32 & 4.52 & 20 & 38.09 \\
\hline Mean & $1,184.08$ & 30 & 58.51 & $2,295.75$ & 34 & 13.11 & 27.67 & 26 & 105.74 \\
\hline 75th nonexceedance percentile & 311.00 & 39 & 40.18 & 961.75 & 46 & 16.01 & 14.50 & 38 & 61.29 \\
\hline 90th nonexceedance percentile & $1,301.40$ & 56 & 72.06 & $4,830.00$ & 73 & 27.33 & 38.74 & 40 & 110.58 \\
\hline Maximum & $68,407.00$ & 105 & $5,900.00$ & $68,407.00$ & 105 & 165.78 & $1,223.00$ & 57 & $5,900.00$ \\
\hline \multicolumn{10}{|c|}{ Summary statistics for active unregulated streamgages in Montana } \\
\hline NA & \multicolumn{3}{|c|}{231 streamgages summarized } & \multicolumn{3}{|c|}{143 streamgages summarized } & \multicolumn{3}{|c|}{88 streamgages summarized } \\
\hline Minimum & 0.08 & 10 & 1.96 & 7.61 & 10 & 1.96 & 0.08 & 12 & 5.92 \\
\hline 10th nonexceedance percentile & 1.45 & 15 & 3.88 & 92.46 & 15 & 3.25 & 0.73 & 15 & 22.56 \\
\hline 25th nonexceedance percentile & 4.47 & 29 & 5.80 & 243.00 & 26 & 4.40 & 1.42 & 38 & 36.12 \\
\hline Median & 153.00 & 39 & 12.04 & 638.00 & 42 & 6.84 & 2.66 & 38 & 47.89 \\
\hline Mean & $2,586.84$ & 44 & 43.07 & $4,175.51$ & 49 & 10.02 & 5.26 & 38 & 96.77 \\
\hline 75th nonexceedance percentile & 998.00 & 57 & 42.37 & $2,494.00$ & 73 & 10.47 & 6.36 & 40 & 80.88 \\
\hline 90th nonexceedance percentile & $5,187.00$ & 79 & 78.46 & $11,094.40$ & 86 & 19.03 & 11.69 & 49 & 175.06 \\
\hline Maximum & $68,407.00$ & 105 & $1,126.98$ & $68,407.00$ & 105 & 73.77 & 40.40 & 57 & $1,126.98$ \\
\hline \multicolumn{10}{|c|}{ Summary statistics for unregulated streamgages in the West hydrologic region (hydrologic region 1, fig. 1) } \\
\hline NA & \multicolumn{3}{|c|}{133 streamgages summarized } & \multicolumn{3}{|c|}{80 streamgages summarized } & \multicolumn{3}{|c|}{53 streamgages summarized } \\
\hline Minimum & 0.60 & 10 & 1.35 & 6.86 & 10 & 1.35 & 0.60 & 10 & 2.32 \\
\hline 10th nonexceedance percentile & 4.56 & 11 & 3.47 & 21.62 & 10 & 3.01 & 2.53 & 11 & 4.46 \\
\hline 25th nonexceedance percentile & 10.10 & 15 & 4.93 & 56.20 & 17 & 4.25 & 4.52 & 14 & 7.17 \\
\hline Median & 52.00 & 21 & 7.63 & 277.00 & 28 & 6.42 & 8.07 & 18 & 14.01 \\
\hline Mean & 995.88 & 28 & 11.42 & $1,642.81$ & 34 & 8.00 & 19.39 & 20 & 16.60 \\
\hline 75th nonexceedance percentile & 383.00 & 33 & 12.92 & 917.00 & 41 & 8.65 & 22.60 & 22 & 23.53 \\
\hline
\end{tabular}


Table 3. Statistical summaries of peak-flow variability indices and other selected characteristics of unregulated streamgages in or near Montana.-Continued

[For 649 streamgages, the standard deviations and means of the peak flows were calculated using Bulletin 17B procedures (U.S. Interagency Advisory Council on Water Data, 1982) for fitting the log-Pearson III distribution. For 10 streamgages, the standard deviations and means of the peak flows were calculated using Bulletin $17 \mathrm{C}$ procedures as described by Sando and McCarthy (2018) for fitting the log-Pearson III distribution. CONTDA, contributing drainage area, in square miles; $n$, number of years of unregulated peak-flow records; $P F V I$, peak-flow variability index calculated by 100 times the absolute value of the ratio of the standard deviation of the peak flows (base-10 logarithms) divided by the mean of the peak flows (base-10 logarithms); CSG, crest-stage gage; NA, not applicable; --, no data]

\begin{tabular}{|c|c|c|c|c|c|c|c|c|c|}
\hline \multirow[t]{2}{*}{ Summary statistic } & \multicolumn{3}{|c|}{$\begin{array}{l}\text { All unregulated peak-flow } \\
\text { frequency streamgages }\end{array}$} & \multicolumn{3}{|c|}{$\begin{array}{l}\text { Continuous unregulated peak-flow } \\
\text { frequency streamgages }\end{array}$} & \multicolumn{3}{|c|}{$\begin{array}{l}\text { CSG unregulated peak-flow } \\
\text { frequency streamgages }\end{array}$} \\
\hline & CONTDA & $n$ & $P F V I^{1}$ & CONTDA & $n$ & $P F V I^{1}$ & CONTDA & $n$ & PFVI 1 \\
\hline \multicolumn{10}{|c|}{ Summary statistics for unregulated streamgages in the West hydrologic region (hydrologic region 1, fig. 1)—Continued } \\
\hline 90th nonexceedance percentile & $2,481.20$ & 61 & 23.80 & $6,126.80$ & 72 & 11.94 & 61.44 & 33 & 35.51 \\
\hline Maximum & $19,964.00$ & 96 & 84.69 & $19,964.00$ & 96 & 84.69 & 109.00 & 43 & 47.08 \\
\hline \multicolumn{10}{|c|}{ Summary statistics for active unregulated streamgages in the West hydrologic region (hydrologic region 1, fig. 1) } \\
\hline NA & \multicolumn{3}{|c|}{41 streamgages summarized } & \multicolumn{3}{|c|}{41 streamgages summarized } & \multicolumn{3}{|c|}{0 streamgages summarized } \\
\hline Minimum & 7.61 & 14 & 1.96 & 7.61 & 14 & 1.96 & -- & -- & -- \\
\hline 10th nonexceedance percentile & 70.50 & 23 & 3.44 & 70.50 & 23 & 3.44 & -- & -- & -- \\
\hline 25th nonexceedance percentile & 182.00 & 28 & 4.82 & 182.00 & 28 & 4.82 & -- & -- & -- \\
\hline Median & 498.00 & 37 & 6.34 & 498.00 & 37 & 6.34 & -- & -- & -- \\
\hline Mean & $2,011.19$ & 47 & 6.91 & $2,011.19$ & 47 & 6.91 & -- & -- & -- \\
\hline 75th nonexceedance percentile & $1,774.00$ & 71 & 8.41 & $1,774.00$ & 71 & 8.41 & -- & -- & -- \\
\hline 90th nonexceedance percentile & $6,021.00$ & 78 & 11.02 & $6,021.00$ & 78 & 11.02 & -- & -- & -- \\
\hline Maximum & $19,964.00$ & 96 & 20.69 & $19,964.00$ & 96 & 20.69 & -- & -- & -- \\
\hline \multicolumn{10}{|c|}{ Summary statistics for unregulated streamgages in Northwest hydrologic region (hydrologic region 2, fig. 1) } \\
\hline NA & \multicolumn{3}{|c|}{44 streamgages summarized } & \multicolumn{3}{|c|}{36 streamgages summarized } & \multicolumn{3}{|c|}{8 streamgages summarized } \\
\hline Minimum & 0.64 & 10 & 2.17 & 0.64 & 10 & 2.17 & 1.36 & 12 & 9.27 \\
\hline 10th nonexceedance percentile & 7.92 & 13 & 2.93 & 24.15 & 13 & 2.70 & 2.11 & 14 & 10.46 \\
\hline 25th nonexceedance percentile & 20.70 & 17 & 3.96 & 67.28 & 17 & 3.53 & 6.86 & 15 & 14.30 \\
\hline Median & 112.50 & 24 & 6.04 & 159.00 & 25 & 4.92 & 12.59 & 17 & 24.17 \\
\hline Mean & 284.95 & 31 & 11.56 & 345.59 & 33 & 6.73 & 12.06 & 20 & 33.29 \\
\hline 75th nonexceedance percentile & 286.25 & 40 & 11.76 & 420.75 & 44 & 8.12 & 18.60 & 25 & 32.84 \\
\hline 90th nonexceedance percentile & 952.80 & 65 & 21.79 & $1,041.00$ & 70 & 12.31 & 20.52 & 27 & 58.92 \\
\hline Maximum & $1,668.00$ & 99 & 115.41 & $1,668.00$ & 99 & 22.19 & 20.80 & 30 & 115.41 \\
\hline \multicolumn{10}{|c|}{ Summary statistics for active unregulated streamgages in Northwest hydrologic region (hydrologic region 2, fig. 1) } \\
\hline NA & \multicolumn{3}{|c|}{12 streamgages summarized } & \multicolumn{3}{|c|}{11 streamgages summarized } & \multicolumn{3}{|c|}{1 streamgages summarized } \\
\hline Minimum & 8.33 & 10 & 2.31 & 31.20 & 10 & 2.31 & 8.33 & 12 & 32.22 \\
\hline 10th nonexceedance percentile & 34.16 & 13 & 3.21 & 60.80 & 17 & 3.21 & -- & -- & -- \\
\hline 25th nonexceedance percentile & 97.70 & 28 & 3.29 & 131.50 & 36 & 3.27 & -- & -- & -- \\
\hline
\end{tabular}


Table 3. Statistical summaries of peak-flow variability indices and other selected characteristics of unregulated streamgages in or near Montana.-Continued

[For 649 streamgages, the standard deviations and means of the peak flows were calculated using Bulletin 17B procedures (U.S. Interagency Advisory Council on Water Data, 1982) for fitting the log-Pearson III distribution. For 10 streamgages, the standard deviations and means of the peak flows were calculated using Bulletin 17C procedures as described by Sando and McCarthy (2018) for fitting the log-Pearson III distribution. CONTDA, contributing drainage area, in square miles; $n$, number of years of unregulated peak-flow records; PFVI, peak-flow variability index calculated by 100 times the absolute value of the ratio of the standard deviation of the peak flows (base-10 logarithms) divided by the mean of the peak flows (base-10 logarithms); CSG, crest-stage gage; NA, not applicable; --, no data]

\begin{tabular}{|c|c|c|c|c|c|c|c|c|c|}
\hline \multirow[t]{2}{*}{ Summary statistic } & \multicolumn{3}{|c|}{$\begin{array}{l}\text { All unregulated peak-flow } \\
\text { frequency streamgages }\end{array}$} & \multicolumn{3}{|c|}{$\begin{array}{l}\text { Continuous unregulated peak-flow } \\
\text { frequency streamgages }\end{array}$} & \multicolumn{3}{|c|}{$\begin{array}{l}\text { CSG unregulated peak-flow } \\
\text { frequency streamgages }\end{array}$} \\
\hline & CONTDA & $n$ & PFVI 1 & CONTDA & $n$ & PFVI 1 & CONTDA & $n$ & PFVI 1 \\
\hline \multicolumn{10}{|c|}{ Summary statistics for active unregulated streamgages in Northwest hydrologic region (hydrologic region 2, fig. 1)—Continued } \\
\hline Median & 267.00 & 44 & 4.88 & 275.00 & 46 & 4.73 & -- & -- & -- \\
\hline Mean & 572.28 & 49 & 8.80 & 623.55 & 53 & 6.67 & -- & -- & -- \\
\hline 75th nonexceedance percentile & $1,133.50$ & 72 & 10.17 & $1,142.00$ & 73 & 7.66 & -- & -- & -- \\
\hline 90th nonexceedance percentile & $1,516.30$ & 88 & 19.19 & $1,556.00$ & 90 & 12.05 & -- & -- & -- \\
\hline Maximum & $1,668.00$ & 99 & 32.22 & $1,668.00$ & 99 & 19.98 & 8.33 & 12 & 32.22 \\
\hline \multicolumn{10}{|c|}{ Summary statistics for unregulated streamgages in the Northwest Foothills hydrologic region (hydrologic region 3, fig. 1) } \\
\hline NA & \multicolumn{3}{|c|}{40 streamgages summarized } & \multicolumn{3}{|c|}{18 streamgages summarized } & \multicolumn{3}{|c|}{22 streamgages summarized } \\
\hline Minimum & 0.19 & 11 & 3.59 & 55.80 & 11 & 3.59 & 0.19 & 13 & 21.83 \\
\hline 10th nonexceedance percentile & 0.69 & 13 & 8.97 & 114.33 & 12 & 5.81 & 0.23 & 15 & 25.75 \\
\hline 25th nonexceedance percentile & 2.93 & 16 & 14.76 & 259.25 & 14 & 9.02 & 0.92 & 16 & 39.18 \\
\hline Median & 20.85 & 20 & 27.17 & 526.50 & 29 & 12.63 & 3.39 & 18 & 46.54 \\
\hline Mean & $1,491.20$ & 30 & 37.52 & $3,304.38$ & 39 & 13.87 & 7.69 & 23 & 56.86 \\
\hline 75th nonexceedance percentile & 380.25 & 38 & 48.29 & $1,773.75$ & 59 & 16.75 & 13.58 & 29 & 71.45 \\
\hline 90th nonexceedance percentile & $1,981.60$ & 61 & 89.56 & $9,634.40$ & 77 & 22.58 & 20.02 & 38 & 92.39 \\
\hline Maximum & $24,297.00$ & 105 & 125.35 & $24,297.00$ & 105 & 34.15 & 31.40 & 52 & 125.35 \\
\hline
\end{tabular}

Summary statistics for active unregulated streamgages in the Northwest Foothills hydrologic region (hydrologic region 3, fig. 1)

NA

15 streamgages summarized

Minimum

10th nonexceedance percentile

25th nonexceedance percentile

Median

$\begin{array}{rrr}0.21 & 13 & 3.59 \\ 2.22 & 13 & 6.06 \\ 9.12 & 26 & 9.90 \\ 322.00 & 43 & 15.61 \\ 358.43 & 47 & 29.05 \\ 569.00 & 63 & 35.04 \\ 990.20 & 78 & 74.35 \\ 297.00 & 105 & 109.49\end{array}$

9 streamgages summarized

6 streamgages summarized

\begin{tabular}{|c|c|c|c|c|c|}
\hline \multicolumn{3}{|c|}{9 streamgages summarized } & \multicolumn{3}{|c|}{6 streamgages summarized } \\
\hline 256.00 & 13 & 3.59 & 0.21 & 13 & 21.88 \\
\hline 308.80 & 14 & 4.14 & 0.49 & 14 & 23.75 \\
\hline 405.00 & 43 & 8.74 & 1.68 & 20 & 30.33 \\
\hline $1,238.00$ & 60 & 9.91 & 5.03 & 38 & 45.84 \\
\hline $5,593.22$ & 57 & 10.51 & 6.25 & 32 & 56.85 \\
\hline $2,716.00$ & 75 & 14.82 & 10.86 & 38 & 81.14 \\
\hline $19,397.80$ & 85 & 15.92 & 13.25 & 45 & 100.97 \\
\hline $24,297.00$ & 105 & 17.12 & 13.90 & 52 & 109.49 \\
\hline
\end{tabular}


Table 3. Statistical summaries of peak-flow variability indices and other selected characteristics of unregulated streamgages in or near Montana.-Continued

[For 649 streamgages, the standard deviations and means of the peak flows were calculated using Bulletin 17B procedures (U.S. Interagency Advisory Council on Water Data, 1982) for fitting the log-Pearson III distribution. For 10 streamgages, the standard deviations and means of the peak flows were calculated using Bulletin 17C procedures as described by Sando and McCarthy (2018) for fitting the log-Pearson III distribution. CONTDA, contributing drainage area, in square miles; $n$, number of years of unregulated peak-flow records; PFVI, peak-flow variability index calculated by 100 times the absolute value of the ratio of the standard deviation of the peak flows (base-10 logarithms) divided by the mean of the peak flows (base-10 logarithms); CSG, crest-stage gage; NA, not applicable; --, no data]

\begin{tabular}{|c|c|c|c|c|c|c|c|c|c|}
\hline \multirow[t]{2}{*}{ Summary statistic } & \multicolumn{3}{|c|}{$\begin{array}{l}\text { All unregulated peak-flow } \\
\text { frequency streamgages }\end{array}$} & \multicolumn{3}{|c|}{$\begin{array}{l}\text { Continuous unregulated peak-flow } \\
\text { frequency streamgages }\end{array}$} & \multicolumn{3}{|c|}{$\begin{array}{l}\text { CSG unregulated peak-flow } \\
\text { frequency streamgages }\end{array}$} \\
\hline & CONTDA & $n$ & $P F V I^{1}$ & CONTDA & $n$ & PFVI 1 & CONTDA & $n$ & PFVI1 \\
\hline \multicolumn{10}{|c|}{ Summary statistics for unregulated streamgages in the Northeast Plains hydrologic region (hydrologic region 4, fig. 1) } \\
\hline NA & \multicolumn{3}{|c|}{76 streamgages summarized } & \multicolumn{3}{|c|}{42 streamgages summarized } & \multicolumn{3}{|c|}{34 streamgages summarized } \\
\hline Minimum & 0.08 & 10 & 3.67 & 2.11 & 10 & 3.67 & 0.08 & 11 & 15.00 \\
\hline 10th nonexceedance percentile & 1.66 & 12 & 13.33 & 13.56 & 10 & 11.34 & 0.80 & 14 & 30.25 \\
\hline 25th nonexceedance percentile & 3.22 & 16 & 20.69 & 68.98 & 14 & 17.62 & 1.76 & 18 & 34.87 \\
\hline Median & 31.85 & 29 & 32.05 & 181.50 & 24 & 22.68 & 3.02 & 30 & 51.05 \\
\hline Mean & 866.84 & 29 & 130.53 & $1,539.61$ & 30 & 28.19 & 35.76 & 29 & 256.94 \\
\hline 75th nonexceedance percentile & 248.25 & 39 & 54.40 & 643.50 & 44 & 31.20 & 6.50 & 38 & 88.39 \\
\hline 90th nonexceedance percentile & 934.50 & 47 & 105.05 & $1,466.50$ & 52 & 43.50 & 17.22 & 39 & 169.63 \\
\hline Maximum & $33,326.00$ & 80 & 5900.00 & $33,326.00$ & 80 & 165.78 & 850.00 & 52 & 5900.00 \\
\hline \multicolumn{10}{|c|}{ Summary statistics for active unregulated streamgages in the Northeast Plains hydrologic region (hydrologic region 4, fig. 1) } \\
\hline NA & \multicolumn{3}{|c|}{26 streamgages summarized } & \multicolumn{3}{|c|}{12 streamgages summarized } & \multicolumn{3}{|c|}{14 streamgages summarized } \\
\hline Minimum & 0.08 & 11 & 4.37 & 135.00 & 11 & 4.37 & 0.08 & 14 & 33.24 \\
\hline 10th nonexceedance percentile & 1.48 & 18 & 9.76 & 236.50 & 17 & 7.37 & 0.95 & 29 & 33.84 \\
\hline 25th nonexceedance percentile & 2.39 & 29 & 17.83 & 349.00 & 23 & 10.50 & 1.64 & 38 & 39.41 \\
\hline Median & 6.98 & 38 & 34.07 & $1,077.00$ & 35 & 17.68 & 2.40 & 38 & 70.69 \\
\hline Mean & $2,218.26$ & 36 & 79.11 & $4,803.08$ & 37 & 19.07 & 2.69 & 35 & 130.57 \\
\hline 75th nonexceedance percentile & 843.75 & 39 & 74.00 & $3,357.00$ & 44 & 22.37 & 2.68 & 38 & 120.39 \\
\hline 90th nonexceedance percentile & $3,967.00$ & 45 & 152.25 & $10,586.10$ & 63 & 32.21 & 4.66 & 39 & 301.90 \\
\hline Maximum & $33,326.00$ & 80 & 598.60 & $33,326.00$ & 80 & 48.20 & 8.90 & 39 & 598.60 \\
\hline \multicolumn{10}{|c|}{ Summary statistics for unregulated streamgages in the East-Central Plains hydrologic region (hydrologic region 5, fig. 1) } \\
\hline NA & \multicolumn{3}{|c|}{102 streamgages summarized } & \multicolumn{3}{|c|}{26 streamgages summarized } & \multicolumn{3}{|c|}{76 streamgages summarized } \\
\hline Minimum & 0.11 & 10 & 2.33 & 59.30 & 10 & 2.33 & 0.11 & 13 & 9.86 \\
\hline 10th nonexceedance percentile & 0.77 & 14 & 12.96 & 155.50 & 10 & 4.16 & 0.67 & 15 & 20.66 \\
\hline 25th nonexceedance percentile & 1.48 & 16 & 20.97 & 267.00 & 11 & 10.68 & 1.09 & 17 & 28.94 \\
\hline Median & 6.76 & 21 & 36.00 & 659.00 & 19 & 16.28 & 3.17 & 23 & 40.48 \\
\hline Mean & $2,644.41$ & 28 & 45.74 & $10,256.93$ & 25 & 20.42 & 40.13 & 28 & 54.40 \\
\hline 75th nonexceedance percentile & 211.75 & 38 & 49.61 & $3,035.25$ & 34 & 26.21 & 9.99 & 38 & 56.53 \\
\hline 90th nonexceedance percentile & $1,173.10$ & 49 & 73.59 & $43,710.50$ & 52 & 39.88 & 33.40 & 49 & 82.62 \\
\hline Maximum & $68,407.00$ & 74 & 396.25 & $68,407.00$ & 74 & 73.77 & $1,223.00$ & 54 & 396.25 \\
\hline
\end{tabular}


Table 3. Statistical summaries of peak-flow variability indices and other selected characteristics of unregulated streamgages in or near Montana.-Continued

[For 649 streamgages, the standard deviations and means of the peak flows were calculated using Bulletin 17B procedures (U.S. Interagency Advisory Council on Water Data, 1982) for fitting the log-Pearson III distribution. For 10 streamgages, the standard deviations and means of the peak flows were calculated using Bulletin 17C procedures as described by Sando and McCarthy (2018) for fitting the log-Pearson III distribution. CONTDA, contributing drainage area, in square miles; $n$, number of years of unregulated peak-flow records; PFVI, peak-flow variability index calculated by 100 times the absolute value of the ratio of the standard deviation of the peak flows (base-10 logarithms) divided by the mean of the peak flows (base-10 logarithms); CSG, crest-stage gage; NA, not applicable; --, no data]

\begin{tabular}{|c|c|c|c|c|c|c|c|c|c|}
\hline \multirow[t]{2}{*}{ Summary statistic } & \multicolumn{3}{|c|}{$\begin{array}{l}\text { All unregulated peak-flow } \\
\text { frequency streamgages }\end{array}$} & \multicolumn{3}{|c|}{$\begin{array}{l}\text { Continuous unregulated peak-flow } \\
\text { frequency streamgages }\end{array}$} & \multicolumn{3}{|c|}{$\begin{array}{l}\text { CSG unregulated peak-flow } \\
\text { frequency streamgages }\end{array}$} \\
\hline & CONTDA & $n$ & PFVI1 & CONTDA & $n$ & PFVII & CONTDA & $n$ & PFVI1 \\
\hline \multicolumn{10}{|c|}{ Summary statistics for active unregulated streamgages in the East-Central Plains hydrologic region (hydrologic region 5, fig. 1) } \\
\hline NA & \multicolumn{3}{|c|}{36 streamgages summarized } & \multicolumn{3}{|c|}{9 streamgages summarized } & \multicolumn{3}{|c|}{27 streamgages summarized } \\
\hline Minimum & 0.46 & 10 & 2.33 & 110.00 & 10 & 2.33 & 0.46 & 15 & 14.06 \\
\hline 10th nonexceedance percentile & 0.86 & 19 & 7.61 & 462.80 & 11 & 2.43 & 0.73 & 38 & 28.88 \\
\hline 25th nonexceedance percentile & 1.59 & 38 & 22.39 & 551.00 & 18 & 3.63 & 1.43 & 38 & 38.44 \\
\hline Median & 3.54 & 38 & 40.48 & $7,784.00$ & 23 & 10.52 & 2.30 & 38 & 42.94 \\
\hline Mean & $6,503.28$ & 38 & 62.21 & $26,002.22$ & 33 & 17.54 & 3.63 & 40 & 77.10 \\
\hline 75th nonexceedance percentile & 40.18 & 49 & 62.80 & $47,596.00$ & 50 & 19.17 & 4.13 & 45 & 68.39 \\
\hline 90th nonexceedance percentile & $23,804.50$ & 50 & 90.55 & $66,512.60$ & 57 & 33.01 & 8.11 & 49 & 126.63 \\
\hline Maximum & $68,407.00$ & 74 & 396.25 & $68,407.00$ & 74 & 73.77 & 16.90 & 54 & 396.25 \\
\hline \multicolumn{10}{|c|}{ Summary statistics for unregulated streamgages in the Southeast Plains hydrologic region (hydrologic region 6, fig. 1) } \\
\hline NA & \multicolumn{3}{|c|}{74 streamgages summarized } & \multicolumn{3}{|c|}{20 streamgages summarized } & \multicolumn{3}{|c|}{54 streamgages summarized } \\
\hline Minimum & 0.10 & 10 & 4.19 & 3.91 & 10 & 4.19 & 0.10 & 11 & 9.57 \\
\hline 10th nonexceedance percentile & 0.82 & 15 & 10.11 & 114.99 & 11 & 7.37 & 0.71 & 15 & 18.37 \\
\hline 25th nonexceedance percentile & 1.99 & 16 & 19.70 & 434.50 & 18 & 9.30 & 1.47 & 16 & 27.84 \\
\hline Median & 7.14 & 30 & 35.21 & 852.50 & 27 & 17.09 & 3.57 & 30 & 44.05 \\
\hline Mean & 887.54 & 30 & 55.72 & $3,226.24$ & 32 & 19.68 & 21.36 & 30 & 69.07 \\
\hline 75th nonexceedance percentile & 123.50 & 39 & 60.34 & $1,687.50$ & 43 & 27.20 & 9.91 & 39 & 74.98 \\
\hline 90th nonexceedance percentile & $1,244.00$ & 49 & 95.45 & $9,103.60$ & 55 & 36.55 & 19.45 & 40 & 102.92 \\
\hline Maximum & $22,419.00$ & 82 & 646.46 & $22,419.00$ & 82 & 48.84 & 663.00 & 57 & 646.46 \\
\hline \multicolumn{10}{|c|}{ Summary statistics for active unregulated streamgages in the Southeast Plains hydrologic region (hydrologic region 6, fig. 1) } \\
\hline NA & \multicolumn{3}{|c|}{30 streamgages summarized } & \multicolumn{3}{|c|}{8 streamgages summarized } & \multicolumn{3}{|c|}{22 streamgages summarized } \\
\hline Minimum & 0.13 & 20 & 4.19 & 124.00 & 20 & 4.19 & 0.13 & 38 & 18.26 \\
\hline 10th nonexceedance percentile & 0.78 & 29 & 9.75 & 364.10 & 21 & 6.52 & 0.53 & 38 & 31.29 \\
\hline 25th nonexceedance percentile & 1.73 & 38 & 29.46 & 638.75 & 27 & 8.75 & 1.36 & 39 & 40.51 \\
\hline Median & 4.28 & 39 & 47.00 & $1,080.50$ & 31 & 14.74 & 2.68 & 39 & 49.89 \\
\hline
\end{tabular}


[For 649 streamgages, the standard deviations and means of the peak flows were calculated using Bulletin 17B procedures (U.S. Interagency Advisory Council on Water Data, 1982) for fitting the log-Pearson III distribution. For 10 streamgages, the standard deviations and means of the peak flows were calculated using Bulletin 17C procedures as described by Sando and McCarthy (2018) for fitting the log-Pearson III distribution. CONTDA, contributing drainage area, in square miles; $n$, number of years of unregulated peak-flow records; PFVI, peak-flow variability index calculated by 100 times the absolute value of the ratio of the standard deviation of the peak flows (base-10 logarithms) divided by the mean of the peak flows (base-10 logarithms); CSG, crest-stage gage; NA, not applicable; --, no data]

\begin{tabular}{|c|c|c|c|c|c|c|c|c|c|}
\hline \multirow[t]{2}{*}{ Summary statistic } & \multicolumn{3}{|c|}{$\begin{array}{l}\text { All unregulated peak-flow } \\
\text { frequency streamgages }\end{array}$} & \multicolumn{3}{|c|}{$\begin{array}{c}\text { Continuous unregulated peak-flow } \\
\text { frequency streamgages }\end{array}$} & \multicolumn{3}{|c|}{$\begin{array}{l}\text { CSG unregulated peak-flow } \\
\text { frequency streamgages }\end{array}$} \\
\hline & CONTDA & $n$ & PFVI1 & CONTDA & $n$ & PFVI1 & CONTDA & $n$ & PFVI 1 \\
\hline \multicolumn{10}{|c|}{ Summary statistics for active unregulated streamgages in the Southeast Plains hydrologic region (hydrologic region 6, fig. 1)—Continued } \\
\hline Mean & $1,568.06$ & 41 & 72.01 & $5,869.50$ & 42 & 20.26 & 3.90 & 41 & 90.83 \\
\hline 75th nonexceedance percentile & 95.90 & 40 & 74.40 & $1,443.59$ & 32 & 19.56 & 5.72 & 40 & 85.51 \\
\hline 90th nonexceedance percentile & $2,108.80$ & 52 & 98.28 & $15,867.70$ & 76 & 39.90 & 8.52 & 49 & 103.62 \\
\hline Maximum & $22,419.00$ & 82 & 646.46 & $22,419.00$ & 82 & 48.84 & 11.60 & 57 & 646.46 \\
\hline \multicolumn{10}{|c|}{ Summary statistics for unregulated streamgages in the Upper Yellowstone-Central Mountain hydrologic region (hydrologic region 7, fig. 1) } \\
\hline NA & \multicolumn{3}{|c|}{108 streamgages summarized } & \multicolumn{3}{|c|}{64 streamgages summarized } & \multicolumn{3}{|c|}{44 streamgages summarized } \\
\hline Minimum & 0.39 & 10 & 1.89 & 7.23 & 10 & 1.89 & 0.39 & 11 & 8.00 \\
\hline 10th nonexceedance percentile & 2.49 & 13 & 3.51 & 47.66 & 12 & 2.98 & 1.25 & 15 & 13.02 \\
\hline 25th nonexceedance percentile & 7.37 & 16 & 7.75 & 64.63 & 18 & 5.20 & 2.49 & 15 & 23.02 \\
\hline Median & 56.35 & 27 & 14.48 & 157.00 & 31 & 8.05 & 5.44 & 19 & 42.53 \\
\hline Mean & 737.13 & 35 & 94.01 & $1,227.78$ & 41 & 10.34 & 23.48 & 26 & 215.70 \\
\hline 75th nonexceedance percentile & 226.25 & 46 & 33.48 & 547.75 & 63 & 13.58 & 18.48 & 38 & 61.01 \\
\hline 90th nonexceedance percentile & $1,121.20$ & 75 & 61.09 & $1,728.70$ & 87 & 18.97 & 45.68 & 47 & 231.89 \\
\hline Maximum & $20,718.00$ & 105 & $5,652.38$ & $20,718.00$ & 105 & 40.78 & 430.00 & 57 & $5,652.38$ \\
\hline \multicolumn{10}{|c|}{ Summary statistics for active unregulated streamgages in the Upper Yellowstone-Central Mountain hydrologic region (hydrologic region 7, fig. 1) } \\
\hline NA & \multicolumn{3}{|c|}{35 streamgages summarized } & \multicolumn{3}{|c|}{25 streamgages summarized } & \multicolumn{3}{|c|}{10 streamgages summarized } \\
\hline Minimum & 0.39 & 10 & 2.71 & 48.50 & 10 & 2.71 & 0.39 & 15 & 15.13 \\
\hline 10th nonexceedance percentile & 3.23 & 20 & 2.93 & 71.52 & 24 & 2.80 & 1.16 & 15 & 19.99 \\
\hline 25th nonexceedance percentile & 25.65 & 36 & 4.24 & 198.00 & 33 & 3.29 & 1.58 & 38 & 23.47 \\
\hline Median & 230.00 & 53 & 7.16 & 819.00 & 73 & 6.14 & 4.76 & 38 & 40.42 \\
\hline Mean & $1,476.15$ & 56 & 56.06 & $2,063.37$ & 64 & 6.49 & 8.11 & 38 & 180.00 \\
\hline 75th nonexceedance percentile & $1,130.00$ & 80 & 18.27 & $1,588.00$ & 87 & 7.68 & 8.11 & 48 & 60.62 \\
\hline 90th nonexceedance percentile & $2,383.20$ & 96 & 52.17 & $3,177.00$ & 98 & 11.76 & 13.85 & 53 & 463.40 \\
\hline Maximum & $19,672.00$ & 105 & $1,126.98$ & $19,672.00$ & 105 & 16.02 & 40.40 & 57 & $1,126.98$ \\
\hline
\end{tabular}


Table 3. Statistical summaries of peak-flow variability indices and other selected characteristics of unregulated streamgages in or near Montana.-Continued

[For 649 streamgages, the standard deviations and means of the peak flows were calculated using Bulletin 17B procedures (U.S. Interagency Advisory Council on Water Data, 1982) for fitting the log-Pearson III distribution. For 10 streamgages, the standard deviations and means of the peak flows were calculated using Bulletin 17C procedures as described by Sando and McCarthy (2018) for fitting the log-Pearson III distribution. CONTDA, contributing drainage area, in square miles; $n$, number of years of unregulated peak-flow records; PFVI, peak-flow variability index calculated by 100 times the absolute value of the ratio of the standard deviation of the peak flows (base-10 logarithms) divided by the mean of the peak flows (base-10 logarithms); CSG, crest-stage gage; NA, not applicable; --, no data]

\begin{tabular}{|c|c|c|c|c|c|c|c|c|c|}
\hline \multirow[t]{2}{*}{ Summary statistic } & \multicolumn{3}{|c|}{$\begin{array}{l}\text { All unregulated peak-flow } \\
\text { frequency streamgages }\end{array}$} & \multicolumn{3}{|c|}{$\begin{array}{l}\text { Continuous unregulated peak-flow } \\
\text { frequency streamgages }\end{array}$} & \multicolumn{3}{|c|}{$\begin{array}{l}\text { CSG unregulated peak-flow } \\
\text { frequency streamgages }\end{array}$} \\
\hline & CONTDA & $n$ & PFVI 1 & CONTDA & $n$ & PFVI1 & CONTDA & $n$ & $P F V I^{1}$ \\
\hline \multicolumn{10}{|c|}{ Summary statistics for unregulated streamgages in the Southwest hydrologic region (hydrologic region 8, fig. 1) } \\
\hline NA & \multicolumn{3}{|c|}{67 streamgages summarized } & \multicolumn{3}{|c|}{35 streamgages summarized } & \multicolumn{3}{|c|}{32 streamgages summarized } \\
\hline Minimum & 0.42 & 11 & 2.88 & 22.80 & 11 & 2.88 & 0.42 & 14 & 5.92 \\
\hline 10th nonexceedance percentile & 3.55 & 14 & 4.75 & 36.34 & 12 & 4.06 & 1.23 & 15 & 9.17 \\
\hline 25th nonexceedance percentile & 11.45 & 15 & 6.49 & 75.25 & 15 & 5.19 & 3.73 & 16 & 17.90 \\
\hline Median & 44.60 & 19 & 9.30 & 316.00 & 24 & 6.74 & 10.17 & 18 & 35.34 \\
\hline Mean & $1,235.29$ & 30 & 88.22 & $2,330.66$ & 35 & 7.02 & 37.22 & 25 & 177.04 \\
\hline 75th nonexceedance percentile & 334.50 & 38 & 32.60 & $1,873.50$ & 43 & 8.68 & 31.20 & 38 & 99.98 \\
\hline 90th nonexceedance percentile & $2,692.80$ & 71 & 123.12 & $8,781.20$ & 77 & 9.33 & 79.75 & 40 & 174.27 \\
\hline Maximum & $16,669.00$ & 95 & $2,898.55$ & $16,669.00$ & 95 & 14.49 & 348.00 & 54 & $2,898.55$ \\
\hline \multicolumn{10}{|c|}{ Summary statistics for active unregulated streamgages in the Southwest hydrologic region (hydrologic region 8, fig. 1) } \\
\hline NA & \multicolumn{3}{|c|}{29 streamgages summarized } & \multicolumn{3}{|c|}{21 streamgages summarized } & \multicolumn{3}{|c|}{8 streamgages summarized } \\
\hline Minimum & 1.37 & 14 & 3.91 & 33.00 & 14 & 3.91 & 1.37 & 14 & 5.92 \\
\hline 10th nonexceedance percentile & 10.62 & 14 & 4.93 & 85.90 & 15 & 4.43 & 2.95 & 14 & 7.24 \\
\hline 25th nonexceedance percentile & 30.50 & 15 & 5.89 & 192.00 & 22 & 5.79 & 5.02 & 14 & 21.79 \\
\hline Median & 381.00 & 36 & 7.22 & 566.00 & 34 & 6.74 & 13.10 & 38 & 46.27 \\
\hline Mean & $2,235.41$ & 41 & 20.11 & $3,081.52$ & 45 & 7.07 & 14.36 & 31 & 54.35 \\
\hline 75th nonexceedance percentile & $2,472.00$ & 71 & 9.31 & $2,730.00$ & 73 & 8.35 & 20.58 & 39 & 59.22 \\
\hline 90th nonexceedance percentile & $8,004.40$ & 80 & 51.39 & $9,558.00$ & 85 & 9.30 & 30.43 & 43 & 103.22 \\
\hline Maximum & $16,669.00$ & 95 & 174.75 & $16,669.00$ & 95 & 14.49 & 30.50 & 52 & 174.75 \\
\hline
\end{tabular}

${ }^{1}$ The peak-flow variability index for each streamgage summarized was based on the length and period of record of that streamgage. Among the 659 streamgages summarized, the starting years in the periods of record ranged from 1872 through 2003 and the ending years ranged from 1915 through 2017. 

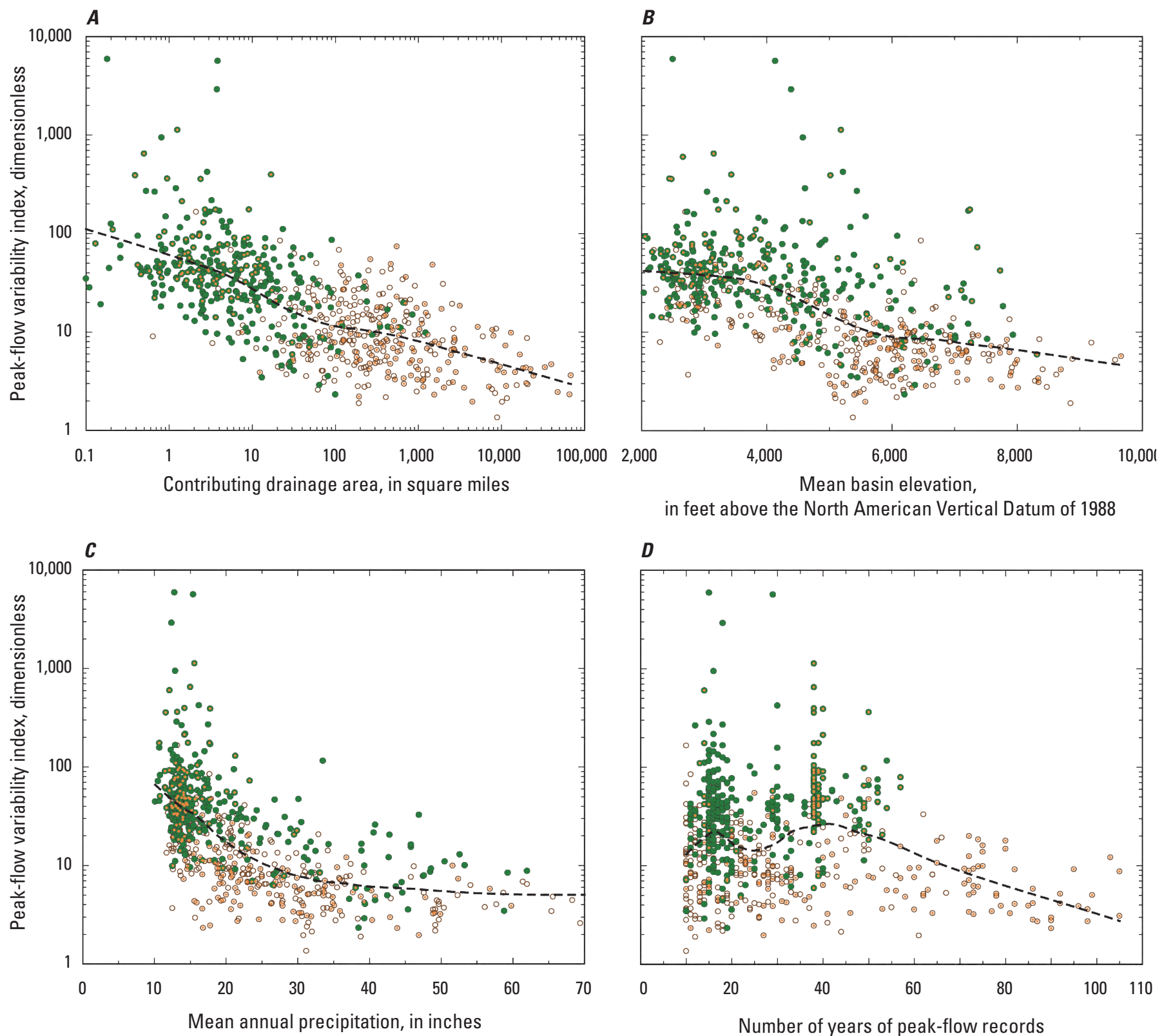

in feet above the North American Vertical Datum of 1988

D

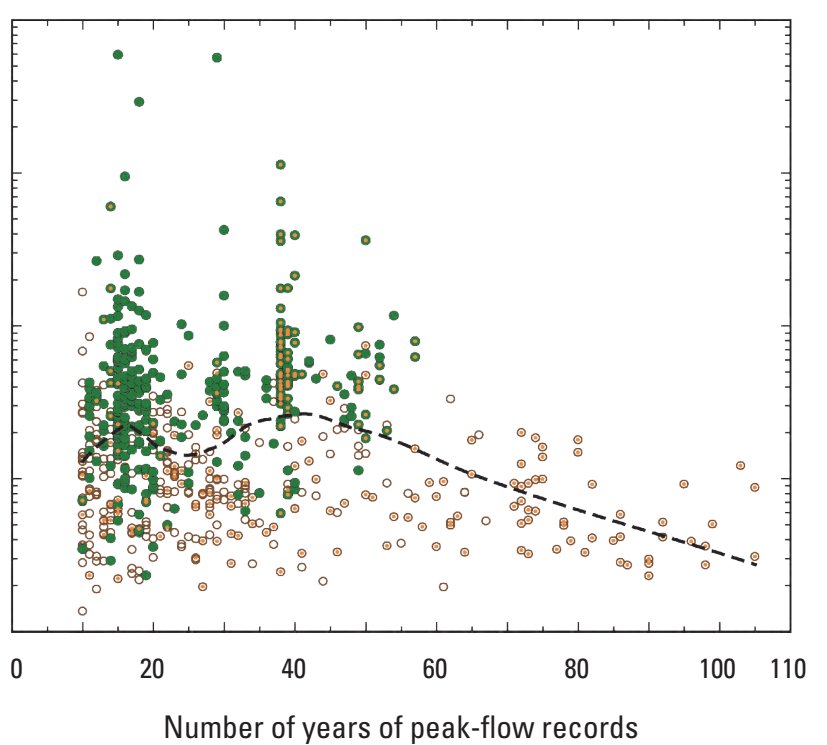

EXPLANATION

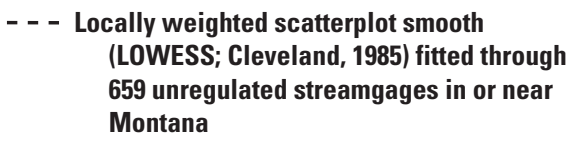

- Crest-stage streamgage

- Continuous streamgage

- Interior dot denotes active streamgage in water year 2017

Figure 2. Relations between peak-flow variability index and selected drainage-basin and streamgage characteristics for 659 unregulated streamgages in or near Montana. $A$, Peak-flow variability and contributing drainage area relations. $B$, Peak-flow variability and mean basin elevation relations. $C$, Peak-flow variability and mean annual precipitation relations. $D$, Peak-flow variability and years of peak-flow records relations. 
Relations among PFVI and the selected characteristics shown in figure 2 might be confounded by relations among drainage area and the other characteristics (fig. 3). Of particular note, streamgages with long periods of record (greater than about 60 years) generally have large drainage areas (greater than about $100 \mathrm{mi}^{2}$ ) as shown in figure $3 C$. Thus, general relations between $P F V I$ and years of record are difficult to characterize when all 659 unregulated streamgages are evaluated on a statewide basis; better understanding of the relations might be achieved by evaluation within each hydrologic region. The hydrologic region of each streamgage is not indicated in figure 2, but LOWESS lines fitted through the streamgage data of each hydrologic region are shown in figure 4 to assist in evaluation of the various relations within each hydrologic region.

LOWESS lines fitted through various relations between $P F V I$ and the selected characteristics for each hydrologic region in Montana are shown in figure 4. The LOWESS lines in figure 4 are sometimes difficult to distinguish among the hydrologic regions and are sometimes confusing, but the primary purpose of figure 4 is to initially establish that the various relations have some general similarities but also substantially differ among hydrologic regions. For example, the LOWESS lines through the relations between PFVI and drainage area (fig. $4 A$ ) and years of record (fig. $4 D$ ) for the West and Northwest hydrologic regions are consistently below the LOWESS line through the data for all unregulated streamgages in Montana. The West and Northwest hydrologic regions have much lower median $P F V I$ values (7.63 and 6.04 , respectively; table 3 ) than the median for all unregulated streamgages in Montana (18.26, table 3). In contrast, the LOWESS lines through the relations between PFVI and drainage area (fig. $4 A$ ) and years of record (fig. $4 D$ ) for the Northeast Plains, East-Central Plains, and Southeast Plains hydrologic regions generally are above the LOWESS line through the data for all unregulated streamgages in Montana. The Northeast Plains, East-Central Plains, and Southeast Plains hydrologic regions have much higher median PFVI values $(32.05,36.00$, and 35.21 , respectively; table 3$)$ than the median for all unregulated streamgages in Montana (18.26, table 3). The substantial differences in the various relations among the hydrologic regions provide evidence of the need to consider each hydrologic region independently when evaluating peak-flow variability and peak-flow informational needs. As such, these subjects are addressed for each hydrologic region in the section "Description of Peak-Flow Variability and Peak-Flow Informational Needs, and Consideration of Regional Regression Analyses by Hydrologic Region."

In the previous paragraph and in various other sections of this report, the median PFVI is used as a single metric to make general comparisons of peak-flow variability among the hydrologic regions. It should be noted that this usage of the median PFVI is imprecise because the PFVI is affected by many factors (notably contributing drainage area and years of record) that vary in their representation within each hydrologic region. However, figures $4 A$ and $4 D$ show that the LOWESS lines for hydrologic regions with the lowest median PFVI values (the West and Northwest hydrologic regions) generally are below the LOWESS line for all unregulated streamgages in Montana throughout their full ranges in contributing drainage area (fig. $4 A$ ) and years of record (fig. 4D). Likewise, the LOWESS lines for hydrologic regions with the highest median $P F V I$ values (the Northeast Plains, East-Central Plains, and Southeast Plains hydrologic regions) generally are above the LOWESS line for all unregulated streamgages in Montana throughout their full ranges in contributing drainage area (fig. $4 A$ ) and years of record (fig. $4 D$ ). Intuitively, the median $P F V I$ values of the hydrologic regions would reasonably capture the relative variability in peak-flow variability among the hydrologic regions. However, given the complex interactions of various factors affecting the $P F V I$ values and the acknowledged imprecision of the median $P F V I$ value as a single metric, some other single metric might result in small differences in the relative ranking of peak-flow variability among the hydrologic regions. 


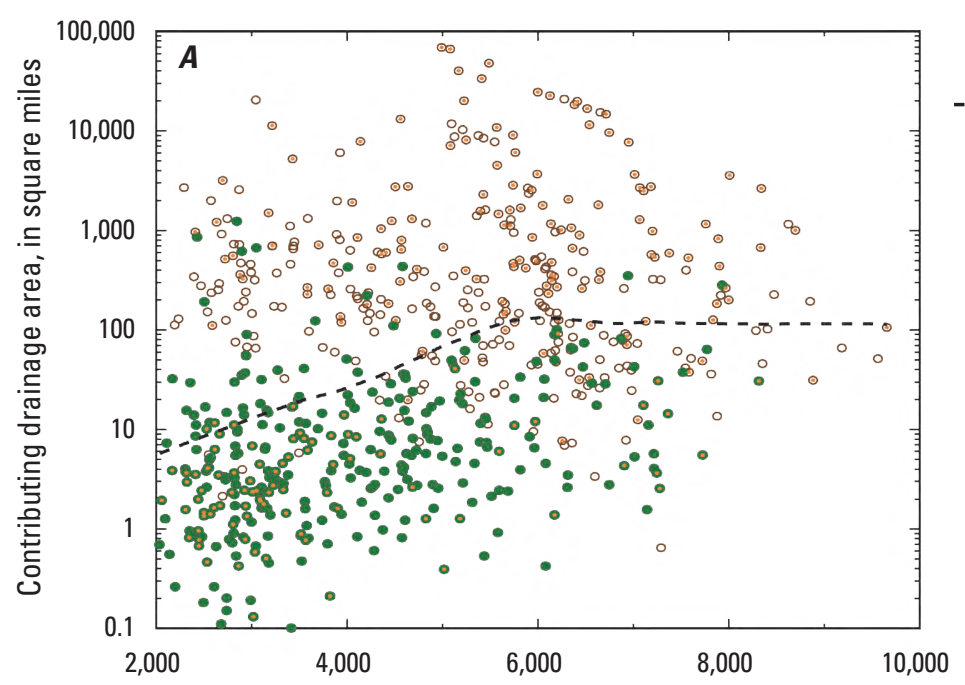

\section{EXPLANATION}

- - - Locally weighted scatterplot smooth (LOWESS; Cleveland, 1985) fitted through 659 unregulated streamgages in or near Montana

- Crest-stage streamgage

- Continuous streamgage

Interior dot denotes active streamgage in water year 2017

Mean basin elevation, in feet above the North American Vertical Datum of 1988
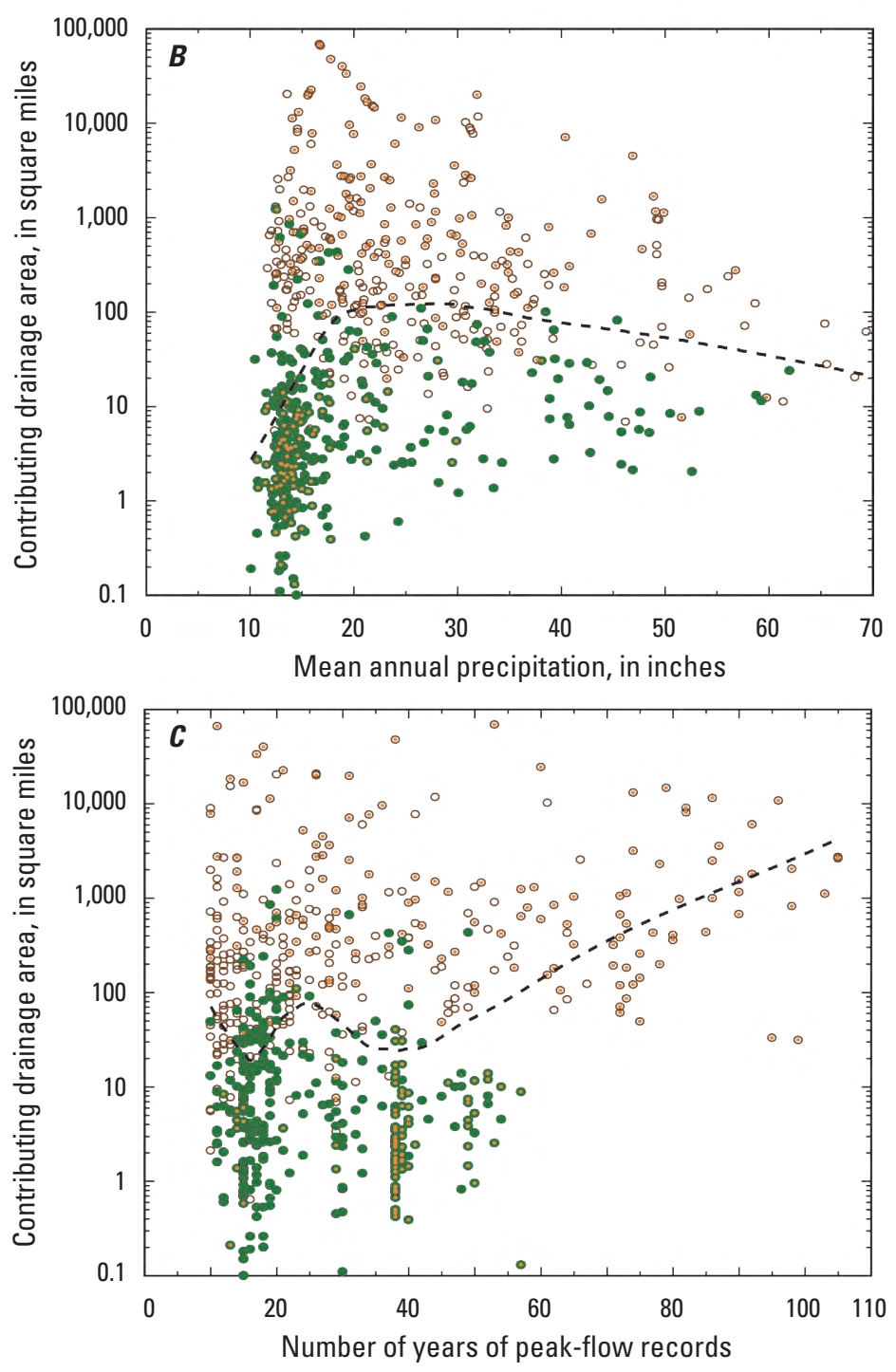

Figure 3. Relations between contributing drainage area and mean basin elevation, mean annual precipitation, and years of peak-flow records for 659 unregulated streamgages in or near Montana. $A$, Contributing drainage area and mean basin elevation relations. $B$, Contributing drainage area and mean annual precipitation relations. $C$, Contributing drainage area and years of peak-flow records relations. 

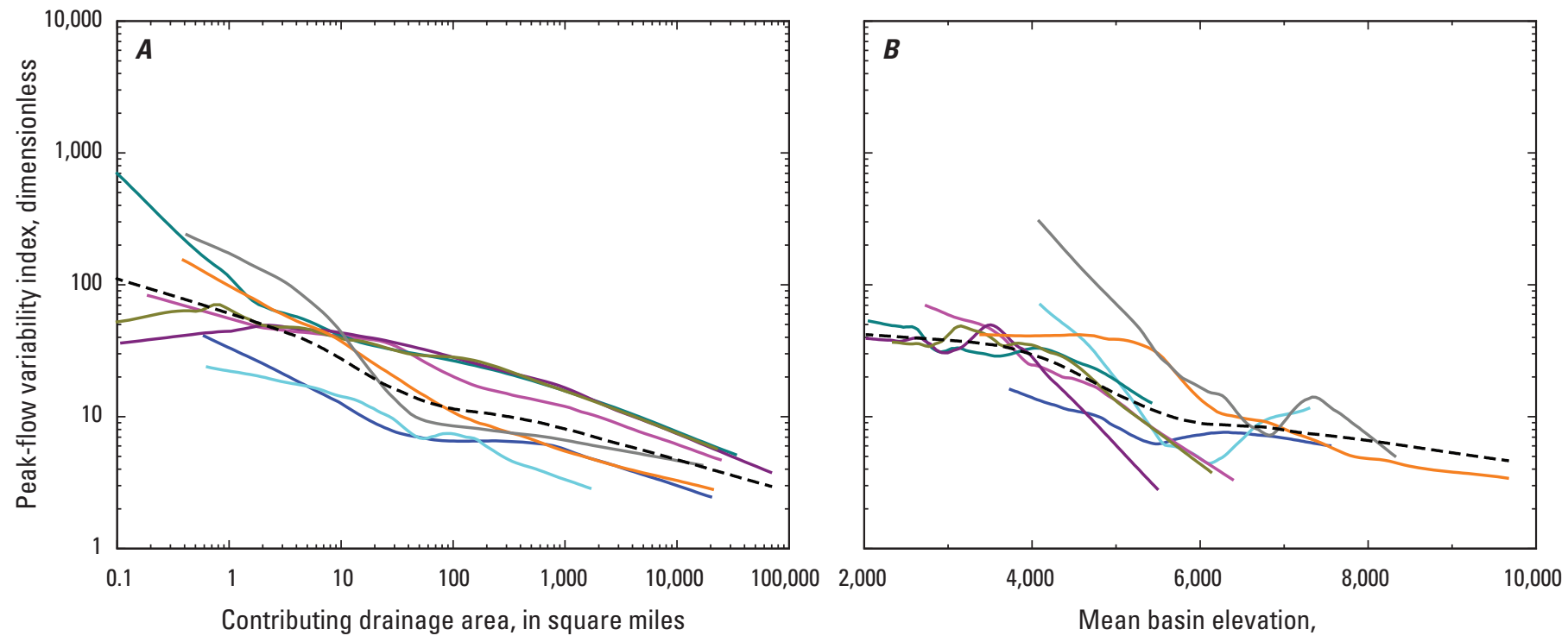

in feet above the North American Vertical Datum of 1988
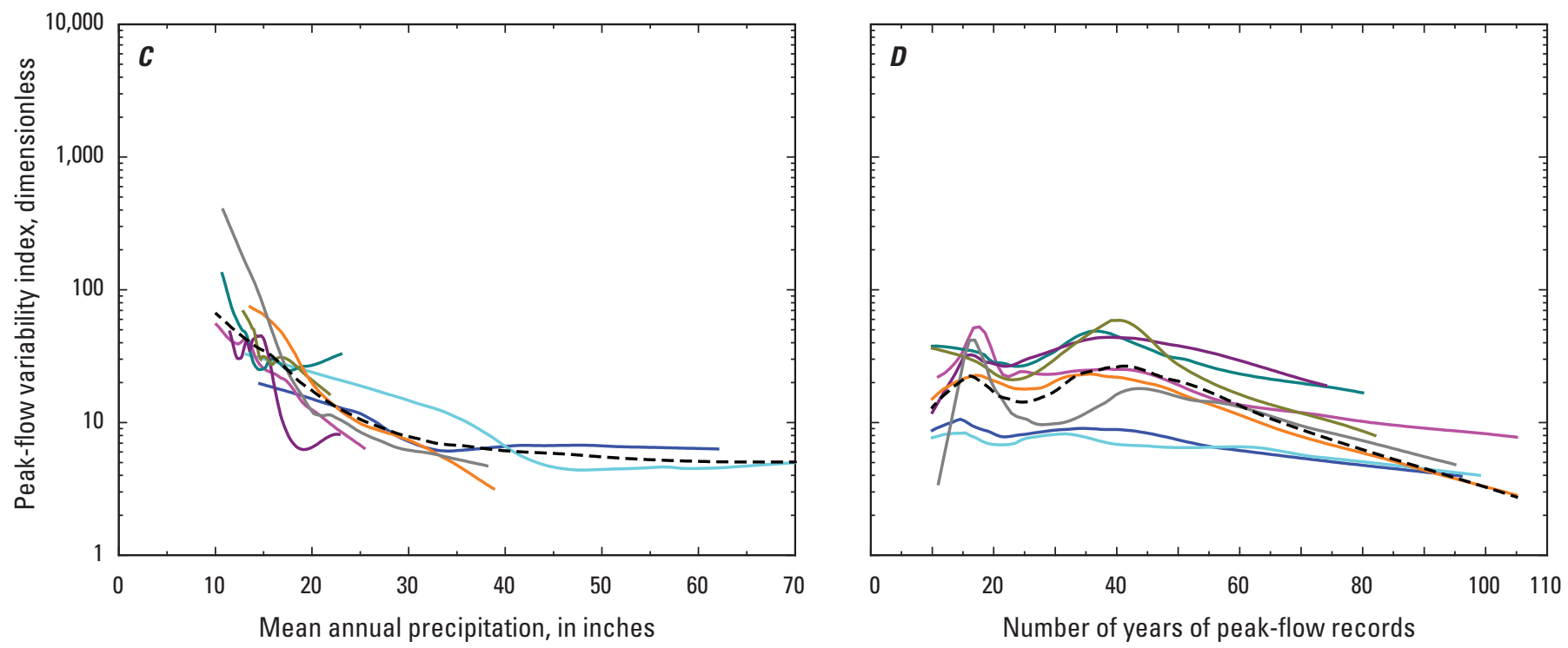

\section{EXPLANATION}

[The various lines denote locally weighted scatterplot smooths (LOWESS; Cleveland, 1985) fitted through the datasets described below]
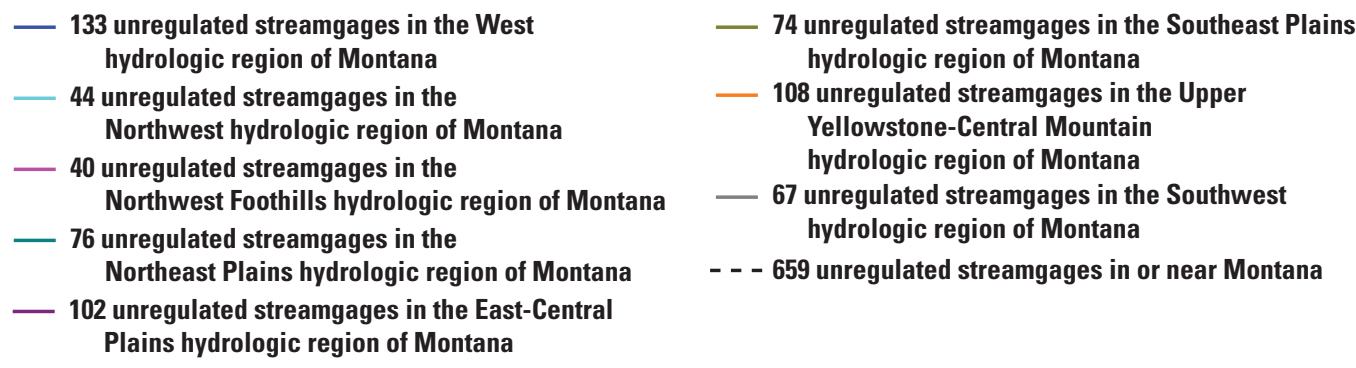

Figure 4. Locally weighted scatterplot smooths (LOWESS; Cleveland, 1985) fitted through relations between peak-flow variability index and contributing drainage area, mean basin elevation, mean annual precipitation, and years of peak-flow records for each hydrologic regions in Montana. $A$, Peak-flow variability and contributing drainage area relations. $B$, Peak-flow variability and mean basin elevation relations. $C$, Peak-flow variability and mean annual precipitation relations. $D$, Peak-flow variability and years of peak-flow records relations. 


\section{General Characterization of Peak-Flow Informational Needs in Montana}

A major use of peak-flow information by MDT is for design of road and highway infrastructure, including bridges, culverts, and roadside drainage ditches. As such, characterization of the drainage basins associated with the intersections of roads and streams might provide useful information for guiding optimization of the CSG network.

The most complete Montana roads dataset (Montana State Library, 2019) was geospatially analyzed in conjunction with the NHD Plus Version 2 streams dataset (Horizon Systems Corporation, 2013) to identify 12,639 intersections of roads and streams in Montana. Basin characteristics that can be computed by the Montana StreamStats application (McCarthy and others, 2016) were determined for each road and stream intersection. The basin characteristics determined for each road and stream intersection represent the entire drainage basin upstream from the road and stream intersection rather than just the intervening area between nested road and stream intersections on the same stream channel. The data for the road and stream intersections were generated during this study and are available as a USGS data release (Dutton and others, 2021).

Statistical summaries of selected drainage-basin characteristics of the 12,639 road and stream intersections in Montana are presented in tables 4 and 5. Statistical summaries of selected drainage-basin characteristics of 735 streamgages that currently (2020) have 10 or more years of peak-flow records and include regulated and unregulated streamgages are also shown in tables 4 and 5. Regulated and unregulated streamgages are included because the road and stream intersections are on regulated and unregulated streams. The minimum drainage area for the road and stream intersections was $0.31 \mathrm{mi}^{2}$ and was a function of the spatial resolution of NHD Plus Version 2 streams dataset (Horizon Systems Corporation, 2013) that serves as the source of most basic data supporting the Montana StreamStats application (McCarthy and others, 2016). Intuitively, there are numerous road and stream intersections in Montana that have drainage areas less than $0.31 \mathrm{mi}^{2}$, but the $0.31-\mathrm{mi}^{2}$ resolution threshold serves as a constraint on the characterization of the road and stream intersections. There are only 11 CSGs on streams with drainage areas less than $0.31 \mathrm{mi}^{2}$, which accounts for about 3 percent of all CSGs in Montana. Various issues related to the $0.31-\mathrm{mi}^{2}$ resolution threshold are not considered to have a substantial effect on the investigation of peak-flow informational needs in Montana.

Of the 735 regulated and unregulated streamgages in or near Montana, 20 of the streamgages are in Canada or Yellowstone National Park on streams that flow into Montana; those streamgages are considered to be representative of hydroclimatic characteristics of streams in Montana, but they are located outside of the Montana border and are not within the boundaries of the eight hydrologic regions. Thus,
715 regulated and unregulated streamgages are used in various analyses in this report that apply to regulated and unregulated streamgages within the eight hydrologic regions.

Cumulative distribution functions (CDFs) of selected basin characteristics (drainage area, mean basin elevation, and mean annual precipitation) for the road and stream intersections and for the streamgages are shown in figure 5 . The basin characteristics were selected for presentation because they are important factors affecting the large variability in streamflow characteristics across Montana.

For a hypothetical ideal streamgaging network, it might be desirable that the pattern of the streamgage CDFs in figure 5 would closely resemble the pattern of the road and stream intersection CDFs, but such a hypothetical ideal streamgaging network is not realistic for several reasons. For example, continuous streamgages, which comprise about 56 percent of the 735 streamgages represented in figure 5 , generally are established based on specific needs for streamflow information to address various water-management issues and generally are not intended to provide reasonable representation of hydroclimatic settings across Montana. Also, although CSGs have been established with the intention of providing reasonable representation of hydroclimatic settings across Montana, the decisions concerning establishment and discontinuation of CSGs often are based on subjective professional judgement and (or) operational considerations unrelated to informational value in representation of hydroclimatic settings. Further, some basic statistical characteristics of the road and stream intersections dataset could make it an unrealistic model for managing the streamgaging network. For example, the median contributing drainage of the 12,639 road and stream intersections is $3.85 \mathrm{mi}^{2}$ (tables 4 and 5). Clearly, practical considerations would negate developing a streamgaging network with a median contributing drainage area less than $5 \mathrm{mi}^{2}$. But, evaluating the streamgaging network in relation to the road and stream intersections dataset still might have utility if it is recognized that the pattern of the streamgage CDFs (fig. 5) ideally would have general characteristics that reasonably represent the road and stream intersections general characteristics. For example, it might be desirable that the CDFs of the streamgaging network generally consistently vary across the range of the CDFs of the road and stream intersections dataset.

Brief guidance in interpreting the road and stream intersections and streamgage CDF relations in figure 5 might be useful. Where streamgage CDFs plot above the road and stream intersection CDFs, the basin characteristic values are overrepresented in the streamgage network; this pattern is rare. For example, in figure $5 \mathrm{~A}$, streamgage CDFs plot above the road and stream intersection CDFs in the range of contributing drainage area of $0.08-0.31 \mathrm{mi}^{2}$, primarily because of the resolution threshold of the road and stream intersections dataset. Where the streamgage CDFs plot below the road and stream intersection CDFs, the basin characteristic values are underrepresented in the streamgage network; this pattern is predominant. The streamgage CDFs plot below the road and stream 
Table 4. Statistical summaries of contributing drainage area and elevation-related and slope-related drainage-basin characteristics associated with road and stream intersections, and streamgages (regulated and unregulated) in or near Montana.

[CONTDA, contributing drainage area, in square miles; ELEV, mean basin elevation, in feet; ELEVMAX, maximum basin elevation, in feet; MINBELEV, minimum basin elevation, in feet; RELIEF, maximum minus minimum elevation, in feet; $E L_{5000}$, percentage of basin above 5,000 feet elevation; $E L_{6000}$, percentage of basin above 6,000 feet elevation; BSLDEM30, mean basin slope; $S L O P 30 \_30 M$, percentage of basin with slopes greater than or equal to 30 percent; NFSL30_30M, percentage of basin with north-facing slopes greater than or equal to 30 percent; SLOP50_30M, percentage of basin with slopes greater than or equal to 50 percent; --, no data]

\begin{tabular}{|c|c|c|c|c|c|c|c|c|c|c|c|}
\hline \multirow{3}{*}{$\begin{array}{l}\text { Summary } \\
\text { statistic }\end{array}$} & \multicolumn{11}{|c|}{ Basin characteristics computed by the Montana StreamStats application (McCarthy and others, 2016) as indicated by the StreamStats abbreviations } \\
\hline & \multirow[b]{2}{*}{ CONTDA } & \multicolumn{6}{|c|}{ Elevation-related basin characteristics } & \multicolumn{4}{|c|}{ Slope-related basin characteristics } \\
\hline & & ELEV & ELEVMAX & MINBELEV & RELIEF & $E L_{5000}$ & $E L_{6000}$ & BSLDEM30 & SLOP30_30M & NFSL30_30M & SLOP50_30M \\
\hline \multicolumn{12}{|c|}{ Summary statistics for 12,639 road and stream intersections in Montana } \\
\hline 10th percentile ${ }^{1}$ & 0.44 & 2,689 & 2,863 & 2,458 & 162 & 0.00 & 0.00 & 2.3 & 0.00 & 0.00 & 0.00 \\
\hline Median & 3.85 & 4,173 & 4,920 & 3,561 & 845 & 0.00 & 0.00 & 11.5 & 3.63 & 0.70 & 0.03 \\
\hline 90th percentile ${ }^{1}$ & 125.92 & 6,735 & 9,140 & 5,639 & 4,565 & 100.00 & 89.79 & 33.8 & 54.91 & 17.74 & 19.94 \\
\hline \multicolumn{12}{|c|}{ Summary statistics for 735 streamgages (regulated and unregulated) in Montana } \\
\hline 10th percentile ${ }^{1}$ & 1.60 & 2,693 & -- & -- & 320 & 0.00 & 0.00 & 4.3 & 0.00 & -- & -- \\
\hline Median & 59.30 & 4,641 & -- & -- & 3,090 & 27.27 & 3.99 & 16.0 & 13.02 & -- & -- \\
\hline 90th percentile ${ }^{1}$ & $2,626.20$ & 7,059 & -- & -- & 6,779 & 100.00 & 86.24 & 39.8 & 63.55 & -- & -- \\
\hline \multicolumn{12}{|c|}{ Summary statistics for 2,380 road and stream intersections in the West hydrologic region (hydrologic region 1, fig. 1) } \\
\hline 10th percentile ${ }^{1}$ & 0.50 & 3,400 & 4,142 & 2,630 & 606 & 0.00 & 0.00 & 8.6 & 1.08 & 0.00 & 0.00 \\
\hline Median & 8.46 & 4,741 & 6,565 & 3,415 & 2,817 & 35.00 & 4.00 & 26.8 & 38.85 & 9.76 & 7.57 \\
\hline 90th percentile ${ }^{1}$ & 254.98 & 6,239 & 9,056 & 4,965 & 5,360 & 100.00 & 60.67 & 44.9 & 79.67 & 27.62 & 40.43 \\
\hline \multicolumn{12}{|c|}{ Summary statistics for 141 streamgages (regulated and unregulated) in the West hydrologic region (hydrologic region 1, fig. 1) } \\
\hline 10th percentile ${ }^{1}$ & 4.71 & 4,412 & -- & -- & 2,801 & 22.41 & 0.79 & 20.8 & 25.30 & -- & -- \\
\hline Median & 65.90 & 5,390 & -- & -- & 4,502 & 60.14 & 32.12 & 32.9 & 52.58 & -- & -- \\
\hline 90th percentile ${ }^{1}$ & $2,824.00$ & 6,568 & -- & -- & 7,039 & 98.06 & 70.55 & 46.9 & 78.79 & -- & -- \\
\hline \multicolumn{12}{|c|}{ Summary statistics for 356 road and stream intersections in Northwest hydrologic region (hydrologic region 2, fig. 1) } \\
\hline 10th percentile ${ }^{1}$ & 0.46 & 4,316 & 4,727 & 3,369 & 373 & 0.00 & 0.00 & 5.7 & 0.00 & 0.00 & 0.00 \\
\hline Median & 4.19 & 5,493 & 7,377 & 4,400 & 2,788 & 72.00 & 21.23 & 28.5 & 41.24 & 11.60 & 12.06 \\
\hline 90th percentile ${ }^{1}$ & 103.51 & 6,246 & 9,383 & 5,173 & 5,071 & 100.00 & 61.92 & 49.2 & 75.44 & 25.19 & 45.38 \\
\hline \multicolumn{12}{|c|}{ Summary statistics for 49 streamgages (regulated and unregulated) in the Northwest hydrologic region (hydrologic region 2, fig. 1) } \\
\hline 10th percentile ${ }^{1}$ & 8.21 & 5,060 & -- & -- & 2,587 & 35.33 & 0.95 & 10.3 & 3.94 & -- & -- \\
\hline Median & 115.00 & 5,916 & -- & -- & 4,885 & 78.12 & 44.81 & 41.2 & 57.63 & -- & -- \\
\hline 90th percentile ${ }^{1}$ & 945.80 & 6,479 & -- & -- & 6,218 & 97.49 & 68.65 & 52.8 & 73.02 & -- & -- \\
\hline \multicolumn{12}{|c|}{ Summary statistics for 1,043 road and stream intersections in the Northwest Foothills hydrologic region (hydrologic region 3, fig. 1 ) } \\
\hline 10th percentile ${ }^{1}$ & 0.42 & 3,225 & 3,315 & 3,034 & 78 & 0.00 & 0.00 & 1.2 & 0.00 & 0.00 & 10th percentile ${ }^{1}$ \\
\hline Median & 2.25 & 3,735 & 3,931 & 3,484 & 276 & 0.00 & 0.00 & 3.5 & 0.00 & 0.00 & Median \\
\hline 90th percentile ${ }^{1}$ & 75.15 & 4,414 & 6,122 & 4,029 & 2,549 & 4.00 & 0.00 & 11.6 & 7.02 & 2.73 & 90th percentile ${ }^{1}$ \\
\hline
\end{tabular}


Table 4. Statistical summaries of contributing drainage area and elevation-related and slope-related drainage-basin characteristics associated with road and stream intersections, and streamgages (regulated and unregulated) in or near Montana._Continued

[CONTDA, contributing drainage area, in square miles; $E L E V$, mean basin elevation, in feet; ELEVMAX, maximum basin elevation, in feet; MINBELEV, minimum basin elevation, in feet; RELIEF, maximum minus minimum elevation, in feet; $E L_{5000}$, percentage of basin above 5,000 feet elevation; $E L_{6000}$, percentage of basin above 6,000 feet elevation; $B S L D E M 30$, mean basin slope; $S L O P 30$ 30M, percentage of basin with slopes greater than or equal to 30 percent; NFSL30_30M, percentage of basin with north-facing slopes greater than or equal to 30 percent; SLOP50_30M, percentage of basin with slopes greater than or equal to 50 percent; --, no data]

\begin{tabular}{|c|c|c|c|c|c|c|c|c|c|c|c|}
\hline \multirow{3}{*}{$\begin{array}{l}\text { Summary } \\
\text { statistic }\end{array}$} & \multicolumn{11}{|c|}{ Basin characteristics computed by the Montana StreamStats application (McCarthy and others, 2016) as indicated by the StreamStats abbreviations } \\
\hline & \multirow[b]{2}{*}{ CONTDA } & \multicolumn{6}{|c|}{ Elevation-related basin characteristics } & \multicolumn{4}{|c|}{ Slope-related basin characteristics } \\
\hline & & ELEV & ELEVMAX & MINBELEV & RELIEF & $E L_{5000}$ & $E L_{6000}$ & BSLDEM30 & SLOP30_30M & NFSL30_30M & SLOP50_30M \\
\hline \multicolumn{12}{|c|}{ Summary statistics for 46 streamgages (regulated and unregulated) in the Northwest Foothills hydrologic region (hydrologic region 3, fig. 1) } \\
\hline 10th percentile ${ }^{1}$ & 0.74 & 3,145 & -- & -- & 243 & 0.00 & 0.00 & 1.8 & 0.00 & -- & -- \\
\hline Median & 60.95 & 3,938 & -- & -- & 937 & 0.00 & 0.00 & 7.3 & 1.95 & -- & -- \\
\hline 90th percentile ${ }^{1}$ & $6,227.50$ & 5,419 & -- & -- & 6,853 & 55.28 & 35.15 & 20.0 & 24.72 & -- & -- \\
\hline \multicolumn{12}{|c|}{ Summary statistics for 1,470 road and stream intersections in the Northeast Plains hydrologic region (hydrologic region 4 , fig. 1 ) } \\
\hline 10th percentile ${ }^{1}$ & 0.41 & 2,376 & 2,525 & 2,218 & 81 & 0.00 & 0.00 & 1.4 & 0.00 & 0.00 & 0.00 \\
\hline Median & 3.70 & 2,943 & 3,134 & 2,780 & 320 & 0.00 & 0.00 & 4.2 & 0.00 & 0.00 & 0.00 \\
\hline 90th percentile ${ }^{1}$ & 109.41 & 4,339 & 5,995 & 3,727 & 2,768 & 4.91 & 0.00 & 16.5 & 14.81 & 5.23 & 2.10 \\
\hline \multicolumn{12}{|c|}{ Summary statistics for 88 streamgages (regulated and unregulated) in Northeast Plains hydrologic region (hydrologic region 4, fig. 1) } \\
\hline 10th percentile ${ }^{1}$ & 1.85 & 2,461 & -- & -- & 198 & 0.00 & 0.00 & 2.0 & 0.00 & -- & -- \\
\hline Median & 86.85 & 3,035 & -- & -- & 758 & 0.00 & 0.00 & 4.9 & 0.08 & -- & -- \\
\hline 90th percentile ${ }^{1}$ & $2,540.50$ & 4,060 & -- & -- & 6,278 & 6.05 & 0.11 & 16.4 & 17.35 & -- & -- \\
\hline \multicolumn{12}{|c|}{ Summary statistics for 1,586 road and stream intersections in the East-Central Plains hydrologic region (hydrologic region 5 , fig. 1 ) } \\
\hline 10th percentile ${ }^{1}$ & 0.42 & 2,244 & 2,416 & 2,053 & 146 & 0.00 & 0.00 & 2.7 & 0.00 & 0.00 & 0.00 \\
\hline Median & 3.64 & 2,838 & 3,071 & 2,661 & 340 & 0.00 & 0.00 & 5.4 & 0.00 & 0.00 & 0.00 \\
\hline 90th percentile ${ }^{1}$ & 107.66 & 3,862 & 4,174 & 3,564 & 1,002 & 0.00 & 0.00 & 10.8 & 2.61 & 0.86 & 0.04 \\
\hline \multicolumn{12}{|c|}{ Summary statistics for 114 streamgages (regulated and unregulated) in the East-Central Plains hydrologic region (hydrologic region 5, fig. 1) } \\
\hline 10th percentile ${ }^{1}$ & 0.79 & 2,314 & -- & -- & 186 & 0.00 & 0.00 & 4.2 & 0.00 & -- & -- \\
\hline Median & 9.99 & 2,832 & -- & -- & 494 & 0.00 & 0.00 & 6.3 & 0.21 & -- & -- \\
\hline 90th percentile ${ }^{1}$ & $4,373.20$ & 4,222 & -- & -- & 6,192 & 21.40 & 9.27 & 14.0 & 9.73 & -- & -- \\
\hline \multicolumn{12}{|c|}{ Summary statistics for 1,371 road and stream intersections in the Southeast Plains hydrologic region (hydrologic region 6, fig. 1) } \\
\hline 10th percentile ${ }^{1}$ & 0.43 & 2,634 & 2,792 & 2,444 & 185 & 0.00 & 0.00 & 3.8 & 0.00 & 0.00 & 10th percentile 1 \\
\hline Median & 2.37 & 3,194 & 3,442 & 2,967 & 442 & 0.00 & 0.00 & 9.7 & 1.22 & 0.36 & Median \\
\hline 90th percentile ${ }^{1}$ & 77.05 & 3,940 & 4,352 & 3,543 & 1,089 & 0.00 & 0.00 & 17.0 & 13.28 & 4.50 & 90th percentile ${ }^{1}$ \\
\hline \multicolumn{12}{|c|}{ Summary statistics for 80 streamgages (regulated and unregulated) in the Southeast Plains hydrologic region (hydrologic region 6, fig. 1) } \\
\hline 10th percentile ${ }^{1}$ & 0.84 & 2,819 & -- & -- & 256 & 0.00 & 0.00 & 4.7 & 0.00 & -- & -- \\
\hline Median & 8.96 & 3,396 & -- & -- & 673 & 0.00 & 0.00 & 11.6 & 2.64 & -- & -- \\
\hline 90th percentile ${ }^{1}$ & $2,029.10$ & 4,629 & -- & -- & 8,413 & 20.42 & 12.58 & 17.2 & 13.74 & -- & -- \\
\hline
\end{tabular}


Table 4. Statistical summaries of contributing drainage area and elevation-related and slope-related drainage-basin characteristics associated with road and stream intersections, and streamgages (regulated and unregulated) in or near Montana.—Continued

[CONTDA, contributing drainage area, in square miles; ELEV, mean basin elevation, in feet; ELEVMAX, maximum basin elevation, in feet; MINBELEV, minimum basin elevation, in feet; RELIEF, maximum minus minimum elevation, in feet; $E L_{5000}$, percentage of basin above 5,000 feet elevation; $E L_{6000}$, percentage of basin above 6,000 feet elevation; $B S L D E M 30$, mean basin slope; $S L O P 30 \_30 M$, percentage of basin with slopes greater than or equal to 30 percent; NFSL30_30M, percentage of basin with north-facing slopes greater than or equal to 30 percent; SLOP50_30M, percentage of basin with slopes greater than or equal to 50 percent; --, no data]

\begin{tabular}{|c|c|c|c|c|c|c|c|c|c|c|c|}
\hline \multirow{3}{*}{$\begin{array}{c}\text { Summary } \\
\text { statistic }\end{array}$} & \multicolumn{11}{|c|}{ Basin characteristics computed by the Montana StreamStats application (McCarthy and others, 2016) as indicated by the StreamStats abbreviations } \\
\hline & \multirow[b]{2}{*}{ CONTDA } & \multicolumn{6}{|c|}{ Elevation-related basin characteristics } & \multicolumn{4}{|c|}{ Slope-related basin characteristics } \\
\hline & & ELEV & ELEVMAX & MINBELEV & RELIEF & $E L_{5000}$ & $E L_{6000}$ & BSLDEM30 & SLOP30_30M & NFSL30_30M & SLOP50_30M \\
\hline \multicolumn{12}{|c|}{ Summary statistics for 2,166 road and stream intersections in the Upper Yellowstone-Central Mountain hydrologic region (hydrologic region 7, fig. 1) } \\
\hline 10th percentile 1 & 0.45 & 3,634 & 3,955 & 3,300 & 259 & 0.00 & 0.00 & 3.0 & 0.00 & 0.00 & 0.00 \\
\hline Median & 3.88 & 4,889 & 5,452 & 4,342 & 1,000 & 29.54 & 0.00 & 13.2 & 6.20 & 1.51 & 0.16 \\
\hline 90th percentile 1 & 104.79 & 7,290 & 10,005 & 5,517 & 4,861 & 100.00 & 92.02 & 31.4 & 46.63 & 16.20 & 18.15 \\
\hline \multicolumn{12}{|c|}{ Summary statistics for 113 streamgages (regulated and unregulated) in the Upper Yellowstone-Central Mountain hydrologic region (hydrologic region 7, fig. 1) } \\
\hline 10th percentile 1 & 2.55 & 4,183 & -- & -- & 741 & 0.00 & 0.00 & 7.6 & 1.25 & -- & -- \\
\hline Median & 61.30 & 5,807 & -- & -- & 4,162 & 80.40 & 32.57 & 18.5 & 18.90 & -- & -- \\
\hline 90th percentile 1 & $1,143.20$ & 7,855 & -- & -- & 7,168 & 100.00 & 97.12 & 36.2 & 53.24 & -- & -- \\
\hline \multicolumn{12}{|c|}{ Summary statistics for 2,267 road and stream intersections in the Southwest hydrologic region (hydrologic region 8, fig. 1 ) } \\
\hline 10th percentile ${ }^{1}$ & 0.45 & 4,761 & 5,359 & 3,920 & 416 & 19.60 & 0.00 & 5.5 & 0.00 & 0.00 & 0.00 \\
\hline Median & 2.90 & 6,347 & 7,778 & 5,440 & 2,002 & 100.00 & 71.61 & 20.1 & 22.52 & 6.60 & 2.90 \\
\hline 90th percentile 1 & 204.86 & 7,632 & 10,212 & 6,722 & 5,027 & 100.00 & 100.00 & 32.5 & 51.58 & 18.93 & 18.88 \\
\hline \multicolumn{12}{|c|}{ Summary statistics for 84 streamgages (regulated and unregulated) in the Southwest hydrologic region (hydrologic region 8, fig. 1) } \\
\hline 10th percentile ${ }^{1}$ & 3.81 & 5,274 & -- & -- & 1,544 & 55.99 & 2.74 & 14.0 & 9.79 & -- & -- \\
\hline Median & 93.80 & 6,997 & -- & -- & 4,424 & 100.00 & 85.56 & 21.2 & 25.12 & -- & -- \\
\hline 90th percentile 1 & $2,843.40$ & 7,671 & -- & -- & 6,285 & 100.00 & 100.00 & 30.7 & 49.03 & -- & -- \\
\hline
\end{tabular}

${ }^{1}$ Nonexceedance percentile. 
Table 5. Statistical summaries of climate-related and land use and land cover related drainage-basin characteristics associated with road and stream intersections, and streamgages (regulated and unregulated) in or near Montana.

$[C O N T D A$, contributing drainage area; $P R E C I P$, mean annual precipitation, in inches; $E T 0306 M O D$, spring mean monthly evapotranspiration, in inches per month; ET0710MOD, summer mean monthly evapotranspiration, in inches per month; $A G \_O F \_D A$, percentage of basin in agricultural land; IRRIG_MT, percentage of basin under some irrigation regime; FOREST, percentage of basin in forest; LAKEAREA, percentage of basin in lakes, ponds, and reservoirs; URBAN, percentage of basin in urban; WETLAND, percentage of basin in wetlands; --, no data]

\begin{tabular}{|c|c|c|c|c|c|c|c|c|c|c|}
\hline \multirow{3}{*}{$\begin{array}{l}\text { Summary } \\
\text { Statistic }\end{array}$} & \multicolumn{10}{|c|}{ Basin characteristics computed by the Montana StreamStats application (McCarthy and others, 2016) as indicated by the StreamStats abbreviations } \\
\hline & \multirow{2}{*}{ CONTDA } & \multicolumn{3}{|c|}{ Climate-related basin characteristics } & \multicolumn{6}{|c|}{ Land use and land cover related basin characteristics } \\
\hline & & PRECIP & ET0306MOD & ETO710MOD & AG_OF_DA & IRRIGAT_MT & FOREST & LAKEAREA & URBAN & WETLAND \\
\hline \multicolumn{11}{|c|}{ Summary statistics for 12,639 road and stream intersections in Montana } \\
\hline 10th percentile ${ }^{1}$ & 0.44 & 12.4 & 1.07 & 0.59 & 0.00 & 0.00 & 0.00 & 0.00 & 0.00 & 0.00 \\
\hline Median & 3.85 & 15.7 & 1.38 & 0.99 & 2.00 & 0.00 & 4.16 & 0.00 & 1.00 & 0.00 \\
\hline 90th percentile ${ }^{1}$ & 125.92 & 29.9 & 1.75 & 1.78 & 75.00 & 5.00 & 81.47 & 0.00 & 5.00 & 2.00 \\
\hline \multicolumn{11}{|c|}{ Summary statistics for 735 streamgages (regulated and unregulated) in Montana } \\
\hline 10th percentile ${ }^{1}$ & 1.60 & 12.9 & 1.06 & 0.60 & 0.00 & -- & 0.00 & -- & 0.00 & -- \\
\hline Median & 59.30 & 18.6 & 1.44 & 1.12 & 1.53 & -- & 20.04 & -- & 0.49 & -- \\
\hline 90th percentile ${ }^{1}$ & $2,626.20$ & 39.2 & 1.78 & 1.86 & 42.34 & -- & 82.32 & -- & 3.17 & -- \\
\hline \multicolumn{11}{|c|}{ Summary statistics for 2,380 road and stream intersections in the West hydrologic region (hydrologic region 1, fig. 1) } \\
\hline 10th percentile ${ }^{1}$ & 0.50 & 15.2 & 1.54 & 1.12 & 0.00 & 0.00 & 3.49 & 0.00 & 0.00 & 0.00 \\
\hline Median & 8.46 & 23.4 & 1.71 & 1.64 & 0.00 & 0.00 & 72.61 & 0.00 & 0.00 & 0.00 \\
\hline 90th percentile ${ }^{1}$ & 254.98 & 42.2 & 1.90 & 2.31 & 18.10 & 8.00 & 91.79 & 1.00 & 7.00 & 1.00 \\
\hline \multicolumn{11}{|c|}{ Summary statistics for 141 streamgages (regulated and unregulated) in the West hydrologic region (hydrologic region 1, fig. 1) } \\
\hline 10th percentile ${ }^{1}$ & 4.71 & 20.8 & 1.60 & 1.29 & 0.00 & -- & 49.62 & -- & 0.00 & -- \\
\hline Median & 65.90 & 31.5 & 1.72 & 1.78 & 0.08 & -- & 76.38 & -- & 0.19 & -- \\
\hline 90th percentile ${ }^{1}$ & $2,824.00$ & 48.9 & 1.87 & 2.39 & 4.81 & -- & 91.95 & -- & 1.91 & -- \\
\hline \multicolumn{11}{|c|}{ Summary statistics for 356 road and stream intersections in Northwest hydrologic region (hydrologic region 2, fig. 1) } \\
\hline 10th percentile ${ }^{1}$ & 0.46 & 16.3 & 1.52 & 1.11 & 0.00 & 0.00 & 0.00 & 0.00 & 0.00 & 0.00 \\
\hline Median & 4.19 & 31.5 & 1.68 & 1.73 & 0.00 & 0.00 & 63.48 & 0.00 & 0.00 & 0.00 \\
\hline 90th percentile ${ }^{1}$ & 103.51 & 56.6 & 1.86 & 2.27 & 2.00 & 0.00 & 94.66 & 1.00 & 3.00 & 1.00 \\
\hline \multicolumn{11}{|c|}{ Summary statistics for 49 streamgages (regulated and unregulated) in the Northwest hydrologic region (hydrologic region 2, fig. 1) } \\
\hline 10th percentile ${ }^{1}$ & 8.21 & 22.8 & 1.58 & 1.35 & 0.00 & -- & 18.10 & -- & 0.00 & -- \\
\hline Median & 115.00 & 48.6 & 1.70 & 1.66 & 0.05 & -- & 55.90 & -- & 0.03 & -- \\
\hline 90th percentile ${ }^{1}$ & 945.80 & 68.6 & 1.87 & 2.08 & 2.02 & -- & 83.36 & -- & 0.78 & -- \\
\hline \multicolumn{11}{|c|}{ Summary statistics for 1,043 road and stream intersections in the Northwest Foothills hydrologic region (hydrologic region 3 , fig. 1) } \\
\hline 10th percentile ${ }^{1}$ & 0.42 & 11.3 & 1.05 & 0.61 & 1.00 & 0.00 & 0.00 & 0.00 & 0.00 & 0.00 \\
\hline Median & 2.25 & 13.0 & 1.21 & 0.77 & 66.00 & 0.00 & 0.00 & 0.00 & 2.00 & 0.00 \\
\hline 90th percentile ${ }^{1}$ & 75.15 & 17.0 & 1.50 & 1.26 & 96.00 & 23.80 & 3.38 & 1.00 & 7.00 & 1.00 \\
\hline
\end{tabular}


Table 5. Statistical summaries of climate-related and land use and land cover related drainage-basin characteristics associated with road and stream intersections, and streamgages (regulated and unregulated) in or near Montana.-Continued

[CONTDA, contributing drainage area; $P R E C I P$, mean annual precipitation, in inches; ET0306MOD, spring mean monthly evapotranspiration, in inches per month; ET0710MOD, summer mean monthly evapotranspiration, in inches per month; $A G_{-} O F_{-} D A$, percentage of basin in agricultural land; IRRIG_MT, percentage of basin under some irrigation regime; FOREST, percentage of basin in forest; $L A K E A R E A$, percentage of basin in lakes, ponds, and reservoirs; URBAN, percentage of basin in urban; WETLAND, percentage of basin in wetlands; --, no data]

\begin{tabular}{|c|c|c|c|c|c|c|c|c|c|c|}
\hline \multirow{3}{*}{$\begin{array}{l}\text { Summary } \\
\text { Statistic }\end{array}$} & \multicolumn{10}{|c|}{ Basin characteristics computed by the Montana StreamStats application (McCarthy and others, 2016) as indicated by the StreamStats abbreviations } \\
\hline & \multirow{2}{*}{ CONTDA } & \multicolumn{3}{|c|}{ Climate-related basin characteristics } & \multicolumn{6}{|c|}{ Land use and land cover related basin characteristics } \\
\hline & & PRECIP & ET0306MOD & ET0710MOD & AG_OF_DA & IRRIGAT_MT & FOREST & LAKEAREA & URBAN & WETLAND \\
\hline \multicolumn{11}{|c|}{ Summary statistics for 46 streamgages (regulated and unregulated) in the Northwest Foothills hydrologic region (hydrologic region 3, fig. 1) } \\
\hline 10 th percentile $^{1}$ & 0.74 & 12.3 & 1.11 & 0.61 & 5.78 & -- & 0.00 & -- & 0.33 & -- \\
\hline Median & 60.95 & 14.8 & 1.31 & 0.95 & 42.61 & -- & 0.01 & -- & 1.78 & -- \\
\hline 90th percentile ${ }^{1}$ & $6,227.50$ & 21.9 & 1.52 & 1.24 & 85.70 & -- & 34.87 & -- & 3.97 & -- \\
\hline \multicolumn{11}{|c|}{ Summary statistics for 1,470 road and stream intersections in the Northeast Plains hydrologic region (hydrologic region 4 , fig. 1) } \\
\hline 10th percentile ${ }^{1}$ & 0.41 & 11.3 & 1.05 & 0.61 & 0.00 & 0.00 & 0.00 & 0.00 & 0.00 & 0.00 \\
\hline Median & 3.70 & 13.4 & 1.17 & 0.88 & 42.00 & 0.00 & 0.00 & 0.00 & 2.00 & 0.00 \\
\hline 90th percentile ${ }^{1}$ & 109.41 & 18.4 & 1.57 & 1.39 & 95.00 & 0.00 & 12.02 & 1.00 & 5.00 & 3.00 \\
\hline \multicolumn{11}{|c|}{ Summary statistics for 88 streamgages (regulated and unregulated) in Northeast Plains hydrologic region (hydrologic region 4, fig. 1) } \\
\hline 10th percentile ${ }^{1}$ & 1.85 & 12.3 & 1.05 & 0.63 & 0.39 & -- & 0.00 & -- & 0.00 & -- \\
\hline Median & 86.85 & 13.9 & 1.19 & 0.91 & 25.31 & -- & 0.10 & -- & 0.50 & -- \\
\hline 90th percentile ${ }^{1}$ & $2,540.50$ & 18.8 & 1.42 & 1.30 & 69.45 & -- & 10.94 & -- & 3.47 & -- \\
\hline \multicolumn{11}{|c|}{ Summary statistics for 1,586 road and stream intersections in the East-Central Plains hydrologic region (hydrologic region 5, fig. 1 ) } \\
\hline 10th percentile ${ }^{1}$ & 0.42 & 12.5 & 0.98 & 0.49 & 0.00 & 0.00 & 0.00 & 0.00 & 0.00 & 0.00 \\
\hline Median & 3.64 & 13.4 & 1.11 & 0.70 & 16.00 & 0.00 & 0.02 & 0.00 & 1.00 & 0.98 \\
\hline 90th percentile ${ }^{1}$ & 107.66 & 14.7 & 1.24 & 0.99 & 74.50 & 1.00 & 13.85 & 0.00 & 4.00 & 2.00 \\
\hline \multicolumn{11}{|c|}{ Summary statistics for 114 streamgages (regulated and unregulated) in the East-Central Plains hydrologic region (hydrologic region 5, fig. 1) } \\
\hline 10th percentile ${ }^{1}$ & 0.79 & 12.4 & 0.95 & 0.48 & 0.00 & -- & 0.00 & -- & 0.00 & -- \\
\hline Median & 9.99 & 13.4 & 1.10 & 0.70 & 12.62 & -- & 0.12 & -- & 0.95 & -- \\
\hline 90th percentile ${ }^{1}$ & $4,373.20$ & 16.7 & 1.27 & 0.98 & 54.02 & -- & 16.37 & -- & 5.53 & -- \\
\hline \multicolumn{11}{|c|}{ Summary statistics for 1,371 road and stream intersections in the Southeast Plains hydrologic region (hydrologic region 6, fig. 1) } \\
\hline 10th percentile ${ }^{1}$ & 0.43 & 13.5 & 1.04 & 0.53 & 0.00 & 0.00 & 0.00 & 0.00 & 0.00 & 0.00 \\
\hline Median & 2.37 & 14.5 & 1.17 & 0.67 & 0.00 & 0.00 & 3.41 & 0.00 & 0.60 & 1.07 \\
\hline 90th percentile ${ }^{1}$ & 77.05 & 16.1 & 1.38 & 0.99 & 24.00 & 0.00 & 36.50 & 0.00 & 1.18 & 2.00 \\
\hline \multicolumn{11}{|c|}{ Summary statistics for 80 streamgages (regulated and unregulated) in the Southeast Plains hydrologic region (hydrologic region 6, fig. 1) } \\
\hline 10th percentile ${ }^{1}$ & 0.84 & 13.9 & 1.04 & 0.54 & 0.00 & -- & 0.00 & -- & 0.00 & -- \\
\hline Median & 8.96 & 14.9 & 1.22 & 0.70 & 0.64 & -- & 7.92 & -- & 0.39 & -- \\
\hline 90th percentile ${ }^{1}$ & $2,029.10$ & 18.2 & 1.43 & 1.00 & 4.91 & -- & 26.43 & -- & 1.99 & -- \\
\hline
\end{tabular}


Table 5. Statistical summaries of climate-related and land use and land cover related drainage-basin characteristics associated with road and stream intersections, and streamgages (regulated and unregulated) in or near Montana.-Continued

$[C O N T D A$, contributing drainage area; $P R E C I P$, mean annual precipitation, in inches; $E T 0306 M O D$, spring mean monthly evapotranspiration, in inches per month; ET0710MOD, summer mean monthly evapotranspiration, in inches per month; $A G$ OF DA, percentage of basin in agricultural land; IRRIG MT, percentage of basin under some irrigation regime; FOREST, percentage of basin in forest; $L A K E A R E A$, percentage of basin in lakes, ponds, and reservoirs; URBAN, percentage of basin in urban; WETLAND, percentage of basin in wetlands; --, no data]

\begin{tabular}{|c|c|c|c|c|c|c|c|c|c|c|}
\hline \multirow{3}{*}{$\begin{array}{l}\text { Summary } \\
\text { Statistic }\end{array}$} & \multicolumn{10}{|c|}{ Basin characteristics computed by the Montana StreamStats application (McCarthy and others, 2016) as indicated by the StreamStats abbreviations } \\
\hline & \multirow{2}{*}{ CONTDA } & \multicolumn{3}{|c|}{ Climate-related basin characteristics } & \multicolumn{6}{|c|}{ Land use and land cover related basin characteristics } \\
\hline & & PRECIP & ET0306MOD & ET0710MOD & AG_OF_DA & IRRIGAT_MT & FOREST & LAKEAREA & URBAN & WETLAND \\
\hline \multicolumn{11}{|c|}{ Summary statistics for 2,166 road and stream intersections in the Upper Yellowstone-Central Mountain hydrologic region (hydrologic region 7, fig. 1) } \\
\hline 10 th percentile ${ }^{1}$ & 0.45 & 14.7 & 1.18 & 0.61 & 0.00 & 0.00 & 0.00 & 0.00 & 0.00 & 0.00 \\
\hline Median & 3.88 & 17.7 & 1.55 & 1.09 & 4.00 & 0.00 & 5.62 & 0.00 & 0.92 & 1.04 \\
\hline 90th percentile 1 & 104.79 & 29.8 & 1.77 & 1.59 & 60.00 & 16.00 & 63.41 & 0.00 & 3.00 & 3.00 \\
\hline \multicolumn{11}{|c|}{ Summary statistics for 113 streamgages (regulated and unregulated) in the Upper Yellowstone-Central Mountain hydrologic region (hydrologic region 7, fig. 1) } \\
\hline 10th percentile ${ }^{1}$ & 2.55 & 16.2 & 1.30 & 0.67 & 0.00 & -- & 0.15 & -- & 0.00 & -- \\
\hline Median & 61.30 & 21.4 & 1.63 & 1.19 & 2.77 & -- & 27.95 & -- & 0.50 & -- \\
\hline 90th percentile 1 & $1,143.20$ & 32.2 & 1.78 & 1.64 & 17.76 & -- & 75.28 & -- & 2.34 & -- \\
\hline \multicolumn{11}{|c|}{ Summary statistics for 2,267 road and stream intersections in the Southwest hydrologic region (hydrologic region 8 , fig. 1) } \\
\hline 10th percentile ${ }^{1}$ & 0.45 & 11.8 & 1.25 & 0.70 & 0.00 & 0.00 & 0.00 & 0.00 & 0.00 & 0.00 \\
\hline Median & 2.90 & 18.4 & 1.41 & 1.08 & 0.00 & 0.00 & 24.75 & 0.00 & 1.00 & 0.00 \\
\hline 90th percentile 1 & 204.86 & 27.1 & 1.59 & 1.43 & 9.00 & 5.00 & 80.74 & 0.00 & 6.00 & 1.00 \\
\hline \multicolumn{11}{|c|}{ Summary statistics for 84 streamgages (regulated and unregulated) in the Southwest hydrologic region (hydrologic region 8 , fig. 1) } \\
\hline 10th percentile ${ }^{1}$ & 3.81 & 14.4 & 1.27 & 0.76 & 0.00 & -- & 3.32 & -- & 0.00 & -- \\
\hline Median & 93.80 & 21.2 & 1.46 & 1.16 & 0.49 & -- & 36.36 & -- & 0.62 & -- \\
\hline 90th percentile ${ }^{1}$ & $2,843.40$ & 30.5 & 1.62 & 1.46 & 5.76 & -- & 83.60 & -- & 2.00 & -- \\
\hline
\end{tabular}

${ }^{1}$ Nonexceedance percentile. 


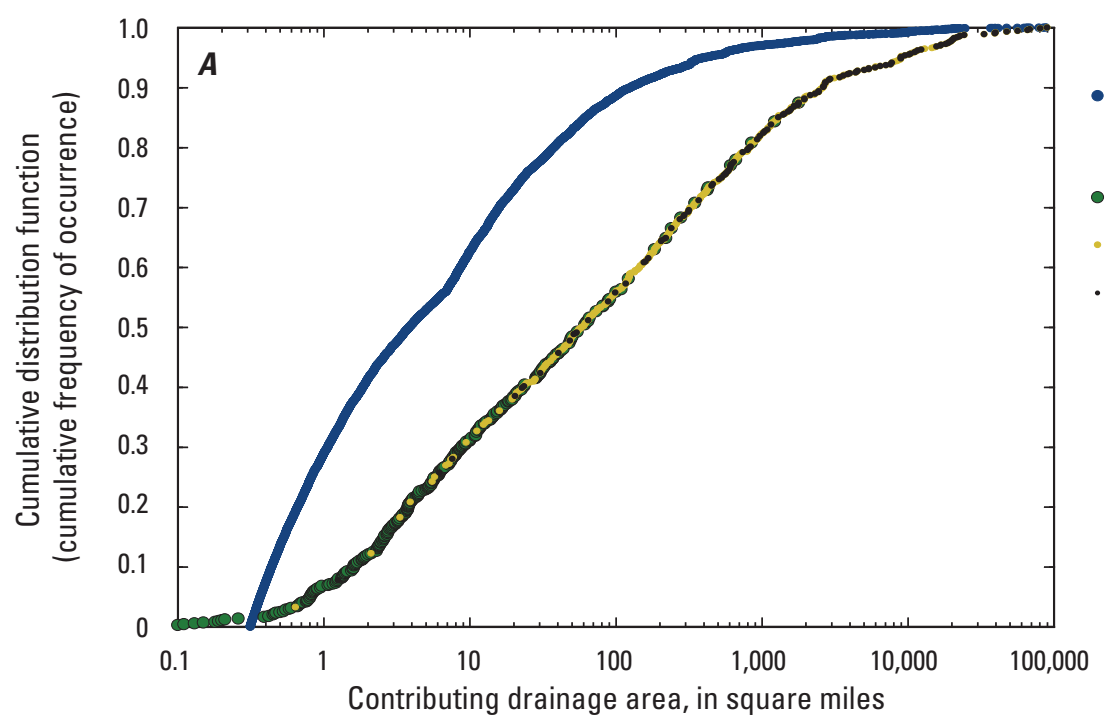

EXPLANATION

- Road and stream intersection Streamgages

- Crest-stage streamgage

- Unregulated continuous streamgage

- Regulated continuous streamgage

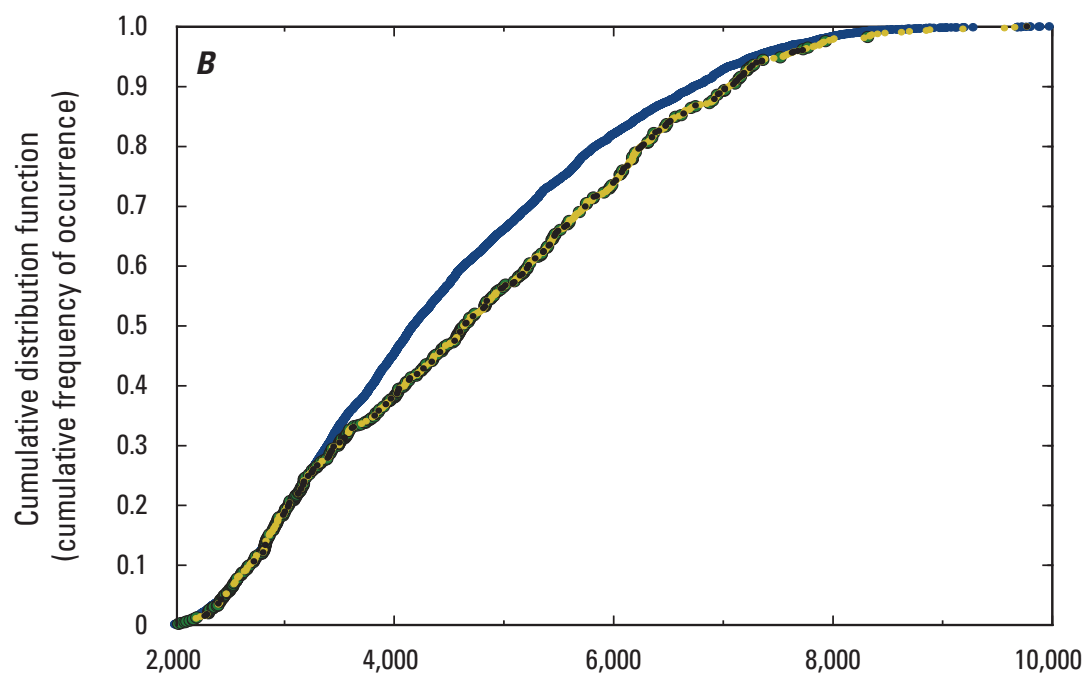

Mean basin elevation, in feet above the North American Vertical Datum of 1988

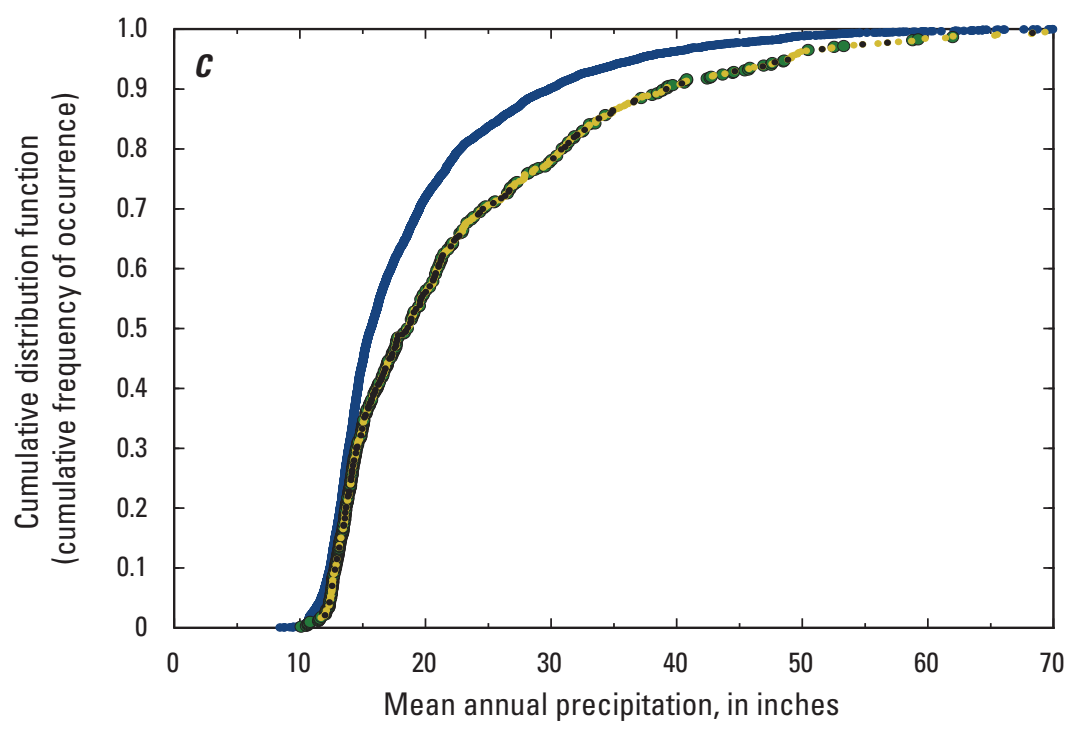

Figure 5. Cumulative distribution functions of selected drainage-basin characteristics for 12,639 road and stream intersections and for 735 streamgages (regulated and unregulated) in or near Montana. $A$, Contributing drainage area relations. $B$, Mean basin elevation relations. $C$, Mean annual precipitation relations. 
intersection CDFs from 0.32 to about $88,000 \mathrm{mi}^{2}$. In the range from 0.32 to about $3 \mathrm{mi}^{2}$, the deviation of the streamgage CDFs from the road and stream intersection CDFs strongly increases, denoting strong underrepresentation. From about 3 to about $100 \mathrm{mi}^{2}$, the deviation of the streamgage CDFs from the road and stream intersection CDFs moderately increases but is considered to generally provide reasonable representation. From about 100 to about $88,000 \mathrm{mi}^{2}$, the deviation of the streamgage CDFs from the road and stream intersection CDFs moderately decreases and is considered to provide better representation than for contributing drainage areas less than 100 $\mathrm{mi}^{2}$. The general interpretation described for road and stream intersections and streamgage $\mathrm{CDF}$ relations with respect to contributing drainage area (fig. $5 \mathrm{~A}$ ) also can be applied to relations with respect to mean basin elevation (fig. $5 B$ ) and mean annual precipitation (fig. 5C).

The road and stream intersection and streamgage CDF relations shown in figure 5 are based on statewide datasets with no distinction between hydrologic regions. Exploratory analyses indicated that the CDF relations are substantially different among the hydrologic regions and determined the need to consider each hydrologic region independently when evaluating the CDF relations. As such, the CDF relations are addressed for each hydrologic region in the section "Description of Peak-Flow Variability and PeakFlow Informational Needs, and Consideration of Regional Regression Analyses by Hydrologic Region.”

\section{Consideration of Regional Regression Analyses in Managing the Crest-Stage Gage Network}

An important objective of the CSG network is to provide data for developing RREs for estimating frequencies at ungaged sites in Montana. In providing regional information, the CSG network is vital to collecting peak-flow data on small drainage basins that typically are not addressed by continuous streamflow operations. As such, consideration of regional regression analyses is important in investigating and managing the CSG network.

Selected information concerning RREs for Montana (Sando, R., and others, 2018) is presented in table 6. The mean standard error of prediction (SEP) is an important metric for confidence in RRE results and varies substantially among the hydrologic regions. For example, the 1-percent annual exceedance probability (AEP) RRE for the West hydrologic region has an SEP of 56.0 percent, which is somewhat less than the area-weighted mean SEP for all hydrologic regions in Montana (63.3 percent) (table 6). In contrast, the 1-percent AEP RRE for the East-Central Plains hydrologic region has an SEP of 73.5 percent, which is somewhat higher than the statewide mean.

Diagnostic statistics, including leverage and influence, from regional regression analyses also might be important in evaluating the peak-flow informational value of individual streamgages. Information on streamgages with significant leverage and influence statistics from regional regression

Table 6. Selected information concerning regional regression equations for Montana (Sando, R., and others, 2018).

$\left[n\right.$, number of streamgages in regression analysis; $S E P$, mean standard error of prediction; $Q_{A E P}$, peak-flow magnitude, in cubic feet per second, for annual exceedance probability (AEP), in percent (where AEP equals 10, 4, or 1 percent); CONTDA, contributing drainage area, in square miles; PRECIP, mean annual precipitation, in inches; FOREST, percentage of basin that is forest; $E L_{5000}$, percentage of basin above 5,000 feet elevation; SLOP30_30M, percentage of basin with slope greater than 30 percent; $E T 0306 M O D$, mean spring (March-June) evapotranspiration, in inches per month; $E L_{6000}$, percentage of basin above 6,000 feet elevation; --, not applicable]

\begin{tabular}{|c|c|c|c|c|c|c|}
\hline \multirow{2}{*}{$\begin{array}{l}\text { Hydrologic region (ordered clockwise } \\
\text { from northwestern Montana) }\end{array}$} & \multirow{2}{*}{$\begin{array}{l}\text { Hydrologic region } \\
\text { number (fig. 1) }\end{array}$} & \multirow{2}{*}{$n$} & \multirow{2}{*}{$\begin{array}{l}\text { Explanatory variables in } \\
\text { regression analysis }\end{array}$} & \multicolumn{3}{|c|}{$S E P$, in percent } \\
\hline & & & & $Q_{10}$ & $\boldsymbol{Q}_{4}$ & $\mathbf{Q}_{1}$ \\
\hline West $^{1}$ & 1 & 113 & CONTDA, PRECIP, FOREST & 52.8 & 53.2 & 56.0 \\
\hline Northwest Foothills ${ }^{1}$ & 3 & 31 & CONTDA, PRECIP & 56.4 & 55.2 & 65.8 \\
\hline Northeast Plains ${ }^{1}$ & 4 & 64 & CONTDA, $E L_{5000}$ & 53.1 & 49.2 & 54.5 \\
\hline Southeast Plains ${ }^{1}$ & 6 & 68 & $\begin{array}{l}\text { CONTDA, FOREST, ET- } \\
\text { 0306MOD }\end{array}$ & 83.4 & 72.1 & 71.1 \\
\hline Upper Yellowstone-Central Mountain ${ }^{1}$ & 7 & 91 & CONTDA, $E L_{6000}$ & 73.0 & 68.4 & 69.0 \\
\hline Southwest ${ }^{1}$ & 8 & 48 & $C O N T D A, E L_{6000}$ & 72.1 & 71.3 & 73.8 \\
\hline
\end{tabular}

${ }^{1}$ Regression equations were developed using generalized least squares regression analyses.

${ }^{2}$ Regression equations were developed using weighted least squares regression analyses. 
analyses (Sando, R., and others, 2018) is presented in table 7. A leverage statistic expresses the distance of the basin characteristics of an individual streamgage from the center of the basin characteristics of all streamgages in the regression analysis. A significant leverage value indicates that a streamgage is unusual in the regression analysis and has basin characteristics that are not well represented. An influence statistic expresses how much the inclusion of an individual streamgage affects the regression predictions. A significant influence value indicates that a streamgage has greater than typical effect on the regression predictions. The leverage and influence statistics vary among the hydrologic regions. For example, for the 1-percent AEP regression for the West hydrologic region, 8.0 percent of the streamgages have significant leverage and 10.6 percent of the streamgages have significant influence; these percentages are similar to significant leverage and influence percentages (8.2 and 10.4 percent, respectively) for all of the streamgages in Montana included in the regional regression analyses (table 7). In contrast, for the 1-percent AEP regression for the Upper Yellowstone-Central Mountain hydrologic region, 11.0 percent of the streamgages have significant leverage and 14.3 percent of the streamgages have significant influence; these percentages are somewhat higher than significant leverage and influence percentages (8.2 and 10.4 percent, respectively) for all of the streamgages in Montana included in the regional regression analyses.

The SEPs of the RREs and the leverage and influence statistics vary considerably among the hydrologic regions, which further supports a need to consider each hydrologic region independently when evaluating the Montana streamgage network. As such, consideration of regional regression analyses for each hydrologic region is included in the section "Description of Peak-Flow Variability and PeakFlow Informational Needs, and Consideration of Regional Regression Analyses by Hydrologic Region."

Consideration of regional regression analyses in managing the CSG network is complex and might involve various approaches or a combination of approaches. Various information from the regional regression analyses might assist in identifying needed additional peak-flow information from under-represented hydroclimatic settings that might improve the coverage and accuracy of the RREs. However, additional streamgaging generally would require additional funding and substantial time before adequate data are collected to provide frequency estimates. Establishing new CSGs in targeted hydroclimatic settings would require at least a decade of data collection. In some cases, useful data might be obtained by reactivating discontinued streamgages in targeted hydroclimatic settings, especially for discontinued streamgages with less than 10 years of record that currently are not analyzed for frequencies. The approach of managing the CSG network in relation to regional regression analyses by collecting additional information would attempt to improve the RREs by reducing sampling error. Another approach of managing the CSG network in relation to regional regression analyses might involve attempting to improve the RREs by reducing the model error. Such an approach might involve investigating the streamgages with significant leverage and influence and considering whether to exclude those streamgages from the regional regression analyses. Excluding significant leverage and influence streamgages might reduce the model error but might also reduce the coverage of some hydroclimatic settings. Reducing the coverage of some hydroclimatic settings might result in users of the RREs needing to consider other methods (for example, rainfall and runoff modeling) for estimating frequencies at ungaged sites. Managing the CSG network in relation to regional regression analyses might best be accomplished by a combination of the approaches that attempt to reduce sampling error or model error. 
Table 7. Information on streamgages with significant leverage and influence statistics from regional regression analyses (Sando, R., and others, 2018).

[AEP, annual exceedance probability; \%, percent; NA, not applicable]

\begin{tabular}{|c|c|c|c|c|c|c|c|c|c|c|c|c|}
\hline \multirow{3}{*}{ Summary statistic } & \multicolumn{4}{|c|}{$\begin{array}{l}\text { Information for all streamgages (both continuous } \\
\text { streamgages and crest-stage gages) }\end{array}$} & \multicolumn{4}{|c|}{ Information for continuous streamgages } & \multicolumn{4}{|c|}{ Information for crest-stage gages } \\
\hline & \multirow{2}{*}{$\begin{array}{c}\text { Information on } \\
\text { streamgages } \\
\text { with } \\
\text { significant } \\
\text { leverage }\end{array}$} & \multicolumn{3}{|c|}{$\begin{array}{l}\text { Information on streamgages } \\
\text { with significant influence for } \\
\text { the percentage AEP } \\
\text { regression analyses }\end{array}$} & \multirow{2}{*}{$\begin{array}{c}\text { Information on } \\
\text { streamgages } \\
\text { with } \\
\text { significant } \\
\text { leverage }\end{array}$} & \multicolumn{3}{|c|}{$\begin{array}{l}\text { Information on streamgages } \\
\text { with significant influence for } \\
\text { the percentage AEP } \\
\text { regression analyses }\end{array}$} & \multirow{2}{*}{$\begin{array}{c}\text { Information on } \\
\text { streamgages } \\
\text { with } \\
\text { significant } \\
\text { leverage }\end{array}$} & \multicolumn{3}{|c|}{$\begin{array}{l}\text { Information on streamgages } \\
\text { with significant influence for } \\
\text { the percentage AEP } \\
\text { regression analyses }\end{array}$} \\
\hline & & $10 \%$ & $4 \%$ & $1 \%$ & & $10 \%$ & $4 \%$ & $1 \%$ & & $10 \%$ & $4 \%$ & $1 \%$ \\
\hline \multicolumn{13}{|c|}{ Montana streamgages (all hydrologic regions combined) included in the regional regression analyses (Sando, R., and others, 2018) } \\
\hline NA & \multicolumn{4}{|c|}{537 streamgages summarized } & \multicolumn{4}{|c|}{236 streamgages summarized } & \multicolumn{4}{|c|}{301 streamgages summarized } \\
\hline $\begin{array}{l}\text { Number of streamgages } \\
\text { with significance }\end{array}$ & 44 & 49 & 54 & 56 & 19 & 12 & 15 & 15 & 25 & 37 & 39 & 41 \\
\hline $\begin{array}{l}\text { Percentage of streamgages } \\
\text { with significance }\end{array}$ & 8.2 & 9.1 & 10.1 & 10.4 & 8.1 & 5.1 & 6.4 & 6.4 & 8.3 & 12.3 & 13.0 & 13.6 \\
\hline \multicolumn{13}{|c|}{ Active Montana streamgages (all hydrologic regions combined) included in the regional regression analyses (Sando, R., and others, 2018) } \\
\hline NA & \multicolumn{4}{|c|}{162 streamgages summarized } & \multicolumn{4}{|c|}{86 streamgages summarized } & \multicolumn{4}{|c|}{76 streamgages summarized } \\
\hline $\begin{array}{l}\text { Number of streamgages } \\
\text { with significance }\end{array}$ & 20 & 19 & 18 & 22 & 12 & 5 & 6 & 8 & 8 & 14 & 12 & 14 \\
\hline $\begin{array}{l}\text { Percentage of streamgages } \\
\text { with significance }\end{array}$ & 12.3 & 11.7 & 11.1 & 13.6 & 14.0 & 5.8 & 7.0 & 9.3 & 10.5 & 18.4 & 15.8 & 18.4 \\
\hline \multicolumn{13}{|c|}{ Streamgages in the West hydrologic region included in the regional regression analyses (Sando, R., and others, 2018) } \\
\hline NA & \multicolumn{4}{|c|}{113 streamgages summarized } & \multicolumn{4}{|c|}{62 streamgages summarized } & \multicolumn{4}{|c|}{51 streamgages summarized } \\
\hline $\begin{array}{l}\text { Number of streamgages } \\
\text { with significance }\end{array}$ & 9 & 12 & 12 & 12 & 5 & 4 & 3 & 4 & 4 & 8 & 9 & 8 \\
\hline $\begin{array}{l}\text { Percentage of streamgages } \\
\text { with significance }\end{array}$ & 8.0 & 10.6 & 10.6 & 10.6 & 8.1 & 6.5 & 4.8 & 6.5 & 7.8 & 15.7 & 17.6 & 15.7 \\
\hline \multicolumn{13}{|c|}{ Active streamgages in the West hydrologic region included in the regional regression analyses (Sando, R., and others, 2018) } \\
\hline NA & \multicolumn{4}{|c|}{29 streamgages summarized } & \multicolumn{4}{|c|}{29 streamgages summarized } & \multicolumn{4}{|c|}{0 streamgages summarized } \\
\hline $\begin{array}{l}\text { Number of streamgages } \\
\text { with significance }\end{array}$ & 4 & 2 & 2 & 3 & 4 & 2 & 2 & 3 & 0 & 0 & 0 & 0 \\
\hline $\begin{array}{l}\text { Percentage of streamgages } \\
\text { with significance }\end{array}$ & 13.8 & 6.9 & 6.9 & 10.3 & 13.8 & 6.9 & 6.9 & 10.3 & 0.0 & 0.0 & 0.0 & 0.0 \\
\hline \multicolumn{13}{|c|}{ Streamgages in the Northwest hydrologic region included in the regional regression analyses (Sando, R., and others, 2018) } \\
\hline NA & \multicolumn{4}{|c|}{32 streamgages summarized } & \multicolumn{4}{|c|}{26 streamgages summarized } & \multicolumn{4}{|c|}{6 streamgages summarized } \\
\hline $\begin{array}{l}\text { Number of streamgages } \\
\text { with significance }\end{array}$ & 4 & 2 & 4 & 2 & 3 & 1 & 3 & 1 & 4 & 1 & 1 & 1 \\
\hline $\begin{array}{l}\text { Percentage of streamgages } \\
\text { with significance }\end{array}$ & 12.5 & 6.3 & 12.5 & 6.3 & 11.5 & 3.8 & 11.5 & 3.8 & 66.7 & 16.7 & 16.7 & 16.7 \\
\hline
\end{tabular}


Table 7. Information on streamgages with significant leverage and influence statistics from regional regression analyses (Sando, R., and others, 2018).-Continued

[AEP, annual exceedance probability; \%, percent; NA, not applicable]

\begin{tabular}{|c|c|c|c|c|c|c|c|c|c|c|c|c|}
\hline \multirow{3}{*}{ Summary statistic } & \multicolumn{4}{|c|}{$\begin{array}{l}\text { Information for all streamgages (both continuous } \\
\text { streamgages and crest-stage gages) }\end{array}$} & \multicolumn{4}{|c|}{ Information for continuous streamgages } & \multicolumn{4}{|c|}{ Information for crest-stage gages } \\
\hline & \multirow{2}{*}{$\begin{array}{l}\text { Information on } \\
\text { streamgages } \\
\text { with } \\
\text { significant } \\
\text { leverage }\end{array}$} & \multicolumn{3}{|c|}{$\begin{array}{l}\text { Information on streamgages } \\
\text { with significant influence for } \\
\text { the percentage AEP } \\
\text { regression analyses }\end{array}$} & \multirow{2}{*}{$\begin{array}{l}\text { Information on } \\
\text { streamgages } \\
\text { with } \\
\text { significant } \\
\text { leverage }\end{array}$} & \multicolumn{3}{|c|}{$\begin{array}{l}\text { Information on streamgages } \\
\text { with significant influence for } \\
\text { the percentage AEP } \\
\text { regression analyses }\end{array}$} & \multirow{2}{*}{$\begin{array}{l}\text { Information on } \\
\text { streamgages } \\
\text { with } \\
\text { significant } \\
\text { leverage }\end{array}$} & \multicolumn{3}{|c|}{$\begin{array}{l}\text { Information on streamgages } \\
\text { with significant influence for } \\
\text { the percentage AEP } \\
\text { regression analyses }\end{array}$} \\
\hline & & $10 \%$ & $4 \%$ & $1 \%$ & & $10 \%$ & $4 \%$ & $1 \%$ & & $10 \%$ & $4 \%$ & $1 \%$ \\
\hline \multicolumn{13}{|c|}{ Active streamgages in the Northwest hydrologic region included in the regional regression analyses (Sando, R., and others, 2018) } \\
\hline NA & \multicolumn{4}{|c|}{8 streamgages summarized } & \multicolumn{4}{|c|}{8 streamgages summarized } & \multicolumn{4}{|c|}{0 streamgages summarized } \\
\hline $\begin{array}{l}\text { Number of streamgages } \\
\text { with significance }\end{array}$ & 4 & 2 & 4 & 2 & 4 & 1 & 3 & 1 & 0 & 0 & 0 & 0 \\
\hline $\begin{array}{l}\text { Percentage of streamgages } \\
\text { with significance }\end{array}$ & 50.0 & 25.0 & 50.0 & 25.0 & 50.0 & 12.5 & 37.5 & 12.5 & 0.0 & 0.0 & 0.0 & 0.0 \\
\hline \multicolumn{13}{|c|}{ Streamgages in the Northwest Foothills hydrologic region included in the regional regression analyses (Sando, R., and others, 2018) } \\
\hline NA & \multicolumn{4}{|c|}{31 streamgages summarized } & \multicolumn{4}{|c|}{11 streamgages summarized } & \multicolumn{4}{|c|}{20 streamgages summarized } \\
\hline $\begin{array}{l}\text { Number of streamgages } \\
\text { with significance }\end{array}$ & 3 & 2 & 2 & 3 & 2 & 1 & 1 & 1 & 1 & 1 & 1 & 2 \\
\hline $\begin{array}{l}\text { Percentage of streamgages } \\
\text { with significance }\end{array}$ & 9.7 & 6.5 & 6.5 & 9.7 & 18.2 & 9.1 & 9.1 & 9.1 & 5.0 & 5.0 & 5.0 & 10.0 \\
\hline \multicolumn{13}{|c|}{ Active streamgages in the Northwest Foothills hydrologic region included in the regional regression analyses (Sando, R., and others, 2018) } \\
\hline NA & \multicolumn{4}{|c|}{9 streamgages summarized } & \multicolumn{4}{|c|}{5 streamgages summarized } & \multicolumn{4}{|c|}{4 streamgages summarized } \\
\hline $\begin{array}{l}\text { Number of streamgages } \\
\text { with significance }\end{array}$ & 3 & 0 & 0 & 1 & 2 & 0 & 0 & 0 & 1 & 0 & 0 & 1 \\
\hline $\begin{array}{l}\text { Percentage of streamgages } \\
\text { with significance }\end{array}$ & 33.3 & 0.0 & 0.0 & 11.1 & 40.0 & 0.0 & 0.0 & 0.0 & 25.0 & 0.0 & 0.0 & 25.0 \\
\hline \multicolumn{13}{|c|}{ Streamgages in the Northeast Plains hydrologic region included in the regional regression analyses (Sando, R., and others, 2018) } \\
\hline NA & \multicolumn{4}{|c|}{64 streamgages summarized } & \multicolumn{4}{|c|}{33 streamgages summarized } & \multicolumn{4}{|c|}{31 streamgages summarized } \\
\hline $\begin{array}{l}\text { Number of streamgages } \\
\text { with significance }\end{array}$ & 6 & 8 & 7 & 7 & 5 & 2 & 1 & 2 & 1 & 6 & 6 & 5 \\
\hline $\begin{array}{l}\text { Percentage of streamgages } \\
\text { with significance }\end{array}$ & 9.4 & 12.5 & 10.9 & 10.9 & 15.2 & 6.1 & 3.0 & 6.1 & 3.2 & 19.4 & 19.4 & 16.1 \\
\hline \multicolumn{13}{|c|}{ Active streamgages in the Northeast Plains hydrologic region included in the regional regression analyses (Sando, R., and others, 2018) } \\
\hline NA & \multicolumn{4}{|c|}{21 streamgages summarized } & \multicolumn{4}{|c|}{8 streamgages summarized } & \multicolumn{4}{|c|}{13 streamgages summarized } \\
\hline $\begin{array}{l}\text { Number of streamgages } \\
\text { with significance }\end{array}$ & 3 & 5 & 5 & 6 & 2 & 1 & 1 & 2 & 1 & 4 & 4 & 4 \\
\hline $\begin{array}{l}\text { Percentage of streamgages } \\
\text { with significance }\end{array}$ & 14.3 & 23.8 & 23.8 & 28.6 & 25.0 & 12.5 & 12.5 & 25.0 & 7.7 & 30.8 & 30.8 & 30.8 \\
\hline
\end{tabular}


Table 7. Information on streamgages with significant leverage and influence statistics from regional regression analyses (Sando, R., and others, 2018).-Continued

[AEP, annual exceedance probability; \%, percent; NA, not applicable]

\begin{tabular}{|c|c|c|c|c|c|c|c|c|c|c|c|c|}
\hline \multirow{3}{*}{ Summary statistic } & \multicolumn{4}{|c|}{$\begin{array}{c}\text { Information for all streamgages (both continuous } \\
\text { streamgages and crest-stage gages) }\end{array}$} & \multicolumn{4}{|c|}{ Information for continuous streamgages } & \multicolumn{4}{|c|}{ Information for crest-stage gages } \\
\hline & \multirow{2}{*}{$\begin{array}{c}\text { Information on } \\
\text { streamgages } \\
\text { with } \\
\text { significant } \\
\text { leverage }\end{array}$} & \multicolumn{3}{|c|}{$\begin{array}{l}\text { Information on streamgages } \\
\text { with significant influence for } \\
\text { the percentage AEP } \\
\text { regression analyses }\end{array}$} & \multirow{2}{*}{$\begin{array}{c}\text { Information on } \\
\text { streamgages } \\
\text { with } \\
\text { significant } \\
\text { leverage }\end{array}$} & \multicolumn{3}{|c|}{$\begin{array}{l}\text { Information on streamgages } \\
\text { with significant influence for } \\
\text { the percentage AEP } \\
\text { regression analyses }\end{array}$} & \multirow{2}{*}{$\begin{array}{l}\text { Information on } \\
\text { streamgages } \\
\text { with } \\
\text { significant } \\
\text { leverage }\end{array}$} & \multicolumn{3}{|c|}{$\begin{array}{l}\text { Information on streamgages } \\
\text { with significant influence for } \\
\text { the percentage AEP } \\
\text { regression analyses }\end{array}$} \\
\hline & & $10 \%$ & $4 \%$ & $1 \%$ & & $10 \%$ & $4 \%$ & $1 \%$ & & $10 \%$ & $4 \%$ & $1 \%$ \\
\hline \multicolumn{13}{|c|}{ Streamgages in the East-Central Plains hydrologic region included in the regional regression analyses (Sando, R., and others, 2018) } \\
\hline NA & \multicolumn{4}{|c|}{90 streamgages summarized } & \multicolumn{4}{|c|}{16 streamgages summarized } & \multicolumn{4}{|c|}{74 streamgages summarized } \\
\hline $\begin{array}{l}\text { Number of streamgages } \\
\text { with significance }\end{array}$ & 7 & 6 & 7 & 9 & 2 & 1 & 2 & 2 & 5 & 5 & 5 & 7 \\
\hline $\begin{array}{l}\text { Percentage of streamgages } \\
\text { with significance }\end{array}$ & 7.8 & 6.7 & 7.8 & 10.0 & 12.5 & 6.3 & 12.5 & 12.5 & 6.8 & 6.8 & 6.8 & 9.5 \\
\hline \multicolumn{13}{|c|}{ Active streamgages in the East-Central Plains hydrologic region included in the regional regression analyses (Sando, R., and others, 2018) } \\
\hline NA & \multicolumn{4}{|c|}{27 streamgages summarized } & \multicolumn{4}{|c|}{2 streamgages summarized } & \multicolumn{4}{|c|}{25 streamgages summarized } \\
\hline $\begin{array}{l}\text { Number of streamgages } \\
\text { with significance }\end{array}$ & 1 & 2 & 1 & 2 & 0 & 0 & 0 & 0 & 1 & 2 & 1 & 2 \\
\hline $\begin{array}{l}\text { Percentage of streamgages } \\
\text { with significance }\end{array}$ & 3.7 & 7.4 & 3.7 & 7.4 & 0.0 & 0.0 & 0.0 & 0.0 & 4.0 & 8.0 & 4.0 & 8.0 \\
\hline \multicolumn{13}{|c|}{ Streamgages in the Southeast Plains hydrologic region included in the regional regression analyses (Sando, R., and others, 2018) } \\
\hline NA & \multicolumn{4}{|c|}{68 streamgages summarized } & \multicolumn{4}{|c|}{14 streamgages summarized } & \multicolumn{4}{|c|}{54 streamgages summarized } \\
\hline $\begin{array}{l}\text { Number of streamgages } \\
\text { with significance }\end{array}$ & 4 & 8 & 10 & 10 & 1 & 2 & 5 & 4 & 3 & 6 & 5 & 6 \\
\hline $\begin{array}{l}\text { Percentage of streamgages } \\
\text { with significance }\end{array}$ & 5.9 & 11.8 & 14.7 & 14.7 & 7.1 & 14.3 & 35.7 & 28.6 & 5.6 & 11.1 & 9.3 & 11.1 \\
\hline \multicolumn{13}{|c|}{ Active streamgages in the Southeast Plains hydrologic region included in the regional regression analyses (Sando, R., and others, 2018) } \\
\hline NA & \multicolumn{4}{|c|}{27 streamgages summarized } & \multicolumn{4}{|c|}{5 streamgages summarized } & \multicolumn{4}{|c|}{22 streamgages summarized } \\
\hline $\begin{array}{l}\text { Number of streamgages } \\
\text { with significance }\end{array}$ & 3 & 6 & 5 & 5 & 1 & 2 & 2 & 2 & 2 & 4 & 3 & 3 \\
\hline $\begin{array}{l}\text { Percentage of streamgages } \\
\text { with significance }\end{array}$ & 11.1 & 22.2 & 18.5 & 18.5 & 20.0 & 40.0 & 40.0 & 40.0 & 9.1 & 18.2 & 13.6 & 13.6 \\
\hline \multicolumn{13}{|c|}{ Streamgages in the Upper Yellowstone-Central Mountain hydrologic region included in the regional regression analyses (Sando, R., and others, 2018) } \\
\hline NA & \multicolumn{4}{|c|}{91 streamgages summarized } & \multicolumn{4}{|c|}{50 streamgages summarized } & \multicolumn{4}{|c|}{41 streamgages summarized } \\
\hline $\begin{array}{l}\text { Number of streamgages } \\
\text { with significance }\end{array}$ & 10 & 12 & 13 & 13 & 3 & 2 & 3 & 2 & 7 & 10 & 10 & 11 \\
\hline $\begin{array}{l}\text { Percentage of streamgages } \\
\text { with significance }\end{array}$ & 11.0 & 13.2 & 14.3 & 14.3 & 6.0 & 4.0 & 6.0 & 4.0 & 17.1 & 24.4 & 24.4 & 26.8 \\
\hline
\end{tabular}


Table 7. Information on streamgages with significant leverage and influence statistics from regional regression analyses (Sando, R., and others, 2018).-Continued

[AEP, annual exceedance probability; \%, percent; NA, not applicable]

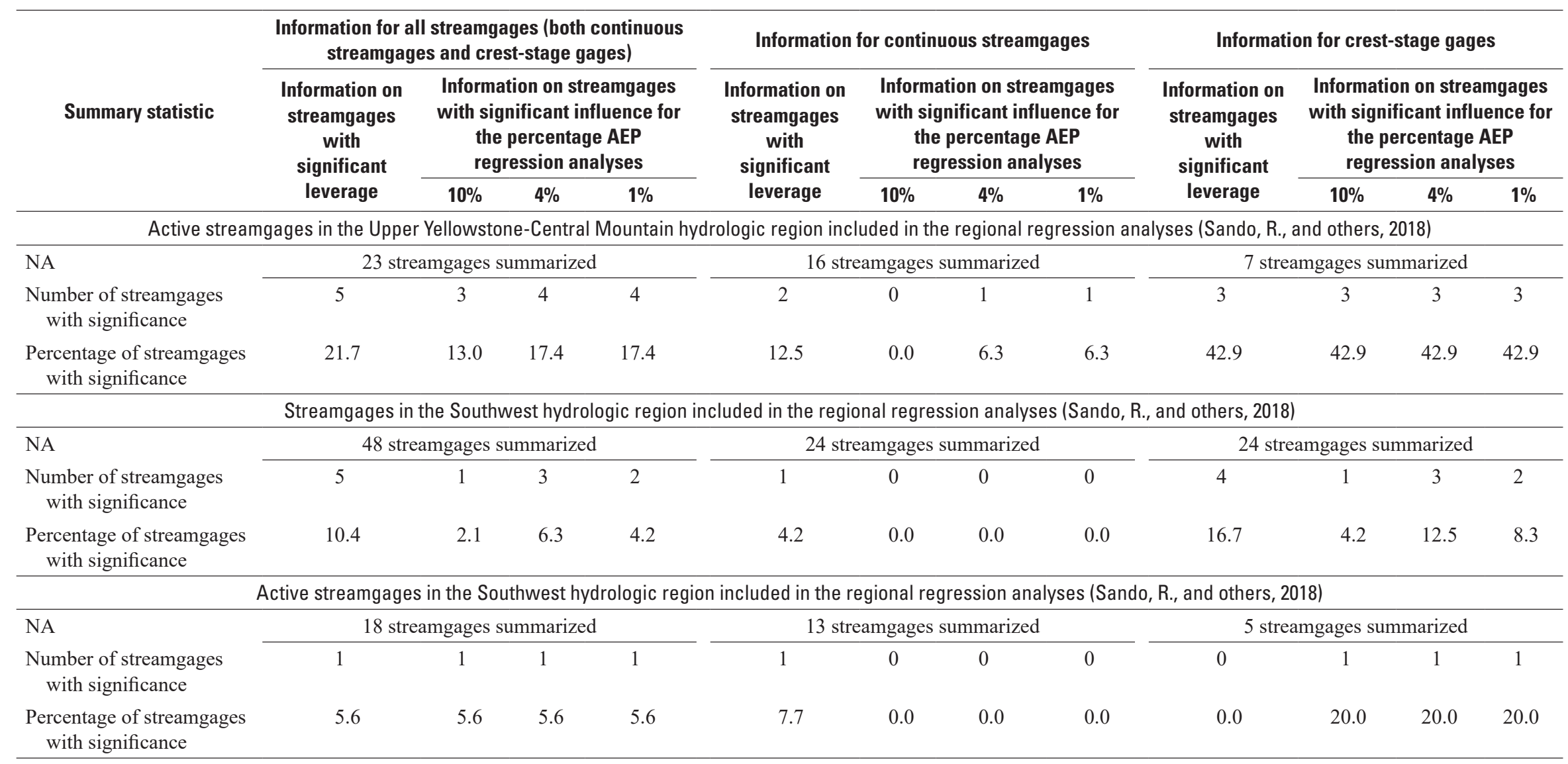




\section{Description of Peak-Flow Variability and Peak-Flow Informational Needs, and Consideration of Regional Regression Analyses by Hydrologic Region}

In the sections "Peak-Flow Variability in Montana," "General Characterization of Peak-Flow Informational Needs in Montana," and "Consideration of Regional Regression Analyses in Managing the Crest-Stage Gage Network," various datasets were investigated on a statewide basis with a primary conclusion that individual hydrologic regions substantially differ from statewide patterns and among each other. The following sections discuss peak-flow variability and informational needs, and regional regression analyses for each hydrologic region. In the discussion, comparisons are made between the characteristics for each hydrologic region and statewide patterns. The comparisons might be useful in identifying hydroclimatic settings needing more and less representation in the statewide CSG network.

In support of some of the discussion for the hydrologic regions, table 8 presents statistical summaries of precipitation characteristics for the drainage basins of unregulated streamgages in the hydrologic regions. Also, tables 9-11 presents statistical summaries of selected streamgage characteristics and drainage-basin characteristics for streamgages included in regional regression analyses (Sando, R., and others, 2018).

\section{Peak-Flow Variability, Peak-Flow Informational Needs, and Consideration of Regional Regression Analyses in the West Hydrologic Region}

The West hydrologic region has an area of $21,371 \mathrm{mi}^{2}$ (table 1), which ranks fourth largest among the eight hydrologic regions. Level III ecoregions (table 2) represented in the West hydrologic region include the Canadian Rockies (9.5 percent), Idaho Batholith (8.2 percent), Middle Rockies (29.9 percent), and Northern Rockies (52.5 percent). The 2,380 road and stream intersections in the West hydrologic region (tables 4 and 5) represent a density of 0.111 road and stream intersection per $\mathrm{mi}^{2}$, which ranks second among the hydrologic regions. The 141 streamgages (both regulated and unregulated; tables 4 and 5) represent an areal density of 0.00660 streamgage per $\mathrm{mi}^{2}$ (ranking first among hydrologic regions) and a density of 0.05924 streamgage per road and stream intersection (ranking fourth among hydrologic regions).

Relations between $P F V I$ and contributing drainage area, mean basin elevation, mean annual precipitation, and years of peak-flow records for 133 unregulated streamgages in the
West hydrologic region (table 3 ) are presented in figure 6. For the 133 unregulated streamgages, $P F V I$ generally monotonically decreases with increasing drainage area (fig. $6 A$ ) with generally small and consistent variability about the LOWESS line. Intuitively, highly variable small-scale hydroclimatic processes are integrated with increasing drainage area such that variability in many hydrologic characteristics is reduced. PFVI also decreases with increasing elevation (fig. $6 B$ ), precipitation (fig. 6C), and years of record (fig. $6 D$ ). For the relations between $P F V I$ and drainage area (fig. $6 A$ ), elevation (fig. $6 B$ ), and years of record (fig. $6 D$ ), the LOWESS lines for the West hydrologic region are consistently below the LOWESS lines for all unregulated streamgages in Montana.

Relations between contributing drainage area and mean basin elevation, mean annual precipitation, and years of peakflow records for the unregulated streamgages are presented in figure 7. Streamgages with greater than about 50 years of record are predominantly located on streams with contributing drainage areas greater than about $100 \mathrm{mi}^{2}$ (fig. 7C), which likely strongly contributes to the $P F V I$ and years of record relations (fig. 6D).

The median PFVI value for streamgages in the West hydrologic region $(7.63$, table 3$)$ is substantially less than the median for all unregulated streamgages in Montana (18.26, table 3) and ranks as the seventh largest median PFVI among the eight hydrologic regions. A major factor contributing to low peak-flow variability in the West hydrologic region might be the strong dominance of snowmelt runoff in the annual hydrograph of the streamgages. For unregulated streamgages in the West hydrologic region, fall and winter (OctoberFebruary) precipitation accounts for about 40 percent of annual precipitation (table 8), which can result in large accumulated snowpacks (Sando and McCarthy, 2018) that contribute to streamflows during the typical snowmelt runoff period of May through mid-July. May-June precipitation accounts for about 24.4 percent of annual precipitation (table 8), which ranks eighth among the hydrologic regions, and July-August precipitation accounts for 13.3 percent of annual precipitation, which ranks seventh among the eight hydrologic regions. In the West hydrologic region, annual peak flows predominantly are in May and June (fig. 2 of Sando, R., and others, 2018). Dominance of snowmelt in the annual hydrograph tends to provide temporal integration of a substantial part of the annual precipitation inputs and contributes to the low PFVIs for streamgages in the West hydrologic region.

Although streamgages in the West hydrologic region have less than typical PFVIs, about 12.5 percent of the streamgages are considered to have mixed-population characteristics (table 1) that result in a small number of unusually large peak flows that are substantially larger than the main body of peak flows. Typically, the unusually large peak-flow events result from extremely intense rainfall events in May and June that happen near the peak of snowmelt runoff. Mixed-population peak-flow datasets often are in streamgages with drainage basins along or near the Continental Divide. In other areas of the West hydrologic region, some mixed-population peak-flow 
Table 8. Statistical summaries of precipitation characteristics for the drainage basins of unregulated streamgages in the hydrologic regions in Montana.

$[n$, number of unregulated streamgages $]$

\begin{tabular}{|c|c|c|c|c|c|c|c|c|c|c|c|c|c|c|c|c|c|c|c|}
\hline \multirow{2}{*}{$\begin{array}{l}\text { Hydrologic } \\
\text { region } \\
\text { (ordered } \\
\text { clockwise from } \\
\text { northwestern } \\
\text { Montana) }\end{array}$} & \multirow{2}{*}{$\begin{array}{l}\text { Hydrologic } \\
\text { region } \\
\text { number } \\
\text { (fig. 1) }\end{array}$} & \multirow{2}{*}{$n$} & \multicolumn{16}{|c|}{$\begin{array}{l}\text { Mean percentage of annual precipitation that occurs in each month or selected groups of months } \\
\text { for the drainage basins of unregulated streamgages }\end{array}$} & \multirow{2}{*}{$\begin{array}{c}\text { Mean } \\
\text { (1981-2010) } \\
\text { annual } \\
\text { precipitation, } \\
\text { in inches }{ }^{1}\end{array}$} \\
\hline & & & Oct. & Nov. & Dec. & Jan. & Feb. & Mar. & Apr. & May & June & July & Aug. & Sept. & $\begin{array}{l}\text { Oct.- } \\
\text { Feb. }\end{array}$ & $\begin{array}{l}\text { Feb.- } \\
\text { Apr. }\end{array}$ & $\begin{array}{l}\text { May- } \\
\text { June }\end{array}$ & $\begin{array}{l}\text { July- } \\
\text { Aug. }\end{array}$ & \\
\hline West & 1 & 133 & 7.1 & 9.7 & 8.8 & 8.2 & 6.4 & 7.1 & 7.5 & 11.5 & 12.9 & 6.9 & 6.4 & 7.3 & 40.3 & 21.1 & 24.4 & 13.3 & 19.3 \\
\hline Northwest & 2 & 44 & 6.8 & 9.0 & 7.9 & 8.0 & 6.1 & 7.7 & 7.8 & 11.7 & 13.6 & 6.8 & 6.3 & 8.2 & 37.8 & 21.6 & 25.4 & 13.1 & 29.0 \\
\hline $\begin{array}{l}\text { Northwest } \\
\text { Foothills }\end{array}$ & 3 & 40 & 5.5 & 3.6 & 3.0 & 2.8 & 2.5 & 5.4 & 8.8 & 16.3 & 20.4 & 10.5 & 10.6 & 10.6 & 17.5 & 16.6 & 36.7 & 21.1 & 12.4 \\
\hline Northeast Plains & 4 & 76 & 5.9 & 3.9 & 3.2 & 3.4 & 2.2 & 4.3 & 7.0 & 16.3 & 20.8 & 14.1 & 9.4 & 9.4 & 18.7 & 13.6 & 37.1 & 23.5 & 12.9 \\
\hline $\begin{array}{l}\text { East-Central } \\
\text { Plains }\end{array}$ & 5 & 102 & 7.1 & 3.2 & 2.8 & 2.7 & 1.9 & 4.5 & 8.7 & 17.0 & 19.4 & 14.8 & 9.1 & 8.9 & 17.7 & 15.1 & 36.4 & 23.9 & 12.6 \\
\hline Southeast Plains & 6 & 74 & 8.3 & 3.9 & 3.0 & 2.9 & 2.5 & 5.8 & 10.2 & 17.0 & 17.7 & 12.4 & 7.4 & 8.9 & 20.7 & 18.6 & 34.6 & 19.8 & 13.6 \\
\hline $\begin{array}{l}\text { Upper } \\
\text { Yellowstone- } \\
\text { Central } \\
\text { Mountain }\end{array}$ & 7 & 108 & 7.9 & 4.8 & 4.2 & 3.7 & 3.5 & 6.5 & 10.5 & 16.8 & 16.1 & 9.9 & 7.6 & 8.5 & 24.1 & 20.5 & 32.9 & 17.5 & 16.4 \\
\hline Southwest & 8 & 67 & 7.0 & 5.3 & 4.7 & 4.2 & 3.7 & 6.0 & 9.7 & 16.0 & 16.6 & 9.8 & 8.8 & 8.3 & 24.8 & 19.4 & 32.6 & 18.6 & 14.5 \\
\hline
\end{tabular}

${ }^{1}$ Precipitation variables determined from geospatial analysis of climatic datasets obtained from Parameter-elevation Regression on Independent Slopes Model (PRISM) data (PRISM Climate Group, 2004). 
Table 9. Statistical summaries of selected streamgage characteristics and drainage-basin characteristics for all streamgages (both continuous streamgages and crest-stage gages) included in the Montana regional regression analyses (Sando, R., and others, 2018).

[No., number; PFVI, peak-flow variability index calculated by 100 times the standard deviation of the peak flows (base-10 logarithms) divided by the mean of the peak flows (base-10 logarithms); the standard deviations and means of the peak flows were calculated using Bulletin 17B procedures (U.S. Interagency Advisory Council on Water Data, 1982) for fitting the log-Pearson III distribution. CONTDA, contributing drainage area, in square miles; $E L_{5000}$, percentage of basin above 5,000 feet elevation; $E L_{6000}$, percentage of basin above 6,000 feet elevation; $S L O P 30 \_30 M$, percentage of basin with slopes greater than or equal to 30 percent; $P R E$ $C I P$, mean annual precipitation, in inches; ET0306MOD, spring mean monthly evapotranspiration, in inches per month; FOREST, Percent of basin in forest]

\begin{tabular}{|c|c|c|c|c|c|c|c|c|c|}
\hline \multirow{3}{*}{$\begin{array}{c}\text { Summary } \\
\text { statistic }\end{array}$} & \multicolumn{9}{|c|}{ Statistical summaries for all streamgages (both continuous streamgages and crest-stage gages) } \\
\hline & \multicolumn{2}{|c|}{$\begin{array}{c}\text { Streamgage } \\
\text { characteristics }\end{array}$} & \multicolumn{7}{|c|}{ Basin and climatic used as explanatory variables in regional regression equations } \\
\hline & No. & PFVI & CONTDA & $E L_{5000}$ & $E L_{6000}$ & SLOP30_30M & PRECIP & ET0306MOD & FOREST \\
\hline \multicolumn{10}{|c|}{ Summary statistics for streamgages in Montana } \\
\hline \multicolumn{10}{|c|}{537 streamgages summarized } \\
\hline 90th percentile ${ }^{1}$ & 56 & 71.88 & 528.60 & 100.00 & 79.46 & 66.37 & 39.94 & 1.79 & 84.96 \\
\hline \multicolumn{10}{|c|}{ Summary statistics for active streamgages in Montana } \\
\hline \multicolumn{10}{|c|}{162 streamgages summarized } \\
\hline 10th percentile 1 & 31 & 4.94 & 1.40 & 0.00 & 0.00 & 0.00 & 12.94 & 1.02 & 0.00 \\
\hline \multicolumn{10}{|c|}{ Summary statistics for streamgages in the West hydrologic region } \\
\hline \multicolumn{10}{|c|}{113 streamgages summarized } \\
\hline 10th percentile 1 & 10 & 4.04 & 3.76 & 19.77 & 0.50 & 25.71 & 21.62 & 1.60 & 55.42 \\
\hline Median & 20 & 8.01 & 28.90 & 56.90 & 24.15 & 55.91 & 33.04 & 1.73 & 80.08 \\
\hline 90th percentile ${ }^{1}$ & 57 & 24.35 & 576.40 & 94.57 & 70.34 & 80.01 & 50.22 & 1.89 & 92.85 \\
\hline \multicolumn{10}{|c|}{ Summary statistics for active streamgages in the West hydrologic region } \\
\hline \multicolumn{10}{|c|}{29 streamgages summarized } \\
\hline 10th percentile ${ }^{1}$ & 19 & 4.63 & 50.00 & 27.63 & 3.88 & 24.93 & 19.44 & 1.59 & 47.99 \\
\hline Median & 44 & 6.57 & 419.00 & 80.00 & 41.50 & 42.84 & 29.56 & 1.72 & 72.36 \\
\hline 90th percentile ${ }^{1}$ & 80 & 11.06 & $1,010.80$ & 98.13 & 78.42 & 73.88 & 44.61 & 1.83 & 92.41 \\
\hline \multicolumn{10}{|c|}{8 streamgages summarized } \\
\hline 10th percentile ${ }^{1}$ & 33 & 2.94 & 51.92 & 49.42 & 21.74 & 32.02 & 31.74 & 1.60 & 26.88 \\
\hline Median & 64 & 4.63 & 206.00 & 78.34 & 49.41 & 59.09 & 41.57 & 1.73 & 69.44 \\
\hline 90th percentile ${ }^{1}$ & 98 & 14.43 & $1,278.10$ & 98.21 & 69.80 & 73.58 & 59.89 & 1.82 & 78.45 \\
\hline \multicolumn{10}{|c|}{ Summary statistics for streamgages in the Northwest Foothills hydrologic region } \\
\hline \multicolumn{10}{|c|}{31 streamgages summarized } \\
\hline 10th percentile 1 & 15 & 14.61 & 0.72 & 0.00 & 0.00 & 0.00 & 11.94 & 1.08 & 0.00 \\
\hline Median & 18 & 38.87 & 14.40 & 0.00 & 0.00 & 0.28 & 13.20 & 1.22 & 0.00 \\
\hline 90th percentile ${ }^{1}$ & 62 & 89.31 & 405.00 & 27.82 & 11.47 & 11.48 & 20.55 & 1.51 & 10.75 \\
\hline
\end{tabular}


Table 9. Statistical summaries of selected streamgage characteristics and drainage-basin characteristics for all streamgages (both continuous streamgages and crest-stage gages) included in the Montana regional regression analyses (Sando, R., and others, 2018).Continued

[No., number; PFVI, peak-flow variability index calculated by 100 times the standard deviation of the peak flows (base-10 logarithms) divided by the mean of the peak flows (base-10 logarithms); the standard deviations and means of the peak flows were calculated using Bulletin 17B procedures (U.S. Interagency Advisory Council on Water Data, 1982) for fitting the log-Pearson III distribution. CONTDA, contributing drainage area, in square miles; $E L_{5000}$, percentage of basin above 5,000 feet elevation; $E L_{6000}$, percentage of basin above 6,000 feet elevation; $S L O P 30 \_30 M$, percentage of basin with slopes greater than or equal to 30 percent; PRE$C I P$, mean annual precipitation, in inches; ET0306MOD, spring mean monthly evapotranspiration, in inches per month; FOREST, Percent of basin in forest]

\begin{tabular}{|c|c|c|c|c|c|c|c|c|c|}
\hline \multirow[b]{2}{*}{$\begin{array}{l}\text { Summary } \\
\text { statistic }\end{array}$} & \multicolumn{9}{|c|}{ Statistical summaries for all streamgages (both continuous streamgages and crest-stage gages) } \\
\hline & \multicolumn{2}{|c|}{$\begin{array}{c}\text { Streamgage } \\
\text { characteristics }\end{array}$} & \multicolumn{7}{|c|}{ Basin and climatic used as explanatory variables in regional regression equations } \\
\hline \multicolumn{10}{|c|}{ Summary statistics for active streamgages in the Northwest Foothills hydrologic region } \\
\hline \multicolumn{10}{|c|}{9 streamgages summarized } \\
\hline 90th percentile ${ }^{1}$ & 81 & 56.25 & $1,073.20$ & 34.64 & 14.71 & 17.47 & 23.19 & 1.51 & 17.15 \\
\hline \multicolumn{10}{|c|}{ Summary statistics for streamgages in the Northeast Plains hydrologic region } \\
\hline \multicolumn{10}{|c|}{64 streamgages summarized } \\
\hline 10th percentile ${ }^{1}$ & 11 & 18.14 & 1.64 & 0.00 & 0.00 & 0.00 & 12.21 & 1.05 & 0.00 \\
\hline \multicolumn{10}{|c|}{21 streamgages summarized } \\
\hline 10th percentile ${ }^{1}$ & 34 & 17.81 & 1.62 & 0.00 & 0.00 & 0.00 & 11.64 & 1.05 & 0.00 \\
\hline Median & 43 & 36.32 & 3.76 & 0.00 & 0.00 & 0.15 & 13.80 & 1.18 & 0.00 \\
\hline 90th percentile ${ }^{1}$ & 50 & 129.45 & $1,199.00$ & 5.79 & 0.00 & 14.45 & 18.76 & 1.42 & 10.23 \\
\hline \multicolumn{10}{|c|}{ Summary statistics for streamgages in the East-Central Plains hydrologic region } \\
\hline \multicolumn{10}{|c|}{90 streamgages summarized } \\
\hline 10th percentile ${ }^{1}$ & 15 & 16.51 & 0.76 & 0.00 & 0.00 & 0.00 & 12.38 & 0.95 & 0.00 \\
\hline Median & 22 & 38.20 & 4.26 & 0.00 & 0.00 & 0.05 & 13.12 & 1.06 & 0.02 \\
\hline 90th percentile ${ }^{1}$ & 51 & 72.31 & 436.70 & 0.00 & 0.00 & 4.33 & 14.48 & 1.21 & 12.75 \\
\hline \multicolumn{10}{|c|}{68 streamgages summarized } \\
\hline 10th percentile ${ }^{1}$ & 15 & 13.84 & 0.81 & 0.00 & 0.00 & 0.00 & 13.84 & 1.03 & 0.00 \\
\hline Median & 30 & 37.29 & 5.78 & 0.00 & 0.00 & 1.46 & 14.83 & 1.21 & 6.74 \\
\hline 90th percentile ${ }^{1}$ & 46 & 98.25 & 672.90 & 0.00 & 0.00 & 13.44 & 16.55 & 1.38 & 26.82 \\
\hline \multicolumn{10}{|c|}{ Summary statistics for active streamgages in the Southeast Plains hydrologic region } \\
\hline \multicolumn{10}{|c|}{27 streamgages summarized } \\
\hline 10th percentile ${ }^{1}$ & 35 & 23.97 & 0.69 & 0.00 & 0.00 & 0.00 & 13.57 & 1.01 & 0.00 \\
\hline Median & 44 & 47.77 & 3.64 & 0.00 & 0.00 & 2.61 & 14.35 & 1.16 & 9.72 \\
\hline 90th percentile ${ }^{1}$ & 54 & 100.28 & 558.60 & 0.00 & 0.00 & 13.63 & 15.93 & 1.37 & 25.15 \\
\hline
\end{tabular}


Table 9. Statistical summaries of selected streamgage characteristics and drainage-basin characteristics for all streamgages (both continuous streamgages and crest-stage gages) included in the Montana regional regression analyses (Sando, R., and others, 2018).Continued

[No., number; PFVI, peak-flow variability index calculated by 100 times the standard deviation of the peak flows (base-10 logarithms) divided by the mean of the peak flows (base-10 logarithms); the standard deviations and means of the peak flows were calculated using Bulletin 17B procedures (U.S. Interagency Advisory Council on Water Data, 1982) for fitting the log-Pearson III distribution. CONTDA, contributing drainage area, in square miles; $E L_{5000}$, percentage of basin above 5,000 feet elevation; $E L_{6000}$, percentage of basin above 6,000 feet elevation; SLOP30_30M, percentage of basin with slopes greater than or equal to 30 percent; PRE$C I P$, mean annual precipitation, in inches; ET0306MOD, spring mean monthly evapotranspiration, in inches per month; FOREST, Percent of basin in forest]

\begin{tabular}{|c|c|c|c|c|c|c|c|c|c|}
\hline \multirow[b]{2}{*}{$\begin{array}{l}\text { Summary } \\
\text { statistic }\end{array}$} & \multicolumn{9}{|c|}{ Statistical summaries for all streamgages (both continuous streamgages and crest-stage gages) } \\
\hline & \multicolumn{2}{|c|}{$\begin{array}{c}\text { Streamgage } \\
\text { characteristics }\end{array}$} & \multicolumn{7}{|c|}{ Basin and climatic used as explanatory variables in regional regression equations } \\
\hline \multicolumn{10}{|c|}{ Summary statistics for streamgages in the Upper Yellowstone-Central Mountain hydrologic region } \\
\hline \multicolumn{10}{|c|}{91 streamgages summarized } \\
\hline 90th percentile ${ }^{1}$ & 68 & 62.17 & 430.00 & 100.00 & 96.94 & 53.28 & 32.93 & 1.79 & 77.61 \\
\hline \multicolumn{10}{|c|}{ Summary statistics for active streamgages in the Upper Yellowstone-Central Mountain hydrologic region } \\
\hline \multicolumn{10}{|c|}{23 streamgages summarized } \\
\hline 10th percentile ${ }^{1}$ & 41 & 3.35 & 3.07 & 6.69 & 0.00 & 0.59 & 17.17 & 1.40 & 0.07 \\
\hline \multicolumn{10}{|c|}{ Summary statistics for streamgages in the Southwest hydrologic region } \\
\hline \multicolumn{10}{|c|}{48 streamgages summarized } \\
\hline 10th percentile ${ }^{1}$ & 15 & 5.67 & 4.36 & 56.60 & 21.96 & 11.85 & 16.31 & 1.31 & 15.45 \\
\hline Median & 24 & 9.33 & 43.50 & 100.00 & 88.12 & 33.48 & 21.81 & 1.47 & 59.32 \\
\hline 90th percentile ${ }^{1}$ & 77 & 73.83 & 404.20 & 100.00 & 100.00 & 50.92 & 31.31 & 1.63 & 86.57 \\
\hline \multicolumn{10}{|c|}{ Summary statistics for active streamgages in the Southwest hydrologic region } \\
\hline \multicolumn{10}{|c|}{18 streamgages summarized } \\
\hline 10th percentile ${ }^{1}$ & 20 & 5.67 & 16.40 & 73.46 & 34.09 & 13.75 & 18.88 & 1.44 & 33.93 \\
\hline Median & 49 & 8.09 & 111.85 & 100.00 & 92.68 & 33.48 & 23.43 & 1.48 & 57.95 \\
\hline 90th percentile ${ }^{1}$ & 91 & 34.95 & 792.70 & 100.00 & 100.00 & 47.92 & 35.37 & 1.64 & 88.63 \\
\hline
\end{tabular}

${ }^{1}$ Nonexceedance percentile.

datasets result from ice jams and associated releases, and unusual rapid snowmelt events during winter, sometimes in association with rainfall. The large peak-flow variability of mixed-population peak-flow datasets might not be well represented in the PFVI values because the unusually large peakflow events are infrequent and might not substantially affect the calculation of the PFVI values. Nearly all (11 out of 12) of the mixed-population streamgages in the West hydrologic region that were included in the regional regression analysis (Sando, R., and others, 2018) had positive residuals for the 1-percent AEP regression; however, none of those mixedpopulation streamgages had significant influence. Among the candidate explanatory variables included in the regional regression analyses, there are no variables that represent spatial variability in precipitation intensity (such as indices of the 100-year 24-hour precipitation; for example, U.S. Weather
Bureau, 1961). Inclusion of variables that represent spatial variability in precipitation intensity might help address some mixed-population issues and improve potential future regional regression analyses in the West hydrologic region.

The CDFs of selected basin characteristics (drainage area, mean basin elevation, and mean annual precipitation) for the road and stream intersections and for the streamgages in the West hydrologic region are shown in figure 8 . With respect to drainage area, the CDF of road and stream intersections for the West hydrologic region generally is similar to the CDF of road and stream intersections for all of Montana (fig. 8A), but with smaller representation of drainage areas between about $1-7 \mathrm{mi}^{2}$. In the West hydrologic region, the CDF of streamgages diverges from the CDF of road and stream intersections in the range of drainage areas less than about $5 \mathrm{mi}^{2}$, indicating underrepresentation of those small drainage areas. 
Mean basin elevation for road and stream intersections in the West hydrologic region ranges from 2,236 to 8,006 feet ( $\mathrm{ft}$; Dutton and others, 2021) with a median of 4,741 ft (table 4), which generally are similar to the range (1,951-9,974 ft; Dutton and others, 2021) and median (4,173 ft; table 4) for all of Montana . However, the West hydrologic region has a somewhat lower proportion of road and stream intersections less than about 4,000 $\mathrm{ft}$ than Montana as a whole (fig. 8B). With respect to mean basin elevation, the pattern of the streamgage CDF reasonably represents the road and stream intersections CDF but with underrepresentation at elevations less than about 4,000 ft. Although about 20 percent of the road and stream intersections have mean basin elevations less than about $4,000 \mathrm{ft}$, only one streamgage falls within that range.

The West hydrologic region is somewhat wetter than Montana as a whole. Mean annual precipitation for road and stream intersections in the West hydrologic region ranges from 10.4 to 75.1 inches (Dutton and others, 2021) with a median of 23.4 inches (table 5). The range for the West hydrologic region is somewhat smaller than for all of Montana (8.4-91.3 inches; Dutton and others, 2021) and the median for the West hydrologic region is larger than for all of Montana (15.7 inches; table 5). The West hydrologic region has a somewhat lower proportion of road and stream intersections with mean annual precipitation less than about 25 inches than Montana as a whole (fig. 8C). With respect to mean annual precipitation, the pattern of the streamgage CDF reasonably represents the road and stream intersections $\mathrm{CDF}$, but the $\mathrm{CDF}$ of streamgages diverges from the CDF of road and stream intersections in the range of mean annual precipitation less than about 25 inches, indicating underrepresentation of drier parts of the West hydrologic region.

The explanatory variables for the West hydrologic region RREs are contributing drainage area (CONTDA), mean annual precipitation (PRECIP), and percentage of basin that is forest (FOREST; table 6). The 1-percent AEP RRE for the West hydrologic region has an SEP of 56.0 percent, which is somewhat less than the area-weighted mean SEP for all hydrologic regions in Montana (63.3 percent; table 6). For the 1-percent AEP regression for the West hydrologic region, 8.0 percent of the streamgages have significant leverage and 10.6 percent of the streamgages have significant influence (table 7); these percentages are similar to significant leverage and influence percentages (8.2 and 10.4 percent, respectively; table 7) for all of the streamgages in Montana used in the regional regression analyses.

Information on streamgages in the West hydrologic region with significant leverage and influence is presented in table 12. All of the nine significant leverage streamgages have low FOREST values (nonexceedance percentiles less than about 10 percent), generally in association with unusually low or high PRECIP values and (or) unusually low or high CONTDA values. Most (six out of nine) of the significant leverage streamgages are in a somewhat small part of the West hydrologic region in the Clark Fork basin upstream from Drummond, Montana. Five of the significant leverage streamgages also have significant influence. The 14 streamgages with significant influence vary with respect to the residuals for the 1-percent AEP RRE; eight of the streamgages have negative residuals, and six have positive residuals. All of the five streamgages with significant leverage and significant influence are in the upper Clark Fork Basin. Two of the streamgages are on main-stem channels with generally large drainage basins and have negative residuals. Three of the streamgages are on tributary channels with generally small drainage basins and have positive residuals.

In general, the streamgage network in the West hydrologic region is considered to provide reasonable representation of the hydroclimatic settings of that hydrologic region. The RREs of the West hydrologic region are considered to be reasonably reliable. Possible shortcomings of the streamgage network in the West hydrologic region include no active CSGs, and possible underrepresentation of basins with drainage area less than about $5 \mathrm{mi}^{2}$, mean elevation less than about $4,000 \mathrm{ft}$, and (or) mean annual precipitation less than about 25 inches. The lack of active CSGs might contribute to poor understanding of effects of future climatic variability on small drainage basins in the West hydrologic region. Future improvements to the streamgage network in the West hydrologic region might include establishing new CSGs or reactivating discontinued streamgages as CSGs on basins with the underrepresented characteristics. Information on discontinued streamgages in the West hydrologic region that might be candidates for reactivation to improve the streamgage network is presented in table 13.

\section{Peak-Flow Variability, Peak-Flow Informational Needs, and Consideration of Regional Regression Analyses in the Northwest Hydrologic Region}

The Northwest hydrologic region has an area of 7,938 $\mathrm{mi}^{2}$ (table 1), which ranks eighth largest among the eight hydrologic regions. Level III ecoregions (table 2) represented in the Northwest hydrologic region include the Canadian Rockies (66.3 percent), Middle Rockies (11.1 percent), and Northwestern Glaciated Plains (22.6 percent). The 356 road and stream intersections in the Northwest hydrologic region (tables 4 and 5) represent a density of 0.045 road and stream intersection per $\mathrm{mi}^{2}$, which ranks eighth among the hydrologic regions. The 49 streamgages (both regulated and unregulated; tables 4 and 5) represent an areal density of 0.00617 streamgage per $\mathrm{mi}^{2}$ (ranking second among hydrologic regions) and a density of 0.13764 streamgage per road and stream intersection (ranking first among hydrologic regions).

Relations between $P F V I$ and contributing drainage area, mean basin elevation, mean annual precipitation, and years of peak-flow records for 44 unregulated streamgages in the Northwest hydrologic region (table 3) are presented in figure 9. In general, the small number of unregulated streamgages in the 
Table 10. Statistical summaries of selected streamgage characteristics and drainage-basin characteristics for continuous streamgages included in the Montana regional regression analyses (Sando, R., and others, 2018).

[PFVI, peak-flow variability index calculated by 100 times the standard deviation of the peak flows (base-10 logarithms) divided by the mean of the peak flows (base-10 logarithms); the standard deviations and means of the peak flows were calculated using Bulletin 17B procedures (U.S. Interagency Advisory Council on Water Data, 1982) for fitting the log-Pearson III distribution. CONTDA, contributing drainage area, in square miles; $E L_{5000}$, percentage of basin above 5,000 feet elevation; $E L_{6000}$, percentage of basin above 6,000 feet elevation; SLOP30_30M, percentage of basin with slopes greater than or equal to 30 percent; PRECIP, mean annual precipitation, in inches; ET0306MOD, spring mean monthly evapotranspiration, in inches per month; FOREST, percentage of basin in forest]

\begin{tabular}{|c|c|c|c|c|c|c|c|c|c|}
\hline \multirow[b]{2}{*}{$\begin{array}{l}\text { Summary } \\
\text { statistic }\end{array}$} & \multicolumn{9}{|c|}{ Statistical summaries for continuous streamgages } \\
\hline & \multicolumn{2}{|c|}{$\begin{array}{c}\text { Streamgage } \\
\text { characteristics }\end{array}$} & \multicolumn{7}{|c|}{ Basin and climatic used as explanatory variables in regional regression equations } \\
\hline \multicolumn{10}{|c|}{ Summary statistics for continuous streamgages in Montana } \\
\hline \multicolumn{10}{|c|}{236 continuous streamgages summarized } \\
\hline 90th percentile ${ }^{1}$ & 78 & 28.50 & $1,102.50$ & 100.00 & 92.10 & 68.32 & 46.91 & 1.79 & 85.23 \\
\hline \multicolumn{10}{|c|}{ Summary statistics for active continuous streamgages in Montana } \\
\hline \multicolumn{10}{|c|}{86 continuous streamgages summarized } \\
\hline 10th percentile ${ }^{1}$ & 24 & 3.74 & 59.20 & 0.00 & 0.00 & 2.04 & 15.04 & 1.28 & 3.24 \\
\hline \multicolumn{10}{|c|}{62 continuous streamgages summarized } \\
\hline 10th percentile ${ }^{1}$ & 10 & 3.73 & 19.73 & 28.00 & 4.03 & 25.94 & 21.30 & 1.61 & 55.41 \\
\hline Median & 24 & 6.58 & 175.00 & 69.37 & 38.07 & 49.43 & 32.64 & 1.73 & 76.48 \\
\hline 90th percentile ${ }^{1}$ & 77 & 11.85 & 884.30 & 97.70 & 77.29 & 77.88 & 50.29 & 1.86 & 90.31 \\
\hline \multicolumn{10}{|c|}{ Summary statistics for active continuous streamgages in the West hydrologic region } \\
\hline \multicolumn{10}{|c|}{29 continuous streamgages summarized } \\
\hline 10th percentile ${ }^{1}$ & 19 & 4.63 & 50.00 & 27.63 & 3.88 & 24.93 & 19.44 & 1.59 & 47.99 \\
\hline Median & 44 & 6.57 & 419.00 & 80.00 & 41.50 & 42.84 & 29.56 & 1.72 & 72.36 \\
\hline \multicolumn{10}{|c|}{ Summary statistics for active continuous streamgages in the Northwest hydrologic region } \\
\hline \multicolumn{10}{|c|}{8 continuous streamgages summarized } \\
\hline 10th percentile ${ }^{1}$ & 33 & 2.94 & 51.92 & 49.42 & 21.74 & 32.02 & 31.74 & 1.60 & 26.88 \\
\hline Median & 64 & 4.63 & 206.00 & 78.34 & 49.41 & 59.09 & 41.57 & 1.73 & 69.44 \\
\hline 90th percentile ${ }^{1}$ & 98 & 14.43 & $1,278.10$ & 98.21 & 69.80 & 73.58 & 59.89 & 1.82 & 78.45 \\
\hline \multicolumn{10}{|c|}{ Summary statistics for continuous streamgages in the Northwest Foothills hydrologic region } \\
\hline \multicolumn{10}{|c|}{11 continuous streamgages summarized } \\
\hline 10th percentile ${ }^{1}$ & 11 & 9.91 & 66.10 & 0.00 & 0.00 & 0.03 & 12.40 & 1.14 & 0.00 \\
\hline Median & 26 & 14.82 & 322.00 & 18.03 & 2.97 & 3.26 & 18.52 & 1.40 & 9.36 \\
\hline 90th percentile ${ }^{1}$ & 80 & 30.12 & $1,032.00$ & 29.65 & 15.46 & 16.39 & 23.15 & 1.52 & 20.00 \\
\hline
\end{tabular}


Table 10. Statistical summaries of selected streamgage characteristics and drainage-basin characteristics for continuous streamgages included in the Montana regional regression analyses (Sando, R., and others, 2018).-Continued

[PFVI, peak-flow variability index calculated by 100 times the standard deviation of the peak flows (base-10 logarithms) divided by the mean of the peak flows (base-10 logarithms); the standard deviations and means of the peak flows were calculated using Bulletin 17B procedures (U.S. Interagency Advisory Council on Water Data, 1982) for fitting the log-Pearson III distribution. CONTDA, contributing drainage area, in square miles; $E L_{5000}$, percentage of basin above 5,000 feet elevation; $E L_{6000}$, percentage of basin above 6,000 feet elevation; $S L O P 30 \_30 \mathrm{M}$, percentage of basin with slopes greater than or equal to 30 percent; PRECIP, mean annual precipitation, in inches; ET0306MOD, spring mean monthly evapotranspiration, in inches per month; FOREST, percentage of basin in forest]

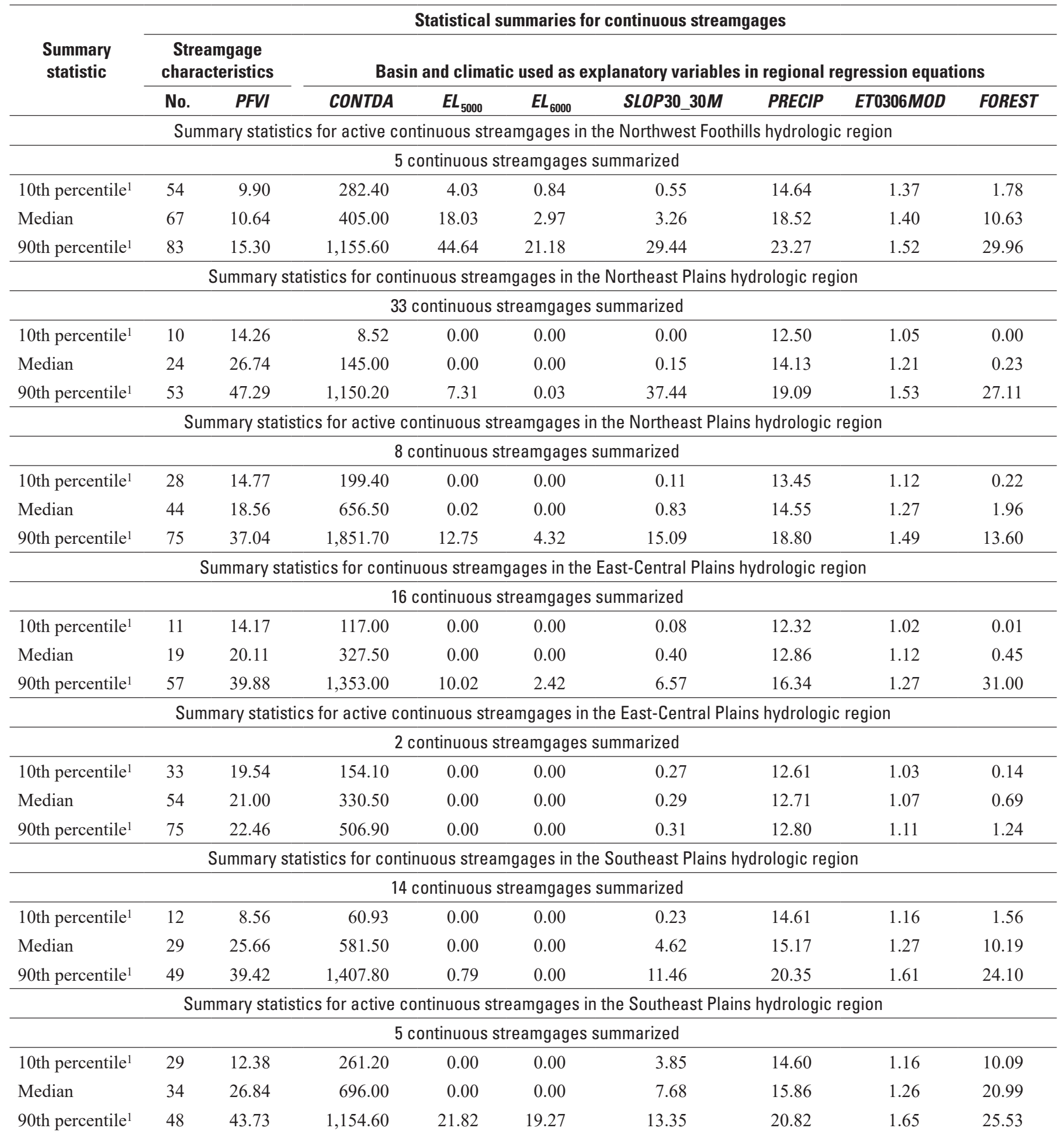


Table 10. Statistical summaries of selected streamgage characteristics and drainage-basin characteristics for continuous streamgages included in the Montana regional regression analyses (Sando, R., and others, 2018).- - Continued

[PFVI, peak-flow variability index calculated by 100 times the standard deviation of the peak flows (base-10 logarithms) divided by the mean of the peak flows (base-10 logarithms); the standard deviations and means of the peak flows were calculated using Bulletin 17B procedures (U.S. Interagency Advisory Council on Water Data, 1982) for fitting the log-Pearson III distribution. CONTDA, contributing drainage area, in square miles; $E L_{5000}$, percentage of basin above 5,000 feet elevation; $E L_{6000}$, percentage of basin above 6,000 feet elevation; SLOP30_30M, percentage of basin with slopes greater than or equal to 30 percent; PRECIP, mean annual precipitation, in inches; ET0306MOD, spring mean monthly evapotranspiration, in inches per month; FOREST, percentage of basin in forest]

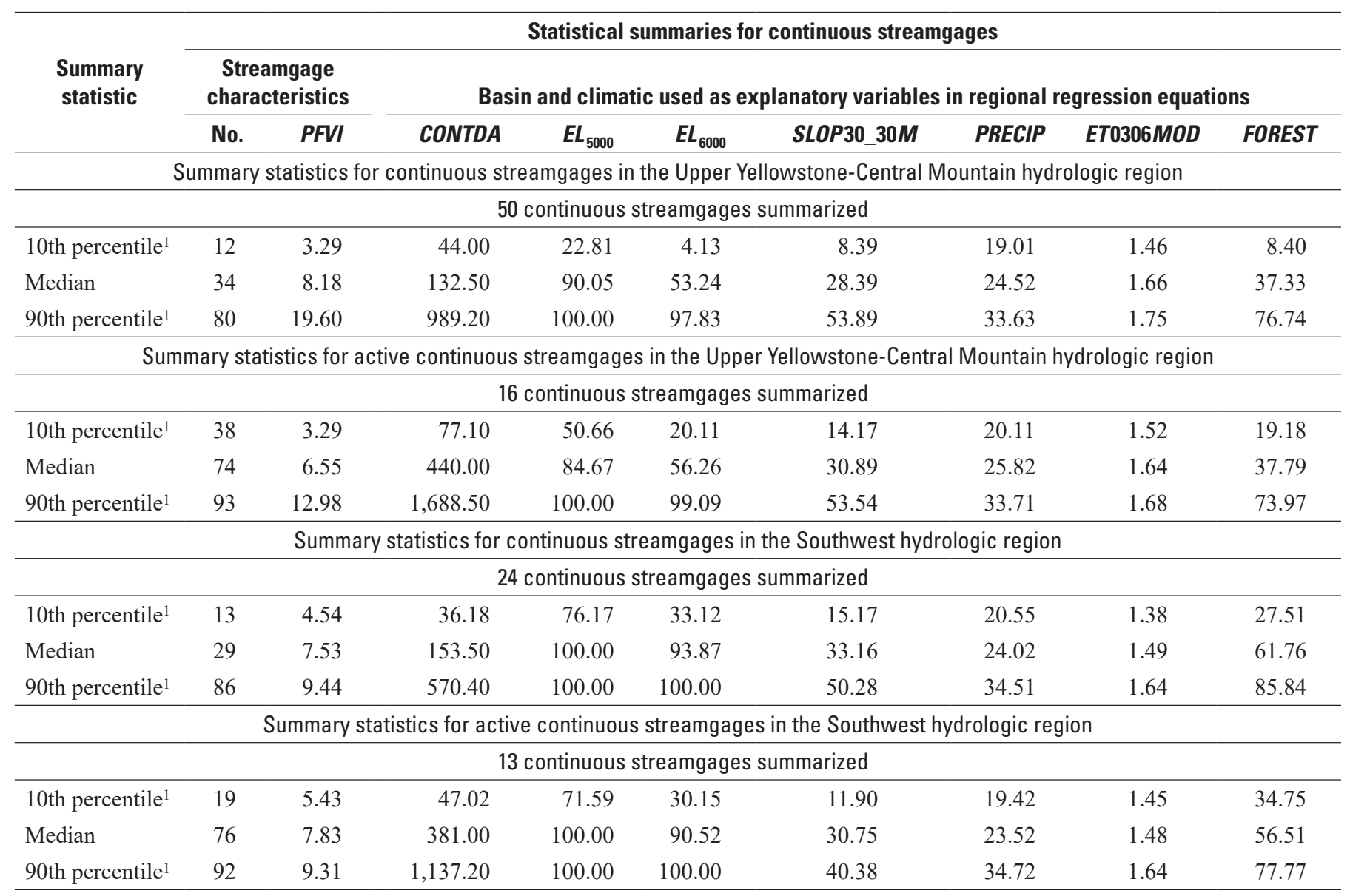

${ }^{1}$ Nonexceedance percentile.

Northwest hydrologic region relative to the other hydrologic regions makes it more difficult to discern clear patterns in the various relations.

For 44 unregulated streamgages in the Northwest hydrologic region, $P F V I$ generally monotonically decreases with increasing drainage area (fig. 9A). Variability about the LOWESS line is larger for drainage areas less than about $10 \mathrm{mi}^{2}$, but there are few streamgages in that range. Intuitively, highly variable small-scale hydroclimatic processes are integrated with increasing drainage area such that variability in many hydrologic characteristics is reduced. $P F V I$ also generally decreases with increasing elevation (fig. 9B), precipitation (fig. $9 C$ ), and years of record (fig. 9D). For the relations between $P F V I$ and drainage area (fig. $9 A$ ), elevation (fig. $9 B$ ), and years of record (fig. 9D), the LOWESS lines for the Northwest hydrologic region generally are below or near the LOWESS lines for all unregulated streamgages in Montana.
Relations between contributing drainage area and mean basin elevation, mean annual precipitation, and years of peakflow records for the unregulated streamgages are presented in figure 10. Streamgages with greater than about 40 years of record are predominantly located on streams with contributing drainage areas greater than about $100 \mathrm{mi}^{2}$ (fig. 10C), which might contribute to the $P F V I$ and years of record relations (fig. 9D).

The median PFVI value for streamgages in the Northwest hydrologic region $(6.04$, table 3$)$ is substantially less than the median for all unregulated streamgages in Montana (18.26, table 3) and ranks as the eighth largest median PFVI among the eight hydrologic regions. A major factor contributing to low peak-flow variability in the Northwest hydrologic region might be the strong dominance of snowmelt runoff in the annual hydrograph of the streamgages. For unregulated streamgages in the Northwest hydrologic region, fall and winter 
Table 11. Statistical summaries of selected streamgage characteristics and drainage-basin characteristics for crest-stage gages included in the Montana regional regression analyses (Sando, R., and others, 2018).

[PFVI, peak-flow variability index calculated by 100 times the standard deviation of the peak flows (base-10 logarithms) divided by the mean of the peak flows (base-10 logarithms); the standard deviations and means of the peak flows were calculated using Bulletin 17B procedures (U.S. Interagency Advisory Council on Water Data, 1982) for fitting the log-Pearson III distribution. CONTDA, contributing drainage area, in square miles; $E L_{5000}$, percentage of basin above 5,000 feet elevation; $E L_{6000}$, percentage of basin above 6,000 feet elevation; $S L O P 30 \_30 \mathrm{M}$, percentage of basin with slopes greater than or equal to 30 percent; $P R E C I P$, mean annual precipitation, in inches; ET0306MOD, spring mean monthly evapotranspiration, in inches per month; FOREST, percentage of basin in forest]

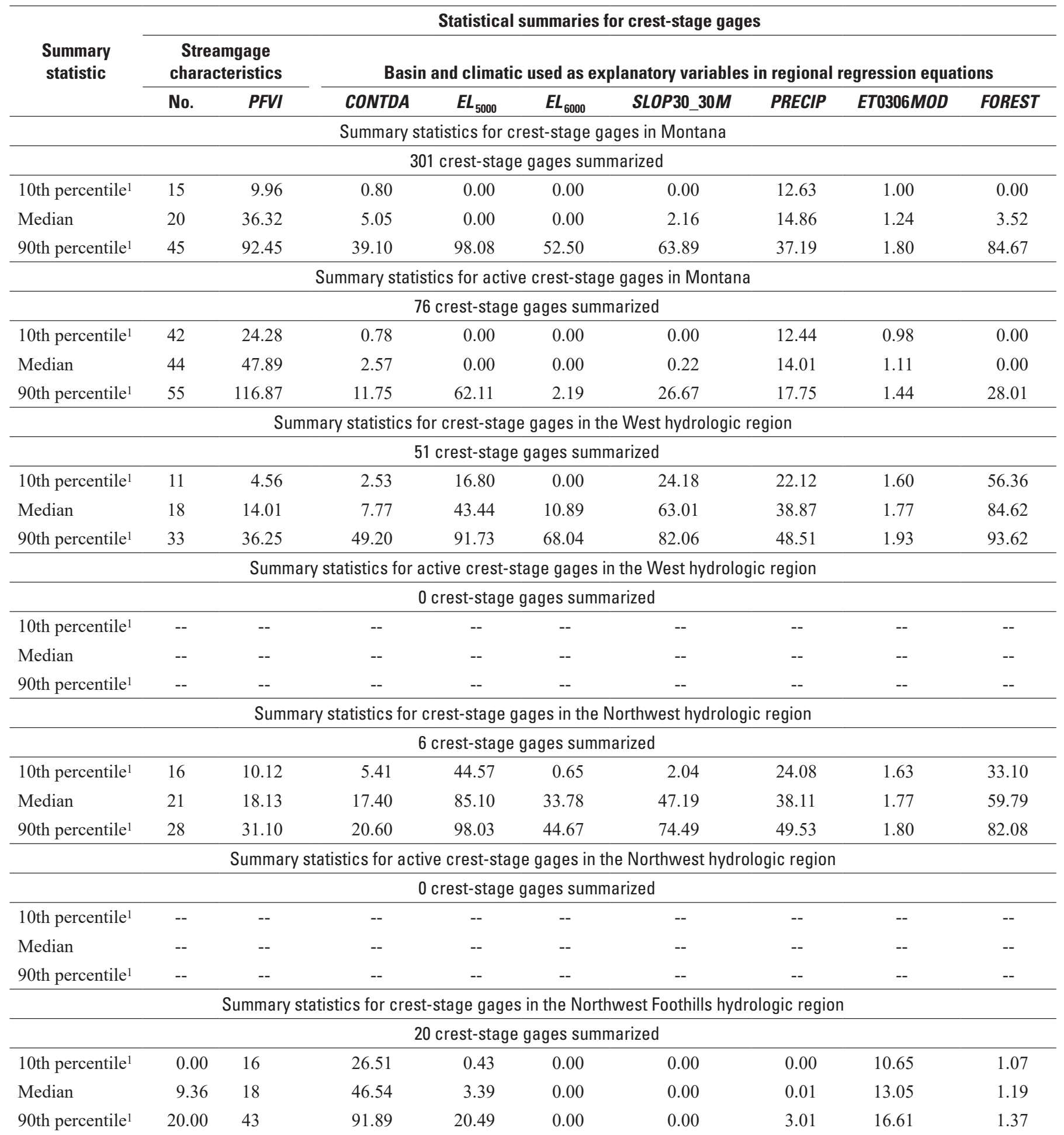


Table 11. Statistical summaries of selected streamgage characteristics and drainage-basin characteristics for crest-stage gages included in the Montana regional regression analyses (Sando, R., and others, 2018).-Continued

[PFVI, peak-flow variability index calculated by 100 times the standard deviation of the peak flows (base-10 logarithms) divided by the mean of the peak flows (base-10 logarithms); the standard deviations and means of the peak flows were calculated using Bulletin 17B procedures (U.S. Interagency Advisory Council on Water Data, 1982) for fitting the log-Pearson III distribution. CONTDA, contributing drainage area, in square miles; $E L_{5000}$, percentage of basin above 5,000 feet elevation; $E L_{6000}$, percentage of basin above 6,000 feet elevation; SLOP30_30M, percentage of basin with slopes greater than or equal to 30 percent; $P R E C I P$, mean annual precipitation, in inches; ET0306MOD, spring mean monthly evapotranspiration, in inches per month; FOREST, percentage of basin in forest]

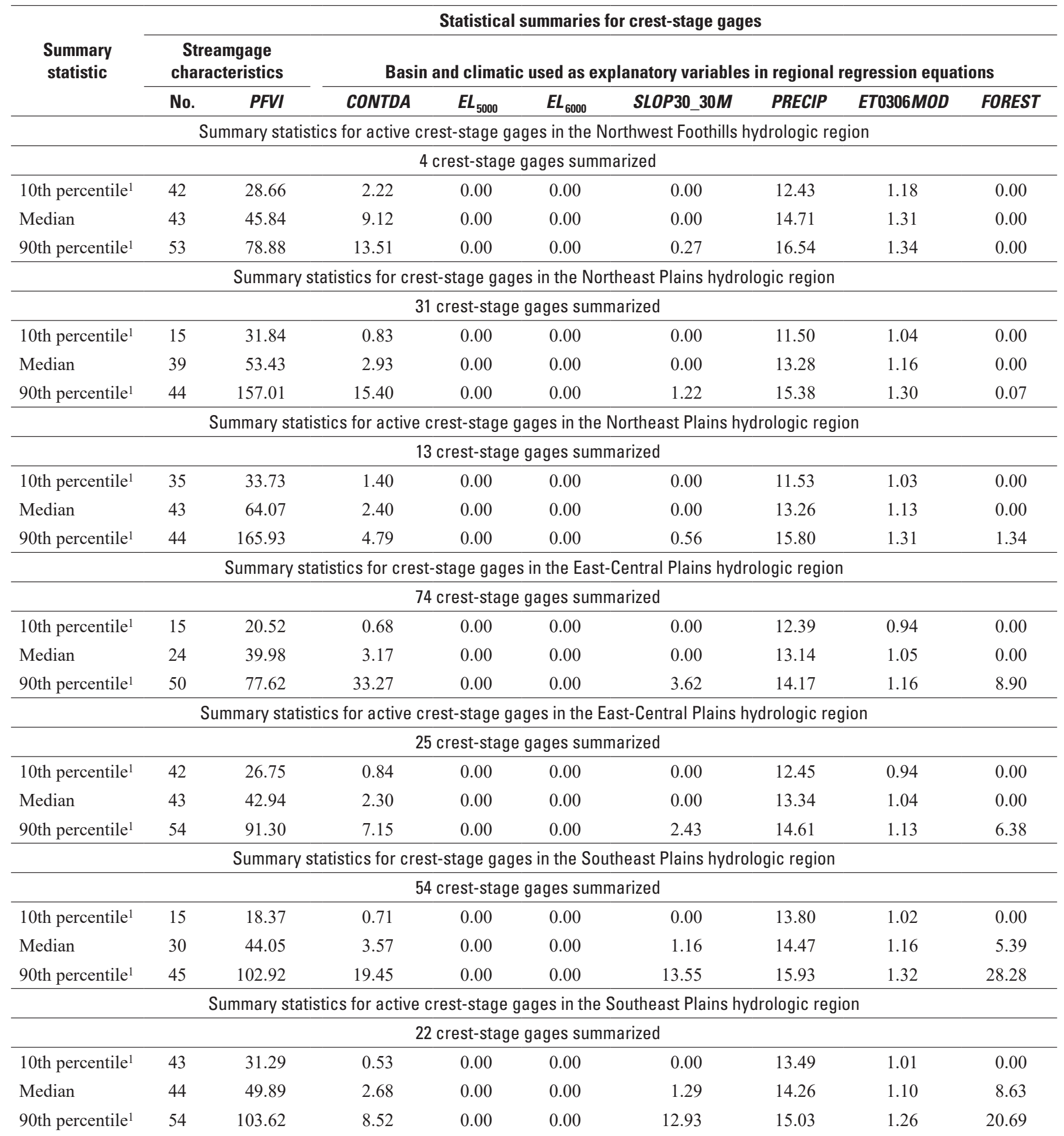


Table 11. Statistical summaries of selected streamgage characteristics and drainage-basin characteristics for crest-stage gages included in the Montana regional regression analyses (Sando, R., and others, 2018).- - Continued

[PFVI, peak-flow variability index calculated by 100 times the standard deviation of the peak flows (base-10 logarithms) divided by the mean of the peak flows (base-10 logarithms); the standard deviations and means of the peak flows were calculated using Bulletin 17B procedures (U.S. Interagency Advisory Council on Water Data, 1982) for fitting the log-Pearson III distribution. CONTDA, contributing drainage area, in square miles; $E L_{5000}$, percentage of basin above 5,000 feet elevation; $E L_{6000}$, percentage of basin above 6,000 feet elevation; $S L O P 30 \_30 \mathrm{M}$, percentage of basin with slopes greater than or equal to 30 percent; PRECIP, mean annual precipitation, in inches; ET0306MOD, spring mean monthly evapotranspiration, in inches per month; FOREST, percentage of basin in forest]

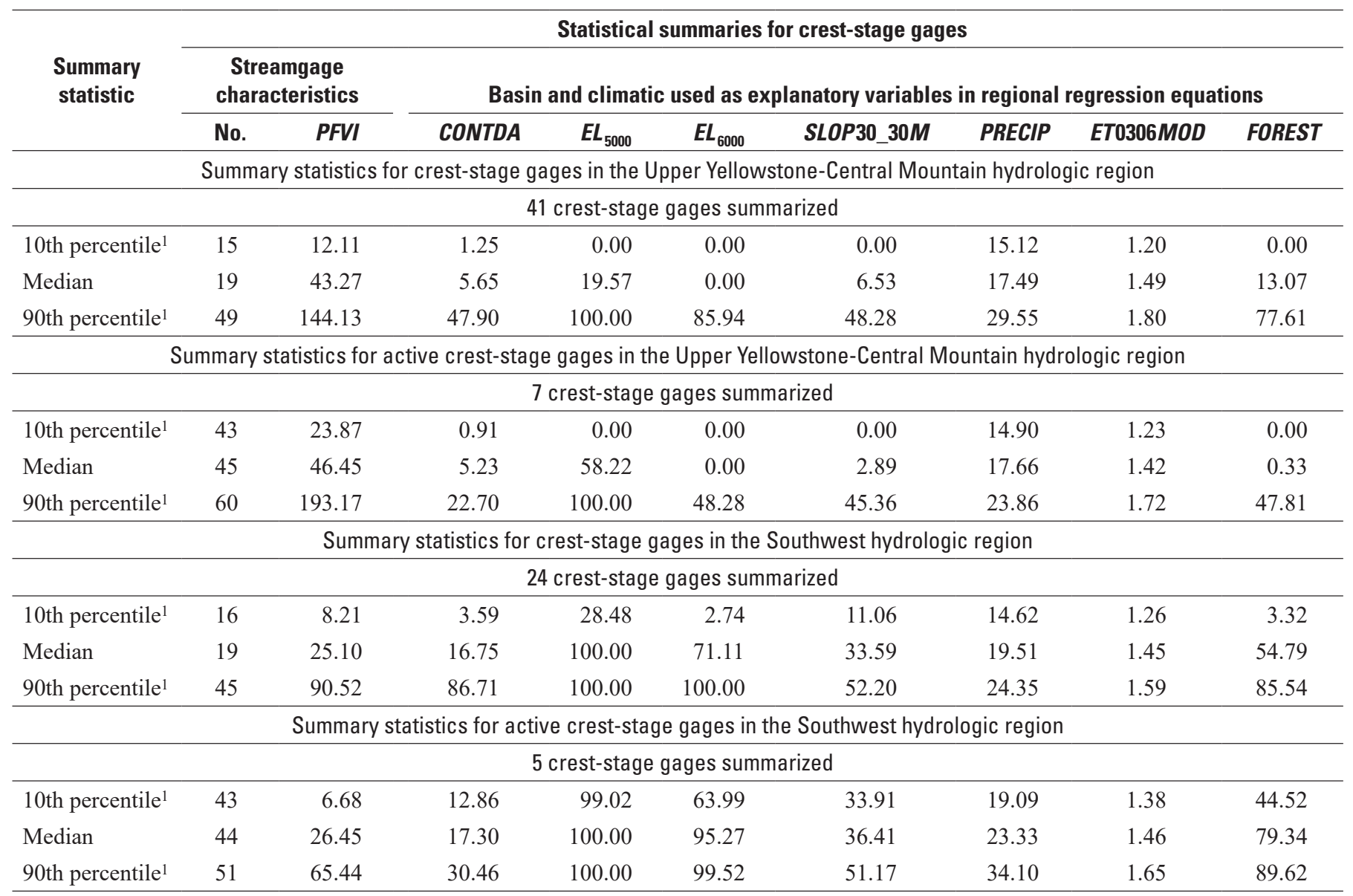

${ }^{1}$ Nonexceedance percentile. 

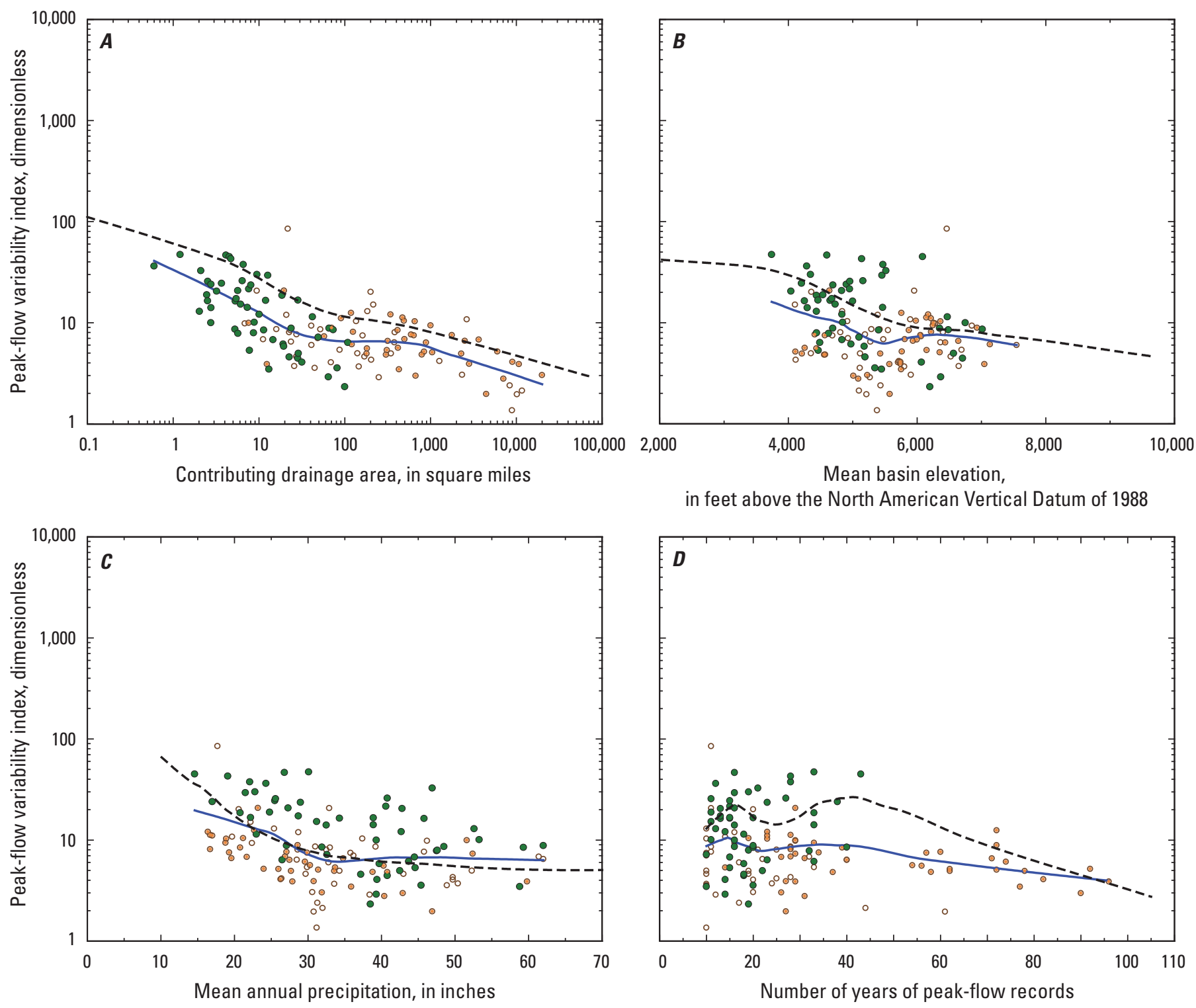

in feet above the North American Vertical Datum of 1988

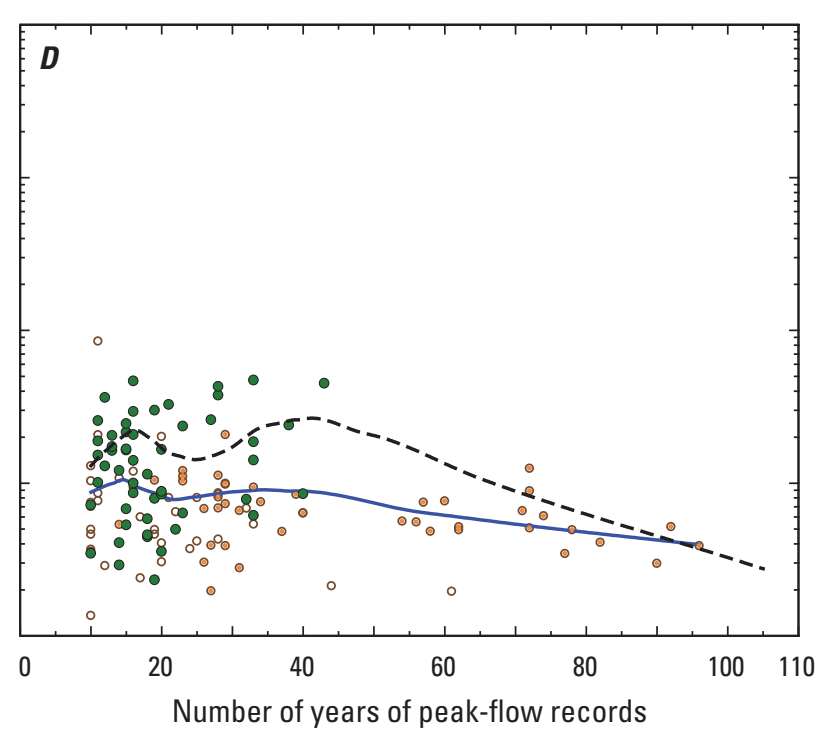

\section{EXPLANATION}

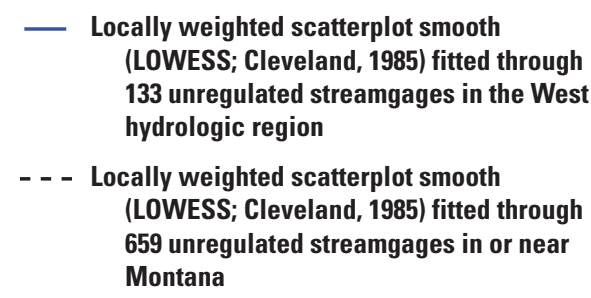

- Crest-stage streamgage

- Continuous streamgage

- Interior dot denotes active streamgage in water year 2017

Figure 6. Relations between peak-flow variability index and contributing drainage area, mean basin elevation, mean annual precipitation, and years of peak-flow records for 133 unregulated streamgages in the West hydrologic region. $A$, Peak-flow variability and contributing drainage area relations. $B$, Peak-flow variability and mean basin elevation relations. $C$, Peak-flow variability and mean annual precipitation relations. $D$, Peak-flow variability and years of peak-flow records relations. 


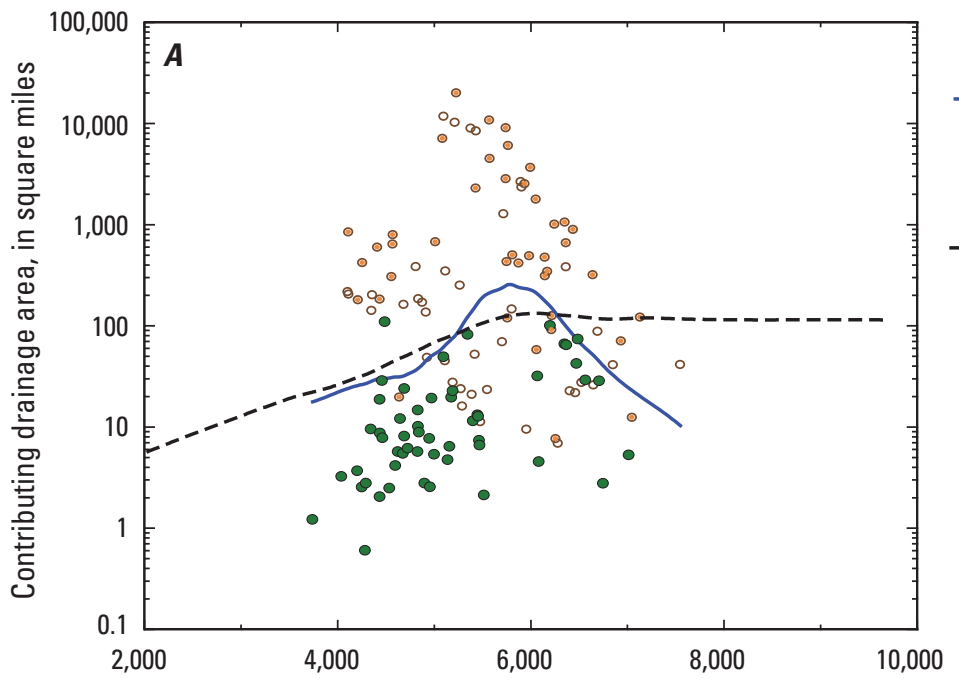

\section{EXPLANATION}

Locally weighted scatterplot smooth (LOWESS; Cleveland, 1985) fitted through 133 unregulated streamgages in the West hydrologic region

- - - Locally weighted scatterplot smooth (LOWESS; Cleveland, 1985) fitted through 659 unregulated streamgages in or near Montana

- Crest-stage streamgage

- Continuous streamgage

Interior dot denotes active streamgage in water year 2017

Mean basin elevation, in feet above the North American Vertical Datum of 1988
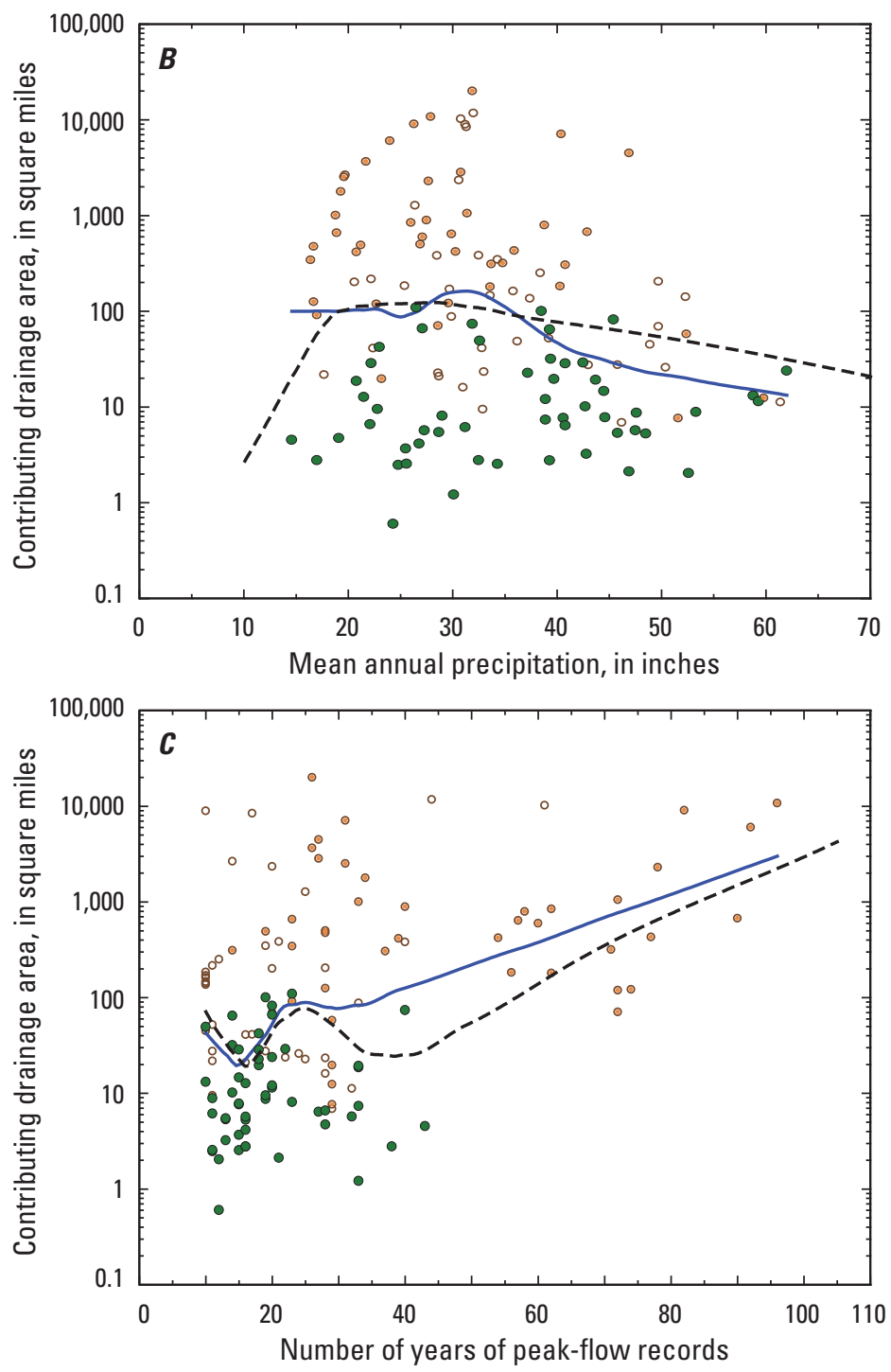

Figure 7. Relations between contributing drainage area and mean basin elevation, mean annual precipitation, and years of peak-flow records for 133 unregulated streamgages in the West hydrologic region. $A$, Contributing drainage area and mean basin elevation relations. $B$, Contributing drainage area and mean annual precipitation relations. $C$, Contributing drainage area and years of peak-flow records relations. 


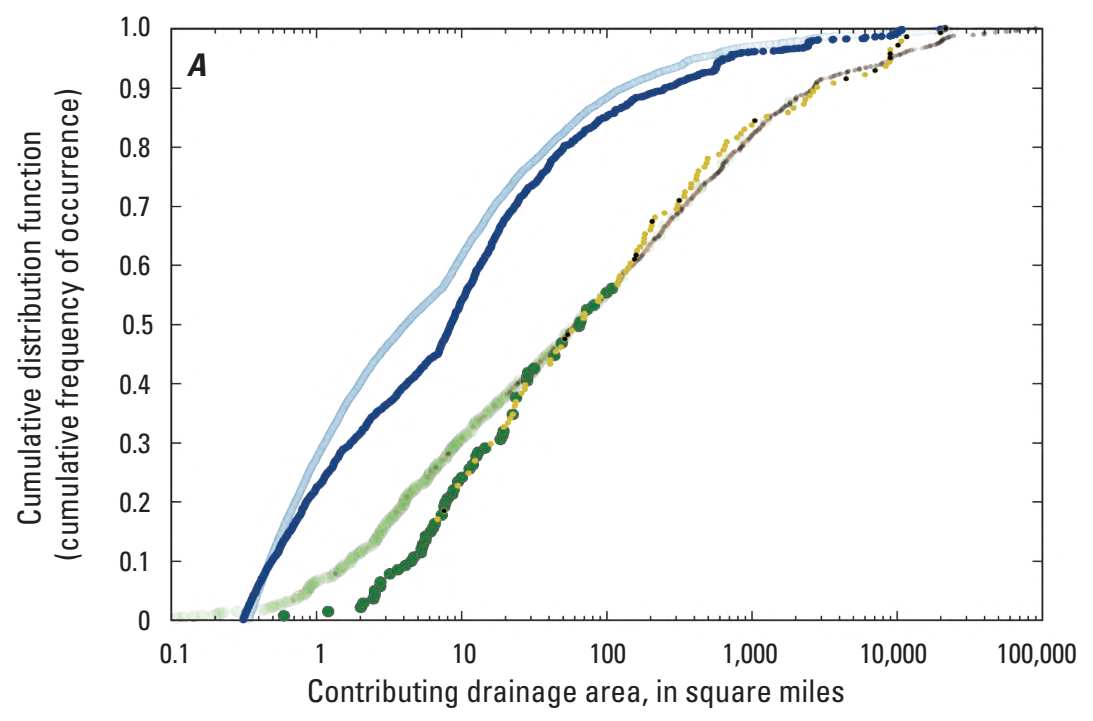

\section{EXPLANATION}

- Road and stream intersection in the West hydrologic region

One of 12,639 road and stream intersections in Montana, as shown in figure 5-0pen symbols appear as solid symbols because of the high data density

Regulated and unregulated streamgages in the West hydrologic region

- Crest-stage streamgage

- Unregulated continuous streamgage

- Regulated continuous streamgage

Regulated and unregulated streamgages in or near Montana, as shown in figure 5

Crest-stage streamgage in or near Montana Unregulated streamgages in or near Montana

Regulated streamgages in or near Montana

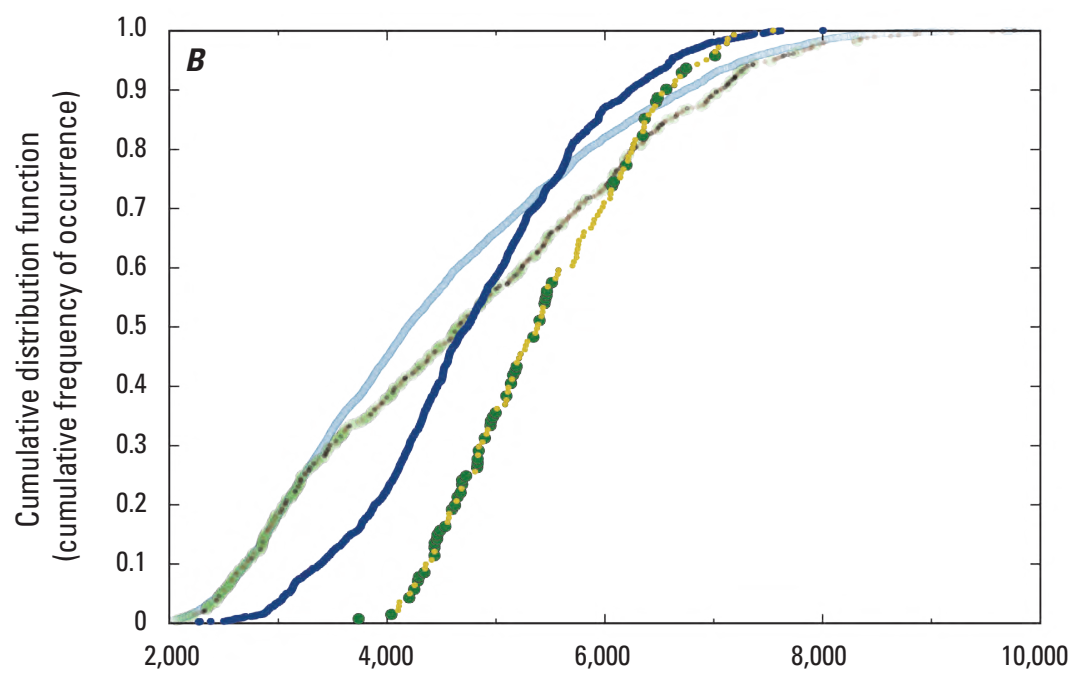

Mean basin elevation, in feet above the North American Vertical Datum of 1988

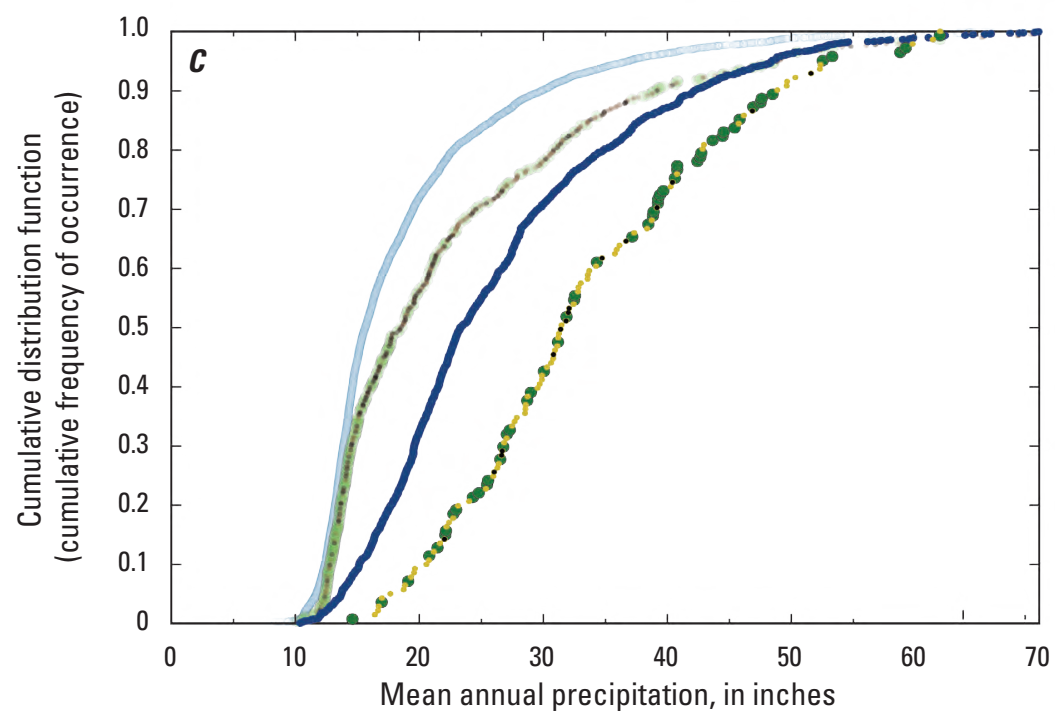

Figure 8. Cumulative distribution functions of selected drainage-basin characteristics for 2,380 road and stream intersections and for 141 streamgages (regulated and unregulated) in the West hydrologic region. $A$, Contributing drainage area relations. $B$, Mean basin elevation relations. $C$, Mean annual precipitation relations. 
(October-February) precipitation accounts for about 38 percent of annual precipitation (table 8), which can result in large accumulated snowpacks (Sando and McCarthy, 2018) that contribute to streamflows during the typical snowmelt runoff period of May through mid-July. May-June precipitation accounts for about 25.4 percent of annual precipitation (table 8), which ranks seventh among the hydrologic regions, and July-August precipitation accounts for 13.1 percent of annual precipitation, which ranks eighth among the eight hydrologic regions. In the Northwest hydrologic region, annual peak flows predominantly are in May and June (fig. 2 of Sando, R., and others, 2018). Dominance of snowmelt in the annual hydrograph tends to provide temporal integration of a substantial part of the annual precipitation inputs and contributes to the low PFVIs for streamgages in the Northwest hydrologic region.

Although streamgages in the Northwest hydrologic region have less than typical $P F V I$ s, about 56 percent of the streamgages are considered to have mixed-population characteristics (table 1) that result in a small number of unusually large peak flows that are substantially larger than the main body of peak flows. Typically, the unusually large peak-flow events result from extremely intense rainfall events in May and June that happen near the peak of snowmelt runoff. Mixedpopulation peak-flow datasets often are in streamgages with drainage basins along or near the Continental Divide, which closely corresponds to the general location of the Northwest hydrologic region. In some areas of the Northwest hydrologic region, some mixed-population peak-flow datasets result from unusual rapid snowmelt events during winter, sometimes in association with rainfall. The large peak-flow variability of mixed-population peak-flow datasets might not be well represented in the PFVI values because the unusually large peakflow events are infrequent and might not substantially affect the calculation of the PFVI values. Partly because of the large proportion of mixed-population streamgages in the Northwest hydrologic region, those streamgages do not have disproportionally strong positive residuals for the 1-percent AEP regression or significant influence. Among the candidate explanatory variables included in the regional regression analyses, there are no variables that represent spatial variability in precipitation intensity (such as indices of the 100-year 24-hour precipitation; for example, U.S. Weather Bureau, 1961). Inclusion of variables that represent spatial variability in precipitation intensity might help address some mixed-population issues and improve potential future regional regression analyses in the Northwest hydrologic region.

The CDFs of selected basin characteristics (drainage area, mean basin elevation, and mean annual precipitation) for the road and stream intersections and for the streamgages in the Northwest hydrologic region are shown in figure 11. With respect to drainage area, the CDF of road and stream intersections for the Northwest hydrologic region is similar to the CDF of road and stream intersections for all of Montana (fig. 11A), but with greater representation of drainage areas greater than about $100 \mathrm{mi}^{2}$. In the Northwest hydrologic region, the $\mathrm{CDF}$ of streamgages diverges from the $\mathrm{CDF}$ of road and stream intersections in the range of drainage areas less than about $60 \mathrm{mi}^{2}$, indicating underrepresentation in that range.

The Northwest hydrologic region generally is higher in elevation than Montana as a whole. Mean basin elevation for road and stream intersections in the Northwest hydrologic region ranges from 3,355 to 7,458 $\mathrm{ft}$ (Dutton and others, 2021) with a median of 5,493 $\mathrm{ft}$ (table 4). The range for the Northwest hydrologic region is smaller than for all of Montana (1,951-9,974 ft; Dutton and others, 2021) and the median for the Northwest hydrologic region is higher than for all of Montana (4,173 ft; table 4). There are substantial differences between the CDFs of road and stream intersections for the Northwest hydrologic region relative to the CDFs of road and stream intersections for all of Montana (fig. 11B). With respect to mean basin elevation, the pattern of the streamgage CDFs reasonably represents the road and stream intersection $\mathrm{CDF}$ but with some underrepresentation at elevations less than about 5,400 ft.

The Northwest hydrologic region generally is wetter than Montana as a whole. Mean annual precipitation for road and stream intersections in the Northwest hydrologic region ranges from 13.2 to 91.3 inches (Dutton and others, 2021) with a median of 31.5 inches (table 5). The range for the Northwest hydrologic region is smaller than for all of Montana (8.4-91.3 inches; Dutton and others, 2021) and the median for the Northwest hydrologic region is larger than for all of Montana (15.7 inches; table 5). There are substantial differences between the CDFs of road and stream intersections for the Northwest hydrologic region relative to the CDFs of road and stream intersections for all of Montana (fig. 11C). With respect to mean annual precipitation, the pattern of the streamgage CDFs reasonably represents the road and stream intersection CDF but with some underrepresentation of mean annual precipitation less than about 37 inches.

The explanatory variable for the Northwest hydrologic region RREs is CONTDA (table 6). The 1-percent AEP RRE for the West hydrologic region has an SEP of 13.6 percent, which is substantially less than the area-weighted mean SEP for all hydrologic regions in Montana (63.3 percent; table 6). The RREs for the Northwest hydrologic region were developed using weighted least squares regression to better handle complexities introduced by the large proportion of mixedpopulation peak-flow datasets (Sando, R., and others, 2018); the use of weighted least squares regression might contribute to the low SEP. For the 1-percent AEP regression for the Northwest hydrologic region, 12.5 percent of the streamgages have significant leverage and 6.3 percent of the streamgages have significant influence (table 7). The significant leverage percentage is somewhat larger the significant leverage percentage for all of the streamgages in Montana used in the regional regression analyses (8.2 percent; table 7 ) and the significant influence percentage is somewhat smaller than the significant influence percentage for all of the streamgages in Montana used in the regional regression analyses (10.4 percent; table 7). 
Table 12. Information on streamgages in the West hydrologic region with significant leverage and influence in the Montana regional regression analyses (Sando, R., and others, 2018).

[ID, identification; NAD 83, North American Datum of 1983; $n$, total number of years of peak-flow records; CONTDA, contributing drainage area, in square miles; PRECIP, mean annual precipitation, in inches; FOREST, percentage of basin in forest; AEP, annual exceedance probability; CSG, crest-stage gage; CONT, continuous streamgage]

\begin{tabular}{|c|c|c|c|c|c|c|c|}
\hline $\begin{array}{c}\text { Map } \\
\text { number } \\
\text { (fig. 1) }\end{array}$ & $\begin{array}{l}\text { Station ID } \\
\text { number }\end{array}$ & Station name & $\begin{array}{l}\text { Latitude, } \\
\text { in decimal } \\
\text { degrees } \\
\text { (NAD 83) }\end{array}$ & $\begin{array}{c}\text { Longitude, } \\
\text { in decimal } \\
\text { degrees } \\
\text { (NAD 83) }\end{array}$ & $\begin{array}{c}\text { Type of } \\
\text { streamgage }\end{array}$ & $\begin{array}{c}\text { Status of } \\
\text { streamgage } \\
\text { in water year } \\
2017\end{array}$ & $n$ \\
\hline \multicolumn{8}{|c|}{ Streamgages with significant leverage } \\
\hline 598 & 12301700 & Kootenai River tributary near Rexford, Montana & 48.7985 & -115.2964 & CSG & Discontinued & 12 \\
\hline 626 & ${ }^{2} 12323300$ & Smith Gulch near Silver Bow, Montana & 45.9570 & -12.6637 & $\mathrm{CSG}$ & Discontinued & 43 \\
\hline 629 & 212323750 & Silver Bow Creek at Warm Springs, Montana & 46.1795 & -112.7806 & CONT & Active & 33 \\
\hline 634 & 212324200 & Clark Fork at Deer Lodge, Montana & 46.3977 & -112.7425 & CONT & Active & 38 \\
\hline 638 & ${ }^{2} 12324700$ & Clark Fork tributary near Drummond, Montana & 46.6196 & -113.0339 & CSG & Discontinued & 38 \\
\hline 645 & ${ }^{2} 12331700$ & Edwards Gulch at Drummond, Montana & 46.6701 & -113.1456 & CSG & Discontinued & 28 \\
\hline 646 & 12331800 & Clark Fork near Drummond, Montana & 46.7119 & -113.3308 & CONT & Active & 24 \\
\hline 676 & 12347500 & Blodgett Creek near Corvallis, Montana & 46.2694 & -114.2371 & CONT & Discontinued & 24 \\
\hline 738 & 12377150 & $\begin{array}{l}\text { Mission Creek above reservoir, near St. Ignatius, } \\
\text { Montana }\end{array}$ & 47.3228 & -113.9794 & CONT & Active & 34 \\
\hline \multicolumn{8}{|c|}{ Streamgages with significant influence } \\
\hline 608 & 12302400 & Shaughnessy Creek near Libby, Montana & 48.3031 & -115.5948 & $\mathrm{CSG}$ & Discontinued & 33 \\
\hline 612 & 12303400 & Ross Creek near Troy, Montana & 48.2071 & -115.8709 & CSG & Discontinued & 20 \\
\hline 624 & 12323240 & Blacktail Creek at Butte, Montana & 45.9947 & -112.5357 & CONT & Active & 28 \\
\hline 626 & 212323300 & Smith Gulch near Silver Bow, Montana & 45.9570 & -112.6637 & CSG & Discontinued & 43 \\
\hline 629 & 212323750 & Silver Bow Creek at Warm Springs, Montana & 46.1795 & -112.7806 & CONT & Active & 33 \\
\hline 634 & 212324200 & Clark Fork at Deer Lodge, Montana & 46.3977 & -112.7425 & CONT & Active & 38 \\
\hline 638 & ${ }^{2} 12324700$ & Clark Fork tributary near Drummond, Montana & 46.6196 & -113.0339 & CSG & Discontinued & 38 \\
\hline 639 & 12324800 & Morris Creek near Drummond, Montana & 46.6655 & -113.0999 & CSG & Discontinued & 16 \\
\hline 645 & ${ }^{2} 12331700$ & Edwards Gulch at Drummond, Montana & 46.6701 & -113.1456 & CSG & Discontinued & 28 \\
\hline 672 & 12344300 & Burke Gulch near Darby, Montana & 46.0242 & -114.1511 & CSG & Discontinued & 28 \\
\hline 679 & 12350200 & Gash Creek near Victor, Montana & 46.4055 & -114.2566 & CSG & Discontinued & 16 \\
\hline 717 & 12363900 & Rock Creek near Olney, Montana & 48.6122 & -114.6519 & CSG & Discontinued & 15 \\
\hline 724 & 12367500 & Ashley Creek near Kalispell, Montana & 48.1650 & -114.4324 & CONT & Discontinued & 20 \\
\hline 741 & 12383500 & Big Knife Creek near Arlee, Montana & 47.1473 & -113.9745 & CONT & Discontinued & 29 \\
\hline
\end{tabular}

${ }^{1}$ The nonexceedance percentile for the basin or climatic variable value was calculated in relation to the values for all streamgages included in the regional regression analyses for the indicated hydrologic region.

${ }^{2}$ Streamgages having both significant leverage and significant influence. 


\begin{tabular}{|c|c|c|c|c|c|c|c|c|}
\hline \multirow{2}{*}{ CONTDA } & \multirow{2}{*}{$\begin{array}{c}\text { Nonexceedance } \\
\text { percentile }^{1} \\
\text { for CONTDA }\end{array}$} & \multirow{2}{*}{ PRECIP } & \multirow{2}{*}{$\begin{array}{l}\text { Nonexceedance } \\
\text { percentile }{ }^{1} \\
\text { for } P R E C I P\end{array}$} & \multirow{2}{*}{ FOREST } & \multirow{2}{*}{$\begin{array}{c}\text { Nonexceedance } \\
\text { percentile }{ }^{1} \\
\text { for FOREST }\end{array}$} & \multicolumn{3}{|c|}{$\begin{array}{l}\text { Regression residuals for the } \\
\text { specified AEP regression analyses }\end{array}$} \\
\hline & & & & & & $\begin{array}{l}\text { 10-percent } \\
\text { AEP }\end{array}$ & $\begin{array}{l}\text { 4-percent } \\
\text { AEP }\end{array}$ & $\begin{array}{l}\text { 1-percent } \\
\text { AEP }\end{array}$ \\
\hline \multicolumn{9}{|c|}{ Streamgages with significant leverage } \\
\hline 0.60 & 0.9 & 24.3 & 17.7 & 46.2 & 6.2 & 0.049 & -0.011 & -0.086 \\
\hline 4.52 & 12.4 & 14.6 & 0.9 & 29.8 & 1.8 & 0.245 & 0.301 & 0.379 \\
\hline 473 & 87.6 & 16.7 & 1.8 & 45.1 & 5.3 & -0.310 & -0.327 & -0.347 \\
\hline 1,001 & 95.6 & 18.8 & 4.4 & 44.1 & 4.4 & -0.381 & -0.386 & -0.391 \\
\hline 2.77 & 8.0 & 17.0 & 2.7 & 20.4 & 0.9 & 0.469 & 0.458 & 0.451 \\
\hline 4.71 & 13.3 & 19.1 & 5.3 & 32.5 & 2.7 & 0.169 & 0.247 & 0.348 \\
\hline 2,516 & 100.0 & 19.6 & 6.2 & 47.7 & 7.1 & -0.126 & -0.090 & -0.020 \\
\hline 25.9 & 46.9 & 50.4 & 90.3 & 49.3 & 8.8 & -0.073 & -0.100 & -0.127 \\
\hline 12.4 & 33.6 & 59.8 & 97.3 & 48.1 & 8.0 & -0.117 & -0.148 & -0.183 \\
\hline \multicolumn{9}{|c|}{ Streamgages with significant influence } \\
\hline 1.21 & 1.8 & 30.1 & 39.8 & 89.2 & 80.5 & 0.448 & 0.563 & 0.732 \\
\hline 23.8 & 46.0 & 62.0 & 99.1 & 86.0 & 72.6 & 0.407 & 0.499 & 0.628 \\
\hline 90.9 & 65.5 & 17.0 & 3.5 & 57.4 & 13.3 & -0.230 & -0.288 & -0.361 \\
\hline 4.52 & 12.4 & 14.6 & 0.9 & 29.8 & 1.8 & 0.245 & 0.301 & 0.379 \\
\hline 473 & 87.6 & 16.7 & 1.8 & 45.1 & 5.3 & -0.310 & -0.327 & -0.347 \\
\hline 1,001 & 95.6 & 18.8 & 4.4 & 44.1 & 4.4 & -0.381 & -0.386 & -0.391 \\
\hline 2.77 & 8.0 & 17.0 & 2.7 & 20.4 & 0.9 & 0.469 & 0.458 & 0.451 \\
\hline 12.7 & 34.5 & 21.5 & 10.6 & 43.9 & 3.5 & -0.831 & -0.840 & -0.836 \\
\hline 4.71 & 13.3 & 19.1 & 5.3 & 32.5 & 2.7 & 0.169 & 0.247 & 0.348 \\
\hline 6.58 & 20.4 & 22.1 & 11.5 & 76.3 & 40.7 & -0.347 & -0.347 & -0.325 \\
\hline 2.76 & 7.1 & 39.3 & 66.4 & 79.3 & 49.6 & 0.465 & 0.432 & 0.393 \\
\hline 7.64 & 23.9 & 40.6 & 69.9 & 88.6 & 77.9 & -0.672 & -0.666 & -0.643 \\
\hline 201 & 76.1 & 20.6 & 7.1 & 71.6 & 31.0 & -0.444 & -0.356 & -0.234 \\
\hline 6.86 & 21.2 & 46.2 & 83.2 & 97.0 & 98.2 & -0.359 & -0.372 & -0.386 \\
\hline
\end{tabular}


Table 13. Information on discontinued streamgages in the West hydrologic region that might be candidates for reactivation to improve the streamgage network.

[NAD 83, North American Datum of 1983; $n$, total number of years of peak-flow records; CONTDA, contributing drainage area, in square miles; PRECIP, mean annual precipitation, in inches; FOREST, percentage of basin in forest; CSG, crest-stage gage; CONT, continuous streamgage]

\begin{tabular}{|c|c|c|c|c|c|c|c|c|c|c|c|c|}
\hline $\begin{array}{c}\text { Map } \\
\text { number } \\
\text { (fig. 1) }\end{array}$ & $\begin{array}{c}\text { Station } \\
\text { identification } \\
\text { number }\end{array}$ & Station name & $\begin{array}{l}\text { Latitude, } \\
\text { in decimal } \\
\text { degrees } \\
\text { (NAD 83) }\end{array}$ & $\begin{array}{c}\text { Longitude, } \\
\text { in decimal } \\
\text { degrees } \\
\text { (NAD 83) }\end{array}$ & $\begin{array}{c}\text { Type of } \\
\text { streamgage }\end{array}$ & $n$ & CONTDA & $\begin{array}{l}\text { Nonexceedance } \\
\text { percentile }{ }^{1} \text { for } \\
\text { CONTDA }\end{array}$ & PRECIP & $\begin{array}{c}\text { Nonexceedance } \\
\text { percentile }{ }^{1} \text { for } \\
\text { PRECIP }\end{array}$ & FOREST & $\begin{array}{l}\text { Nonexceedance } \\
\text { percentile }^{1} \text { for } \\
\text { FOREST }\end{array}$ \\
\hline 593 & 12300400 & $\begin{array}{c}\text { Cayuse Creek } \\
\text { near Trego, } \\
\text { Montana }\end{array}$ & 48.6092 & -115.0296 & CSG & 13 & 5.44 & 15.9 & 28.7 & 33.6 & 84.8 & 63.7 \\
\hline 594 & 12300500 & $\begin{array}{c}\text { Fortine Creek } \\
\text { near Trego, } \\
\text { Montana }\end{array}$ & 48.6440 & -114.9112 & $\begin{array}{r}\text { CONT, } \\
\text { CSG }\end{array}$ & 23 & 109 & 66.4 & 26.5 & 23.9 & 75.7 & 39.8 \\
\hline 598 & 12301700 & $\begin{array}{l}\text { Kootenai River } \\
\text { tributary near } \\
\text { Rexford, } \\
\text { Montana }\end{array}$ & 48.7985 & -115.2964 & CSG & 12 & 0.60 & 0.9 & 24.3 & 17.7 & 46.2 & 6.2 \\
\hline 599 & 12301800 & $\begin{array}{l}\text { Gold Creek } \\
\text { near Rexford, } \\
\text { Montana }\end{array}$ & 48.7855 & -115.3170 & CSG & 11 & 6.13 & 18.6 & 31.2 & 43.4 & 84.6 & 61.9 \\
\hline 600 & 12301810 & $\begin{array}{l}\text { Big Creek near } \\
\text { Rexford, } \\
\text { Montana }\end{array}$ & 48.7478 & -115.3537 & CONT & 10 & 136 & 69.0 & 37.4 & 60.2 & 85.7 & 69.0 \\
\hline 603 & 12301993 & $\begin{array}{l}\text { Wolf Creek } \\
\text { tributary } \\
\text { near Libby, } \\
\text { Montana }\end{array}$ & 48.3980 & -114.9189 & CSG & 11 & 2.47 & 4.4 & 24.8 & 18.6 & 93.6 & 92.0 \\
\hline 604 & 12301997 & $\begin{array}{c}\text { Richards Creek } \\
\text { near Libby, } \\
\text { Montana }\end{array}$ & 48.2586 & -115.1999 & CSG & 19 & 9.48 & 29.2 & 22.8 & 15.0 & 56.4 & 11.5 \\
\hline 605 & 12301999 & $\begin{array}{l}\text { Wolf Creek } \\
\text { near Libby, } \\
\text { Montana }\end{array}$ & 48.2336 & -115.2849 & CONT & 11 & 216 & 77.9 & 22.2 & 12.4 & 68.1 & 23.9 \\
\hline 609 & 12302500 & $\begin{array}{c}\text { Granite Creek } \\
\text { near Libby, } \\
\text { Montana }\end{array}$ & 48.3018 & -115.5924 & CONT & 22 & 23.7 & 45.1 & 62.0 & 100.0 & 80.4 & 51.3 \\
\hline 612 & 12303400 & $\begin{array}{c}\text { Ross Creek } \\
\text { near Troy, } \\
\text { Montana }\end{array}$ & 48.2071 & -115.8709 & CSG & 20 & 23.8 & 46.0 & 62.0 & 99.1 & 86.0 & 72.6 \\
\hline
\end{tabular}


Table 13. Information on discontinued streamgages in the West hydrologic region that might be candidates for reactivation to improve the streamgage network.-Continued [NAD 83, North American Datum of 1983; $n$, total number of years of peak-flow records; CONTDA, contributing drainage area, in square miles; PRECIP, mean annual precipitation, in inches; FOREST, percentage of basin in forest; CSG, crest-stage gage; CONT, continuous streamgage]

\begin{tabular}{|c|c|c|c|c|c|c|c|c|c|c|c|c|}
\hline $\begin{array}{c}\text { Map } \\
\text { number } \\
\text { (fig. 1) }\end{array}$ & $\begin{array}{c}\text { Station } \\
\text { identification } \\
\text { number }\end{array}$ & Station name & $\begin{array}{c}\text { Latitude, } \\
\text { in decimal } \\
\text { degrees } \\
\text { (NAD 83) }\end{array}$ & $\begin{array}{c}\text { Longitude, } \\
\text { in decimal } \\
\text { degrees } \\
\text { (NAD 83) }\end{array}$ & $\begin{array}{c}\text { Type of } \\
\text { streamgage }\end{array}$ & $n$ & CONTDA & $\begin{array}{l}\text { Nonexceedance } \\
\text { percentile }^{1} \text { for } \\
\text { CONTDA }\end{array}$ & PRECIP & $\begin{array}{c}\text { Nonexceedance } \\
\text { percentile }^{1} \text { for } \\
\text { PRECIP }\end{array}$ & FOREST & $\begin{array}{l}\text { Nonexceedance } \\
\text { percentile }^{1} \text { for } \\
\text { FOREST }\end{array}$ \\
\hline 613 & 12303440 & $\begin{array}{c}\text { Camp Creek } \\
\text { near Troy, } \\
\text { Montana }\end{array}$ & 48.3210 & -115.8245 & CSG & 20 & 11.4 & 31.9 & 59.3 & 96.5 & 84.7 & 62.8 \\
\hline 615 & 12304040 & $\begin{array}{c}\text { Basin Creek } \\
\text { near Yaak, } \\
\text { Montana }\end{array}$ & 48.9305 & -115.4816 & CONT & 11 & 27.5 & 48.7 & 45.8 & 81.4 & 89.9 & 82.3 \\
\hline 616 & 12304060 & $\begin{array}{c}\text { Blacktail Creek } \\
\text { near Yaak, } \\
\text { Montana }\end{array}$ & 48.9508 & -115.5420 & CSG & 14 & 10.1 & 30.1 & 42.7 & 74.3 & 85.9 & 69.9 \\
\hline 617 & 12304120 & $\begin{array}{c}\text { Zulu Creek } \\
\text { near Yaak, } \\
\text { Montana }\end{array}$ & 48.7302 & -115.6427 & CSG & 13 & 5.33 & 15.0 & 45.8 & 82.3 & 94.7 & 93.8 \\
\hline 618 & 12304250 & $\begin{array}{c}\text { Whitetail Creek } \\
\text { near Yaak, } \\
\text { Montana }\end{array}$ & 48.8287 & -115.8139 & CSG & 15 & 2.53 & 5.3 & 34.3 & 54.9 & 90.9 & 85.8 \\
\hline 620 & 12304400 & $\begin{array}{l}\text { Fourth of } \\
\text { July Creek } \\
\text { near Yaak, } \\
\text { Montana }\end{array}$ & 48.7011 & -115.8687 & $\mathrm{CSG}$ & 15 & 7.77 & 24.8 & 44.6 & 79.6 & 59.9 & 15.9 \\
\hline 627 & 12323500 & $\begin{array}{l}\text { German Gulch } \\
\text { Creek near } \\
\text { Ramsay, } \\
\text { Montana }\end{array}$ & 46.0146 & -112.7932 & CONT & 16 & 40.9 & 52.2 & 22.4 & 13.3 & 80.7 & 52.2 \\
\hline 633 & 12324100 & $\begin{array}{l}\text { Racetrack } \\
\text { Creek below } \\
\text { Granite } \\
\text { Creek, near } \\
\text { Anaconda, } \\
\text { Montana }\end{array}$ & 46.2789 & -112.9192 & CONT & 17 & 41.1 & 53.1 & 32.8 & 48.7 & 86.2 & 74.3 \\
\hline 635 & 12324250 & $\begin{array}{l}\text { Cottonwood } \\
\text { Creek at } \\
\text { Deer Lodge, } \\
\text { Montana }\end{array}$ & 46.3997 & -112.7167 & CSG & 18 & 43.7 & 54.0 & 23.0 & 15.9 & 67.2 & 23.0 \\
\hline
\end{tabular}


Table 13. Information on discontinued streamgages in the West hydrologic region that might be candidates for reactivation to improve the streamgage network.-Continued

[NAD 83, North American Datum of 1983; $n$, total number of years of peak-flow records; CONTDA, contributing drainage area, in square miles; PRECIP, mean annual precipitation, in inches; FOREST, percentage of basin in forest; CSG, crest-stage gage; CONT, continuous streamgage]

\begin{tabular}{|c|c|c|c|c|c|c|c|c|c|c|c|c|}
\hline $\begin{array}{c}\text { Map } \\
\text { number } \\
\text { (fig. 1) }\end{array}$ & $\begin{array}{c}\text { Station } \\
\text { identification } \\
\text { number }\end{array}$ & Station name & $\begin{array}{c}\text { Latitude, } \\
\text { in decimal } \\
\text { degrees } \\
\text { (NAD 83) }\end{array}$ & $\begin{array}{l}\text { Longitude, } \\
\text { in decimal } \\
\text { degrees } \\
\text { (NAD 83) }\end{array}$ & $\begin{array}{c}\text { Type of } \\
\text { streamgage }\end{array}$ & $n$ & CONTDA & $\begin{array}{l}\text { Nonexceedance } \\
\text { percentile }^{1} \text { for } \\
\text { CONTDA }\end{array}$ & PRECIP & $\begin{array}{l}\text { Nonexceedance } \\
\text { percentile }^{1} \text { for } \\
\text { PRECIP }\end{array}$ & FOREST & $\begin{array}{l}\text { Nonexceedance } \\
\text { percentile }^{1} \text { for } \\
\text { FOREST }\end{array}$ \\
\hline 639 & 12324800 & $\begin{array}{l}\text { Morris } \\
\text { Creek near } \\
\text { Drummond, } \\
\text { Montana }\end{array}$ & 46.6655 & -113.0999 & CSG & 16 & 12.7 & 34.5 & 21.5 & 10.6 & 43.9 & 3.5 \\
\hline 655 & 12338500 & $\begin{array}{l}\text { Blackfoot River } \\
\text { near Ovando, } \\
\text { Montana }\end{array}$ & 47.0156 & -113.2288 & CONT & 25 & 1,270 & 97.3 & 26.4 & 23.0 & 65.8 & 20.4 \\
\hline 656 & 12338540 & $\begin{array}{l}\text { Monture } \\
\text { Creek above } \\
\text { Dunham } \\
\text { Creek, near } \\
\text { Ovando, } \\
\text { Montana }\end{array}$ & 47.1184 & -113.1464 & CSG & 14 & 64.5 & 59.3 & 39.3 & 65.5 & 77.1 & 45.1 \\
\hline 657 & 12338550 & $\begin{array}{l}\text { Dunham Creek } \\
\text { at mouth, } \\
\text { near Ovando, } \\
\text { Montana }\end{array}$ & 47.1233 & -113.1645 & CSG & 14 & 31.7 & 51.3 & 39.4 & 67.3 & 90.3 & 84.1 \\
\hline 659 & 12338690 & $\begin{array}{l}\text { Monture Creek } \\
\text { near Ovando, } \\
\text { Montana }\end{array}$ & 47.0453 & -113.1902 & CONT & 10 & 146 & 70.8 & 33.6 & 51.3 & 74.7 & 38.9 \\
\hline 660 & 12339300 & $\begin{array}{l}\text { Deer Creek near } \\
\text { Seeley Lake, } \\
\text { Montana }\end{array}$ & 47.2101 & -113.5416 & CSG & 18 & 19.5 & 39.8 & 39.7 & 68.1 & 83.4 & 59.3 \\
\hline 661 & 12339450 & $\begin{array}{l}\text { Clearwater } \\
\text { River near } \\
\text { Clearwater, } \\
\text { Montana }\end{array}$ & 47.0187 & -113.3877 & CONT & 19 & 346 & 82.3 & 34.3 & 54.0 & 83.3 & 58.4 \\
\hline 664 & 12340200 & $\begin{array}{l}\text { Marshall } \\
\text { Creek near } \\
\text { Missoula, } \\
\text { Montana }\end{array}$ & 46.8877 & -113.9249 & CSG & 16 & 5.67 & 16.8 & 27.3 & 28.3 & 84.8 & 64.6 \\
\hline 667 & 12342950 & $\begin{array}{c}\text { Trapper Creek } \\
\text { near Conner, } \\
\text { Montana }\end{array}$ & 45.8951 & -114.1819 & CSG & 18 & 28.4 & 49.6 & 40.8 & 71.7 & 61.6 & 16.8 \\
\hline
\end{tabular}


Table 13. Information on discontinued streamgages in the West hydrologic region that might be candidates for reactivation to improve the streamgage network.-Continued [NAD 83, North American Datum of 1983; $n$, total number of years of peak-flow records; CONTDA, contributing drainage area, in square miles; PRECIP, mean annual precipitation, in inches; FOREST, percentage of basin in forest; CSG, crest-stage gage; CONT, continuous streamgage]

\begin{tabular}{|c|c|c|c|c|c|c|c|c|c|c|c|c|}
\hline $\begin{array}{c}\text { Map } \\
\text { number } \\
\text { (fig. 1) }\end{array}$ & $\begin{array}{c}\text { Station } \\
\text { identification } \\
\text { number }\end{array}$ & Station name & $\begin{array}{c}\text { Latitude, } \\
\text { in decimal } \\
\text { degrees } \\
\text { (NAD 83) }\end{array}$ & $\begin{array}{c}\text { Longitude, } \\
\text { in decimal } \\
\text { degrees } \\
\text { (NAD 83) }\end{array}$ & $\begin{array}{c}\text { Type of } \\
\text { streamgage }\end{array}$ & $n$ & CONTDA & $\begin{array}{l}\text { Nonexceedance } \\
\text { percentile }^{1} \text { for } \\
\text { CONTDA }\end{array}$ & PRECIP & $\begin{array}{l}\text { Nonexceedance } \\
\text { percentile }^{1} \text { for } \\
\text { PRECIP }\end{array}$ & FOREST & $\begin{array}{l}\text { Nonexceedance } \\
\text { percentile }^{1} \text { for } \\
\text { FOREST }\end{array}$ \\
\hline 668 & 12343300 & $\begin{array}{c}\text { Laird Creek } \\
\text { near Sula, } \\
\text { Montana }\end{array}$ & 45.8736 & -114.0535 & CONT & 12 & 9.45 & 28.3 & 32.9 & 49.6 & 71.3 & 30.1 \\
\hline 673 & 12345800 & $\begin{array}{l}\text { Camas } \\
\text { Creek near } \\
\text { Hamilton, } \\
\text { Montana }\end{array}$ & 46.1445 & -114.2136 & CSG & 16 & 5.27 & 14.2 & 48.5 & 86.7 & 58.9 & 14.2 \\
\hline 674 & 12345850 & $\begin{array}{l}\text { Sleeping Child } \\
\text { Creek near } \\
\text { Hamilton, } \\
\text { Montana }\end{array}$ & 46.1324 & -114.0582 & $\begin{array}{r}\mathrm{CONT} \\
\mathrm{CSG}\end{array}$ & 20 & 65.9 & 60.2 & 27.1 & 27.4 & 87.8 & 76.1 \\
\hline 676 & 12347500 & $\begin{array}{l}\text { Blodgett } \\
\text { Creek near } \\
\text { Corvallis, } \\
\text { Montana }\end{array}$ & 46.2694 & -114.2371 & CONT & 24 & 25.9 & 46.9 & 50.4 & 90.3 & 49.3 & 8.8 \\
\hline 677 & 12348500 & $\begin{array}{l}\text { Willow } \\
\text { Creek near } \\
\text { Corvallis, } \\
\text { Montana }\end{array}$ & 46.2954 & -113.9955 & CONT & 19 & 22.6 & 42.5 & 28.6 & 32.7 & 88.7 & 79.6 \\
\hline 678 & 12350000 & $\begin{array}{c}\text { Bear Creek } \\
\text { near Victor, } \\
\text { Montana }\end{array}$ & 46.3809 & -114.2204 & CONT & 19 & 27.4 & 47.8 & 43.0 & 77.0 & 66.8 & 22.1 \\
\hline 679 & 12350200 & $\begin{array}{c}\text { Gash Creek } \\
\text { near Victor, } \\
\text { Montana }\end{array}$ & 46.4055 & -114.2566 & CSG & 16 & 2.76 & 7.1 & 39.3 & 66.4 & 79.3 & 49.6 \\
\hline 681 & 12350500 & $\begin{array}{l}\text { Kootenai } \\
\text { Creek near } \\
\text { Stevensville, } \\
\text { Montana }\end{array}$ & 46.5368 & -114.1596 & $\begin{array}{r}\text { CONT, } \\
\text { CSG }\end{array}$ & 22 & 28.9 & 50.4 & 42.5 & 73.5 & 66.1 & 21.2 \\
\hline 683 & 12351200 & $\begin{array}{l}\text { Bitterroot } \\
\text { River near } \\
\text { Florence, } \\
\text { Montana }\end{array}$ & 46.6331 & -114.0510 & CONT & 20 & 2,342 & 99.1 & 30.6 & 41.6 & 61.7 & 17.7 \\
\hline
\end{tabular}


Table 13. Information on discontinued streamgages in the West hydrologic region that might be candidates for reactivation to improve the streamgage network.-Continued

[NAD 83, North American Datum of 1983; $n$, total number of years of peak-flow records; CONTDA, contributing drainage area, in square miles; PRECIP, mean annual precipitation, in inches; FOREST, percentage of basin in forest; CSG, crest-stage gage; CONT, continuous streamgage]

\begin{tabular}{|c|c|c|c|c|c|c|c|c|c|c|c|c|}
\hline $\begin{array}{c}\text { Map } \\
\text { number } \\
\text { (fig. 1) }\end{array}$ & $\begin{array}{c}\text { Station } \\
\text { identification } \\
\text { number }\end{array}$ & Station name & $\begin{array}{l}\text { Latitude, } \\
\text { in decimal } \\
\text { degrees } \\
\text { (NAD 83) }\end{array}$ & $\begin{array}{c}\text { Longitude, } \\
\text { in decimal } \\
\text { degrees } \\
\text { (NAD 83) }\end{array}$ & $\begin{array}{c}\text { Type of } \\
\text { streamgage }\end{array}$ & $n$ & CONTDA & $\begin{array}{l}\text { Nonexceedance } \\
\text { percentile }{ }^{1} \text { for } \\
\text { CONTDA }\end{array}$ & PRECIP & $\begin{array}{c}\text { Nonexceedance } \\
\text { percentile }{ }^{1} \text { for } \\
\text { PRECIP }\end{array}$ & FOREST & $\begin{array}{l}\text { Nonexceedance } \\
\text { percentile }{ }^{1} \text { for } \\
\text { FOREST }\end{array}$ \\
\hline 684 & 12351400 & $\begin{array}{l}\text { Eightmile } \\
\text { Creek near } \\
\text { Florence, } \\
\text { Montana }\end{array}$ & 46.6486 & -113.9582 & CONT & 16 & 20.9 & 41.6 & 28.7 & 34.5 & 70.1 & 27.4 \\
\hline 685 & 12352000 & $\begin{array}{l}\text { Lolo Creek } \\
\text { above } \\
\text { Sleeman } \\
\text { Creek, } \\
\text { near Lolo, } \\
\text { Montana }\end{array}$ & 46.7441 & -114.1434 & CONT & 12 & 250 & 78.8 & 38.4 & 61.1 & 81.7 & 55.8 \\
\hline 686 & 12352200 & $\begin{array}{l}\text { Hays Creek } \\
\text { near } \\
\text { Missoula, } \\
\text { Montana }\end{array}$ & 46.8132 & -114.0939 & CSG & 16 & 4.13 & 11.5 & 26.8 & 24.8 & 86.7 & 75.2 \\
\hline 689 & 12353250 & $\begin{array}{l}\text { Ninemile } \\
\text { Creek near } \\
\text { Alberton, } \\
\text { Montana }\end{array}$ & 47.1859 & -114.5872 & CSG & 10 & 49.2 & 56.6 & 32.6 & 47.8 & 79.1 & 48.7 \\
\hline 690 & 12353280 & $\begin{array}{l}\text { Ninemile Creek } \\
\text { near Huson, } \\
\text { Montana }\end{array}$ & 47.0634 & -114.4138 & CONT & 10 & 170 & 72.6 & 29.7 & 37.2 & 85.2 & 66.4 \\
\hline 691 & 12353400 & $\begin{array}{l}\text { Negro Gulch } \\
\text { near } \\
\text { Alberton, } \\
\text { Montana }\end{array}$ & 47.0207 & -114.5229 & CSG & 23 & 8.07 & 25.7 & 29.0 & 35.4 & 76.7 & 43.4 \\
\hline 692 & 12353800 & $\begin{array}{l}\text { Thompson } \\
\text { Creek near } \\
\text { Superior, } \\
\text { Montana }\end{array}$ & 47.1991 & -114.9171 & CSG & 20 & 12.0 & 32.7 & 38.9 & 62.8 & 78.2 & 46.9 \\
\hline 693 & 12353820 & $\begin{array}{l}\text { Dry Creek near } \\
\text { Superior, } \\
\text { Montana }\end{array}$ & 47.2214 & -114.9732 & CONT & 10 & 44.8 & 54.9 & 48.9 & 87.6 & 77.0 & 44.2 \\
\hline
\end{tabular}


Table 13. Information on discontinued streamgages in the West hydrologic region that might be candidates for reactivation to improve the streamgage network.-Continued [NAD 83, North American Datum of 1983; $n$, total number of years of peak-flow records; CONTDA, contributing drainage area, in square miles; PRECIP, mean annual precipitation, in inches; FOREST, percentage of basin in forest; CSG, crest-stage gage; CONT, continuous streamgage]

\begin{tabular}{|c|c|c|c|c|c|c|c|c|c|c|c|c|}
\hline $\begin{array}{c}\text { Map } \\
\text { number } \\
\text { (fig. 1) }\end{array}$ & $\begin{array}{c}\text { Station } \\
\text { identification } \\
\text { number }\end{array}$ & Station name & $\begin{array}{l}\text { Latitude, } \\
\text { in decimal } \\
\text { degrees } \\
\text { (NAD 83) }\end{array}$ & $\begin{array}{l}\text { Longitude, } \\
\text { in decimal } \\
\text { degrees } \\
\text { (NAD 83) }\end{array}$ & $\begin{array}{c}\text { Type of } \\
\text { streamgage }\end{array}$ & $n$ & CONTDA & $\begin{array}{c}\text { Nonexceedance } \\
\text { percentile }{ }^{1} \text { for } \\
\text { CONTDA }\end{array}$ & PRECIP & $\begin{array}{l}\text { Nonexceedance } \\
\text { percentile }^{1} \text { for } \\
\text { PRECIP }\end{array}$ & FOREST & $\begin{array}{l}\text { Nonexceedance } \\
\text { percentile }^{1} \text { for } \\
\text { FOREST }\end{array}$ \\
\hline 694 & 12353850 & $\begin{array}{l}\text { East Fork } \\
\text { Timber Creek } \\
\text { near Haugan, } \\
\text { Montana }\end{array}$ & 47.4133 & -115.4134 & CSG & 16 & 2.77 & 8.0 & 32.5 & 46.9 & 90.0 & 83.2 \\
\hline 696 & 12354100 & $\begin{array}{l}\text { North Fork } \\
\text { Little Joe } \\
\text { Creek near } \\
\text { St. Regis, } \\
\text { Montana }\end{array}$ & 47.2700 & -115.1428 & CSG & 15 & 14.6 & 36.3 & 44.5 & 78.8 & 88.2 & 77.0 \\
\hline 699 & 12355350 & $\begin{array}{l}\text { Big Creek at } \\
\text { Big Creek } \\
\text { Ranger } \\
\text { Station, near } \\
\text { Columbia } \\
\text { Falls, } \\
\text { Montana }\end{array}$ & 48.6017 & -114.1667 & CSG & 20 & 81.8 & 63.7 & 45.4 & 80.5 & 92.8 & 89.4 \\
\hline 717 & 12363900 & $\begin{array}{l}\text { Rock Creek } \\
\text { near Olney, } \\
\text { Montana }\end{array}$ & 48.6122 & -114.6519 & CSG & 15 & 7.64 & 23.9 & 40.6 & 69.9 & 88.6 & 77.9 \\
\hline 718 & 12363920 & $\begin{array}{l}\text { Stillwater River } \\
\text { at Olney, } \\
\text { Montana }\end{array}$ & 48.5355 & -114.5717 & CONT & 10 & 162 & 71.7 & 35.8 & 56.6 & 84.3 & 61.1 \\
\hline 719 & 12364000 & $\begin{array}{l}\text { Logan Creek } \\
\text { at Tally } \\
\text { Lake, near } \\
\text { Whitefish, } \\
\text { Montana }\end{array}$ & 48.4507 & -114.5686 & CONT & 10 & 184 & 75.2 & 25.4 & 19.5 & 76.4 & 41.6 \\
\hline 724 & 12367500 & $\begin{array}{l}\text { Ashley } \\
\text { Creek near } \\
\text { Kalispell, } \\
\text { Montana }\end{array}$ & 48.1650 & -114.4324 & CONT & 20 & 201 & 76.1 & 20.6 & 7.1 & 71.6 & 31.0 \\
\hline 725 & 12369200 & $\begin{array}{l}\text { Swan River } \\
\text { near Condon, } \\
\text { Montana }\end{array}$ & 47.4224 & -113.6710 & CONT & 20 & 69.1 & 61.1 & 49.7 & 89.4 & 74.1 & 38.1 \\
\hline
\end{tabular}


Table 13. Information on discontinued streamgages in the West hydrologic region that might be candidates for reactivation to improve the streamgage network.-Continued

[NAD 83, North American Datum of 1983; $n$, total number of years of peak-flow records; CONTDA, contributing drainage area, in square miles; PRECIP, mean annual precipitation, in inches; FOREST, percentage of basin in forest; CSG, crest-stage gage; CONT, continuous streamgage]

\begin{tabular}{|c|c|c|c|c|c|c|c|c|c|c|c|c|}
\hline $\begin{array}{c}\text { Map } \\
\text { number } \\
\text { (fig. 1) }\end{array}$ & $\begin{array}{c}\text { Station } \\
\text { identification } \\
\text { number }\end{array}$ & Station name & $\begin{array}{l}\text { Latitude, } \\
\text { in decimal } \\
\text { degrees } \\
\text { (NAD 83) }\end{array}$ & $\begin{array}{c}\text { Longitude, } \\
\text { in decimal } \\
\text { degrees } \\
\text { (NAD 83) }\end{array}$ & $\begin{array}{c}\text { Type of } \\
\text { streamgage }\end{array}$ & $n$ & CONTDA & $\begin{array}{l}\text { Nonexceedance } \\
\text { percentile }^{1} \text { for } \\
\text { CONTDA }\end{array}$ & PRECIP & $\begin{array}{l}\text { Nonexceedance } \\
\text { percentile }^{1} \text { for } \\
\text { PRECIP }\end{array}$ & FOREST & $\begin{array}{l}\text { Nonexceedance } \\
\text { percentile }^{1} \text { for } \\
\text { FOREST }\end{array}$ \\
\hline 726 & 12369250 & $\begin{array}{l}\text { Holland Creek } \\
\text { near Condon, } \\
\text { Montana }\end{array}$ & 47.4389 & -113.6704 & CSG & 18 & 22.6 & 42.5 & 37.2 & 59.3 & 81.5 & 54.9 \\
\hline 727 & 12369650 & $\begin{array}{c}\text { North Fork Lost } \\
\text { Creek near } \\
\text { Swan Lake, } \\
\text { Montana }\end{array}$ & 47.8848 & -113.7989 & $\begin{array}{r}\mathrm{CONT}, \\
\mathrm{CSG}\end{array}$ & 10 & 13.1 & 35.4 & 58.8 & 95.6 & 80.1 & 50.4 \\
\hline 730 & 12370900 & $\begin{array}{c}\text { Teepee Creek } \\
\text { near Polson, } \\
\text { Montana }\end{array}$ & 47.8215 & -114.0234 & $\begin{array}{r}\mathrm{CONT}, \\
\mathrm{CSG}\end{array}$ & 21 & 2.11 & 3.5 & 46.9 & 84.1 & 88.7 & 78.8 \\
\hline 735 & 12375700 & $\begin{array}{c}\text { Garden Creek } \\
\text { near Hot } \\
\text { Springs, } \\
\text { Montana }\end{array}$ & 47.6484 & -114.6930 & CSG & 15 & 3.67 & 10.6 & 25.5 & 20.4 & 95.6 & 96.5 \\
\hline 737 & 12376000 & $\begin{array}{c}\text { Crow Creek } \\
\text { near Ronan, } \\
\text { Montana }\end{array}$ & 47.4866 & -114.0944 & CONT & 10 & 48.4 & 55.8 & 36.2 & 58.4 & 71.8 & 33.6 \\
\hline 743 & 12388200 & $\begin{array}{c}\text { Jocko River } \\
\text { at Dixon, } \\
\text { Montana }\end{array}$ & 47.3121 & -114.2974 & CONT & 21 & 383 & 84.1 & 32.5 & 46.0 & 71.6 & 32.7 \\
\hline 747 & 12389150 & $\begin{array}{l}\text { McGregor } \\
\text { Creek } \\
\text { tributary } \\
\text { near Marion, } \\
\text { Montana }\end{array}$ & 48.0283 & -114.9324 & CSG & 11 & 2.54 & 6.2 & 25.6 & 21.2 & 70.0 & 26.5 \\
\hline 750 & 12391100 & $\begin{array}{l}\text { White Pine } \\
\text { Creek near } \\
\text { Trout Creek, } \\
\text { Montana }\end{array}$ & 47.7394 & -115.6738 & CSG & 11 & 8.85 & 27.4 & 53.3 & 94.7 & 93.8 & 92.9 \\
\hline 751 & 12391200 & $\begin{array}{c}\text { Canyon Creek } \\
\text { near Trout } \\
\text { Creek, } \\
\text { Montana }\end{array}$ & 47.8545 & -115.5004 & $\mathrm{CSG}$ & 19 & 8.67 & 26.5 & 47.6 & 85.8 & 92.0 & 87.6 \\
\hline
\end{tabular}


Table 13. Information on discontinued streamgages in the West hydrologic region that might be candidates for reactivation to improve the streamgage network.-Continued [NAD 83, North American Datum of 1983; $n$, total number of years of peak-flow records; CONTDA, contributing drainage area, in square miles; PRECIP, mean annual precipitation, in inches; FOREST, percentage of basin in forest; CSG, crest-stage gage; CONT, continuous streamgage]

\begin{tabular}{|c|c|c|c|c|c|c|c|c|c|c|c|c|}
\hline $\begin{array}{c}\text { Map } \\
\text { number } \\
\text { (fig. 1) }\end{array}$ & $\begin{array}{c}\text { Station } \\
\text { identification } \\
\text { number }\end{array}$ & Station name & $\begin{array}{c}\text { Latitude, } \\
\text { in decimal } \\
\text { degrees } \\
\text { (NAD 83) }\end{array}$ & $\begin{array}{c}\text { Longitude, } \\
\text { in decimal } \\
\text { degrees } \\
\text { (NAD 83) }\end{array}$ & $\begin{array}{c}\text { Type of } \\
\text { streamgage }\end{array}$ & $n$ & CONTDA & $\begin{array}{l}\text { Nonexceedance } \\
\text { percentile }{ }^{1} \text { for } \\
\text { CONTDA }\end{array}$ & PRECIP & $\begin{array}{c}\text { Nonexceedance } \\
\text { percentile }{ }^{1} \text { for } \\
\text { PRECIP }\end{array}$ & FOREST & $\begin{array}{l}\text { Nonexceedance } \\
\text { percentile }{ }^{1} \text { for } \\
\text { FOREST }\end{array}$ \\
\hline 753 & 12391430 & $\begin{array}{c}\text { Skeleton Creek } \\
\text { near Noxon, } \\
\text { Montana }\end{array}$ & 47.9628 & -115.8910 & CSG & 12 & 2.03 & 2.7 & 52.6 & 93.8 & 97.0 & 99.1 \\
\hline 754 & 12391525 & $\begin{array}{c}\text { Snake Creek } \\
\text { near Noxon, } \\
\text { Montana }\end{array}$ & 48.1230 & -115.7544 & $\mathrm{CSG}$ & 13 & 3.22 & 9.7 & 42.8 & 75.2 & 99.0 & 100.0 \\
\hline 755 & 12391550 & $\begin{array}{l}\text { Bull River } \\
\text { near Noxon, } \\
\text { Montana }\end{array}$ & 48.0474 & -115.8350 & CONT & 10 & 141 & 69.9 & 52.3 & 92.0 & 85.3 & 67.3 \\
\hline
\end{tabular}

${ }^{1}$ The nonexceedance percentile for the basin or climatic variable value was calculated in relation to the values for all streamgages included in the regional regression analyses for the indicated hydrologic region. 

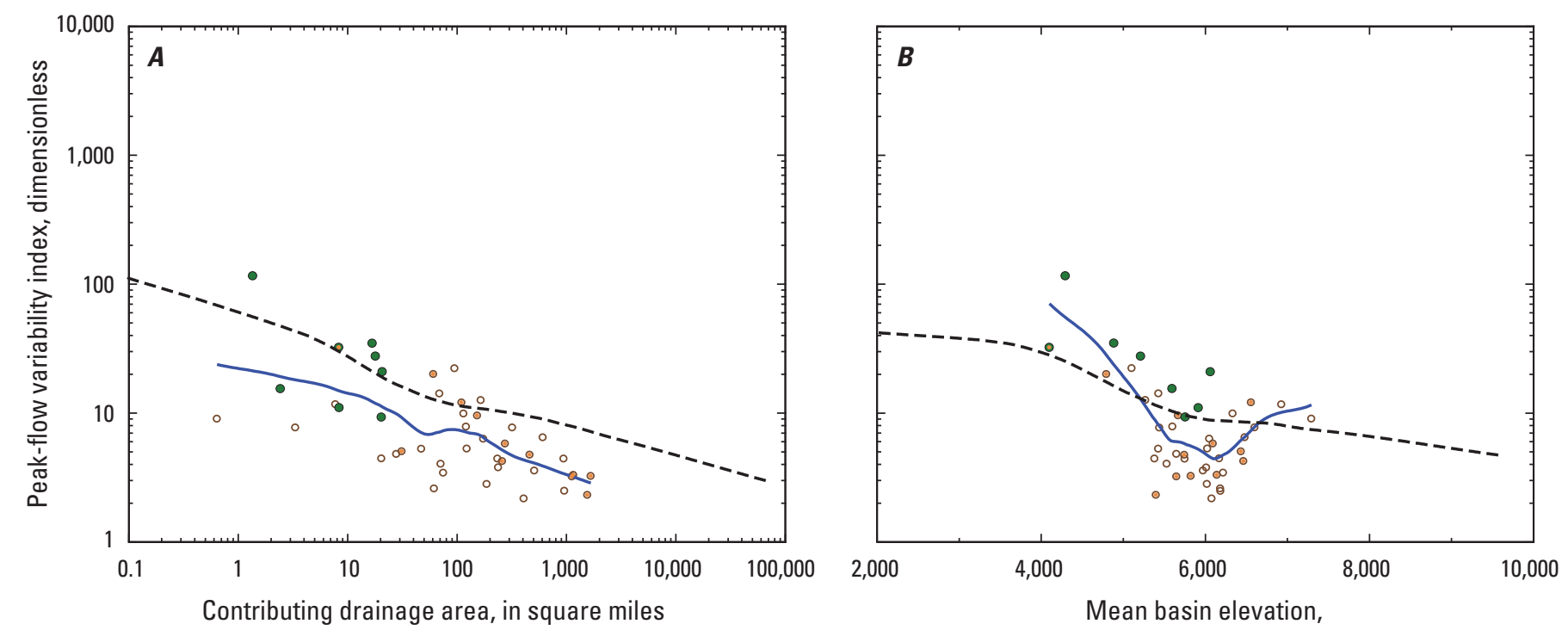

in feet above the North American Vertical Datum of 1988
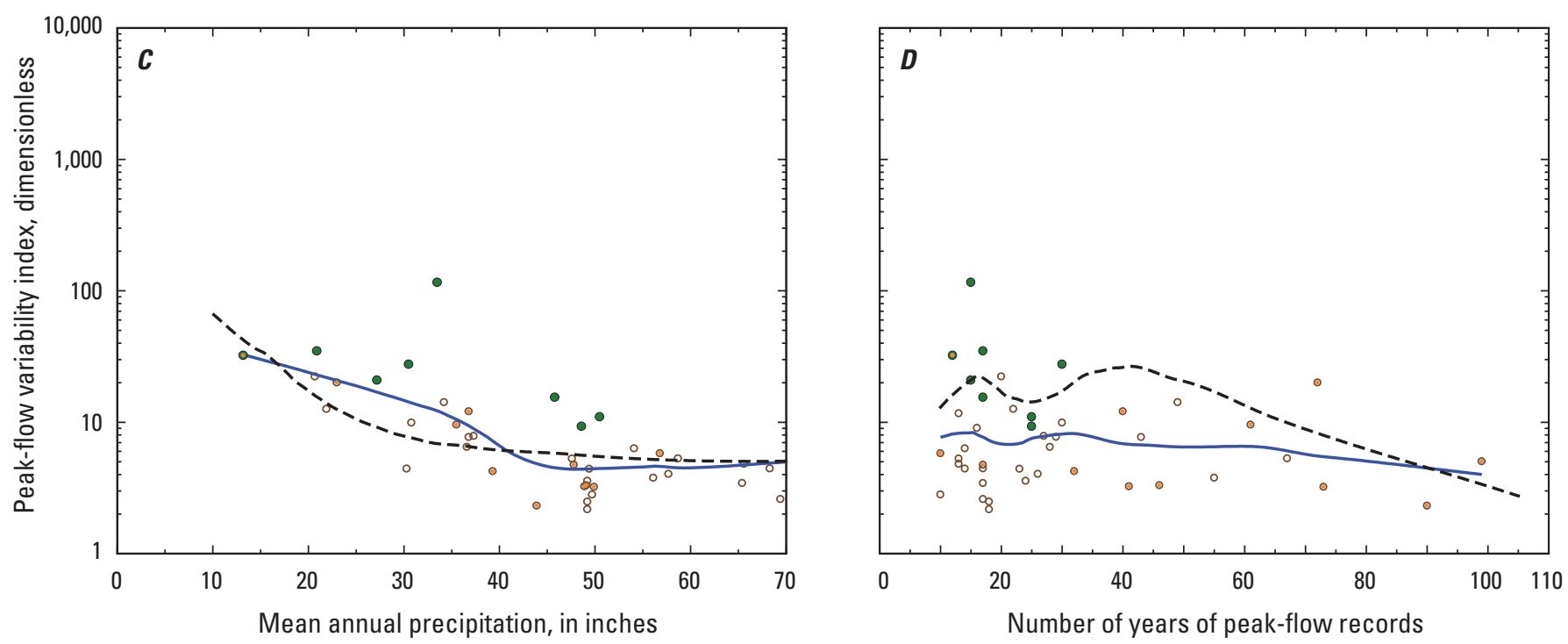

\section{EXPLANATION}

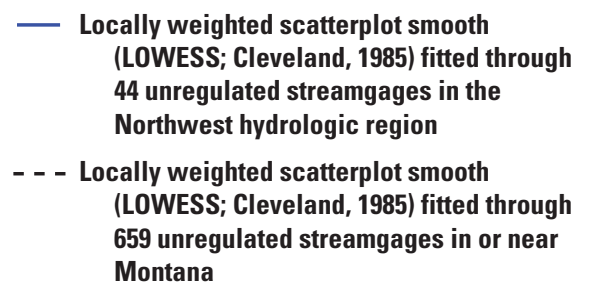

- Crest-stage streamgage

- Continuous streamgage

Interior dot denotes active streamgage in water year 2017

Figure 9. Relations between peak-flow variability index and contributing drainage area, mean basin elevation, mean annual precipitation, and years of peak-flow records for 44 unregulated streamgages in the Northwest hydrologic region. $A$, peak-flow variability and contributing drainage area relations. $B$, Peak-flow variability and mean basin elevation relations. $C$, Peak-flow variability and mean annual precipitation relations. $D$, Peak-flow variability and years of peak-flow records relations. 


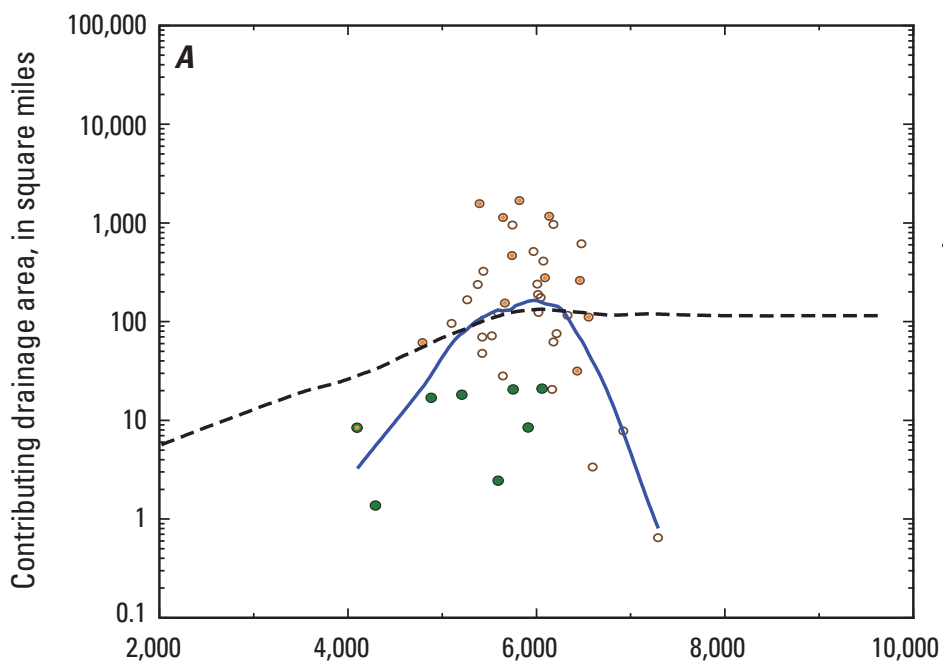

\section{EXPLANATION}

Locally weighted scatterplot smooth (LOWESS; Cleveland, 1985) fitted through 44 unregulated streamgages in the Northwest hydrologic region

- - - Locally weighted scatterplot smooth (LOWESS; Cleveland, 1985) fitted through 659 unregulated streamgages in or near Montana

- Crest-stage streamgage

- Continuous streamgage

- Interior dot denotes active streamgage in water year 2017

Mean basin elevation, in feet above the North American Vertical Datum of 1988
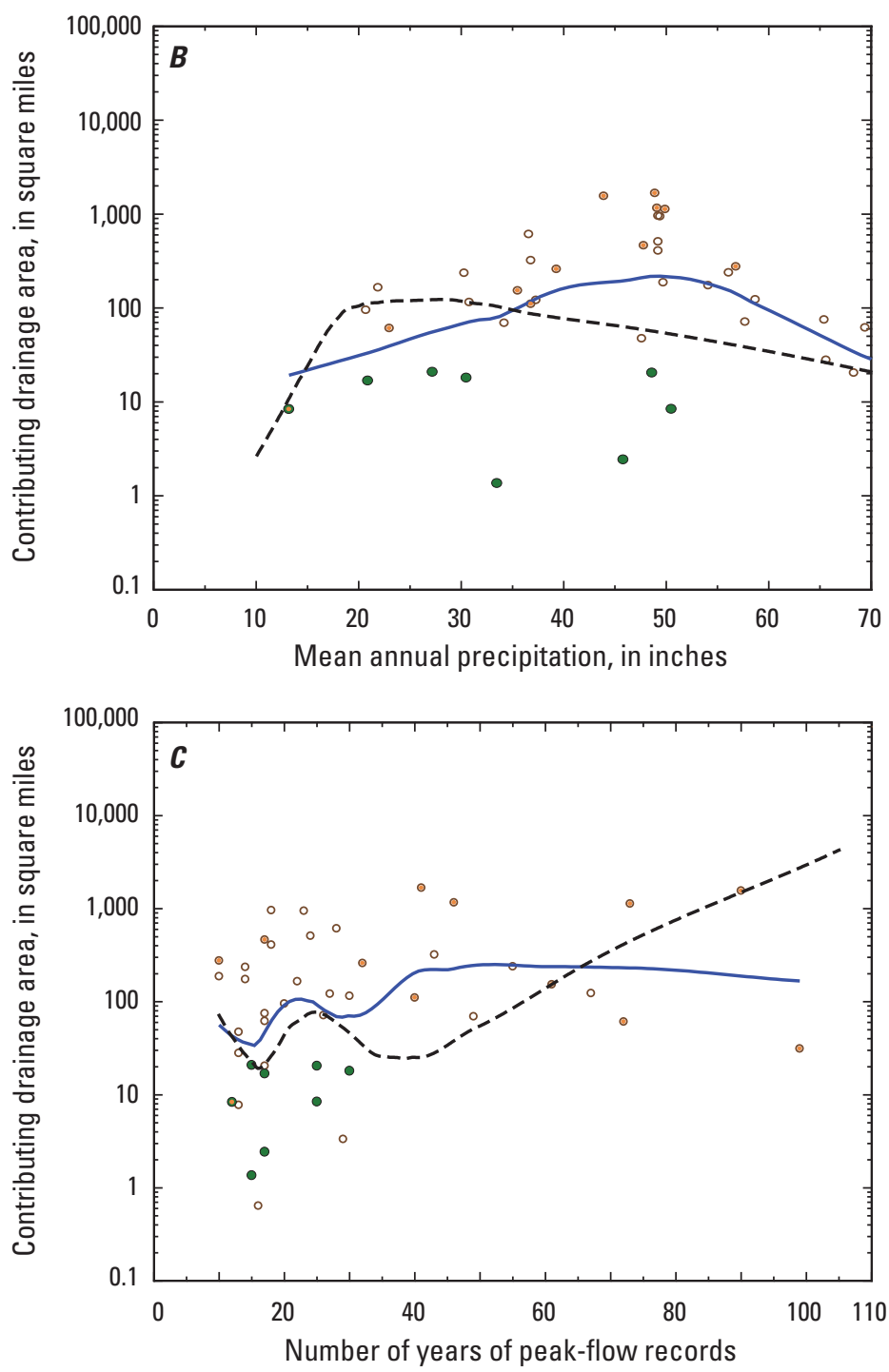

Figure 10. Relations between contributing drainage area and mean basin elevation, mean annual precipitation, and years of peak-flow records for 44 unregulated streamgages in the Northwest hydrologic region. $A$, Contributing drainage area and mean basin elevation relations. $B$, Contributing drainage area and mean annual precipitation relations. $C$, Contributing drainage area and years of peak-flow records relations. 
Information on streamgages in the Northwest hydrologic region with significant leverage and influence is presented in table 14. Three of the four significant leverage streamgages have high CONTDA values (nonexceedance percentiles greater than about 93 percent) and one streamgage has a low $C O N$ $T D A$ value (nonexceedance percentile less than about 4 percent). Three of the four streamgages with significant influence have positive residuals for the 1-percent AEP RRE.

In general, the streamgage network in the Northwest hydrologic region is considered to provide generally reasonable representation of the hydroclimatic settings of that hydrologic region. The RREs of the Northwest hydrologic region are considered to be generally reliable but are affected by a large proportion of mixed-population peak-flow datasets that currently (2020) are not well handled in the Bulletin 17C frequency-analysis approaches and are noted as needing further research (England and others, 2019). Possible shortcomings of the streamgage network in the Northwest hydrologic region include possible underrepresentation of basins with drainage area less than about $125 \mathrm{mi}^{2}$, mean basin elevation less than about 5,400 ft, and (or) mean annual precipitation less than about 37 inches. Future improvements to the streamgage network in the Northwest hydrologic region might include establishing new CSGs or reactivating discontinued streamgages as CSGs on drainage basins with the specified characteristics. Information on discontinued streamgages in the Northwest hydrologic region that might be candidates for reactivation to improve the streamgage network is presented in table 15 .

\section{Peak-Flow Variability, Peak-Flow Informational Needs, and Consideration of Regional Regression Analyses in the Northwest Foothills Hydrologic Region}

The Northwest Foothills hydrologic region has an area of 10,624 $\mathrm{mi}^{2}$ (table 1), which ranks seventh largest among the eight hydrologic regions. Level III ecoregions (table 2) represented in the Northwest Foothills hydrologic region include the Middle Rockies (1.8 percent), Northwestern Glaciated Plains (98.1 percent), and Northwestern Great Plains ( 0.2 percent). The 1,043 road and stream intersections in the Northwest Foothills hydrologic region (tables 4 and 5) represent a density of 0.098 road and stream intersection per $\mathrm{mi}^{2}$, which ranks third among the hydrologic regions. The 46 streamgages (both regulated and unregulated; tables 4 and 5) represent an areal density of 0.00433 streamgage per $\mathrm{mi}^{2}$ (ranking fifth among hydrologic regions) and a density of 0.04410 streamgage per road and stream intersection (ranking seventh among hydrologic regions).

Relations between $P F V I$ and contributing drainage area, mean basin elevation, mean annual precipitation, and years of peak-flow records for 40 unregulated streamgages in the Northwest Foothills hydrologic region (table 3) are presented in figure 12. In general, the small number of unregulated streamgages in the Northwest Foothills hydrologic region relative to the other hydrologic regions makes it more difficult to discern clear patterns in the various relations.

For 40 unregulated streamgages in the Northwest Foothills hydrologic region, PFVI generally monotonically decreases with increasing drainage area (fig. 12A) with generally small and consistent variability about the LOWESS line. Intuitively, highly variable small-scale hydroclimatic processes are integrated with increasing drainage area such that variability in many hydrologic characteristics is reduced. $P F V I$ also generally decreases with increasing elevation (fig. 12B), and precipitation (fig. 12C). The small number of streamgages with more than 40 years of peak-flow records makes it difficult to discern clear patterns in the PFVI and years of record relations (fig. 12D). For the relations between $P F V I$ and drainage area (fig. 12A), elevation (fig. 12B), and years of record (fig. 12D), the LOWESS lines for the Northwest Foothills hydrologic region generally are similar to the LOWESS lines for all unregulated streamgages in Montana.

Relations between contributing drainage area and mean basin elevation, mean annual precipitation, and years of peakflow records for the unregulated streamgages are presented in figure 13. Relations between contributing drainage area and mean basin elevation (fig. 13A) indicate that streamgages with smaller drainage areas (less than about $30 \mathrm{mi}^{2}$ ) are predominantly located at lower elevations (ranging from about 2,740 to $4,550 \mathrm{ft}$ ) and streamgages with larger drainage areas (greater than about $50 \mathrm{mi}^{2}$ ) are predominantly located at higher elevations (ranging from about 3,440 to 6,385 ft). Similarly, relations between contributing drainage area and mean annual precipitation (fig. 13B) indicate that streamgages with smaller drainage areas (less than about $30 \mathrm{mi}^{2}$ ) are predominantly located in lower mean annual precipitation areas (ranging from about 10 to 17 inches) and streamgages with larger drainage areas (greater than about $50 \mathrm{mi}^{2}$ ) are predominantly located at higher elevations (ranging from about 12 to 25 inches). Streamgages with greater than about 40 years of record are predominantly located on streams with contributing drainage areas greater than about $100 \mathrm{mi}^{2}$ (fig. 13C).

The median PFVI value for streamgages in the Northwest Foothills hydrologic region (27.17, table 3 ) is larger than the median for all unregulated streamgages in Montana (18.26, table 3) and ranks as the fourth largest median PFVI among the eight hydrologic regions. For unregulated streamgages in the Northwest Foothills hydrologic region, fall and winter (October-February) precipitation accounts for about 17.5 percent of annual precipitation (table 8), which is less than any other hydrologic region. May-June precipitation accounts for about 36.7 percent of annual precipitation (table 8), which ranks second among the hydrologic regions, and July-August precipitation accounts for 21.1 percent of annual precipitation, which ranks third among the eight hydrologic regions. In the Northwest Foothills hydrologic region, annual peak flows are most frequently in March and June (fig. 2 of Sando, R., and others, 2018), probably resulting from low-elevation snowmelt runoff and springtime rainfall runoff, respectively; 

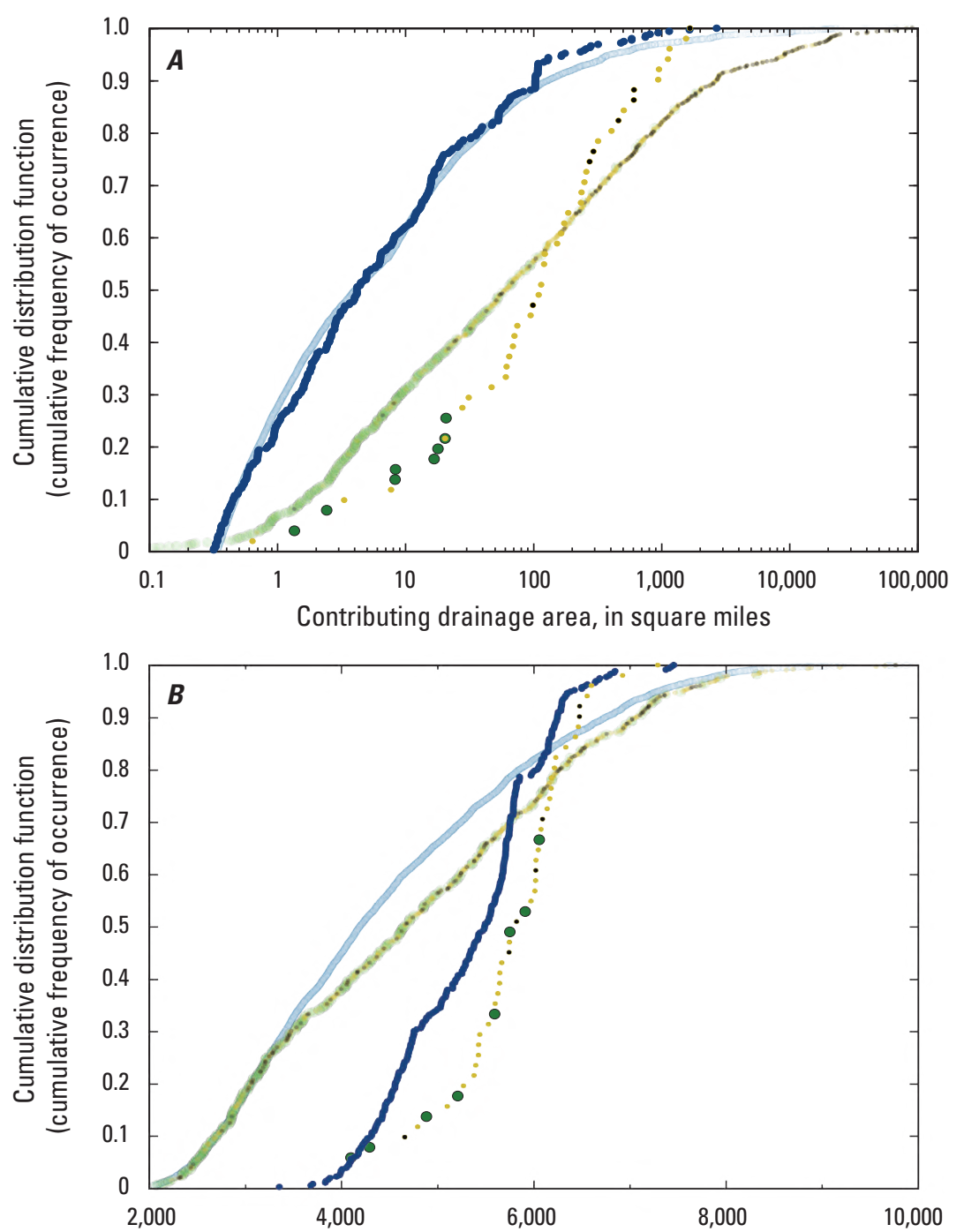

Mean basin elevation, in feet above the North American Vertical Datum of 1988

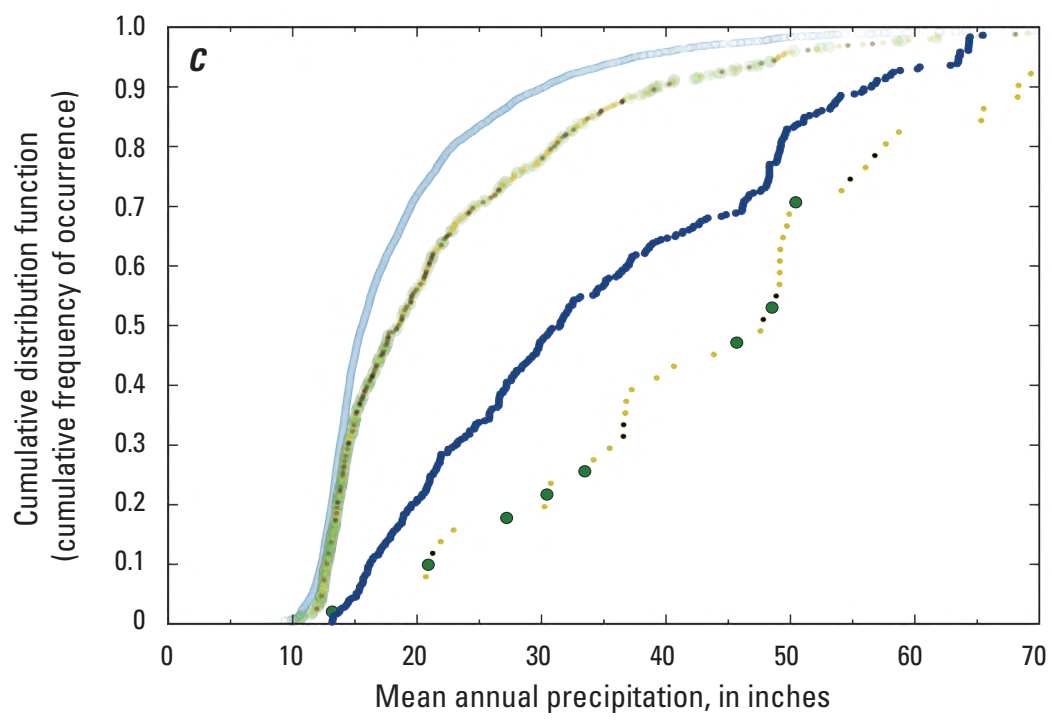

\section{EXPLANATION}

- Road and stream intersection in the Northwest hydrologic region

One of 12,639 road and stream intersections in Montana, as shown in figure $\mathbf{5}-0$ pen symbols appear as solid symbols because of the high data density

Regulated and unregulated streamgages in the Northwest hydrologic region

- Crest-stage streamgage

Unregulated continuous streamgage

- Regulated continuous streamgage

Regulated and unregulated streamgages in or near Montana, as shown in figure 5

Crest-stage streamgage in or near Montana Unregulated streamgages in or near Montana

- Regulated streamgages in or near Montana

Figure 11. Cumulative distribution functions of selected drainage-basin characteristics for 356 road and stream intersections and for 49 streamgages (regulated and unregulated) in the Northwest hydrologic region. $A$, Contributing drainage area relations. $B$, Mean basin elevation relations. $C$, Mean annual precipitation relations. 
Table 14. Information on streamgages in the Northwest hydrologic region with significant leverage and influence in the Montana regional regression analyses (Sando, R., and others, 2018).

[NAD 83, North American Datum of 1983; $n$, total number of years of peak-flow records; CONTDA, contributing drainage area, in square miles; AEP, annual exceedance probability; CONT, continuous streamgage; CSG, crest-stage gage]

\begin{tabular}{|c|c|c|c|c|c|c|c|c|c|c|c|c|}
\hline \multirow{2}{*}{$\begin{array}{l}\text { Map } \\
\text { number } \\
\text { (fig. 1) }\end{array}$} & \multirow{2}{*}{$\begin{array}{c}\text { Station } \\
\text { identification } \\
\text { number }\end{array}$} & \multirow{2}{*}{ Station name } & \multirow{2}{*}{$\begin{array}{l}\text { Latitude, } \\
\text { in decimal } \\
\text { degrees } \\
\text { (NAD 83) }\end{array}$} & \multirow{2}{*}{$\begin{array}{c}\text { Longitude, } \\
\text { in decimal } \\
\text { degrees } \\
\text { (NAD 83) }\end{array}$} & \multirow{2}{*}{$\begin{array}{c}\text { Type of } \\
\text { streamgage }\end{array}$} & \multirow{2}{*}{$\begin{array}{c}\text { Status of } \\
\text { streamgage } \\
\text { in water } \\
\text { year } 2017\end{array}$} & \multirow[t]{2}{*}{$n$} & \multirow{2}{*}{ CONTDA } & \multirow{2}{*}{$\begin{array}{l}\text { Nonexceedance } \\
\text { percentile }^{1} \text { for } \\
\text { CONTDA }\end{array}$} & \multicolumn{3}{|c|}{$\begin{array}{l}\text { Regression residuals for the } \\
\text { specified annual AEP } \\
\text { regression analyses }\end{array}$} \\
\hline & & & & & & & & & & $\begin{array}{c}\text { 10-percent } \\
\text { AEP }\end{array}$ & $\begin{array}{c}\text { 4-percent } \\
\text { AEP }\end{array}$ & $\begin{array}{c}\text { 1-percent } \\
\text { AEP }\end{array}$ \\
\hline \multicolumn{13}{|c|}{ Streamgages with significant leverage } \\
\hline 700 & 12355500 & $\begin{array}{l}\text { North Fork Flathead } \\
\text { River near Columbia } \\
\text { Falls, Montana }\end{array}$ & 48.4958 & -114.1268 & CONT & Active & 95 & 1,556 & 100.0 & 0.035 & -0.023 & -0.063 \\
\hline 705 & ${ }^{2} 12357300$ & $\begin{array}{l}\text { Moccasin Creek } \\
\text { near West Glacier, } \\
\text { Montana }\end{array}$ & 48.4811 & -113.8479 & CSG & Discontinued & 17 & 2.43 & 3.1 & 0.363 & 0.409 & 0.465 \\
\hline 708 & ${ }^{2} 12358500$ & $\begin{array}{l}\text { Middle Fork Flathead } \\
\text { River near West } \\
\text { Glacier, Montana }\end{array}$ & 48.4955 & -114.0102 & CONT & Active & 78 & 1,125 & 93.8 & 0.198 & 0.177 & 0.191 \\
\hline 711 & 12359800 & $\begin{array}{l}\text { South Fork Flathead } \\
\text { River above Twin } \\
\text { Creek, near Hungry } \\
\text { Horse, Montana }\end{array}$ & 47.9791 & -113.5607 & CONT & Active & 51 & 1,159 & 96.9 & 0.105 & 0.009 & -0.119 \\
\hline \multicolumn{13}{|c|}{ Streamgages with significant influence } \\
\hline 9 & 05014500 & $\begin{array}{l}\text { Swiftcurrent Creek } \\
\text { at Many Glacier, } \\
\text { Montana }\end{array}$ & 48.7988 & -113.6567 & CONT & Active & 104 & 31.2 & 31.3 & 0.181 & 0.117 & 0.032 \\
\hline 272 & 06133500 & $\begin{array}{l}\text { North Fork Milk River } \\
\text { above St. Mary Canal, } \\
\text { near Browning, } \\
\text { Montana }\end{array}$ & 48.9708 & -113.0560 & CONT & Active & 77 & 60.8 & 37.5 & -0.234 & -0.189 & -0.168 \\
\hline 705 & ${ }^{2} 12357300$ & $\begin{array}{l}\text { Moccasin Creek } \\
\text { near West Glacier, } \\
\text { Montana }\end{array}$ & 48.4811 & -113.8479 & CSG & Discontinued & 17 & 2.43 & 3.1 & 0.363 & 0.409 & 0.465 \\
\hline 708 & ${ }^{2} 12358500$ & $\begin{array}{l}\text { Middle Fork Flathead } \\
\text { River near West } \\
\text { Glacier, Montana }\end{array}$ & 48.4955 & -114.0102 & CONT & Active & 78 & 1,125 & 93.8 & 0.198 & 0.177 & 0.191 \\
\hline
\end{tabular}

${ }^{1}$ The nonexceedance percentile for the basin or climatic variable value was calculated in relation to the values for all streamgages included in the regional regression analyses for the indicated hydrologic region.

${ }^{2}$ Streamgages having both significant leverage and significant influence. 
Table 15. Information on discontinued streamgages in the Northwest hydrologic region that might be candidates for reactivation to improve the streamgage network.

[NAD 83, North American Datum of 1983; $n$, total number of years of peak-flow records; CONTDA, contributing drainage area, in square miles; CONT, continuous streamgage; CSG, crest-stage gage]

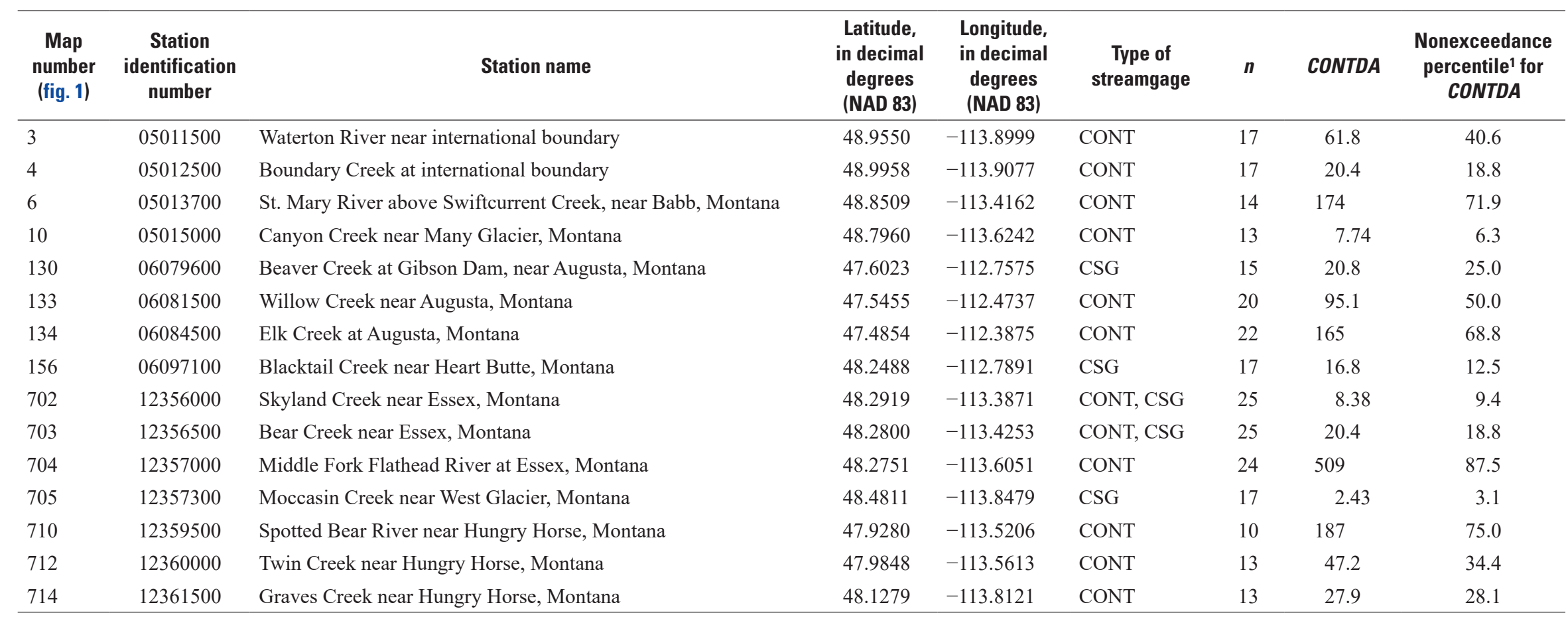

'The nonexceedance percentile for the basin or climatic variable value was calculated in relation to the values for all streamgages included in the regional regression analyses for the indicated hydrologic region. 
however, substantial proportions of annual peak flows also are in February, April-May, and July. Generally small accumulated snowpacks, variability in the timing and magnitude of low-elevation snowmelt runoff, and variability in spring and summer rainfall might contribute to greater peak-flow variability in the Northwest Foothills hydrologic region than for Montana as a whole.

About 22 percent of the streamgages in the Northwest Foothills hydrologic region are considered to have mixedpopulation characteristics (table 1) that result in a small number of unusually large peak flows that are substantially larger than the main body of peak flows. Typically, the unusually large peak-flow events result from extremely intense rainfall events in May and June. Mixed-population peak-flow datasets often are in streamgages with headwaters on or near the Continental Divide, which applies to some of the streamgages with larger drainage areas in the Northwest Foothills hydrologic region. For some streamgages in the Northwest Foothills hydrologic region, unusual rapid snowmelt events during winter, sometimes in association with rainfall, can contribute to the mixed-population peak-flow datasets. All of the mixed-population streamgages in the Northwest Foothills hydrologic region that were included in the regional regression analysis (Sando, R., and others, 2018) had positive residuals for the 1-percent AEP regression; however, none of those mixed-population streamgages had significant influence. Among the candidate explanatory variables included in the regional regression analyses, there are no variables that represent spatial variability in precipitation intensity (such as indices of the 100-year 24-hour precipitation; for example, U.S. Weather Bureau, 1961). Inclusion of variables that represent spatial variability in precipitation intensity might help address some mixed-population issues and improve potential future regional regression analyses in the Northwest Foothills hydrologic region.

The CDFs of selected basin characteristics (drainage area, mean basin elevation, and mean annual precipitation) for the road and stream intersections and for the streamgages in the Northwest Foothills hydrologic region are shown in figure 14. With respect to drainage area, the CDF of road and stream intersections for the Northwest Foothills hydrologic region generally is similar to the CDF of road and stream intersections for all of Montana (fig. 14A). In the Northwest Foothills hydrologic region, the $\mathrm{CDF}$ of streamgages diverges from the CDF of road and stream intersections in the range of drainage areas less than about $225 \mathrm{mi}^{2}$, indicating underrepresentation in that range. But, for drainage areas less than about $30 \mathrm{mi}^{2}$, the Northwest Foothills streamgage CDF indicates greater representation than for the Montana streamgage CDF. Thus, the strongest underrepresentation in the Northwest Foothills hydrologic region might be in the range of drainage areas from about 30 to $225 \mathrm{mi}^{2}$.

The Northwest Foothills hydrologic region generally is lower in elevation than Montana as a whole. Mean basin elevation for road and stream intersections in the Northwest Foothills hydrologic region ranges from 2,780 to $6,401 \mathrm{ft}$
(Dutton and others, 2021) with a median of 3,735 ft (table 4). The range for the Northwest Foothills hydrologic region is smaller than for all of Montana (1,951-9,974 ft; Dutton and others, 2021) and the median for the Northwest Foothills hydrologic region is less than for all of Montana $(4,173 \mathrm{ft}$; table 4). There are substantial differences between the CDFs of road and stream intersections for the Northwest Foothills hydrologic region relative to the CDFs of road and stream intersections for all of Montana (fig. 14B). In the Northwest Foothills hydrologic region, the CDF of streamgages diverges from the CDF of road and stream intersections in the range of mean basin elevations from about 4,000 to $4,600 \mathrm{ft}$, indicating underrepresentation in that range.

The Northwest Foothills hydrologic region generally is drier than Montana as a whole. Mean annual precipitation for road and stream intersections in the Northwest Foothills hydrologic region ranges from 9.9 to 31.2 inches (Dutton and others, 2021) with a median of 13.0 inches (table 5). The range for the Northwest Foothills hydrologic region is smaller than for all of Montana (8.4-91.3 inches; Dutton and others, 2021) and the median for the Northwest Foothills hydrologic region is somewhat smaller than for all of Montana (15.7 inches; table 5). There are substantial differences between the CDFs of road and stream intersections for the Northwest Foothills hydrologic region relative to the CDFs of road and stream intersections for all of Montana (fig. 14C). In the Northwest Foothills hydrologic region, the CDF of streamgages diverges from the $\mathrm{CDF}$ of road and stream intersections in the range of mean annual precipitation from about 14 to 18 inches, indicating underrepresentation in that range.

The explanatory variables for the Northwest Foothills hydrologic region RREs are CONTDA and PRECIP (table 6). The 1-percent AEP RRE for the Northwest Foothills hydrologic region has an SEP of 65.8 percent, which is similar the area-weighted mean SEP for all hydrologic regions in Montana (63.3 percent; table 6). For the 1-percent AEP regression for the Northwest Foothills hydrologic region, 9.7 percent of the streamgages have significant leverage and 9.7 percent of the streamgages have significant influence (table 7); these percentages generally are similar to significant leverage and influence percentages (8.2 and 10.4 percent, respectively; table 7) for all of the streamgages in Montana used in the regional regression analyses.

Information on streamgages in the Northwest Foothills hydrologic region with significant leverage and influence is presented in table 16. Two of the four significant leverage streamgages have high CONTDA values (nonexceedance percentiles greater than about 83 percent) in conjunction with large PRECIP values (nonexceedance percentiles greater than about 96 percent). One streamgage has a small CONTDA value in conjunction with a small PRECIP value (nonexceedance percentile less than about 16 percent). The three streamgages with significant influence vary with respect to the residuals for the 1-percent AEP RRE; two of the streamgages have negative residuals, and one has a positive residual. The 

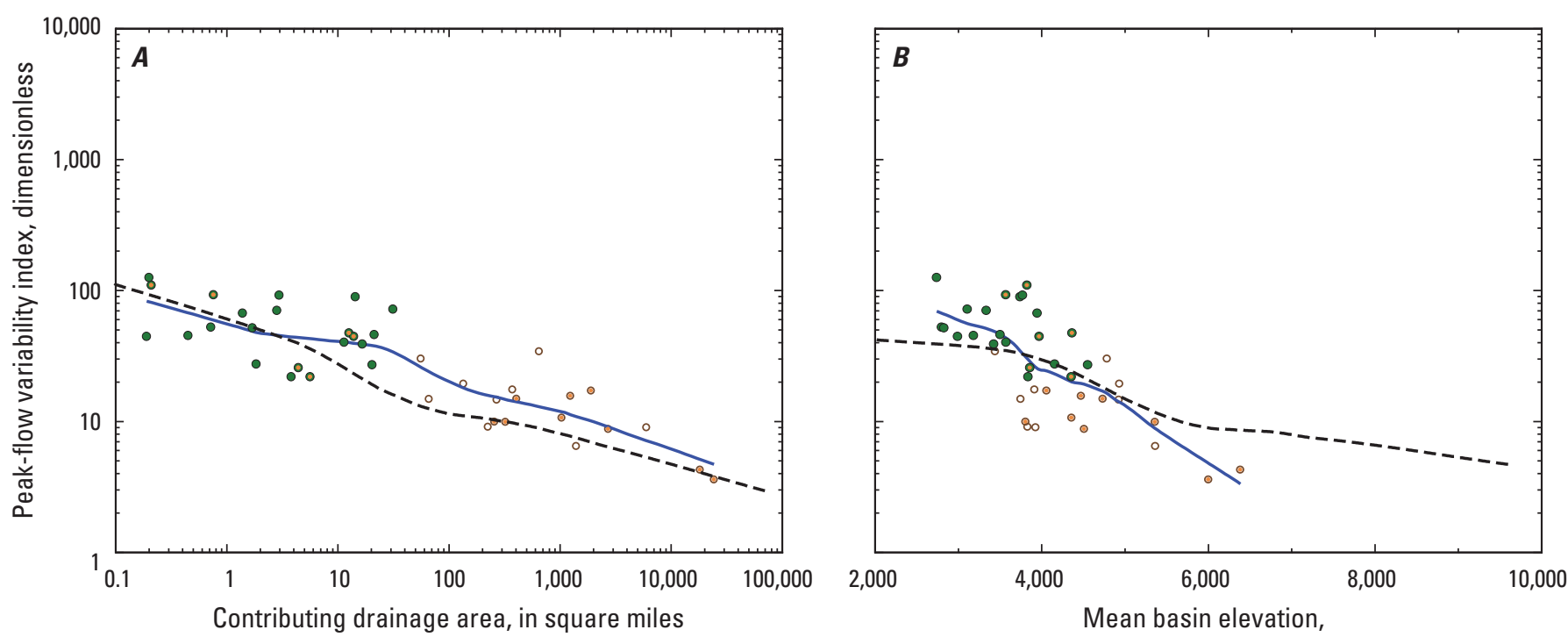

in feet above the North American Vertical Datum of 1988
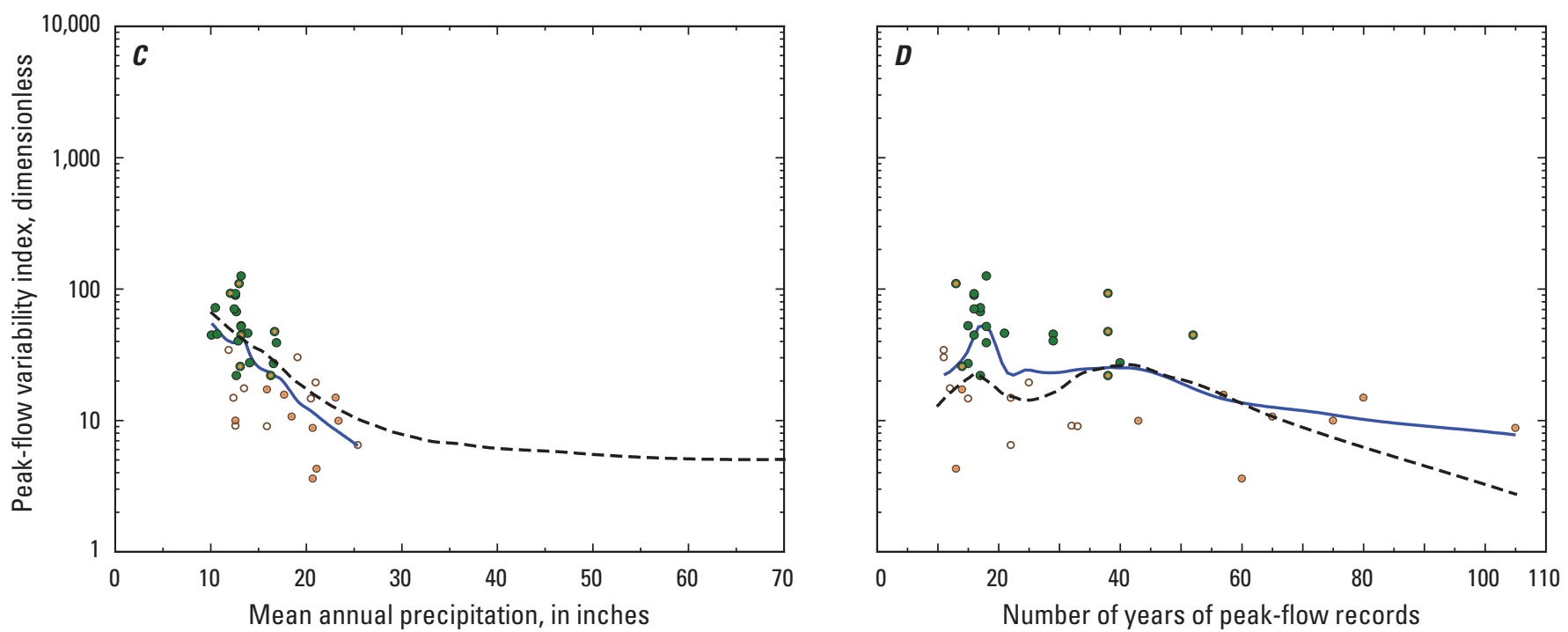

\section{EXPLANATION}

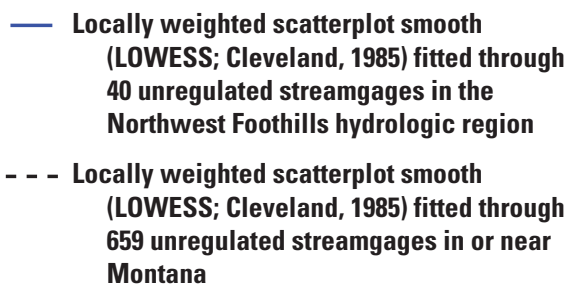

- Crest-stage streamgage

- Continuous streamgage

- Interior dot denotes active streamgage in water year 2017

Figure 12. Relations between peak-flow variability index and contributing drainage area, mean basin elevation, mean annual precipitation, and years of peak-flow records for 40 unregulated streamgages in the Northwest Foothills hydrologic region. $A$, Peak-flow variability and contributing drainage area relations. $B$, Peak-flow variability and mean basin elevation relations. $C$, Peak-flow variability and mean annual precipitation relations. $D$, Peak-flow variability and years of peak-flow records relations. 


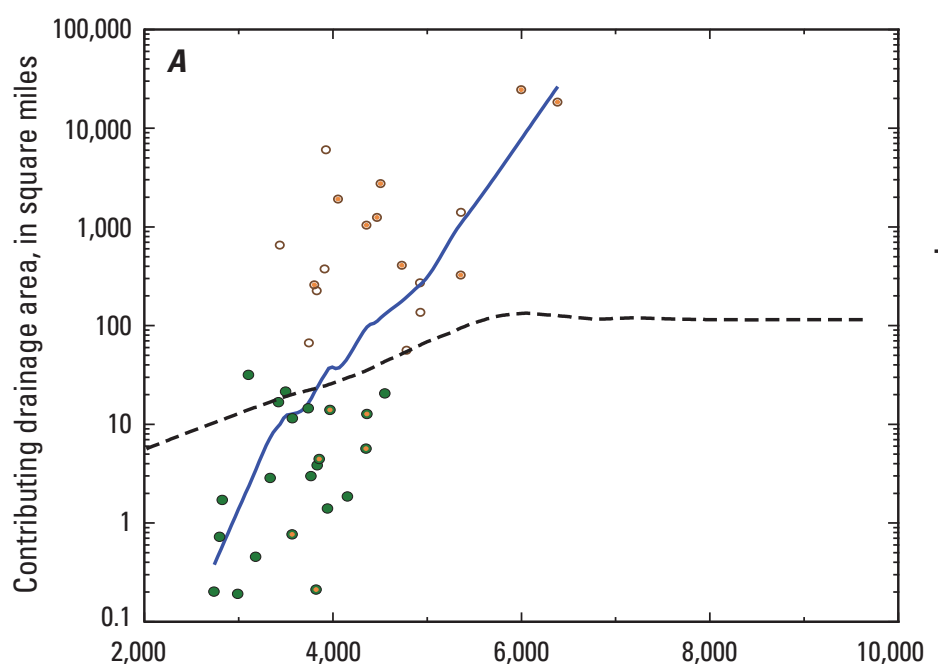

\section{EXPLANATION}

Locally weighted scatterplot smooth (LOWESS; Cleveland, 1985) fitted through 40 unregulated streamgages in the Northwest Foothills hydrologic region

- - - Locally weighted scatterplot smooth (LOWESS; Cleveland, 1985) fitted through 659 unregulated streamgages in or near Montana

- Crest-stage streamgage

- Continuous streamgage

- Interior dot denotes active streamgage in water year 2017

Mean basin elevation, in feet above the North American Vertical Datum of 1988
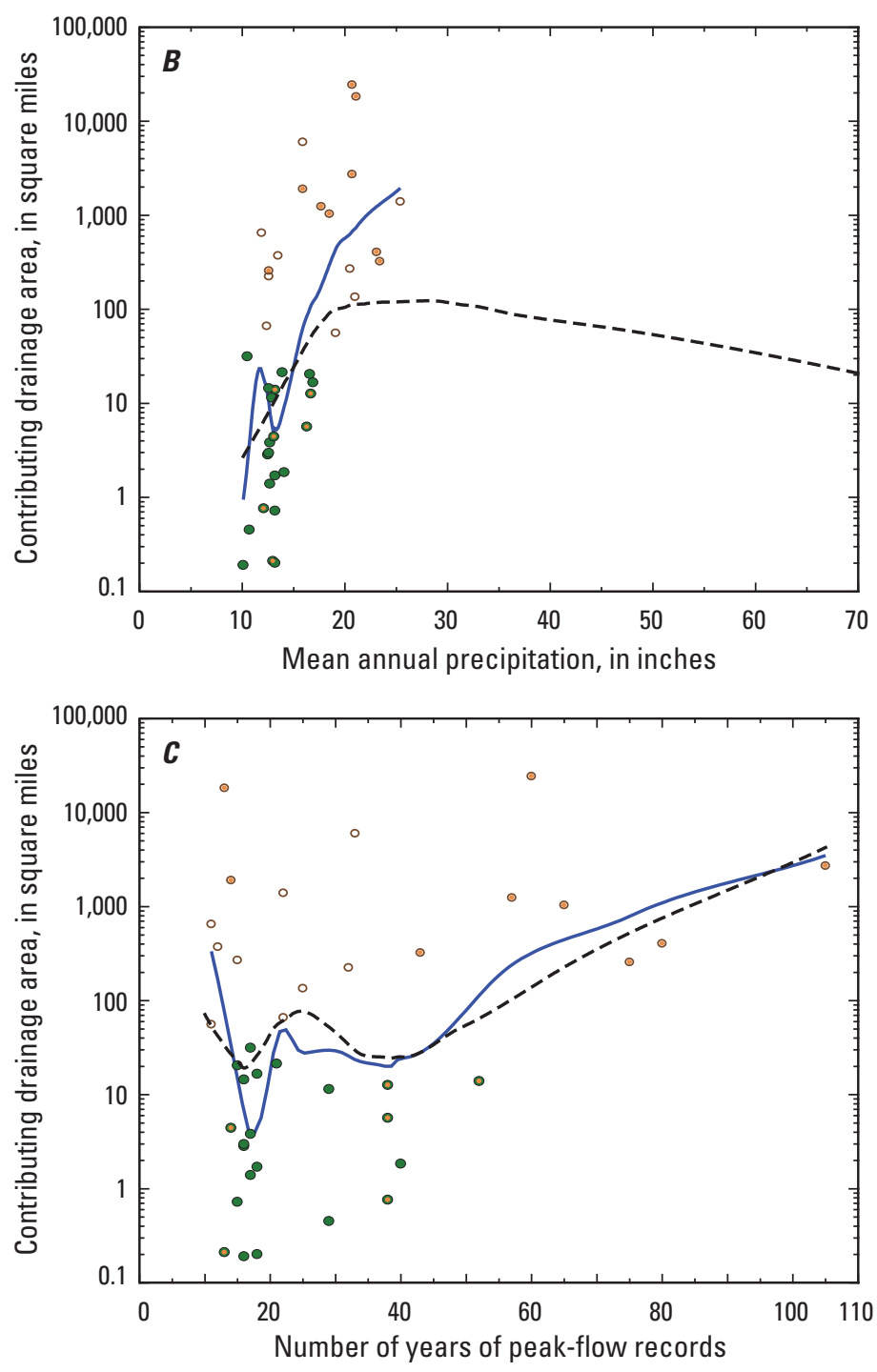

Figure 13. Relations between contributing drainage area and mean basin elevation, mean annual precipitation, and years of peak-flow records for 40 unregulated streamgages in the Northwest Foothills hydrologic region. $A$, Contributing drainage area and mean basin elevation relations. $B$, Contributing drainage area and mean annual precipitation relations. $C$, Contributing drainage area and years of peak-flow records relations. 


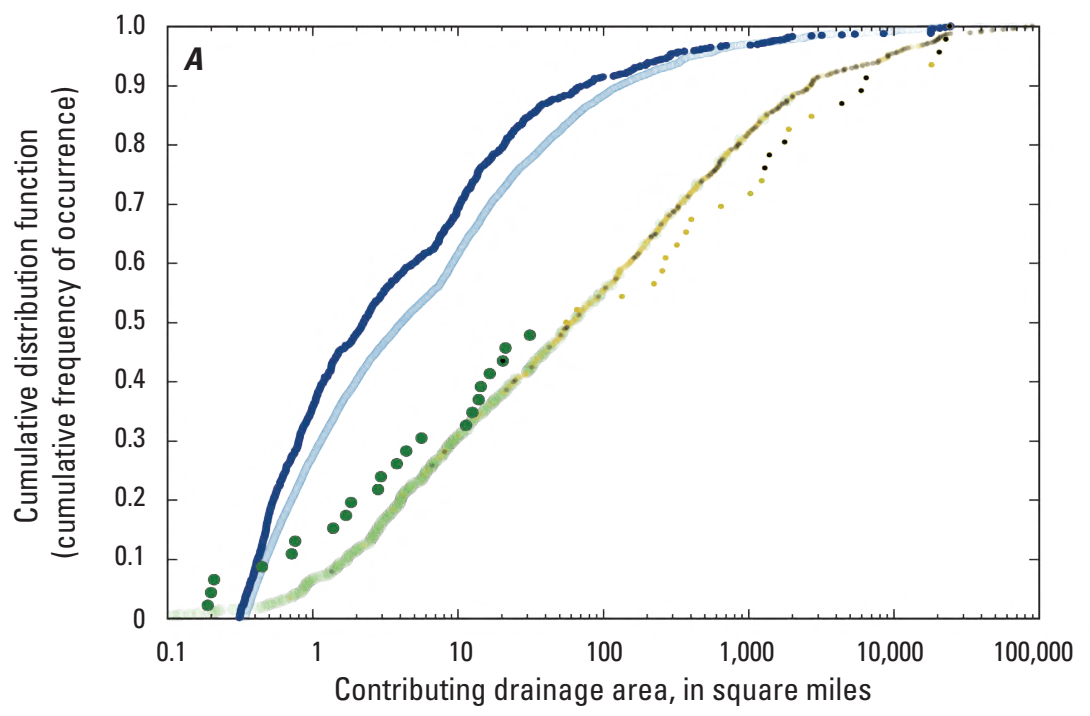

\section{EXPLANATION}

- Road and stream intersection in the Northwest Foothills hydrologic region

One of 12,639 road and stream intersections in Montana, as shown in figure 5-0pen symbols appear as solid symbols because of the high data density

Regulated and unregulated streamgages in the Northwest Foothills hydrologic region

- Crest-stage streamgage

Unregulated continuous streamgage

- Regulated continuous streamgage

Regulated and unregulated streamgages in or near Montana, as shown in figure 5

Crest-stage streamgage in or near Montana Unregulated streamgages in or near Montana

Regulated streamgages in or near Montana

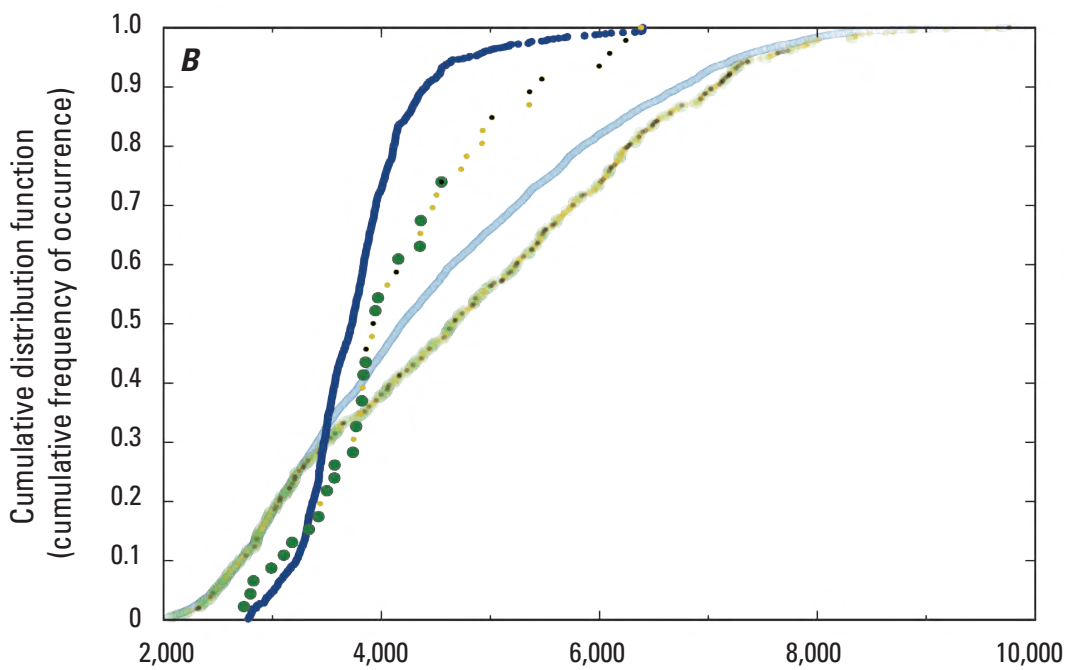

Mean basin elevation, in feet above the North American Vertical Datum of 1988

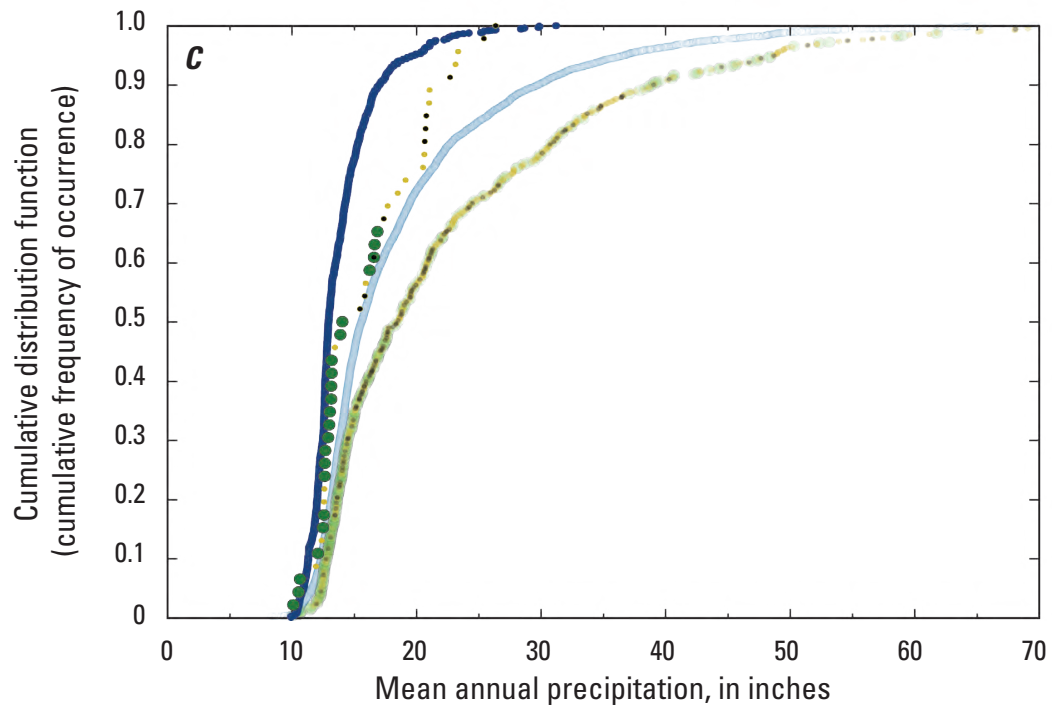

Figure 14. Cumulative distribution functions of selected drainage-basin characteristics for 1,043 road and stream intersections and for 46 streamgages (regulated and unregulated) in the Northwest Foothills hydrologic region. $A$, Contributing drainage area relations. $B$, Mean basin elevation relations. $C$, Mean annual precipitation relations. 
streamgage with both significant leverage and significant influence has a small drainage area, low precipitation, and a negative residual.

In general, the streamgage network in the Northwest Foothills hydrologic region is considered to provide generally reasonable representation of the hydroclimatic settings of that hydrologic region. The RREs of the Northwest Foothills hydrologic region are considered to be reasonably reliable. Possible shortcomings of the streamgage network in the Northwest Foothills hydrologic region include possible underrepresentation of basins with drainage area from about 30 to $225 \mathrm{mi}^{2}$, mean elevation from about 4,000 to 4,600 ft, and (or) mean annual precipitation from about 14 to 18 inches. Future improvements to the streamgage network in the Northwest Foothills hydrologic region might include establishing new CSGs or reactivating discontinued streamgages as CSGs on drainage basins with the specified characteristics. Information on discontinued streamgages in the Northwest Foothills hydrologic region that might be candidates for reactivation to improve the streamgage network is presented in table 17.

\section{Peak-Flow Variability, Peak-Flow Informational Needs, and Consideration of Regional Regression Analyses in the Northeast Plains Hydrologic Region}

The Northeast Plains hydrologic region has an area of $22,059 \mathrm{mi}^{2}$ (table 1), which ranks third largest among the eight hydrologic regions. Level III ecoregions (table 2) represented in the Northeast Plains hydrologic region include the Middle Rockies (2.2 percent), Northwestern Glaciated Plains (81.2 percent), and Northwestern Great Plains (16.6 percent). The 1,470 road and stream intersections in the Northeast Plains hydrologic region (tables 4 and 5) represent a density of 0.067 road and stream intersection per $\mathrm{mi}^{2}$, which ranks sixth among the hydrologic regions. The 88 streamgages (both regulated and unregulated; tables 4 and 5) represent an areal density of 0.00399 streamgage per $\mathrm{mi}^{2}$ (ranking eighth among hydrologic regions) and a density of 0.05986 streamgage per road and stream intersection (ranking third among hydrologic regions).

Relations between PFVI and contributing drainage area, mean basin elevation, mean annual precipitation, and years of peak-flow records for 76 unregulated streamgages in the Northeast Plains hydrologic region (table 3) are presented in figure 15 . For the 76 unregulated streamgages, PFVI generally monotonically decreases with increasing drainage area (fig. 15A) with generally small and consistent variability about the LOWESS line. Intuitively, highly variable small-scale hydroclimatic processes are integrated with increasing drainage area such that variability in many hydrologic characteristics is reduced. For the relation between PFVI and drainage area (fig. 15A), the LOWESS line for the Northeast Plains hydrologic region is consistently above the LOWESS line for all unregulated streamgages in Montana. For streamgages in the Northeast Plains hydrologic region, mean basin elevation and mean annual precipitation are within small ranges, and it is difficult to discern clear patterns in the relations between PFVI and those variables (figs. $15 B$ and 15C); however, within the small ranges, the LOWESS lines for the Northeast Plains region generally are similar to the LOWESS lines for all unregulated streamgages in Montana. The relation between PFVI and years of peak-flow records for the Northeast Plains hydrologic region generally is similar to the relation for all unregulated streamgages in Montana, but the LOWESS line for the Northeast Plains hydrologic region is consistently above the LOWESS line for all unregulated streamgages in Montana (fig. 15D).

Relations between contributing drainage area and mean basin elevation, mean annual precipitation, and years of peakflow records for the unregulated streamgages are presented in figure 16. In the various relations, the LOWESS lines for the Northeast Plains hydrologic region generally are similar to the LOWESS lines for all unregulated streamgages in Montana.

The median PFVI value for streamgages in the Northeast Plains hydrologic region (32.05, table 3 ) is substantially larger than the median for all unregulated streamgages in Montana (18.26, table 3) and ranks as the third largest median PFVI among the eight hydrologic regions. For unregulated streamgages in the Northeast Plains hydrologic region, fall and winter (October-February) precipitation accounts for about 18.7 percent of annual precipitation (table 8), which ranks sixth largest among the eight hydrologic regions. MayJune precipitation accounts for about 37.1 percent of annual precipitation (table 8), which ranks first among the hydrologic regions, and July-August precipitation accounts for 23.5 percent of annual precipitation, which ranks second among the eight hydrologic regions. In the Northeast Plains hydrologic region, annual peak flows are most frequently in March (fig. 2 of Sando, R., and others, 2018), probably resulting from lowelevation snowmelt runoff; however, substantial proportions of annual peak flows also are in April-July. Generally small accumulated snowpacks, variability in the timing and magnitude of low-elevation snowmelt runoff, and variability in spring and summer rainfall might contribute to greater peakflow variability in the Northeast Plains hydrologic region than for Montana as a whole.

About 1.4 percent of the streamgages in the Northeast Plains hydrologic region are considered to have mixedpopulation characteristics (table 1) that result in a small number of unusually large peak flows that are substantially larger than the main body of peak flows. Mixed-population peak-flow datasets are not a substantial consideration in the Northeast Plains hydrologic region.

The CDFs of selected basin characteristics (drainage area, mean basin elevation, and mean annual precipitation) for the road and stream intersections and for the streamgages in the Northeast Plains hydrologic region are shown in figure 17. With respect to drainage area, the CDF of road and stream intersections for the Northeast Plains hydrologic region is similar to the CDF of road and stream intersections for all 
Table 16. Information on streamgages in the Northwest Foothills hydrologic region with significant leverage and influence in the Montana regional regression analyses (Sando, R., and others, 2018).

[ID, identification; NAD 83, North American Datum of 1983; n, total number of years of peak-flow records; CONTDA, contributing drainage area, in square miles; PRECIP, mean annual precipitation, in inches; AEP, annual exceedance probability; CONT, continuous streamgage; CSG, crest-stage gage]

\begin{tabular}{|c|c|c|c|c|c|c|c|c|c|c|c|c|c|c|}
\hline \multirow{2}{*}{$\begin{array}{c}\text { Map } \\
\text { number } \\
\text { (fig. 1) }\end{array}$} & \multirow{2}{*}{$\begin{array}{c}\text { Streamgage } \\
\text { ID number }\end{array}$} & \multirow{2}{*}{$\begin{array}{l}\text { Streamgage } \\
\text { name }\end{array}$} & \multirow{2}{*}{$\begin{array}{c}\text { Latitude, } \\
\text { in decimal } \\
\text { degrees } \\
\text { (NAD 83) }\end{array}$} & \multirow{2}{*}{$\begin{array}{c}\text { Longitude, } \\
\text { in decimal } \\
\text { degrees } \\
\text { (NAD 83) }\end{array}$} & \multirow{2}{*}{$\begin{array}{c}\text { Type of } \\
\text { streamgage }\end{array}$} & \multirow{2}{*}{$\begin{array}{c}\text { Status of } \\
\text { streamgage } \\
\text { in water year } \\
2017\end{array}$} & \multirow{2}{*}{$n$} & \multirow{2}{*}{$\begin{array}{c}\text { CONTDA, } \\
\text { in square } \\
\text { miles }\end{array}$} & \multirow{2}{*}{$\begin{array}{c}\text { Non- } \\
\text { exceedance } \\
\text { percentile } \\
\text { for CONTDA }\end{array}$} & \multirow{2}{*}{ PRECIP } & \multirow{2}{*}{$\begin{array}{l}\text { Non- } \\
\text { exceedance } \\
\text { percentile }^{1} \\
\text { for PRECIP }\end{array}$} & \multicolumn{3}{|c|}{$\begin{array}{l}\text { Regression residuals for the } \\
\text { specified AEP regression analyses }\end{array}$} \\
\hline & & & & & & & & & & & & $\begin{array}{c}\text { 10-percent } \\
\text { AEP }\end{array}$ & $\begin{array}{l}\text { 4-percent } \\
\text { AEP }\end{array}$ & $\begin{array}{l}\text { 1-percent } \\
\text { AEP }\end{array}$ \\
\hline \multicolumn{15}{|c|}{ Streamgages with significant leverage } \\
\hline 113 & 06073500 & $\begin{array}{l}\text { Dearborn } \\
\text { River near } \\
\text { Craig, } \\
\text { Montana }\end{array}$ & 47.1990 & -112.0959 & CONT & Active & 48 & 322 & 83.9 & 23.4 & 100.0 & 0.143 & 0.081 & 0.015 \\
\hline 139 & 06088500 & $\begin{array}{c}\text { Muddy Creek } \\
\text { at Vaughn, } \\
\text { Montana }\end{array}$ & 47.5613 & -111.5418 & CONT & Active & 80 & 256 & 77.4 & 12.6 & 29.0 & 0.215 & 0.107 & -0.002 \\
\hline 167 & ${ }^{2} 06101520$ & $\begin{array}{c}\text { Favot Coulee } \\
\text { tributary } \\
\text { near Ledger, } \\
\text { Montana }\end{array}$ & 48.2630 & -111.7034 & CSG & Active & 43 & 0.76 & 16.1 & 12.1 & 16.1 & -0.091 & -0.189 & -0.347 \\
\hline 271 & 06133000 & $\begin{array}{l}\text { Milk River } \\
\text { at western } \\
\text { crossing of } \\
\text { international } \\
\text { boundary }\end{array}$ & 49.0075 & -112.5453 & CONT & Active & 85 & 405 & 90.3 & 23.1 & 96.8 & -0.023 & -0.056 & -0.101 \\
\hline \multicolumn{15}{|c|}{ Streamgages with significant influence } \\
\hline 145 & 06090650 & $\begin{array}{c}\text { Lake Creek } \\
\text { near Power, } \\
\text { Montana }\end{array}$ & 47.7079 & -111.4092 & CONT & Discontinued & 26 & 66.1 & 71.0 & 12.4 & 19.4 & -0.482 & -0.625 & -0.795 \\
\hline 167 & ${ }^{2} 06101520$ & $\begin{array}{c}\text { Favot Coulee } \\
\text { tributary } \\
\text { near Ledger, } \\
\text { Montana }\end{array}$ & 48.2630 & -111.7034 & CSG & Active & 43 & 0.76 & 16.1 & 12.1 & 16.1 & -0.091 & -0.189 & -0.347 \\
\hline 170 & 06101700 & $\begin{array}{l}\text { Fey Coulee } \\
\text { tribuary near } \\
\text { Chester, } \\
\text { Montana }\end{array}$ & 48.4479 & -111.0805 & CSG & Discontinued & 29 & 0.45 & 9.7 & 10.7 & 9.7 & 0.695 & 0.718 & 0.758 \\
\hline
\end{tabular}

${ }^{1}$ The nonexceedance percentile for the basin or climatic variable value was calculated in relation to the values for all streamgages included in the regional regression analyses for the indicated hydrologic region.

${ }^{2}$ Streamgages having both significant leverage and significant influence. 
Table 17. Information on discontinued streamgages in the Northwest Foothills hydrologic region that might be candidates for reactivation to improve the streamgage network.

[NAD 83, North American Datum of 1983; $n$, total number of years of peak-flow records; CONTDA, contributing drainage area, in square miles; PRECIP, mean annual precipitation, in inches; CSG, crest-stage gage; CONT, continuous streamgage]

\begin{tabular}{|c|c|c|c|c|c|c|c|c|c|c|}
\hline $\begin{array}{c}\text { Map } \\
\text { number } \\
\text { (fig. 1) }\end{array}$ & $\begin{array}{c}\text { Station } \\
\text { identification } \\
\text { number }\end{array}$ & Station name & $\begin{array}{c}\text { Latitude, } \\
\text { in decimal } \\
\text { degrees } \\
\text { (NAD 83) }\end{array}$ & $\begin{array}{c}\text { Longitude, } \\
\text { in decimal } \\
\text { degrees } \\
\text { (NAD 83) }\end{array}$ & $\begin{array}{c}\text { Type of } \\
\text { streamgage }\end{array}$ & $n$ & CONTDA & $\begin{array}{l}\text { Nonexceedance } \\
\text { percentile }{ }^{1} \text { for } \\
\text { CONTDA }\end{array}$ & PRECIP & $\begin{array}{c}\text { Nonexceedance } \\
\text { percentile }{ }^{1} \text { for } \\
\text { PRECIP }\end{array}$ \\
\hline 137 & 06087900 & $\begin{array}{l}\text { Muddy Creek tributary near Power, } \\
\text { Montana }\end{array}$ & 47.7557 & -111.7296 & CSG & 17 & 3.81 & 35.5 & 12.7 & 35.5 \\
\hline 141 & 06089300 & $\begin{array}{l}\text { Sun River tributary near Great Falls, } \\
\text { Montana }\end{array}$ & 47.5271 & -111.4019 & CSG & 21 & 21.3 & 61.3 & 13.9 & 61.3 \\
\hline 145 & 06090650 & Lake Creek near Power, Montana & 47.7079 & -111.4092 & CONT & 26 & 66.1 & 71.0 & 12.4 & 19.4 \\
\hline 147 & 06090810 & $\begin{array}{l}\text { Ninemile Coulee near Fort Benton, } \\
\text { Montana }\end{array}$ & 47.7005 & -110.7041 & CSG & 18 & 16.6 & 54.8 & 16.9 & 77.4 \\
\hline 157 & 06098000 & Dupuyer Creek near Valier, Montana & 48.2350 & -112.3982 & CONT & 25 & 135 & 74.2 & 21.0 & 93.5 \\
\hline 163 & 06100200 & $\begin{array}{l}\text { Heines Coulee tributary near Valier, } \\
\text { Montana }\end{array}$ & 48.2489 & -112.2290 & CSG & 17 & 1.39 & 19.4 & 12.7 & 38.7 \\
\hline 165 & 06100500 & $\begin{array}{l}\text { Dry Fork Marias River at Fowler, } \\
\text { Montana }\end{array}$ & 48.3157 & -111.7825 & CONT & 12 & 372 & 87.1 & 13.5 & 58.1 \\
\hline 168 & 06101560 & Pondera Coulee near Chester, Montana & 48.2705 & -111.1458 & CONT & 11 & 648 & 93.5 & 11.9 & 12.9 \\
\hline 169 & 06101600 & $\begin{array}{l}\text { Marias River tributary No. } 3 \text { near Chester, } \\
\text { Montana }\end{array}$ & 48.2310 & -110.8917 & CSG & 16 & 0.19 & 3.2 & 10.1 & 3.2 \\
\hline 171 & 06101800 & Sixmile Coulee near Chester, Montana & 48.3305 & -110.9453 & CSG & 17 & 31.4 & 64.5 & 10.5 & 6.5 \\
\hline 172 & 06101900 & $\begin{array}{l}\text { Dead Indian Coulee near Fort Benton, } \\
\text { Montana }\end{array}$ & 48.0815 & -110.8379 & CSG & 16 & 2.83 & 29.0 & 12.5 & 22.6 \\
\hline 175 & 06102100 & $\begin{array}{l}\text { Dry Fork Coulee tributary near Loma, } \\
\text { Montana }\end{array}$ & 47.9486 & -110.5441 & CSG & 15 & 0.72 & 12.9 & 13.2 & 54.8 \\
\hline 176 & 06102200 & Marias River tributary at Loma, Montana & 47.9439 & -110.5146 & CSG & 18 & 1.70 & 22.6 & 13.2 & 51.6 \\
\hline 177 & 06102300 & $\begin{array}{l}\text { Maris River tributary No. } 2 \text { at Loma, } \\
\text { Montana }\end{array}$ & 47.9413 & -110.5058 & CSG & 18 & 0.20 & 6.5 & 13.2 & 48.4 \\
\hline 181 & 06106000 & Deep Creek near Choteau, Montana & 47.7520 & -112.2395 & CONT & 15 & 269 & 80.6 & 20.5 & 90.3 \\
\hline 182 & 06107000 & $\begin{array}{l}\text { North Fork Muddy Creek near Bynum, } \\
\text { Montana }\end{array}$ & 47.9919 & -112.3574 & CONT & 11 & 55.8 & 67.7 & 19.1 & 87.1 \\
\hline 184 & 06108200 & Kinley Coulee near Dutton, Montana & 47.8428 & -111.5917 & CSG & 16 & 14.4 & 51.6 & 12.6 & 25.8 \\
\hline 185 & 06108300 & $\begin{array}{l}\text { Kinley Coulee tributary near Dutton, } \\
\text { Montana }\end{array}$ & 47.8428 & -111.5521 & CSG & 16 & 2.96 & 32.3 & 12.6 & 32.3 \\
\hline
\end{tabular}

${ }^{1}$ The nonexceedance percentile for the basin or climatic variable value was calculated in relation to the values for all streamgages included in the regional regression analyses for the indicated hydrologic region. 

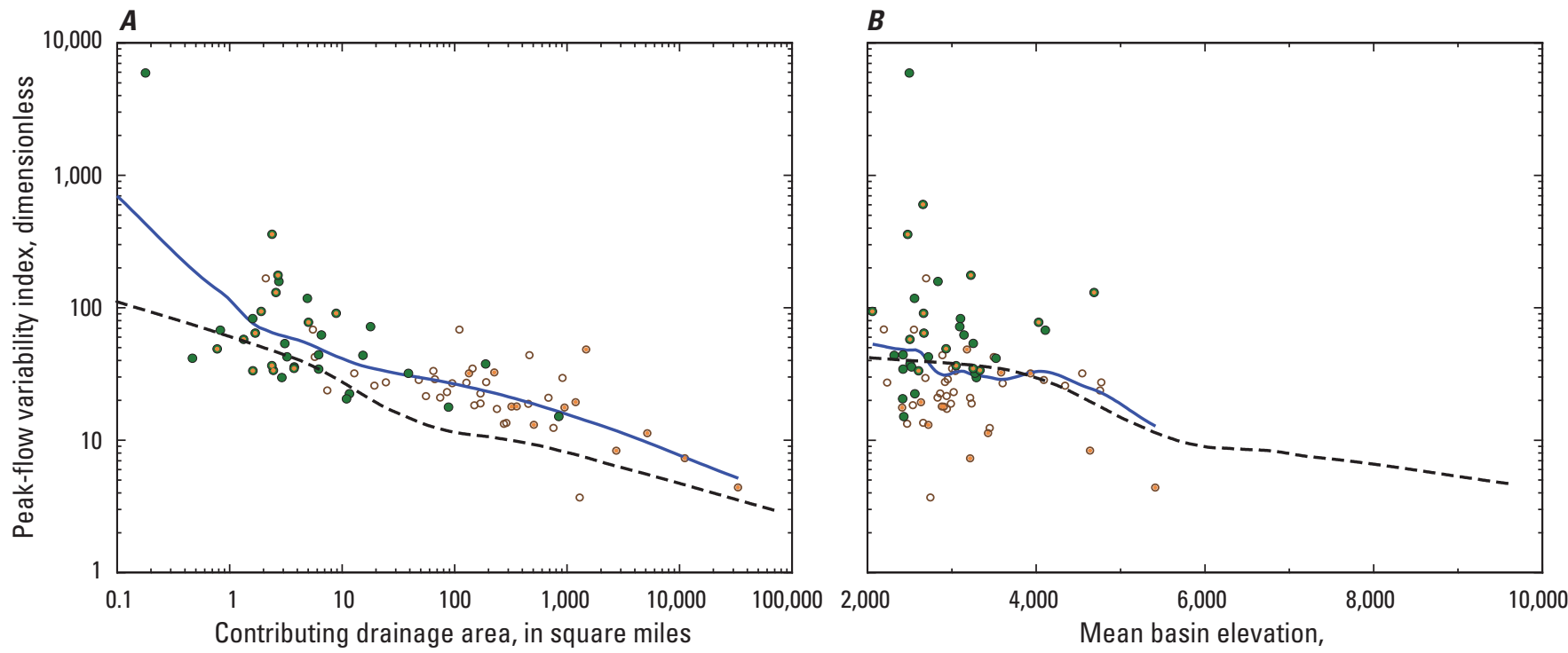

in feet above the North American Vertical Datum of 1988

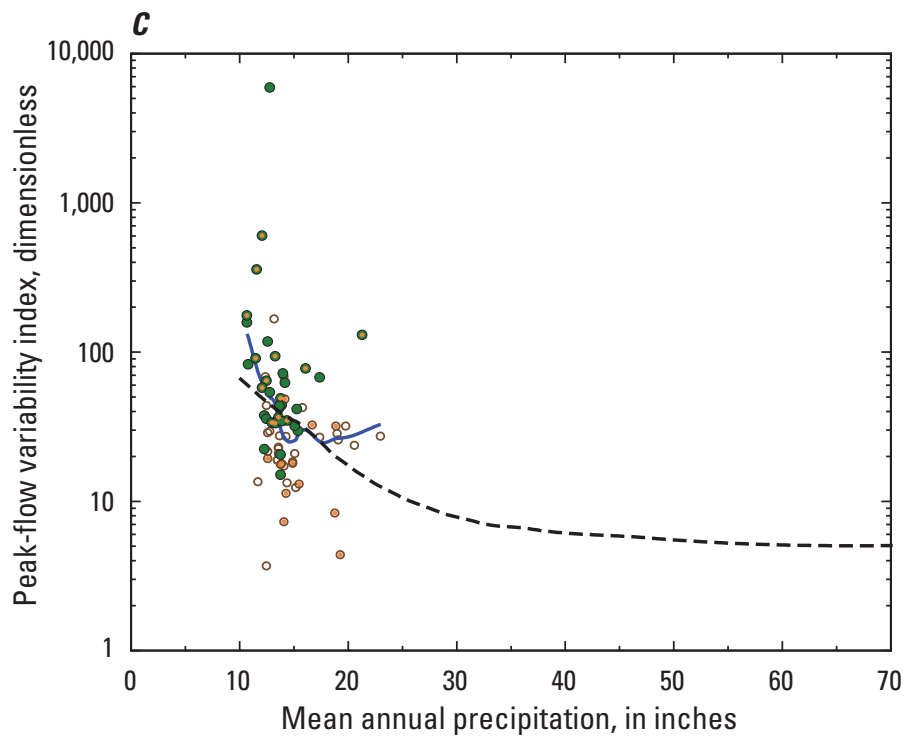

D

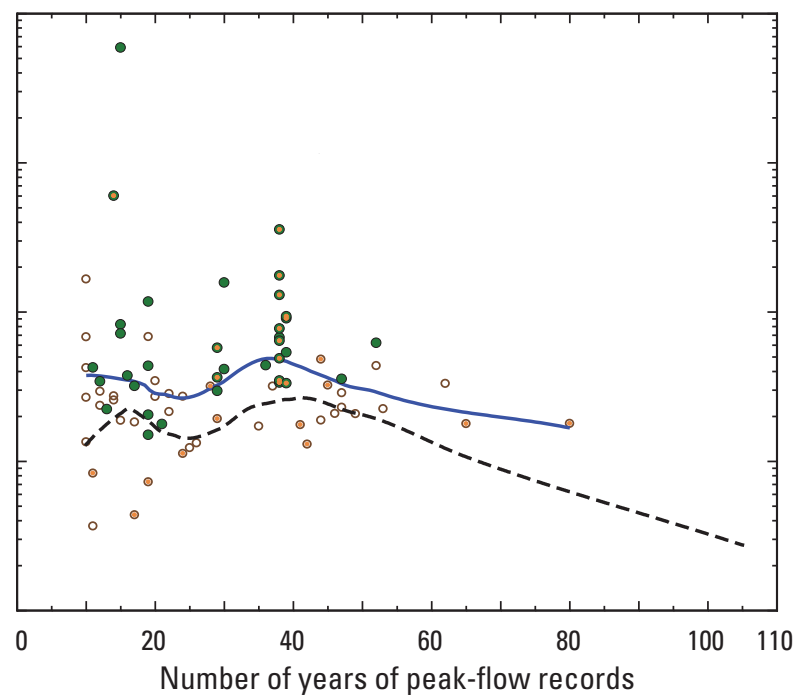

\section{EXPLANATION}

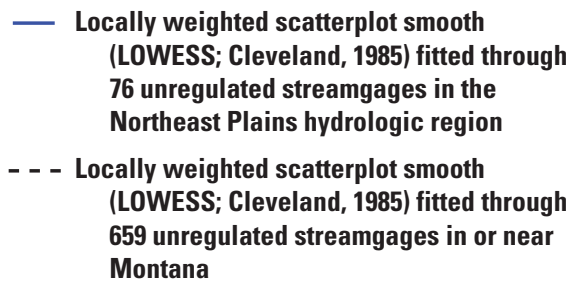

- Crest-stage streamgage

- Continuous streamgage

- Interior dot denotes active streamgage in water year 2017

Figure 15. Relations between peak-flow variability index and contributing drainage area, mean basin elevation, mean annual precipitation, and years of peak-flow records for 76 unregulated streamgages in the Northeast Plains hydrologic region. $A$, peak-flow variability and contributing drainage area relations; $B$, peak-flow variability and mean basin elevation relations; $C$, peak-flow variability and mean annual precipitation relations; $D$, peak-flow variability and years of peak-flow records relations. 
of Montana (fig. 17A). In the Northeast Plains hydrologic region, the $\mathrm{CDF}$ of streamgages diverges from the $\mathrm{CDF}$ of road and stream intersections in the range of drainage areas less than about $100 \mathrm{mi}^{2}$, indicating underrepresentation in that range, but throughout that range, the Northeast Plains streamgage CDF indicates similar representation as for the Montana streamgage CDF. Thus, with respect to drainage area, underrepresentation probably is not a substantial issue in the Northeast Plains hydrologic region.

The Northeast Plains hydrologic region generally is lower in elevation than Montana as a whole. Mean basin elevation for road and stream intersections in the Northeast Plains hydrologic region ranges from 1,984 to 6,150 ft (Dutton and others, 2021) with a median of $2,943 \mathrm{ft}$ (table 4). The range for the Northeast Plains hydrologic region is smaller than for all of Montana (1,951-9,974 ft; Dutton and others, 2021) and the median for the Northeast Plains hydrologic region is less than for all of Montana (4,173 ft; table 4). There are substantial differences between the CDFs of road and stream intersections for the Northeast Plains hydrologic region relative to the CDFs of road and stream intersections for all of Montana (fig. 17B). With respect to mean basin elevation, the pattern of the streamgage CDF reasonably represents the road and stream intersection CDF but with small overrepresentation at elevations higher than about 3,400 ft.

The Northeast Plains hydrologic region generally is drier than Montana as a whole. Mean annual precipitation for road and stream intersections in the Northeast Plains hydrologic region ranges from 10.2 to 32.3 inches (Dutton and others, 2021) with a median of 13.4 inches (table 5). The range for the Northeast Plains hydrologic region is smaller than for all of Montana (8.4-91.3 ft; Dutton and others, 2021) and the median for the Northeast Plains hydrologic region is somewhat smaller than for all of Montana (15.7 inches; table 5). There are substantial differences between the CDFs of road and stream intersections for the Northeast Plains hydrologic region relative to the CDFs of road and stream intersections for all of Montana (fig. 17C). With respect to mean annual precipitation, the pattern of the streamgage CDF reasonably represents the road and stream intersection CDF but with small overrepresentation at mean annual precipitation greater than about 20 inches.

The explanatory variables for the Northeast Plains hydrologic region RREs are CONTDA and percentage of basin above 5,000 ft elevation $\left(E L_{5000}\right.$; table 6). The 1-percent AEP RRE for the Northeast Plains hydrologic region has an SEP of 54.5 percent, which is less than the area-weighted mean SEP for all hydrologic regions in Montana (63.3 percent; table 6). For the 1-percent AEP regression for the Northeast Plains hydrologic region, 9.4 percent of the streamgages have significant leverage and 10.9 percent of the streamgages have significant influence (table 7); these percentages generally are similar to significant leverage and influence percentages (8.2 and 10.4 percent, respectively; table 7) for all of the streamgages in Montana used in the regional regression analyses.
Information on streamgages in the Northeast Plains hydrologic region with significant leverage and influence is presented in table 18. Five of the six significant leverage streamgages have high $E L_{5000}$ values (nonexceedance percentiles greater than about 94 percent) and one of the six has a low $E L_{5000}$ value (nonexceedance percentile of 1.6 percent). Five of the six streamgages with significant leverage have positive residuals for the 1-percent AEP RRE. The 10 streamgages with significant influence vary with respect to the residuals for the 1-percent AEP RRE; five of the streamgages have negative residuals, and five have positive residuals. The two streamgages with both significant leverage and significant influence have positive residuals.

In general, the streamgage network in the Northeast Plains hydrologic region is considered to provide generally reasonable representation of the hydroclimatic settings of that hydrologic region. The RREs of the Northeast Plains hydrologic region are considered to be reasonably reliable. Possible shortcomings of the streamgage network in the Northeast Plains hydrologic region include small overrepresentation of basins with mean basin elevation higher than about $3,400 \mathrm{ft}$, and (or) mean annual precipitation greater than about 20 inches. Future improvements to the streamgage network in the Northeast Plains hydrologic region might include discontinuing CSGs with the specified characteristics and (or) reactivating discontinued streamgages as CSGs on drainage basins outside of the specified characteristics. Information on discontinued streamgages in the Northeast Plains hydrologic region that might be candidates for reactivation to improve the streamgage network is presented in table 19.

\section{Peak-Flow Variability, Peak-Flow Informational Needs, and Consideration of Regional Regression Analyses in the East-Central Plains Hydrologic Region}

The East-Central Plains hydrologic region has an area of $28,451 \mathrm{mi}^{2}$ (table 1), which ranks first largest among the eight hydrologic regions. Level III ecoregions (table 2) represented in the East-Central Plains hydrologic region include the Northwestern Glaciated Plains (23.6 percent) and Northwestern Great Plains (76.4 percent). The 1,586 road and stream intersections in the East-Central Plains hydrologic region (tables 4 and 5) represent a density of 0.056 road and stream intersection per $\mathrm{mi}^{2}$, which ranks seventh among the hydrologic regions. The 114 streamgages (both regulated and unregulated; tables 4 and 5) represent an areal density of 0.00401 streamgage per $\mathrm{mi}^{2}$ (ranking seventh among hydrologic regions) and a density of 0.07188 streamgage per road and stream intersection (ranking second among hydrologic regions).

Relations between $P F V I$ and contributing drainage area, mean basin elevation, mean annual precipitation, and years of peak-flow records for 102 unregulated streamgages in the East-Central Plains hydrologic region (table 3) are presented 


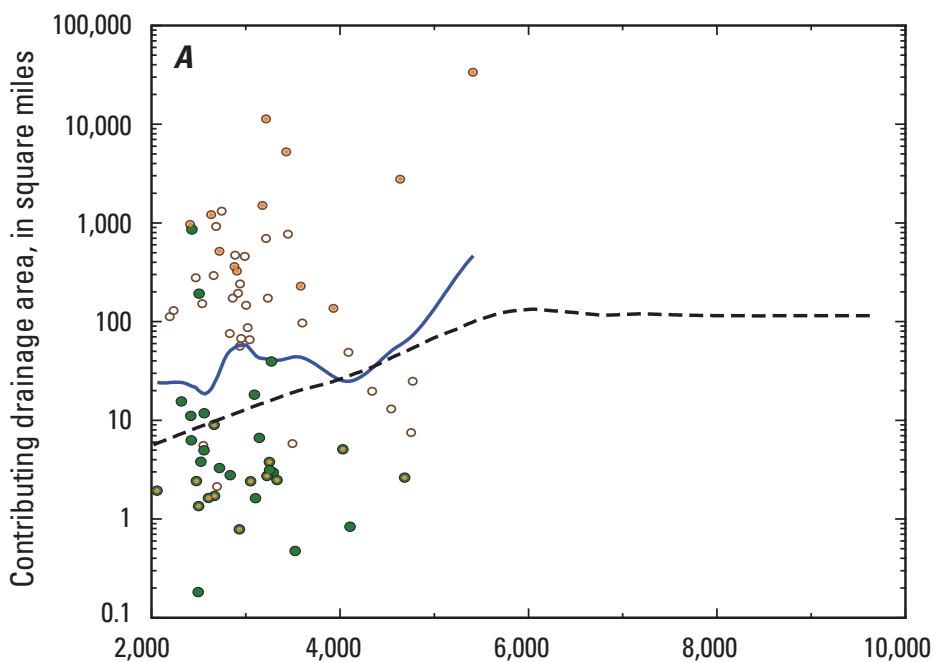

\section{EXPLANATION}

Locally weighted scatterplot smooth (LOWESS; Cleveland, 1985) fitted through 76 unregulated streamgages in the Northeast Plains hydrologic region

- - - Locally weighted scatterplot smooth (LOWESS; Cleveland, 1985) fitted through 659 unregulated streamgages in or near Montana

- Crest-stage streamgage

- Continuous streamgage

Interior dot denotes active streamgage in water year 2017

Mean basin elevation, in feet above the North American Vertical Datum of 1988
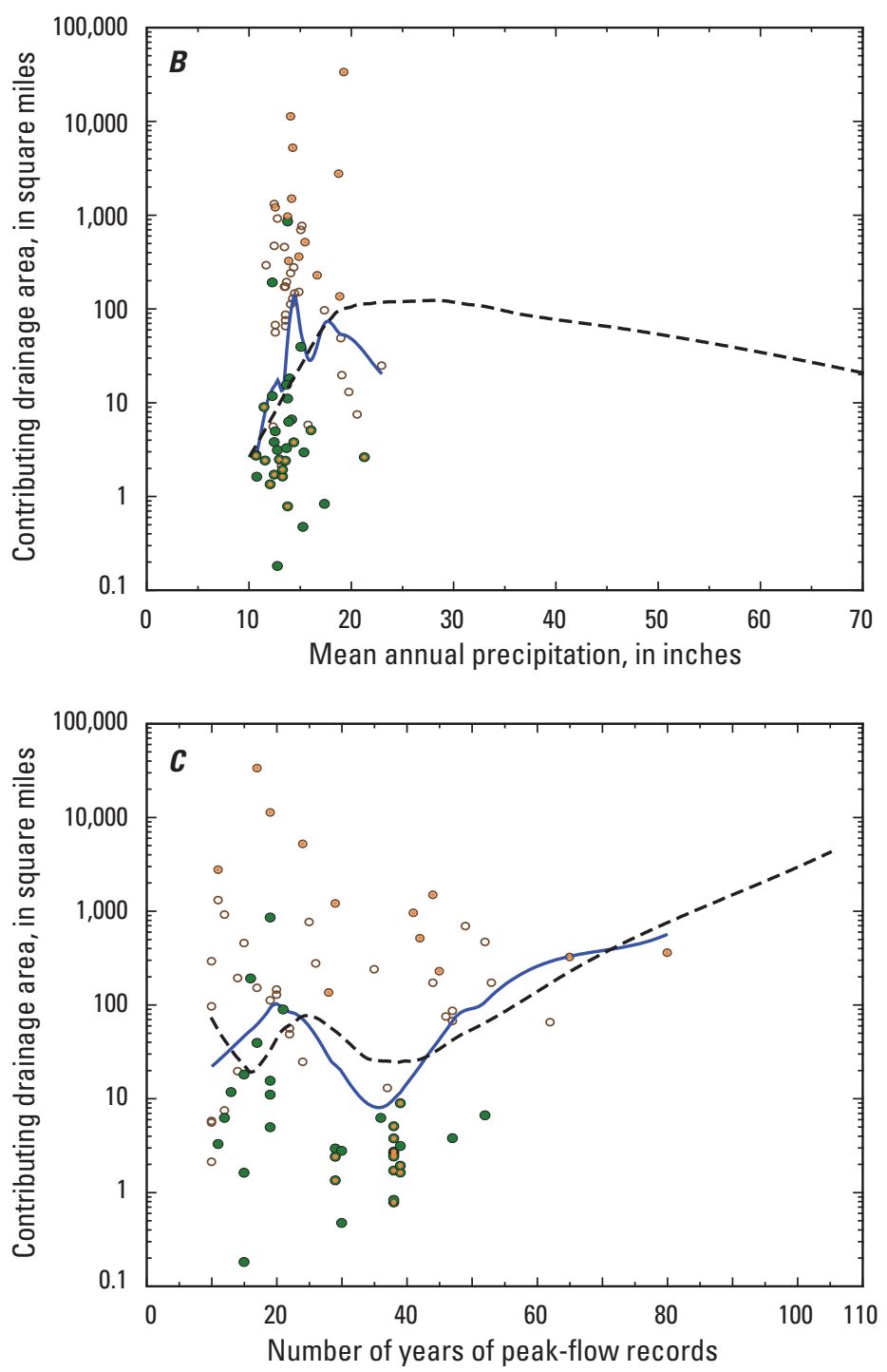

Figure 16. Relations between contributing drainage area and mean basin elevation, mean annual precipitation, and years of peak-flow records for 76 unregulated streamgages in the Northeast Plains hydrologic region. $A$, Contributing drainage area and mean basin elevation relations. $B$, Contributing drainage area and mean annual precipitation relations. $C$, Contributing drainage area and years of peak-flow records relations. 

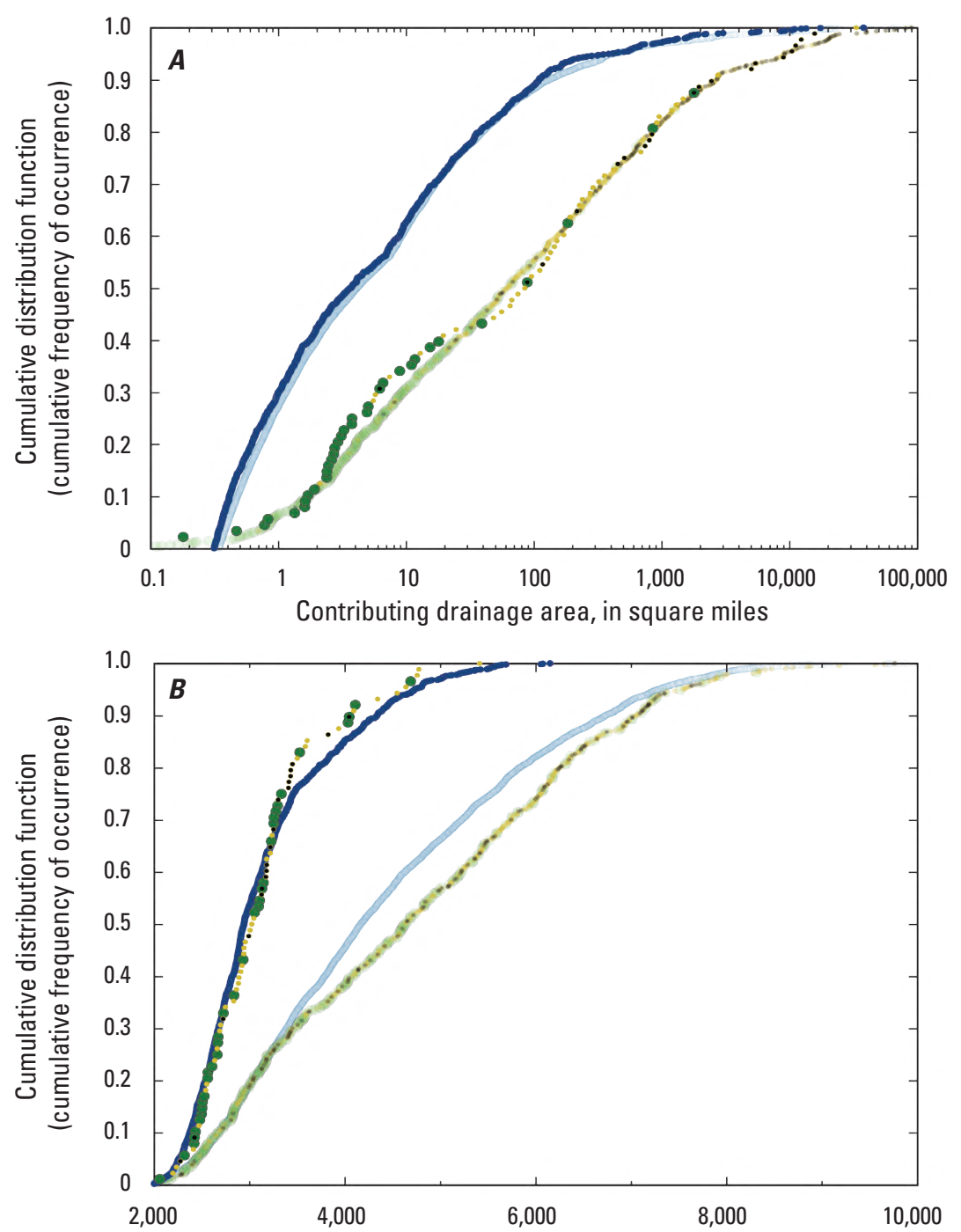

\section{EXPLANATION}

- Road and stream intersection in the Northeast Plains hydrologic region

One of 12,639 road and stream intersections in Montana, as shown in figure 5-0pen symbols appear as solid symbols because of the high data density

Regulated and unregulated streamgages in the Northeast Plains hydrologic region

- Crest-stage streamgage

- Unregulated continuous streamgage

- Regulated continuous streamgage

Regulated and unregulated streamgages in or near Montana, as shown in figure $\mathbf{5}$

Crest-stage streamgage in or near Montana Unregulated streamgages in or near Montana

- Regulated streamgages in or near Montana

Mean basin elevation, in feet above the North American Vertical Datum of 1988

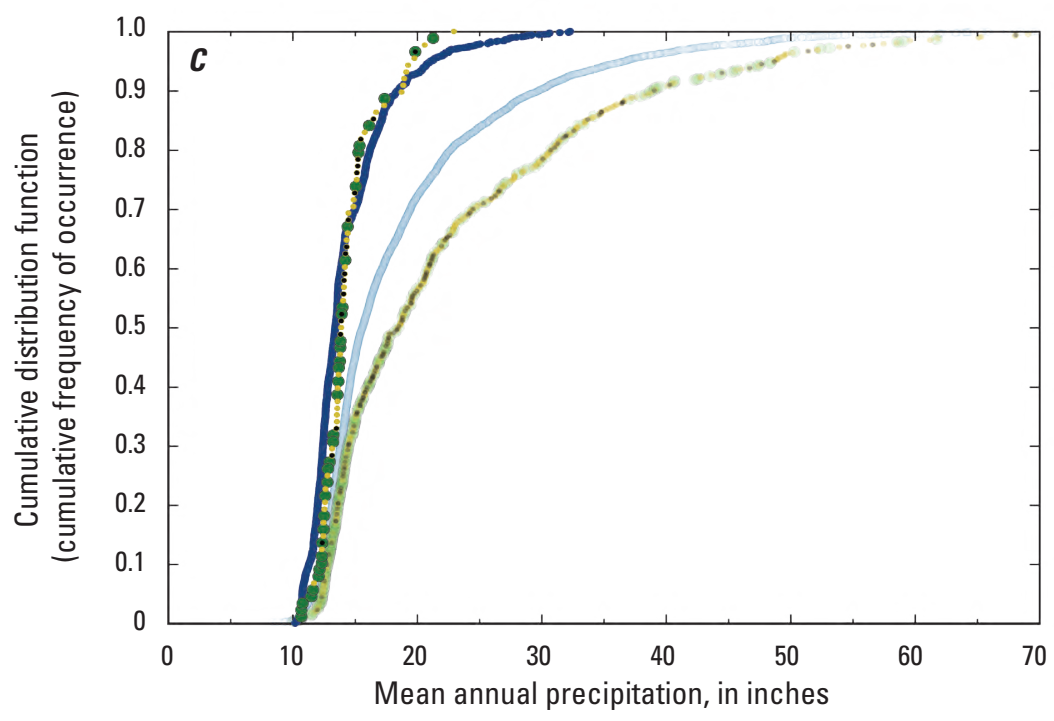

Figure 17. Cumulative distribution functions of selected drainage-basin characteristics for 1,470 road and stream intersections and for 88 streamgages (regulated and unregulated) in the Northeast Plains hydrologic region. $A$, Contributing drainage area relations. $B$, Mean basin elevation relations. $C$, Mean annual precipitation relations. 
in figure 18. For the 102 unregulated streamgages, PFVI generally monotonically decreases with increasing drainage area (fig. 18A) with generally small and consistent variability about the LOWESS line. Intuitively, highly variable small-scale hydroclimatic processes are integrated with increasing drainage area such that variability in many hydrologic characteristics is reduced. For the relation between PFVI and drainage area (fig. 18A), the LOWESS line for the East-Central Plains hydrologic region generally is above the LOWESS line for all unregulated streamgages in Montana. For streamgages in the East-Central Plains hydrologic region, mean basin elevation and mean annual precipitation generally are within small ranges, and it is difficult to discern clear patterns in the relations between $P F V I$ and those variables (figs. $18 B$ and $18 C$ ); however, within the small ranges, the LOWESS lines for the East-Central Plains region generally are similar to the LOWESS lines for all unregulated streamgages in Montana. The relation between $P F V I$ and years of peak-flow records for the East-Central Plains hydrologic region generally is similar to the relation for all unregulated streamgages in Montana, but the LOWESS line for the East-Central Plains hydrologic region is consistently above the LOWESS line for all unregulated streamgages in Montana (fig. 18D).

Relations between contributing drainage area and mean basin elevation, mean annual precipitation, and years of peakflow records for the unregulated streamgages are presented in figure 19. In the relations between contributing drainage area and mean basin elevation and mean annual precipitation (figs. $19 A$ and 19B), the small ranges in mean basin elevation and mean annual precipitation in the East-Central Plains hydrologic region make it difficult to discern clear patterns in the relations. In the relation between contributing drainage area and years of peak-flow records (fig. 19C), the LOWESS line for the East-Central Plains hydrologic region generally is below the LOWESS line for all unregulated streamgages in Montana, indicating that streamgages on small basins generally have longer periods of record in the East-Central Plains hydrologic region than in Montana as a whole.

The median PFVI value for streamgages in the EastCentral Plains hydrologic region (36.00, table 3$)$ is substantially larger than the median for all unregulated streamgages in Montana (18.26, table 3) and ranks as the first largest median PFVI among the eight hydrologic regions. For unregulated streamgages in the East-Central Plains hydrologic region, fall and winter (October-February) precipitation accounts for about 17.7 percent of annual precipitation (table 8), which ranks seventh largest among the eight hydrologic regions. May-June precipitation accounts for about 36.4 percent of annual precipitation (table 8), which ranks third among the hydrologic regions, and July-August precipitation accounts for 23.9 percent of annual precipitation, which ranks first among the eight hydrologic regions. In the East-Central Plains hydrologic region, annual peak flows are most frequently in March and June (fig. 2 of Sando, R., and others, 2018), probably resulting from low-elevation snowmelt runoff and springtime rainfall runoff, respectively; however, substantial proportions of annual peak flows also are in February, AprilMay, and July. Generally small accumulated snowpacks, variability in the timing and magnitude of low-elevation snowmelt runoff, and variability in spring and summer rainfall might contribute to greater peak-flow variability in the East-Central Plains hydrologic region than for Montana as a whole.

About 2.2 percent of the streamgages in the East-Central Plains hydrologic region are considered to have mixedpopulation characteristics (table 1) that result in a small number of unusually large peak flows that are substantially larger than the main body of peak flows. Mixed-population peak-flow datasets are not a substantial consideration in the East-Central Plains hydrologic region.

The CDFs of selected basin characteristics (drainage area, mean basin elevation, and mean annual precipitation) for the road and stream intersections and for the streamgages in the East-Central Plains hydrologic region are shown in figure 20. With respect to drainage area, the CDF of road and stream intersections for the East-Central Plains hydrologic region is similar to the CDF of road and stream intersections for all of Montana (fig. 20A). In the East-Central Plains hydrologic region, the CDF of streamgages diverges from and is substantially above the CDF of streamgages for Montana as a whole in the range of drainage areas less than about $17 \mathrm{mi}^{2}$, indicating that small basins are more strongly represented in the EastCentral Plains hydrologic region. It is noteworthy that about 58 percent of the streamgages (both regulated and unregulated) in the East-Central Plains hydrologic region are on basins with drainage areas less than about $17 \mathrm{mi}^{2}$, whereas the other 42 percent of the streamgages are distributed over a large range in drainage areas from about 17 to several thousand square miles. In the East-Central Plains hydrologic region, the CDF of streamgages diverges from the CDF of road and stream intersections in the range of drainage areas from about 17 to $220 \mathrm{mi}^{2}$, indicating underrepresentation in that range.

The East-Central Plains hydrologic region generally is lower in elevation than Montana as a whole. Mean basin elevation for road and stream intersections in the East-Central Plains hydrologic region ranges from 1,951 to 6,385 ft (Dutton and others, 2021) with a median of $2,838 \mathrm{ft}$ (table 4). The range for the East-Central Plains hydrologic region is smaller than for all of Montana (1,951-9,974 ft; Dutton and others, 2021) and the median for the East-Central Plains hydrologic region is less than for all of Montana (4,173 ft; table 4). There are substantial differences between the CDFs of road and stream intersections for the East-Central Plains hydrologic region relative to the CDFs of road and stream intersections for all of Montana (fig. 20B). With respect to mean basin elevation, the pattern of the streamgage CDF reasonably represents the road and stream intersection CDF but with small underrepresentation in a small range of elevations from about 3,600 to $4,000 \mathrm{ft}$.

The East-Central Plains hydrologic region generally is drier than Montana as a whole. Mean annual precipitation for road and stream intersections in the East-Central Plains hydrologic region ranges from 11.1 to 24.1 inches (Dutton 
Table 18. Information on streamgages in the Northeast Plains hydrologic region with significant leverage and influence in the Montana regional regression analyses (Sando, $R$., and others, 2018).

[ID, identification; NAD 83, North American Datum of $1983 ; n$, total number of years of peak-flow records; $C O N T D A$, contributing drainage area, in square miles; $E L_{5000}$, percentage of basin above 5,000 feet elevation; AEP, annual exceedance probability; CONT, continuous streamgage; CSG, crest-stage gage]

\begin{tabular}{|c|c|c|c|c|c|c|c|c|c|c|c|c|c|c|}
\hline \multirow{2}{*}{$\begin{array}{c}\text { Map } \\
\text { number } \\
\text { (fig. 1) }\end{array}$} & \multirow{2}{*}{$\begin{array}{l}\text { Streamgage } \\
\text { ID number }\end{array}$} & \multirow{2}{*}{$\begin{array}{l}\text { Streamgage } \\
\text { name }\end{array}$} & \multirow{2}{*}{$\begin{array}{c}\text { Latitude, } \\
\text { in decimal } \\
\text { degrees } \\
\text { (NAD 83) }\end{array}$} & \multirow{2}{*}{$\begin{array}{c}\text { Longitude, } \\
\text { in decimal } \\
\text { degrees } \\
\text { (NAD 83) }\end{array}$} & \multirow{2}{*}{$\begin{array}{c}\text { Type of } \\
\text { streamgage }\end{array}$} & \multirow{2}{*}{$\begin{array}{c}\text { Status of } \\
\text { streamgage } \\
\text { in water } \\
\text { year } 2017\end{array}$} & \multirow{2}{*}{$n$} & \multirow{2}{*}{ CONTDA } & \multirow{2}{*}{$\begin{array}{l}\text { Non- } \\
\text { exceedance } \\
\text { percentile } \\
\text { for CONTDA }\end{array}$} & \multirow{2}{*}{$E L_{5000}$} & \multirow{2}{*}{$\begin{array}{l}\text { Non- } \\
\text { exceedance } \\
\text { percentile } \\
\text { for } E L_{5000}\end{array}$} & \multicolumn{3}{|c|}{$\begin{array}{l}\text { Regression residuals for the } \\
\text { specified AEP regression analyses }\end{array}$} \\
\hline & & & & & & & & & & & & $\begin{array}{l}\text { 10-percent } \\
\text { AEP }\end{array}$ & $\begin{array}{l}\text { 4-percent } \\
\text { AEP }\end{array}$ & $\begin{array}{c}\text { 1-percent } \\
\text { AEP }\end{array}$ \\
\hline \multicolumn{15}{|c|}{ Streamgages with significant leverage } \\
\hline 199 & 06114700 & $\begin{array}{l}\text { Judith River } \\
\text { near mouth, } \\
\text { near } \\
\text { Winifred, } \\
\text { Montana }\end{array}$ & 47.6684 & -109.6526 & CONT & Active & 16 & 2,747 & 100.0 & 29.0 & 96.9 & 0.171 & 0.184 & 0.233 \\
\hline 281 & 06137400 & $\begin{array}{l}\text { Big Sandy } \\
\text { Creek at } \\
\text { reservation } \\
\text { boundary, } \\
\text { near Rocky } \\
\text { Boy, Montana }\end{array}$ & 48.1724 & -109.8260 & CONT & Discontinued & 24 & 24.6 & 56.3 & 29.3 & 98.4 & 0.095 & 0.119 & 0.163 \\
\hline 283 & 06137580 & $\begin{array}{l}\text { Sage Creek near } \\
\text { Whitlash, } \\
\text { Montana }\end{array}$ & 48.8914 & -111.0311 & CONT & Discontinued & 12 & 7 & 43.8 & 30.5 & 100.0 & -0.043 & -0.110 & -0.191 \\
\hline 311 & ${ }^{2} 06151500$ & $\begin{array}{l}\text { Battle Creek } \\
\text { near Chinook, } \\
\text { Montana }\end{array}$ & 48.6495 & -109.2317 & CONT & Active & 49 & 1,468 & 98.4 & 0.0 & 1.6 & 0.032 & 0.164 & 0.287 \\
\hline 315 & ${ }^{2} 06154350$ & $\begin{array}{l}\text { Peoples Creek } \\
\text { tributary } \\
\text { near Lloyd, } \\
\text { Montana }\end{array}$ & 48.1922 & -109.3076 & CSG & Active & 41 & 2.60 & 21.9 & 14.6 & 95.3 & -0.174 & -0.058 & 0.103 \\
\hline 317 & 06154410 & $\begin{array}{l}\text { Little Peoples } \\
\text { Creek } \\
\text { near Hays, } \\
\text { Montana }\end{array}$ & 47.9658 & -108.6607 & CONT & Discontinued & 37 & 12.9 & 50.0 & 7.4 & 93.8 & 0.070 & 0.059 & 0.051 \\
\hline \multicolumn{15}{|c|}{ Streamgages with significant influence } \\
\hline 188 & 06109530 & $\begin{array}{l}\text { Little Sandy } \\
\text { Creek } \\
\text { tributary near } \\
\text { Virgelle, } \\
\text { Montana }\end{array}$ & 48.0864 & -109.9418 & CSG & Discontinued & 30 & 0.47 & 3.1 & 0.0 & 1.6 & -0.549 & -0.681 & -0.775 \\
\hline 280 & 06136400 & $\begin{array}{l}\text { Spring Coulee } \\
\text { tributary near } \\
\text { Simpson, } \\
\text { Montana }\end{array}$ & 48.9443 & -110.2160 & CSG & Discontinued & 30 & 2.76 & 25.0 & 0.0 & 1.6 & -0.563 & -0.559 & -0.573 \\
\hline
\end{tabular}


Table 18. Information on streamgages in the Northeast Plains hydrologic region with significant leverage and influence in the Montana regional regression analyses (Sando, R., and others, 2018).-Continued

[ID, identification; NAD 83, North American Datum of 1983; $n$, total number of years of peak-flow records; $C O N T D A$, contributing drainage area, in square miles; $E L_{5000}$, percentage of basin above 5,000 feet elevation; AEP, annual exceedance probability; CONT, continuous streamgage; CSG, crest-stage gage]

\begin{tabular}{|c|c|c|c|c|c|c|c|c|c|c|c|c|c|c|}
\hline \multirow{2}{*}{$\begin{array}{c}\text { Map } \\
\text { number } \\
\text { (fig. 1) }\end{array}$} & \multirow{2}{*}{$\begin{array}{l}\text { Streamgage } \\
\text { ID number }\end{array}$} & \multirow{2}{*}{$\begin{array}{l}\text { Streamgage } \\
\text { name }\end{array}$} & \multirow{2}{*}{$\begin{array}{c}\text { Latitude, } \\
\text { in decimal } \\
\text { degrees } \\
\text { (NAD 83) }\end{array}$} & \multirow{2}{*}{$\begin{array}{c}\text { Longitude, } \\
\text { in decimal } \\
\text { degrees } \\
\text { (NAD 83) }\end{array}$} & \multirow{2}{*}{$\begin{array}{c}\text { Type of } \\
\text { streamgage }\end{array}$} & \multirow{2}{*}{$\begin{array}{c}\text { Status of } \\
\text { streamgage } \\
\text { in water year } \\
2017\end{array}$} & \multirow{2}{*}{$n$} & \multirow{2}{*}{ CONTDA } & \multirow{2}{*}{$\begin{array}{c}\text { Non- } \\
\text { exceedance } \\
\text { percentile }{ }^{1} \\
\text { for CONTDA }\end{array}$} & \multirow{2}{*}{$E L_{5000}$} & \multirow{2}{*}{$\begin{array}{l}\text { Non- } \\
\text { exceedance } \\
\text { percentile } \\
\text { for } E L_{5000}\end{array}$} & \multicolumn{3}{|c|}{$\begin{array}{l}\text { Regression residuals for the } \\
\text { specified AEP regression analyses }\end{array}$} \\
\hline & & & & & & & & & & & & $\begin{array}{l}\text { 10-percent } \\
\text { AEP }\end{array}$ & $\begin{array}{l}\text { 4-percent } \\
\text { AEP }\end{array}$ & $\begin{array}{l}\text { 1-percent } \\
\text { AEP }\end{array}$ \\
\hline \multicolumn{15}{|c|}{ Streamgages with significant influence-Continued } \\
\hline 294 & 06142400 & $\begin{array}{l}\text { Clear Creek } \\
\text { near Chinook, } \\
\text { Montana }\end{array}$ & 48.5789 & -109.3911 & CONT & Active & 33 & 135 & 71.9 & 5.8 & 89.1 & -0.355 & -0.382 & -0.430 \\
\hline 311 & ${ }^{2} 06151500$ & $\begin{array}{l}\text { Battle Creek } \\
\text { near Chinook, } \\
\text { Montana }\end{array}$ & 48.6495 & -109.2317 & CONT & Active & 49 & 1,468 & 98.4 & 0.0 & 1.6 & 0.032 & 0.164 & 0.287 \\
\hline 315 & ${ }^{2} 06154350$ & $\begin{array}{c}\text { Peoples Creek } \\
\text { tributary } \\
\text { near Lloyd, } \\
\text { Montana }\end{array}$ & 48.1922 & -109.3076 & CSG & Active & 41 & 2.60 & 21.9 & 14.6 & 95.3 & -0.174 & -0.058 & 0.103 \\
\hline 341 & 06164600 & $\begin{array}{l}\text { Beaver Creek } \\
\text { tributary near } \\
\text { Zortman, } \\
\text { Montana }\end{array}$ & 47.9275 & -108.3527 & $\mathrm{CSG}$ & Active & 43 & 3.76 & 31.3 & 0.0 & 1.6 & 0.487 & 0.549 & 0.668 \\
\hline 343 & 06164623 & $\begin{array}{l}\text { Little Warm } \\
\text { Creek } \\
\text { tributary near } \\
\text { Lodge Pole, } \\
\text { Montana }\end{array}$ & 47.9952 & -108.3202 & $\begin{array}{r}\text { CONT, } \\
\text { CSG }\end{array}$ & Active & 34 & 2.39 & 17.2 & 0.0 & 1.6 & 0.573 & 0.567 & 0.572 \\
\hline 345 & 06165200 & $\begin{array}{c}\text { Guston Coulee } \\
\text { near Malta, } \\
\text { Montana }\end{array}$ & 48.2419 & -107.5486 & CSG & Active & 43 & 2.40 & 18.8 & 0.0 & 1.6 & -0.583 & -0.560 & -0.572 \\
\hline 403 & 06183750 & $\begin{array}{l}\text { Lake Creek } \\
\text { near Dagmar, } \\
\text { Montana }\end{array}$ & 48.5641 & -104.1776 & CONT & Discontinued & 19 & 111 & 68.8 & 0.0 & 1.6 & -0.668 & -0.572 & -0.459 \\
\hline 406 & 06184200 & $\begin{array}{l}\text { Lost Creek } \\
\text { tributary near } \\
\text { Homestead, } \\
\text { Montana }\end{array}$ & 48.4025 & -104.4975 & CSG & Active & 44 & 1.92 & 14.1 & 0.0 & 1.6 & 0.262 & 0.382 & 0.537 \\
\hline
\end{tabular}

${ }^{1}$ The nonexceedance percentile for the basin or climatic variable value was calculated in relation to the values for all streamgages included in the regional regression analyses for the indicated hydrologic region.

${ }^{2}$ Streamgages having both significant leverage and significant influence. 
Table 19. Information on discontinued streamgages in the Northeast Plains hydrologic region that might be candidates for reactivation to improve the streamgage network.

[NAD 83, North American Datum of $1983 ; n$, total number of years of peak-flow records; $C O N T D A$, contributing drainage area, in square miles; $E L_{5000}$, percentage of basin above 5,000 feet elevation; CONT, continuous streamgage; CSG, crest-stage gage]

\begin{tabular}{|c|c|c|c|c|c|c|c|c|c|c|}
\hline $\begin{array}{c}\text { Map } \\
\text { number } \\
\text { (fig. 1) }\end{array}$ & $\begin{array}{c}\text { Station } \\
\text { identification } \\
\text { number }\end{array}$ & Station name & $\begin{array}{l}\text { Latitude, } \\
\text { in decimal } \\
\text { degrees } \\
\text { (NAD 83) }\end{array}$ & $\begin{array}{c}\text { Longitude, } \\
\text { in decimal } \\
\text { degrees } \\
\text { (NAD 83) }\end{array}$ & $\begin{array}{c}\text { Type of } \\
\text { streamgage }\end{array}$ & $n$ & CONTDA & $\begin{array}{c}\text { Non- } \\
\text { exceedance } \\
\text { percentile } 1 \\
\text { for CONTDA }\end{array}$ & $E L_{5000}$ & $\begin{array}{c}\text { Non- } \\
\text { exceedance } \\
\text { percentile } 1 \\
\text { for } E L_{5000}\end{array}$ \\
\hline 281 & 06137400 & $\begin{array}{l}\text { Big Sandy Creek at reservation boundary, near Rocky } \\
\text { Boy, Montana }\end{array}$ & 48.1724 & -109.8260 & CONT & 24 & 24.6 & 56.3 & 29.3 & 98.4 \\
\hline 282 & 06137570 & Boxelder Creek near Rocky Boy, Montana & 48.3019 & -109.8443 & CONT & 22 & 48.3 & 59.4 & 5.7 & 87.5 \\
\hline 283 & 06137580 & Sage Creek near Whitlash, Montana & 48.8914 & -111.0311 & CONT & 12 & 7.43 & 43.8 & 30.5 & 100.0 \\
\hline 285 & 06137900 & England Coulee at Hingham, Montana & 48.5595 & -110.4217 & CSG & 15 & 1.61 & 9.4 & 0.0 & 1.6 \\
\hline 287 & 06138800 & Spring Coulee near Havre, Montana & 48.4208 & -109.8652 & CSG & 15 & 18.0 & 53.1 & 0.0 & 1.6 \\
\hline 290 & 06140400 & Bullhook Creek near Havre, Montana & 48.5076 & -109.6389 & CSG & 17 & 39.1 & 57.8 & 0.0 & 1.6 \\
\hline 292 & 06141600 & Little Boxelder Creek at mouth, near Havre, Montana & 48.5621 & -109.5323 & CONT & 10 & 95.9 & 67.2 & 6.7 & 90.6 \\
\hline 293 & 06141900 & Milk River tributary near Lohman, Montana & 48.5849 & -109.4295 & CSG & 15 & 0.18 & 1.6 & 0.0 & 1.6 \\
\hline 314 & 06154140 & Fifteenmile Creek tributary near Harlem, Montana & 48.3248 & -108.7083 & CONT & 10 & 2.11 & 15.6 & 0.0 & 1.6 \\
\hline 318 & 06154430 & Lodge Pole Creek at Lodge Pole, Montana & 48.0311 & -108.5326 & CONT & 14 & 19.5 & 54.7 & 6.9 & 92.2 \\
\hline 319 & 06154490 & Willow Creek near Dodson, Montana & 48.3251 & -108.4154 & CONT & 10 & 5.53 & 37.5 & 0.0 & 1.6 \\
\hline 323 & 06155100 & Black Coulee near Malta, Montana & 48.2121 & -108.0471 & CSG & 13 & 11.7 & 48.4 & 0.0 & 1.6 \\
\hline 324 & 06155200 & Alkali Creek near Malta, Montana & 48.2681 & -107.9662 & CSG & 18 & 184 & 78.1 & 0.0 & 1.6 \\
\hline 326 & 06155400 & South Fork Taylor Coulee near Malta, Montana & 48.3262 & -107.9147 & CSG & 19 & 4.93 & 34.4 & 0.0 & 1.6 \\
\hline 337 & 06163400 & Denniel Creek near Val Marie, Saskatchewan & 49.3073 & -107.7035 & CONT & 14 & 192 & 79.7 & 0.0 & 1.6 \\
\hline 342 & 06164615 & $\begin{array}{l}\text { Little Warm Creek at reservation boundary, near } \\
\text { Zortman, Montana }\end{array}$ & 47.9730 & -108.3629 & CONT & 10 & 5.75 & 39.1 & 0.0 & 1.6 \\
\hline 351 & 06170200 & Willow Creek near Hinsdale, Montana & 48.5650 & -106.9825 & CONT & 10 & 290 & 84.4 & 0.0 & 1.6 \\
\hline 352 & 06171000 & Rock Creek near Hinsdale, Montana & 48.4527 & -107.0365 & CONT & 11 & 1,300 & 96.9 & 0.0 & 1.6 \\
\hline 390 & 06179500 & West Fork Poplar River at international boundary & 49.0000 & -106.3683 & CONT & 20 & 145 & 73.4 & 0.0 & 1.6 \\
\hline 397 & 06182700 & Middle Fork Big Muddy Creek near Flaxville, Montana & 48.8022 & -105.1139 & CSG & 11 & 3.26 & 29.7 & 0.0 & 1.6 \\
\hline 399 & 06183100 & Box Elder Creek near Plentywood, Montana & 48.8238 & -104.4997 & CSG & 19 & 11.0 & 46.9 & 0.0 & 1.6 \\
\hline 401 & 06183400 & Spring Creek at Highway 16, near Plentywood, Montana & 48.7666 & -104.5252 & CSG & 19 & 15.4 & 51.6 & 0.0 & 1.6 \\
\hline 403 & 06183750 & Lake Creek near Dagmar, Montana & 48.5641 & -104.1776 & CONT & 19 & 111 & 68.8 & 0.0 & 1.6 \\
\hline 404 & 06183800 & Cottonwood Creek near Dagmar, Montana & 48.5092 & -104.1734 & CONT & 20 & 128 & 70.3 & 0.0 & 1.6 \\
\hline
\end{tabular}

${ }^{1}$ The nonexceedance percentile for the basin or climatic variable value was calculated in relation to the values for all streamgages included in the regional regression analyses for the indicated hydrologic region. 

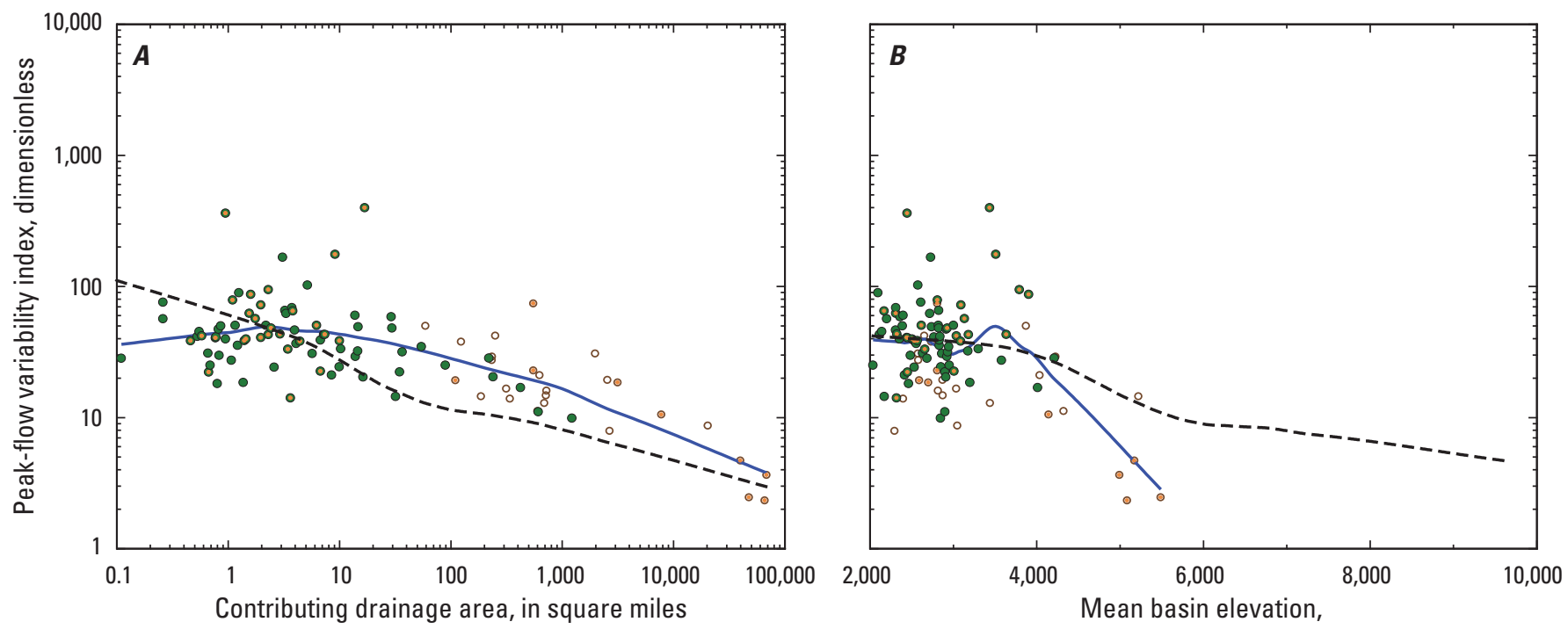

in feet above the North American Vertical Datum of 1988
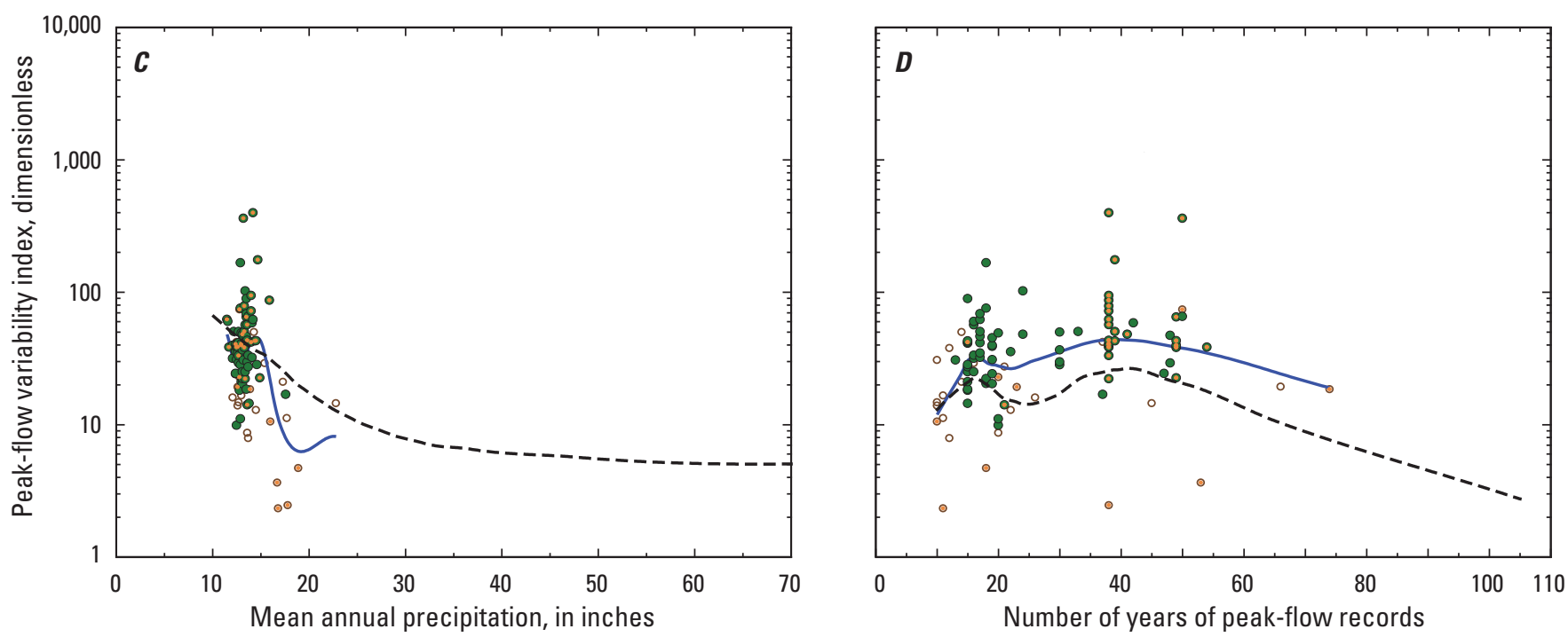

\section{EXPLANATION}

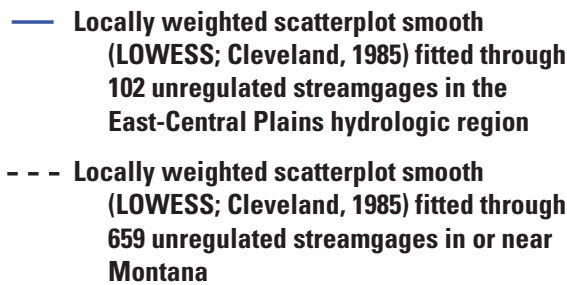

- Crest-stage streamgage

- Continuous streamgage

Interior dot denotes active streamgage

in water year 2017

Figure 18. Relations between peak-flow variability index and contributing drainage area, mean basin elevation, mean annual precipitation, and years of peak-flow records for 102 unregulated streamgages in the East-Central Plains hydrologic region. $A$, Peak-flow variability and contributing drainage area relations. $B$, Peak-flow variability and mean basin elevation relations. $C$, Peak-flow variability and mean annual precipitation relations. $D$, Peak-flow variability and years of peak-flow records relations. 


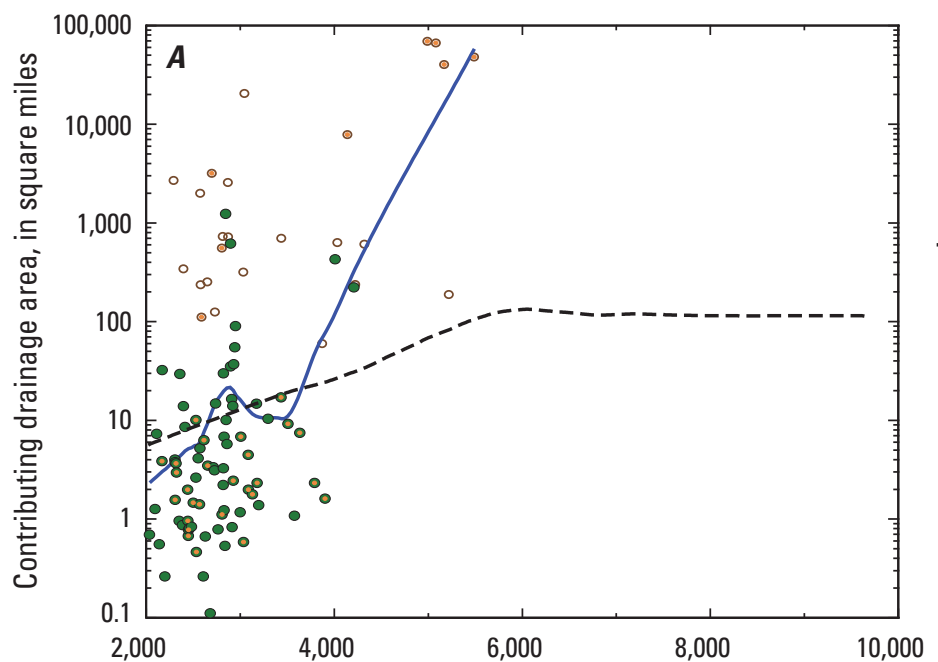

\section{EXPLANATION}

- Locally weighted scatterplot smooth (LOWESS; Cleveland, 1985) fitted through

102 unregulated streamgages in the

East-Central Plains hydrologic region

- - - Locally weighted scatterplot smooth (LOWESS; Cleveland, 1985) fitted through 659 unregulated streamgages in or near Montana

- Crest-stage streamgage

- Continuous streamgage

Interior dot denotes active streamgage in water year 2017

Mean basin elevation, in feet above the North American Vertical Datum of 1988
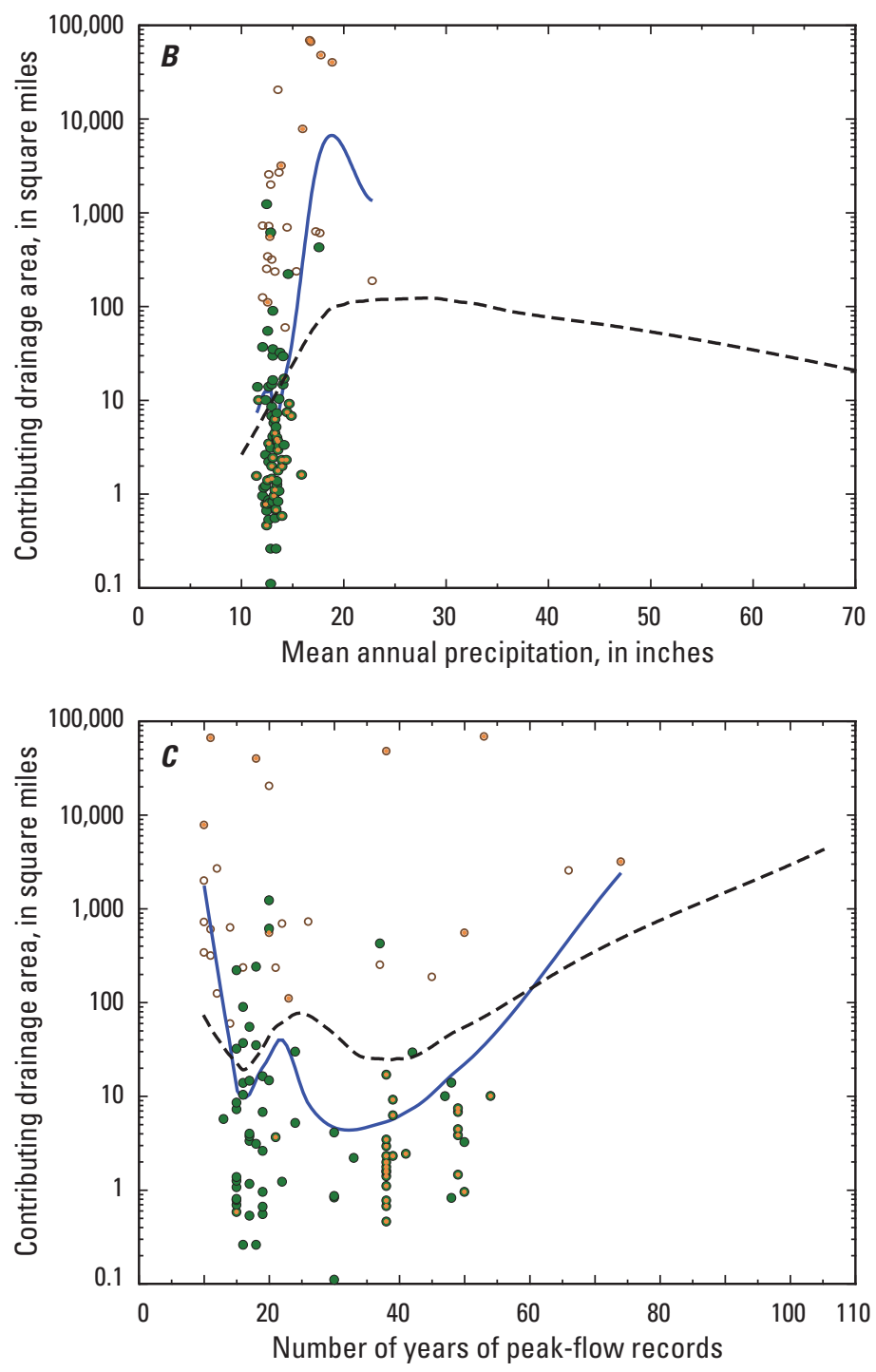

Figure 19. Relations between contributing drainage area and mean basin elevation, mean annual precipitation, and years of peak-flow records for 102 unregulated streamgages in the East-Central Plains hydrologic region. $A$, Contributing drainage area and mean basin elevation relations. $B$, Contributing drainage area and mean annual precipitation relations. $C$, Contributing drainage area and years of peak-flow records relations. 


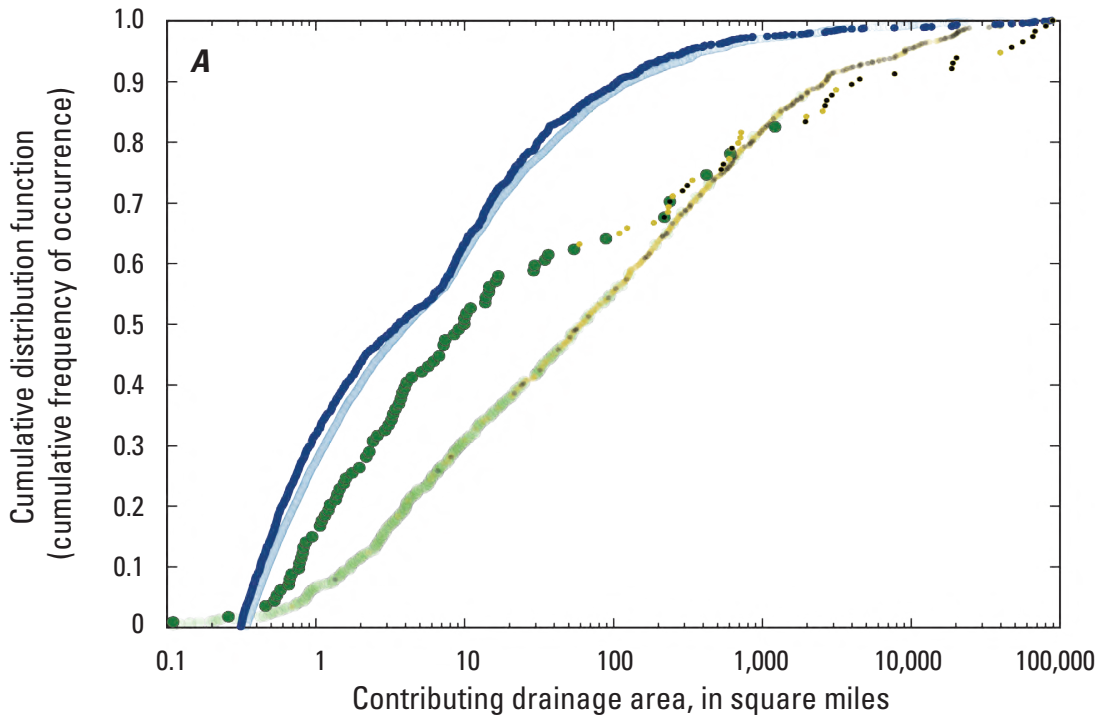

\section{EXPLANATION}

- Road and stream intersection in the East-Central Plains hydrologic region

One of 12,639 road and stream intersections in Montana, as shown in figure 5-0pen symbols appear as solid symbols because of the high data density

Regulated and unregulated streamgages in the East-Central Plains hydrologic region

- Crest-stage streamgage

- Unregulated continuous streamgage

- Regulated continuous streamgage

Regulated and unregulated streamgages in or near Montana, as shown in figure 5

Crest-stage streamgage in or near Montana Unregulated streamgages in or near Montana

Regulated streamgages in or near Montana
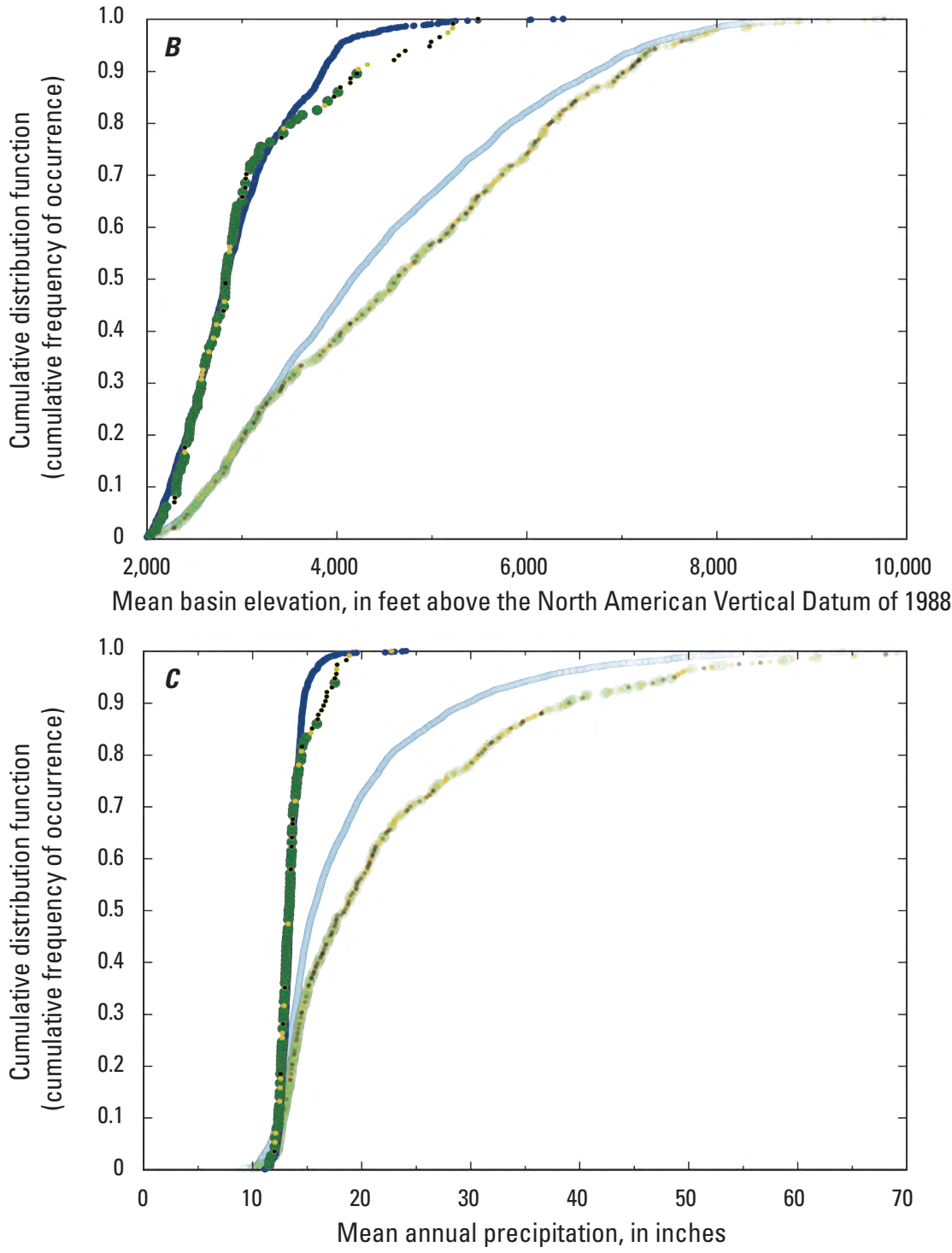

Figure 20. Cumulative distribution functions of selected drainage-basin characteristics for 1,586 road and stream intersections and for 114 streamgages (regulated and unregulated) in the East-Central Plains hydrologic region. $A$, Contributing drainage area relations. $B$, Mean basin elevation relations. $C$, Mean annual precipitation relations. 
and others, 2021) with a median of 13.4 inches (table 5). The range for the East-Central Plains hydrologic region is smaller than for all of Montana (8.4-91.3 ft; Dutton and others, 2021) and the median for the East-Central Plains hydrologic region is somewhat smaller than for all of Montana (15.7 inches; table 5). There are substantial differences between the CDFs of road and stream intersections for the East-Central Plains hydrologic region relative to the CDFs of road and stream intersections for all of Montana (fig. 20C). With respect to mean annual precipitation, the pattern of the streamgage CDF reasonably represents the road and stream intersection CDF but with small underrepresentation in a small range of mean annual precipitation from about 15 to 16 inches.

The explanatory variables for the East-Central Plains hydrologic region RREs are CONTDA, percentage of basin with slope greater than 30 percent (SLOP30_30M), and mean spring (March-June) evapotranspiration (ET0306MOD; table 6). The 1-percent AEP RRE for the East-Central Plains hydrologic region has an SEP of 73.5 percent, which is higher than the area-weighted mean SEP for all hydrologic regions in Montana (63.3 percent; table 6). For the 1-percent AEP regression for the East-Central Plains hydrologic region, 7.8 percent of the streamgages have significant leverage and 10.0 percent of the streamgages have significant influence (table 7); these percentages generally are similar to significant leverage and influence percentages (8.2 and 10.4 percent, respectively; table 7) for all of the streamgages in Montana used in the regional regression analyses.

Information on streamgages in the East-Central Plains hydrologic region with significant leverage and influence is presented in table 20. One of the seven significant leverage streamgages has the largest CONTDA (nonexceedance percentile equal to 100 percent). Four of the seven significant leverage streamgages have high SLOP30_30M values (nonexceedance percentiles greater than about 97 percent). Two of the seven significant leverages streamgages has a high $E T 0306 M O D$ value (nonexceedance percentile greater than about 99 percent), and one has a low ET0306MOD value (nonexceedance percentile less than about 6 percent). The 11 streamgages with significant influence vary with respect to the residuals for the 1-percent AEP RRE; five of the streamgages have negative residuals, and six have positive residuals. The three streamgages with both significant leverage and significant influence have negative residuals.

In general, the streamgage network in the East-Central Plains hydrologic region is considered to provide generally reasonable representation of the hydroclimatic settings of that hydrologic region. The RREs of the East-Central Plains hydrologic region are considered to be reasonably reliable. However, small basins (CONTDA less than about $17 \mathrm{mi}^{2}$ ) are more strongly represented in the East-Central Plains hydrologic region than the other hydrologic regions; greater variability in annual peak flows in small basins might contribute to the large SEP (73.5 percent) for the 1-percent AEP RRE for the East-Central Plains hydrologic region. Possible shortcomings of the streamgage network in the East-Central
Plains hydrologic region include underrepresentation of basins with CONTDA from about 17 to $220 \mathrm{mi}^{2}$, mean elevation from about 3,600 to $4,000 \mathrm{ft}$, and (or) mean annual precipitation from about 15 to 16 inches. Future improvements to the streamgage network in the East-Central Plains hydrologic region might include discontinuing some CSGs on basins with drainage areas less than about $17 \mathrm{mi}^{2}$ and reactivating discontinued streamgages as CSGs on drainage basins within the specified underrepresented characteristics. Establishing new CSGs on basins with drainage areas from about 17 to $220 \mathrm{mi}^{2}$ might also be warranted to appropriately distribute CONTDA representation in the streamgage network. In addition to possibly providing better representation of the road and stream intersections network, redistributing some CSGs from smaller to larger basins might be beneficial for regional regression analyses. Because larger basins integrate hydroclimatic characteristics of multiple smaller basins, appropriate representation of larger basins might assist in developing efficient regression relations. Information on discontinued streamgages in the East-Central Plains hydrologic region that might be candidates for reactivation to improve the streamgage network is presented in table 21 .

\section{Peak-Flow Variability, Peak-Flow Informational Needs, and Consideration of Regional Regression Analyses in the Southeast Plains Hydrologic Region}

The Southeast Plains hydrologic region has an area of $18,520 \mathrm{mi}^{2}$ (table 1), which ranks fifth largest among the eight hydrologic regions. The Level III ecoregion (table 2) represented in the Southeast Plains hydrologic region is the Northwestern Great Plains (100.0 percent). The 1,371 road and stream intersections in the Southeast Plains hydrologic region (tables 4 and 5) represent a density of 0.074 road and stream intersection per $\mathrm{mi}^{2}$, which ranks fifth among the hydrologic regions. The 80 streamgages (both regulated and unregulated; tables 4 and 5) represent an areal density of 0.00432 streamgage per $\mathrm{mi}^{2}$ (ranking sixth among hydrologic regions) and a density of 0.05835 streamgage per road and stream intersection (ranking fifth among hydrologic regions).

Relations between $P F V I$ and contributing drainage area, mean basin elevation, mean annual precipitation, and years of peak-flow records for 74 unregulated streamgages in the Southeast Plains hydrologic region (table 3 ) are presented in figure 21. For the 74 unregulated streamgages, PFVI generally monotonically decreases with increasing drainage area (fig. 21A) with somewhat inconsistent variability about the LOWESS line, possibly affected by poor representation of basins with drainage areas greater than about $20 \mathrm{mi}^{2}$. Intuitively, highly variable small-scale hydroclimatic processes are integrated with increasing drainage area such that variability in many hydrologic characteristics is reduced. For the relation between PFVI and drainage area (fig. 21A), the LOWESS line for the Southeast Plains hydrologic region 
generally is above the LOWESS line for all unregulated streamgages in Montana. For streamgages in the Southeast Plains hydrologic region, mean basin elevation and mean annual precipitation generally are within small ranges, and it is difficult to discern clear patterns in the relations between $P F V I$ and those variables (figs. $21 B$ and $21 C$ ); however, within the small ranges, the LOWESS lines for the Southeast Plains region generally are similar to the LOWESS lines for all unregulated streamgages in Montana. The relation between PFVI and years of peak-flow records for the Southeast Plains hydrologic region generally is similar to the relation for all unregulated streamgages in Montana, but the LOWESS line for the Southeast Plains hydrologic region is consistently above the LOWESS line for all unregulated streamgages in Montana (fig. 21D).

Relations between contributing drainage area and mean basin elevation, mean annual precipitation, and years of peakflow records for the unregulated streamgages are presented in figure 22. In the relations between contributing drainage area and mean basin elevation and mean annual precipitation (figs. 22A and 22B), the small ranges in mean basin elevation and mean annual precipitation in the Southeast Plains hydrologic region make it difficult to discern clear patterns in the relations. Relations between contributing drainage area and mean basin elevation (fig. $22 \mathrm{~A}$ ) indicate that all streamgages at lower elevations (less than about 3,000 ft) have smaller drainage areas (less than about $20 \mathrm{mi}^{2}$ ). In the relation between contributing drainage area and years of peakflow records (fig. 22C), the LOWESS line for the Southeast Plains hydrologic region generally is below the LOWESS line for all unregulated streamgages in Montana, indicating that streamgages on small basins generally have longer periods of record in the Southeast Plains hydrologic region than in Montana as a whole.

The median PFVI value for streamgages in the Southeast Plains hydrologic region (35.21, table 3 ) is substantially larger than the median for all unregulated streamgages in Montana (18.26, table 3) and ranks as the second largest median PFVI among the eight hydrologic regions. For unregulated streamgages in the Southeast Plains hydrologic region, fall and winter (October-February) precipitation accounts for about 20.7 percent of annual precipitation (table 8), which ranks fifth largest among the eight hydrologic regions. May-June precipitation accounts for about 34.6 percent of annual precipitation (table 8), which ranks fourth among the hydrologic regions, and July-August precipitation accounts for 19.8 percent of annual precipitation, which ranks fourth among the eight hydrologic regions. In the Southeast Plains hydrologic region, annual peak flows are most frequently in March and June (fig. 2 of Sando, R., and others, 2018), probably resulting from low-elevation snowmelt runoff and springtime rainfall runoff, respectively; however, substantial proportions of annual peak flows also are in February, April-May, and July-September. Generally small accumulated snowpacks, variability in the timing and magnitude of low-elevation snowmelt runoff, and variability in spring and summer rainfall might contribute to greater peak-flow variability in the Northwest Foothills hydrologic region than for Montana as a whole.

No streamgages in the Southeast Plains hydrologic region are considered to have mixed-population characteristics (table 1) that result in a small number of unusually large peak flows that are substantially larger than the main body of peak flows. Mixed-population peak-flow datasets are not a substantial consideration in the Southeast Plains hydrologic region.

The CDFs of selected basin characteristics (drainage area, mean basin elevation, and mean annual precipitation) for the road and stream intersections and for the streamgages in the Southeast Plains hydrologic region are shown in figure 23. With respect to drainage area, the CDF of road and stream intersections for the Southeast Plains hydrologic region is similar to the CDF of road and stream intersections for all of Montana (fig. 23A). In the Southeast Plains hydrologic region, the CDF of streamgages diverges from and is substantially above the CDF of streamgages for Montana as a whole in the range of drainage areas less than about $20 \mathrm{mi}^{2}$, indicating that small basins are more strongly represented in the Southeast Plains hydrologic region. It is noteworthy that about 63 percent of the streamgages (both regulated and unregulated) in the Southeast Plains hydrologic region are on basins with drainage areas less than about $20 \mathrm{mi}^{2}$, whereas the other 37 percent of the streamgages are distributed over a large range in drainage areas from about 20 to several thousand square miles. In the Southeast Plains hydrologic region, the CDF of streamgages diverges from the CDF of road and stream intersections in the range of drainage areas from about 20 to $370 \mathrm{mi}^{2}$, indicating underrepresentation in that range.

The Southeast Plains hydrologic region generally is lower in elevation than Montana as a whole. Mean basin elevation for road and stream intersections in the Southeast Plains hydrologic region ranges from 2,092 to 6,128 ft (Dutton and others, 2021) with a median of 3,194 ft (table 4). The range for the Southeast Plains hydrologic region is smaller than for all of Montana (1,951-9,974 ft; Dutton and others, 2021) and the median for the Southeast Plains hydrologic region is less than for all of Montana (4,173 ft; table 4). There are substantial differences between the CDFs of road and stream intersections for the Southeast Plains hydrologic region relative to the CDFs of road and stream intersections for all of Montana (fig. 23B). With respect to mean basin elevation, the pattern of the streamgage CDF reasonably represents the road and stream intersection CDF but with small underrepresentation in a small range of elevations from about 3,600 to 4,200 ft.

The Southeast Plains hydrologic region generally is drier than Montana as a whole. Mean annual precipitation for road and stream intersections in the Southeast Plains hydrologic region ranges from 12.1 to 21.6 inches (Dutton and others, 2021) with a median of 14.5 inches (table 5). The range for the Southeast Plains hydrologic region is smaller than for all of Montana (8.4-91.3 ft; Dutton and others, 2021) and the median for the Southeast Plains hydrologic region is somewhat smaller than for all of Montana (15.7 inches; table 5). 
Table 20. Information on streamgages in the East-Central Plains hydrologic region with significant leverage and influence in the Montana regional regression analyses (Sando, R., and others, 2018).

[ID, identification; NAD 83, North American Datum of 1983; $n$, total number of years of peak-flow records; CONTDA, contributing drainage area, in square miles; SLOP30_30M, percentage of basin in slopes greater than or equal to 30 percent; ET0306MOD, spring mean monthly evapotranspiration, in inches per month; AEP, annual exceedance probability; CONT, continuous streamgage; CSG, crest-stage gage]

\begin{tabular}{|c|c|c|c|c|c|c|c|}
\hline $\begin{array}{c}\text { Map } \\
\text { number } \\
\text { (fig. 1) }\end{array}$ & $\begin{array}{l}\text { Streamgage } \\
\text { ID number }\end{array}$ & Streamgage name & $\begin{array}{l}\text { Latitude, } \\
\text { in decimal } \\
\text { degrees } \\
\text { (NAD 83) }\end{array}$ & $\begin{array}{c}\text { Longitude, } \\
\text { in decimal } \\
\text { degrees } \\
\text { (NAD 83) }\end{array}$ & $\begin{array}{c}\text { Type of } \\
\text { streamgage }\end{array}$ & $\begin{array}{c}\text { Status of } \\
\text { streamgage } \\
\text { in water } \\
\text { year } 2017\end{array}$ & $n$ \\
\hline \multicolumn{8}{|c|}{ Streamgages with significant leverage } \\
\hline 239 & 206127900 & Flatwillow Creek near Flatwillow, Montana & 46.7912 & -108.6142 & CONT & Discontinued & 45 \\
\hline 248 & 06129500 & McDonald Creek at Winnett, Montana & 46.9936 & -108.3564 & CONT, CSG & Discontinued & 37 \\
\hline 263 & 06131000 & Big Dry Creek near Van Norman, Montana & 47.3494 & -106.3578 & CONT & Discontinued & 69 \\
\hline 489 & 06294800 & Unknown Creek near Bighorn, Montana & 46.1970 & -107.4092 & CSG & Discontinued & 17 \\
\hline 499 & 06295050 & Little Porcupine Creek near Forsyth, Montana & 46.3044 & -106.5751 & CSG & Discontinued & 20 \\
\hline 554 & 206326550 & Cherry Creek tributary near Terry, Montana & 46.8551 & -105.3412 & CSG & Discontinued & 19 \\
\hline 564 & ${ }^{2} 06327450$ & Cains Coulee at Glendive, Montana & 47.0942 & -104.7133 & CONT, CSG & Active & 26 \\
\hline \multicolumn{8}{|c|}{ Streamgages with significant influence } \\
\hline 202 & 06115100 & Missouri River tributary near Landusky, Montana & 47.6262 & -108.6986 & CSG & Discontinued & 17 \\
\hline 239 & ${ }^{2} 06127900$ & Flatwillow Creek near Flatwillow, Montana & 46.7912 & -108.6142 & CONT & Discontinued & 45 \\
\hline 367 & 06175900 & $\begin{array}{l}\text { Wolf Creek tributary No. } 2 \text { near Wolf Point, } \\
\text { Montana }\end{array}$ & 48.2017 & -105.7538 & CSG & Discontinued & 30 \\
\hline 368 & 06176500 & Wolf Creek near Wolf Point, Montana & 48.0972 & -105.6802 & CONT & Discontinued & 37 \\
\hline 369 & 06176950 & $\begin{array}{l}\text { Missouri River tributary No. } 6 \text { near Wolf Point, } \\
\text { Montana }\end{array}$ & 48.0563 & -105.5569 & CSG & Discontinued & 19 \\
\hline 371 & 06177020 & Tule Creek tributary near Wolf Point, Montana & 48.2446 & -105.4927 & $\mathrm{CSG}$ & Active & 43 \\
\hline 381 & 06177700 & Cow Creek tributary near Vida, Montana & 47.7158 & -105.4945 & CONT, CSG & Active & 53 \\
\hline 383 & 06177800 & Gady Coulee near Vida, Montana & 47.9127 & -105.4971 & CSG & Discontinued & 30 \\
\hline 412 & 06185400 & $\begin{array}{l}\text { Missouri River tributary No. } 5 \text { at Culbertson, } \\
\text { Montana }\end{array}$ & 48.1587 & -104.5161 & CSG & Active & 54 \\
\hline 554 & ${ }^{2} 06326550$ & Cherry Creek tributary near Terry, Montana & 46.8551 & -105.3412 & CSG & Discontinued & 19 \\
\hline 564 & ${ }^{2} 06327450$ & Cains Coulee at Glendive, Montana & 47.0942 & -104.7133 & CONT, CSG & Active & 26 \\
\hline
\end{tabular}

${ }^{1}$ The nonexceedance percentile for the basin or climatic variable value was calculated in relation to the values for all streamgages included in the regional regression analyses for the indicated hydrologic region.

${ }^{2}$ Streamgages having both significant leverage and significant influence. 


\begin{tabular}{|c|c|c|c|c|c|c|c|c|}
\hline \multirow{2}{*}{ CONTDA } & \multirow{2}{*}{$\begin{array}{c}\text { Nonexceedance } \\
\text { percentile }{ }^{1} \text { for } \\
\text { CONTDA }\end{array}$} & \multirow{2}{*}{ SLOP30_30M } & \multirow{2}{*}{$\begin{array}{c}\text { Nonexceedance } \\
\text { percentile }^{1} \text { for } \\
\text { SLOP30_30M }\end{array}$} & \multirow{2}{*}{ ET0306MOD } & \multirow{2}{*}{$\begin{array}{c}\text { Nonexceedance } \\
\text { percentile }^{1} \text { for } \\
\text { ET0306MOD }\end{array}$} & \multicolumn{3}{|c|}{$\begin{array}{c}\text { Regression residuals for the } \\
\text { specified AEP regression analyses }\end{array}$} \\
\hline & & & & & & $\begin{array}{l}\text { 10-percent } \\
\text { AEP }\end{array}$ & $\begin{array}{l}\text { 4-percent } \\
\text { AEP }\end{array}$ & $\begin{array}{l}\text { 1-percent } \\
\text { AEP }\end{array}$ \\
\hline \multicolumn{9}{|c|}{ Streamgages with significant leverage } \\
\hline 187 & 82.2 & 16.47 & 98.9 & 1.57 & 100.0 & -0.200 & -0.327 & -0.429 \\
\hline 424 & 90.0 & 3.81 & 87.8 & 1.45 & 98.9 & 0.009 & -0.104 & -0.222 \\
\hline 14.6 & 68.9 & 13.10 & 97.8 & 1.11 & 68.9 & 0.135 & 0.112 & 0.105 \\
\hline 611 & 92.2 & 0.22 & 61.1 & 0.91 & 5.6 & -0.068 & -0.097 & -0.098 \\
\hline 2.60 & 38.9 & 10.45 & 96.7 & 0.93 & 6.7 & -0.456 & -0.585 & -0.720 \\
\hline 3.64 & 45.6 & 31.87 & 100.0 & 0.95 & 11.1 & 0.216 & 0.034 & -0.168 \\
\hline 0.86 & 16.7 & 0.00 & 1.1 & 1.00 & 27.8 & 0.685 & 0.715 & 0.741 \\
\hline 251 & 86.7 & 0.01 & 43.3 & 1.12 & 72.2 & 0.391 & 0.518 & 0.660 \\
\hline 0.55 & 6.7 & 0.05 & 51.1 & 1.02 & 35.6 & -0.427 & -0.567 & -0.737 \\
\hline 1.97 & 32.2 & 0.00 & 1.1 & 1.15 & 80.0 & -0.186 & -0.324 & -0.497 \\
\hline 1.45 & 27.8 & 0.00 & 1.1 & 1.11 & 64.4 & 0.437 & 0.424 & 0.415 \\
\hline 0.83 & 15.6 & 0.00 & 1.1 & 1.16 & 85.6 & 0.851 & 0.792 & 0.726 \\
\hline 3.82 & 47.8 & 0.30 & 65.6 & 1.19 & 88.9 & 0.355 & 0.422 & 0.499 \\
\hline
\end{tabular}


[NAD 83, North American Datum of 1983; $n$, total number of years of peak-flow records; CONTDA, contributing drainage area, in square miles; SLOP30_30M, percentage of basin in slopes greater than or equal to 30 percent; $E T 0306 \mathrm{MOD}$, spring mean monthly evapotranspiration, in inches per month; CSG, crest-stage gage; CONT, continuous streamgage]

\begin{tabular}{|c|c|c|c|c|c|c|c|c|c|c|c|c|}
\hline $\begin{array}{l}\text { Map } \\
\text { number } \\
\text { (fig. 1) }\end{array}$ & $\begin{array}{c}\text { Station } \\
\text { identification } \\
\text { number }\end{array}$ & Station name & $\begin{array}{l}\text { Latitude, } \\
\text { in decimal } \\
\text { degrees } \\
\text { (NAD 83) }\end{array}$ & $\begin{array}{c}\text { Longitude, } \\
\text { in decimal } \\
\text { degrees } \\
\text { (NAD 83) }\end{array}$ & $\begin{array}{c}\text { Type of } \\
\text { streamgage }\end{array}$ & $n$ & CONTDA & $\begin{array}{c}\text { Non- } \\
\text { exceedance } \\
\text { percentile }{ }^{1} \text { for } \\
\text { CONTDA }\end{array}$ & SLOP30_30M & $\begin{array}{c}\text { Non- } \\
\text { exceedance } \\
\text { percentile' for } \\
\text { SLOP30_30M }\end{array}$ & ET0306MOD & $\begin{array}{c}\text { Non- } \\
\text { exceedance } \\
\text { percentile }{ }^{1} \text { for } \\
\text { ET0306MOD }\end{array}$ \\
\hline 202 & 06115100 & $\begin{array}{l}\text { Missouri River } \\
\text { tributary near } \\
\text { Landusky, } \\
\text { Montana }\end{array}$ & 47.6262 & -108.6986 & CSG & 17 & 3.32 & 43.3 & 8.1 & 95.6 & 1.090 & 60.0 \\
\hline 227 & 06125700 & $\begin{array}{l}\text { Big Coulee Creek } \\
\text { near Lavina, } \\
\text { Montana }\end{array}$ & 46.2645 & -108.9478 & CONT & 16 & 235 & 85.6 & 5.3 & 91.1 & 1.169 & 87.8 \\
\hline 230 & 06126470 & $\begin{array}{l}\text { Halfbreed Creek } \\
\text { near Klein, } \\
\text { Montana }\end{array}$ & 46.3872 & -108.5418 & CONT & 14 & 59.30 & 77.8 & 7.6 & 94.4 & 1.206 & 90.0 \\
\hline 232 & 06127100 & $\begin{array}{l}\text { South Willow } \\
\text { Creek tributary } \\
\text { near Roundup, } \\
\text { Montana }\end{array}$ & 46.5147 & -108.5783 & CSG & 15 & 1.07 & 20.0 & 0.0 & 1.1 & 1.001 & 26.7 \\
\hline 233 & 06127200 & $\begin{array}{l}\text { Musselshell River } \\
\text { tributary near } \\
\text { Musselshell, } \\
\text { Montana }\end{array}$ & 46.5071 & -108.2549 & $\mathrm{CSG}$ & 16 & 10.3 & 64.4 & 0.1 & 51.1 & 1.070 & 52.2 \\
\hline 243 & 06128900 & $\begin{array}{l}\text { Box Elder Creek } \\
\text { tributary } \\
\text { near Winnett, } \\
\text { Montana }\end{array}$ & 47.0163 & -108.1599 & CSG & 19 & 16.3 & 71.1 & 0.0 & 43.3 & 1.021 & 34.4 \\
\hline 244 & 06129000 & $\begin{array}{l}\text { Box Elder Creek } \\
\text { near Winnett, } \\
\text { Montana }\end{array}$ & 47.0125 & -108.1553 & CONT & 22 & 691 & 94.4 & 2.9 & 85.6 & 1.210 & 91.1 \\
\hline 252 & 06130600 & $\begin{array}{l}\text { Cat Creek near } \\
\text { Cat Creek, } \\
\text { Montana }\end{array}$ & 47.0432 & -108.0158 & CSG & 18 & 34.8 & 74.4 & 0.3 & 67.8 & 1.030 & 37.8 \\
\hline 256 & 06130800 & $\begin{array}{l}\text { Second Creek } \\
\text { tributary } \\
\text { near Jordan, } \\
\text { Montana }\end{array}$ & 47.1919 & -106.8024 & $\mathrm{CSG}$ & 17 & 0.53 & 5.6 & 0.0 & 1.1 & 0.942 & 10.0 \\
\hline 258 & 06130900 & $\begin{array}{l}\text { Second Creek } \\
\text { tributary No. } \\
3 \text { near Jordan, } \\
\text { Montana }\end{array}$ & 47.2193 & -106.8260 & CSG & 15 & 0.78 & 12.2 & 0.0 & 1.1 & 1.147 & 78.9 \\
\hline
\end{tabular}


Table 21. Information on discontinued streamgages in the East-Central Plains hydrologic region that might be candidates for reactivation to improve the streamgage network.-Continued

[NAD 83, North American Datum of 1983; $n$, total number of years of peak-flow records; CONTDA, contributing drainage area, in square miles; SLOP30_30M, percentage of basin in slopes greater than or equal to 30 percent; $E T 0306 M O D$, spring mean monthly evapotranspiration, in inches per month; CSG, crest-stage gage; CONT, continuous streamgage]

\begin{tabular}{|c|c|c|c|c|c|c|c|c|c|c|c|c|}
\hline $\begin{array}{l}\text { Map } \\
\text { number } \\
\text { (fig. 1) }\end{array}$ & $\begin{array}{c}\text { Station } \\
\text { identification } \\
\text { number }\end{array}$ & Station name & $\begin{array}{l}\text { Latitude, } \\
\text { in decimal } \\
\text { degrees } \\
\text { (NAD 83) }\end{array}$ & $\begin{array}{c}\text { Longitude, } \\
\text { in decimal } \\
\text { degrees } \\
\text { (NAD 83) }\end{array}$ & $\begin{array}{c}\text { Type of } \\
\text { streamgage }\end{array}$ & $n$ & CONTDA & $\begin{array}{c}\text { Non- } \\
\text { exceedance } \\
\text { percentile }{ }^{1} \text { for } \\
\text { CONTDA }\end{array}$ & SLOP30_30M & $\begin{array}{c}\text { Non- } \\
\text { exceedance } \\
\text { percentile' } 1 \text { for } \\
\text { SLOP30_30M }\end{array}$ & ET0306MOD & $\begin{array}{l}\text { Non- } \\
\text { exceedance } \\
\text { percentile }{ }^{1} \text { for } \\
\text { ET0306MOD }\end{array}$ \\
\hline 260 & 06130925 & $\begin{array}{l}\text { Thompson Creek } \\
\text { tributary near } \\
\text { Cohagen, } \\
\text { Montana }\end{array}$ & 46.9513 & -106.4613 & $\mathrm{CSG}$ & 22 & 1.22 & 23.3 & 0.0 & 1.1 & 0.997 & 24.4 \\
\hline 262 & 06130950 & $\begin{array}{l}\text { Little Dry } \\
\text { Creek near } \\
\text { Van Norman, } \\
\text { Montana }\end{array}$ & 47.3394 & -106.3636 & $\mathrm{CSG}$ & 20 & 1,223 & 97.8 & 0.1 & 54.4 & 1.041 & 43.3 \\
\hline 354 & 06172200 & $\begin{array}{l}\text { Buggy Creek } \\
\text { near Tampico, } \\
\text { Montana }\end{array}$ & 48.3608 & -106.7779 & CONT & 12 & 124 & 81.1 & 0.1 & 57.8 & 1.081 & 56.7 \\
\hline 357 & 06172350 & $\begin{array}{l}\text { Mooney Coulee } \\
\text { near Tampico, } \\
\text { Montana }\end{array}$ & 48.2859 & -106.7092 & CSG & 16 & 13.8 & 66.7 & 0.0 & 1.1 & 1.038 & 40.0 \\
\hline 358 & 06173300 & $\begin{array}{l}\text { Willow Creek } \\
\text { tributary near } \\
\text { Fort Peck, } \\
\text { Montana }\end{array}$ & 47.8931 & -106.8903 & CSG & 19 & 0.95 & 17.8 & 0.0 & 1.1 & 0.896 & 1.1 \\
\hline 364 & 06175540 & $\begin{array}{l}\text { Prairie Elk Creek } \\
\text { near Oswego, } \\
\text { Montana }\end{array}$ & 47.9990 & -105.8674 & CONT & 10 & 340 & 88.9 & 0.5 & 74.4 & 1.017 & 31.1 \\
\hline 365 & 06175550 & $\begin{array}{l}\text { East Fork Sand } \\
\text { Creek near } \\
\text { Vida, Montana }\end{array}$ & 47.8042 & -105.6143 & $\mathrm{CSG}$ & 15 & 8.51 & 60.0 & 0.0 & 1.1 & 1.045 & 44.4 \\
\hline 369 & 06176950 & $\begin{array}{l}\text { Missouri River } \\
\text { tributary No. } \\
6 \text { near Wolf } \\
\text { Point, Montana }\end{array}$ & 48.0563 & -105.5569 & CSG & 19 & 0.55 & 6.7 & 0.1 & 51.1 & 1.024 & 35.6 \\
\hline 373 & 06177100 & $\begin{array}{l}\text { Duck Creek near } \\
\text { Brockway, } \\
\text { Montana }\end{array}$ & 47.2391 & -105.8171 & CSG & 17 & 54.6 & 76.7 & 0.4 & 71.1 & 1.114 & 67.8 \\
\hline 375 & 06177200 & $\begin{array}{l}\text { Tusler Creek near } \\
\text { Brockway, } \\
\text { Montana }\end{array}$ & 47.2972 & -105.6635 & CSG & 16 & 89.4 & 78.9 & 0.4 & 68.9 & 1.154 & 84.4 \\
\hline
\end{tabular}


Table 21. Information on discontinued streamgages in the East-Central Plains hydrologic region that might be candidates for reactivation to improve the streamgage

network.-Continued

[NAD 83, North American Datum of 1983; $n$, total number of years of peak-flow records; CONTDA, contributing drainage area, in square miles; SLOP30 $30 M$, percentage of basin in slopes greater than or equal to 30 percent; $E T 0306 M O D$, spring mean monthly evapotranspiration, in inches per month; CSG, crest-stage gage; CONT, continuous streamgage]

\begin{tabular}{|c|c|c|c|c|c|c|c|c|c|c|c|c|}
\hline $\begin{array}{l}\text { Map } \\
\text { number } \\
\text { (fig. 1) }\end{array}$ & $\begin{array}{c}\text { Station } \\
\text { identification } \\
\text { number }\end{array}$ & Station name & $\begin{array}{l}\text { Latitude, } \\
\text { in decimal } \\
\text { degrees } \\
\text { (NAD 83) }\end{array}$ & $\begin{array}{c}\text { Longitude, } \\
\text { in decimal } \\
\text { degrees } \\
\text { (NAD 83) }\end{array}$ & $\begin{array}{c}\text { Type of } \\
\text { streamgage }\end{array}$ & $n$ & CONTDA & $\begin{array}{l}\text { Non- } \\
\text { exceedance } \\
\text { percentile }{ }^{1} \text { for } \\
\text { CONTDA }\end{array}$ & SLOP30_30M & $\begin{array}{c}\text { Non- } \\
\text { exceedance } \\
\text { percentile1 for } \\
\text { SLOP30_30M }\end{array}$ & ET0306MOD & $\begin{array}{c}\text { Non- } \\
\text { exceedance } \\
\text { percentile } \\
\text { ET0306MOD }\end{array}$ \\
\hline 376 & 06177250 & $\begin{array}{l}\text { Tusler Creek } \\
\text { tributary near } \\
\text { Brockway, } \\
\text { Montana }\end{array}$ & 47.2978 & -105.6785 & CSG & 18 & 3.09 & 41.1 & 0.0 & 1.1 & 1.077 & 54.4 \\
\hline 377 & 06177300 & $\begin{array}{c}\text { Redwater River } \\
\text { tributary near } \\
\text { Brockway, } \\
\text { Montana }\end{array}$ & 47.3463 & -105.6850 & CSG & 18 & 0.26 & 2.2 & 0.0 & 1.1 & 1.040 & 42.2 \\
\hline 378 & 06177350 & $\begin{array}{l}\text { South Fork Dry } \\
\text { Ash Creek } \\
\text { near Circle, } \\
\text { Montana }\end{array}$ & 47.2954 & -105.5973 & $\mathrm{CSG}$ & 19 & 6.76 & 55.6 & 0.0 & 1.1 & 1.130 & 74.4 \\
\hline 379 & 06177400 & $\begin{array}{l}\text { McCune Creek } \\
\text { near Circle, } \\
\text { Montana }\end{array}$ & 47.3498 & -105.5860 & $\begin{array}{r}\text { CONT, } \\
\text { CSG }\end{array}$ & 24 & 29.7 & 73.3 & 3.2 & 86.7 & 1.099 & 62.2 \\
\hline 382 & 06177720 & $\begin{array}{l}\text { West Fork } \\
\text { Sullivan Creek } \\
\text { near Richey, } \\
\text { Montana }\end{array}$ & 47.5322 & -105.2351 & CSG & 20 & 14.7 & 70.0 & 0.4 & 70.0 & 1.127 & 73.3 \\
\hline 385 & 06177825 & $\begin{array}{l}\text { Redwater River } \\
\text { near Vida, } \\
\text { Montana }\end{array}$ & 47.9022 & -105.2128 & CONT & 13 & 1,982 & 98.9 & 0.3 & 64.4 & 1.123 & 71.1 \\
\hline 394 & 06181200 & $\begin{array}{l}\text { Missouri River } \\
\text { tributary No. } 2 \\
\text { near Brockton, } \\
\text { Montana }\end{array}$ & 48.1520 & -104.9019 & CSG & 15 & 0.69 & 10.0 & 2.7 & 84.4 & 1.052 & 47.8 \\
\hline 408 & 06185100 & $\begin{array}{l}\text { Big Muddy Creek } \\
\text { tributary near } \\
\text { Culbertson, } \\
\text { Montana }\end{array}$ & 48.1928 & -104.6979 & $\mathrm{CSG}$ & 15 & 7.24 & 57.8 & 0.0 & 1.1 & 1.135 & 75.6 \\
\hline 410 & 06185200 & $\begin{array}{l}\text { Missouri River } \\
\text { tributary } \\
\text { No. } 3 \text { near } \\
\text { Culbertson, } \\
\text { Montana }\end{array}$ & 48.1042 & -104.5158 & $\mathrm{CSG}$ & 15 & 1.25 & 24.4 & 7.1 & 93.3 & 1.073 & 53.3 \\
\hline
\end{tabular}


Table 21. Information on discontinued streamgages in the East-Central Plains hydrologic region that might be candidates for reactivation to improve the streamgage network.-Continued

[NAD 83, North American Datum of 1983; $n$, total number of years of peak-flow records; CONTDA, contributing drainage area, in square miles; SLOP30_30M, percentage of basin in slopes greater than or equal to 30 percent; $E T 0306 \mathrm{MOD}$, spring mean monthly evapotranspiration, in inches per month; CSG, crest-stage gage; CONT, continuous streamgage]

\begin{tabular}{|c|c|c|c|c|c|c|c|c|c|c|c|c|}
\hline $\begin{array}{l}\text { Map } \\
\text { number } \\
\text { (fig. 1) }\end{array}$ & $\begin{array}{c}\text { Station } \\
\text { identification } \\
\text { number }\end{array}$ & Station name & $\begin{array}{l}\text { Latitude, } \\
\text { in decimal } \\
\text { degrees } \\
\text { (NAD 83) }\end{array}$ & $\begin{array}{c}\text { Longitude, } \\
\text { in decimal } \\
\text { degrees } \\
\text { (NAD 83) }\end{array}$ & $\begin{array}{c}\text { Type of } \\
\text { streamgage }\end{array}$ & $n$ & CONTDA & $\begin{array}{l}\text { Non- } \\
\text { exceedance } \\
\text { percentile }{ }^{1} \text { for } \\
\text { CONTDA }\end{array}$ & SLOP30_30M & $\begin{array}{c}\text { Non- } \\
\text { exceedance } \\
\text { percentile } \\
\text { SLOP30_30M }\end{array}$ & ET0306MOD & $\begin{array}{c}\text { Non- } \\
\text { exceedance } \\
\text { percentile }{ }^{1} \text { for } \\
\text { ET0306MOD }\end{array}$ \\
\hline 411 & 06185300 & $\begin{array}{l}\text { Missouri River } \\
\text { tributary No. } 4 \\
\text { near Bainville, } \\
\text { Montana }\end{array}$ & 48.1419 & -104.3528 & CSG & 15 & 11.0 & 65.6 & 0.0 & 42.2 & 1.299 & 96.7 \\
\hline 489 & 06294800 & $\begin{array}{l}\text { Unknown Creek } \\
\text { near Bighorn, } \\
\text { Montana }\end{array}$ & 46.1970 & -107.4092 & $\mathrm{CSG}$ & 17 & 14.6 & 68.9 & 13.1 & 97.8 & 1.114 & 68.9 \\
\hline 491 & 06294900 & $\begin{array}{l}\text { Middle Fork } \\
\text { Froze to Death } \\
\text { Creek tributary } \\
\text { near Ingomar, } \\
\text { Montana }\end{array}$ & 46.5813 & -107.4005 & CSG & 15 & 1.37 & 25.6 & 0.5 & 75.6 & 0.950 & 12.2 \\
\hline 494 & 06294960 & $\begin{array}{l}\text { Anderson Creek } \\
\text { at Vananda, } \\
\text { Montana }\end{array}$ & 46.3930 & -107.0081 & CSG & 13 & 5.70 & 53.3 & 0.0 & 1.1 & 0.975 & 16.7 \\
\hline 499 & 06295050 & $\begin{array}{l}\text { Little Porcupine } \\
\text { Creek near } \\
\text { Forsyth, } \\
\text { Montana }\end{array}$ & 46.3044 & -106.5751 & CSG & 20 & 611 & 92.2 & 0.2 & 61.1 & 0.913 & 5.6 \\
\hline 535 & 06309020 & $\begin{array}{l}\text { Rock Springs } \\
\text { Creek tribu- } \\
\text { tary at Rock } \\
\text { Springs, } \\
\text { Montana }\end{array}$ & 46.8222 & -106.2544 & $\mathrm{CSG}$ & 17 & 1.16 & 22.2 & 0.0 & 1.1 & 1.018 & 33.3 \\
\hline 536 & 06309040 & $\begin{array}{l}\text { Dry House Creek } \\
\text { near Angela, } \\
\text { Montana }\end{array}$ & 46.6872 & -106.1748 & CSG & 16 & 36.7 & 75.6 & 0.0 & 1.1 & 1.005 & 28.9 \\
\hline 538 & 06309075 & $\begin{array}{l}\text { Sunday Creek } \\
\text { near Miles } \\
\text { City, Montana }\end{array}$ & 46.4727 & -105.8435 & CONT & 10 & 717 & 95.6 & 0.1 & 55.6 & 0.951 & 13.3 \\
\hline 554 & 06326550 & $\begin{array}{l}\text { Cherry Creek } \\
\text { tributary near } \\
\text { Terry, Montana }\end{array}$ & 46.8551 & -105.3412 & CSG & 19 & 2.60 & 38.9 & 10.5 & 96.7 & 0.931 & 6.7 \\
\hline
\end{tabular}


Table 21. Information on discontinued streamgages in the East-Central Plains hydrologic region that might be candidates for reactivation to improve the streamgage

network.-Continued

[NAD 83, North American Datum of $1983 ; n$, total number of years of peak-flow records; CONTDA, contributing drainage area, in square miles; SLOP30 $30 M$, percentage of basin in slopes greater than or equal to 30 percent; $E T 0306 M O D$, spring mean monthly evapotranspiration, in inches per month; CSG, crest-stage gage; CONT, continuous streamgage]

\begin{tabular}{|c|c|c|c|c|c|c|c|c|c|c|c|c|}
\hline $\begin{array}{l}\text { Map } \\
\text { number } \\
\text { (fig. 1) }\end{array}$ & $\begin{array}{c}\text { Station } \\
\text { identification } \\
\text { number }\end{array}$ & Station name & $\begin{array}{l}\text { Latitude, } \\
\text { in decimal } \\
\text { degrees } \\
\text { (NAD 83) }\end{array}$ & $\begin{array}{c}\text { Longitude, } \\
\text { in decimal } \\
\text { degrees } \\
\text { (NAD 83) }\end{array}$ & $\begin{array}{c}\text { Type of } \\
\text { streamgage }\end{array}$ & $n$ & CONTDA & $\begin{array}{l}\text { Non- } \\
\text { exceedance } \\
\text { percentile }{ }^{1} \text { for } \\
\text { CONTDA }\end{array}$ & SLOP30_30M & $\begin{array}{c}\text { Non- } \\
\text { exceedance } \\
\text { percentile }{ }^{1} \text { for } \\
\text { SLOP30_30M }\end{array}$ & ET0306MOD & $\begin{array}{c}\text { Non- } \\
\text { exceedance } \\
\text { percentile } \\
\text { ET0306MOD }\end{array}$ \\
\hline 560 & 06326900 & $\begin{array}{l}\text { Yellowstone } \\
\text { River tribu- } \\
\text { tary No. } 4 \\
\text { near Fallon, } \\
\text { Montana }\end{array}$ & 46.8658 & -105.1018 & CSG & 15 & 0.80 & 13.3 & 0.0 & 1.1 & 1.012 & 30.0 \\
\hline 571 & 06328400 & $\begin{array}{l}\text { Thirteenmile } \\
\text { Creek } \\
\text { tributary near } \\
\text { Bloomfield, } \\
\text { Montana }\end{array}$ & 47.4128 & -104.8316 & $\mathrm{CSG}$ & 19 & 0.66 & 7.8 & 0.0 & 1.1 & 1.150 & 81.1 \\
\hline 572 & 06328700 & $\begin{array}{l}\text { Linden Creek } \\
\text { at Intake, } \\
\text { Montana }\end{array}$ & 47.2974 & -104.5258 & $\mathrm{CSG}$ & 17 & 3.97 & 48.9 & 0.0 & 1.1 & 1.151 & 83.3 \\
\hline 573 & 06328800 & $\begin{array}{c}\text { Indian Creek } \\
\text { at Intake, } \\
\text { Montana }\end{array}$ & 47.2916 & -104.5405 & $\mathrm{CSG}$ & 16 & 0.26 & 2.2 & 0.0 & 1.1 & 1.103 & 63.3 \\
\hline 574 & 06328900 & $\begin{array}{l}\text { War Dance Creek } \\
\text { near Intake, } \\
\text { Montana }\end{array}$ & 47.3270 & -104.4883 & $\mathrm{CSG}$ & 17 & 3.74 & 46.7 & 0.1 & 53.3 & 1.143 & 77.8 \\
\hline 575 & 06329200 & $\begin{array}{l}\text { Burns Creek } \\
\text { near Savage, } \\
\text { Montana }\end{array}$ & 47.3723 & -104.4300 & CONT & 21 & 234 & 84.4 & 1.6 & 77.8 & 1.169 & 86.7 \\
\hline 578 & 06329510 & $\begin{array}{l}\text { Fox Creek } \\
\text { tributary near } \\
\text { Lambert, } \\
\text { Montana }\end{array}$ & 47.6493 & -104.6149 & CSG & 24 & 5.16 & 52.2 & 0.2 & 60.0 & 1.236 & 94.4 \\
\hline
\end{tabular}

${ }^{1}$ The nonexceedance percentile for the basin or climatic variable value was calculated in relation to the values for all streamgages included in the regional regression analyses for the indicated hydrologic region. 

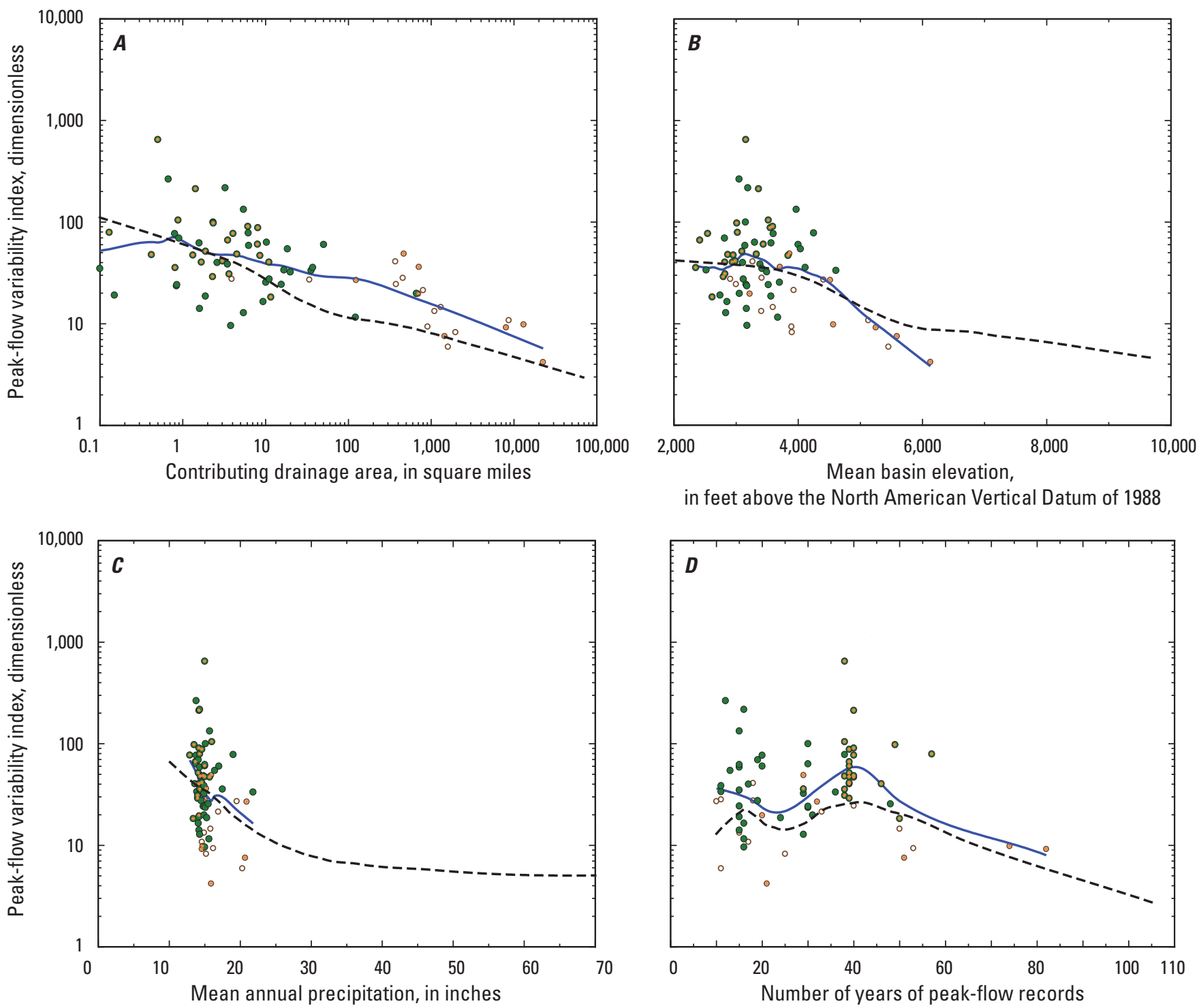

\section{EXPLANATION}

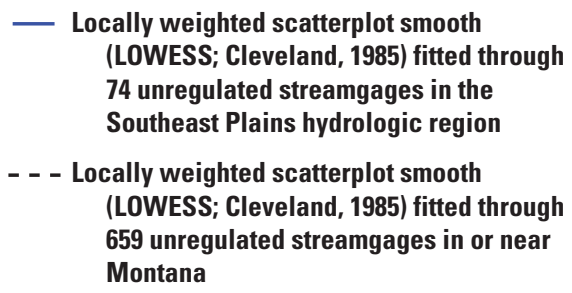

Crest-stage streamgage

- Continuous streamgage

Interior dot denotes active streamgage in water year 2017

Figure 21. Relations between peak-flow variability index and contributing drainage area, mean basin elevation, mean annual precipitation, and years of peak-flow records for 74 unregulated streamgages in the Southeast Plains hydrologic region. $A$, Peak-flow variability and contributing drainage area relations. $B$, Peak-flow variability and mean basin elevation relations. $C$, Peak-flow variability and mean annual precipitation relations. $D$, Peak-flow variability and years of peak-flow records relations. 


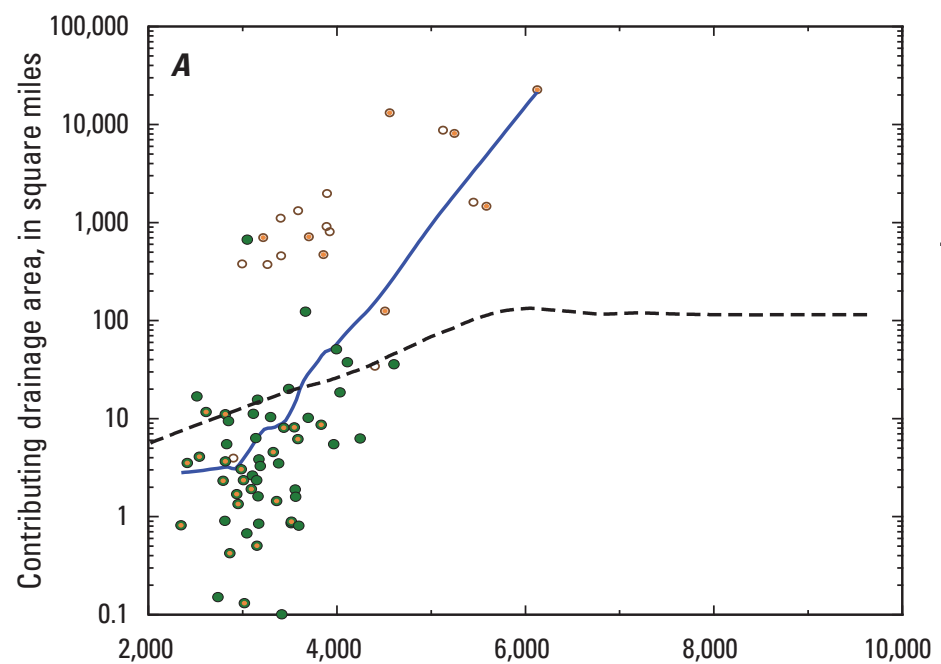

\section{EXPLANATION}

Locally weighted scatterplot smooth (LOWESS; Cleveland, 1985) fitted through

74 unregulated streamgages in the

Southeast Plains hydrologic region

- - - Locally weighted scatterplot smooth (LOWESS; Cleveland, 1985) fitted through 659 unregulated streamgages in or near Montana

- Crest-stage streamgage

- Continuous streamgage

- Interior dot denotes active streamgage in water year 2017

Mean basin elevation, in feet above the North American Vertical Datum of 1988
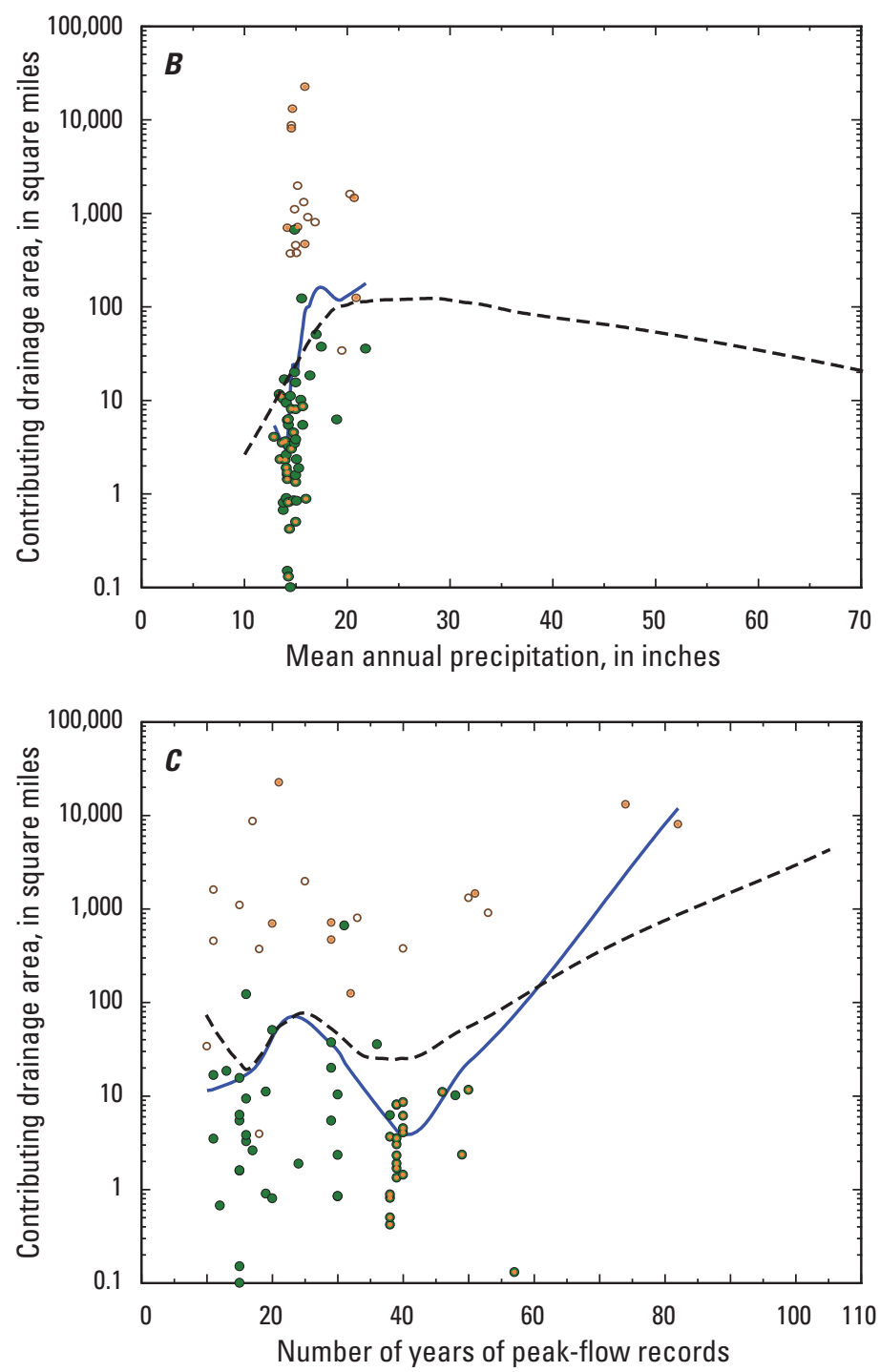

Figure 22. Relations between contributing drainage area and mean basin elevation, mean annual precipitation, and years of peak-flow records for 74 unregulated streamgages in the Southeast Plains hydrologic region. $A$, Contributing drainage area and mean basin elevation relations. $B$, Contributing drainage area and mean annual precipitation relations. $C$, Contributing drainage area and years of peak-flow records relations. 


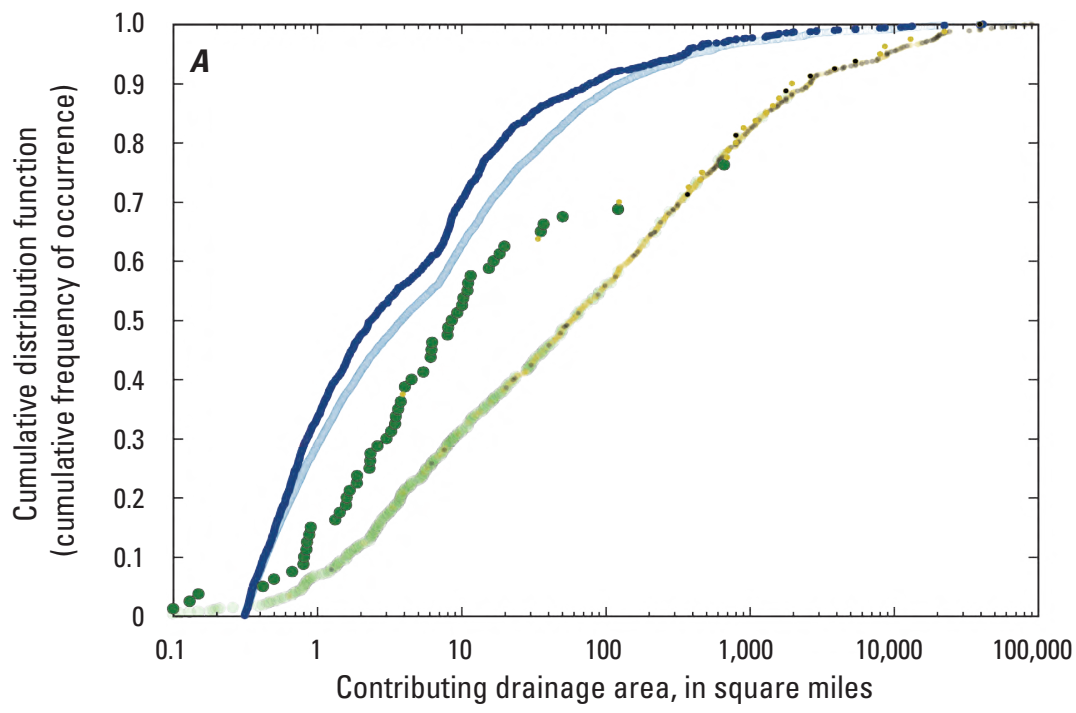

\section{EXPLANATION}

- Road and stream intersection in the Southeast Plains hydrologic region

One of 12,639 road and stream intersections in Montana, as shown in figure 5-0pen symbols appear as solid symbols because of the high data density

Regulated and unregulated streamgages in the Southeast Plains hydrologic region

- Crest-stage streamgage

Unregulated continuous streamgage

- Regulated continuous streamgage

Regulated and unregulated streamgages in or near Montana, as shown in figure 5

Crest-stage streamgage in or near Montana Unregulated streamgages in or near Montana

Regulated streamgages in or near Montana

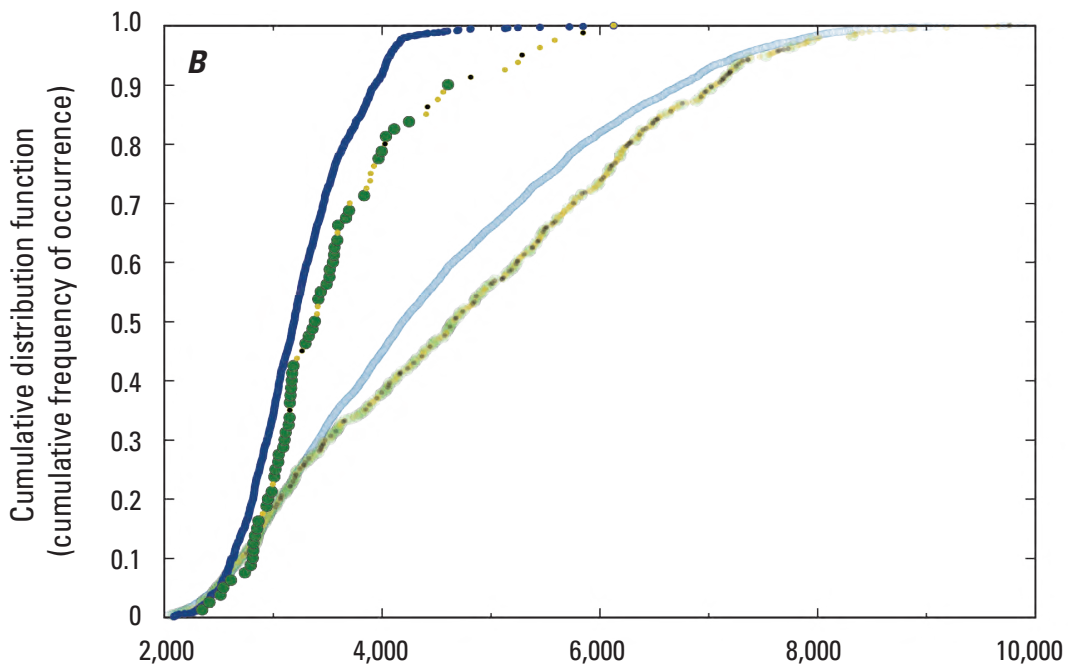

Mean basin elevation, in feet above the North American Vertical Datum of 1988

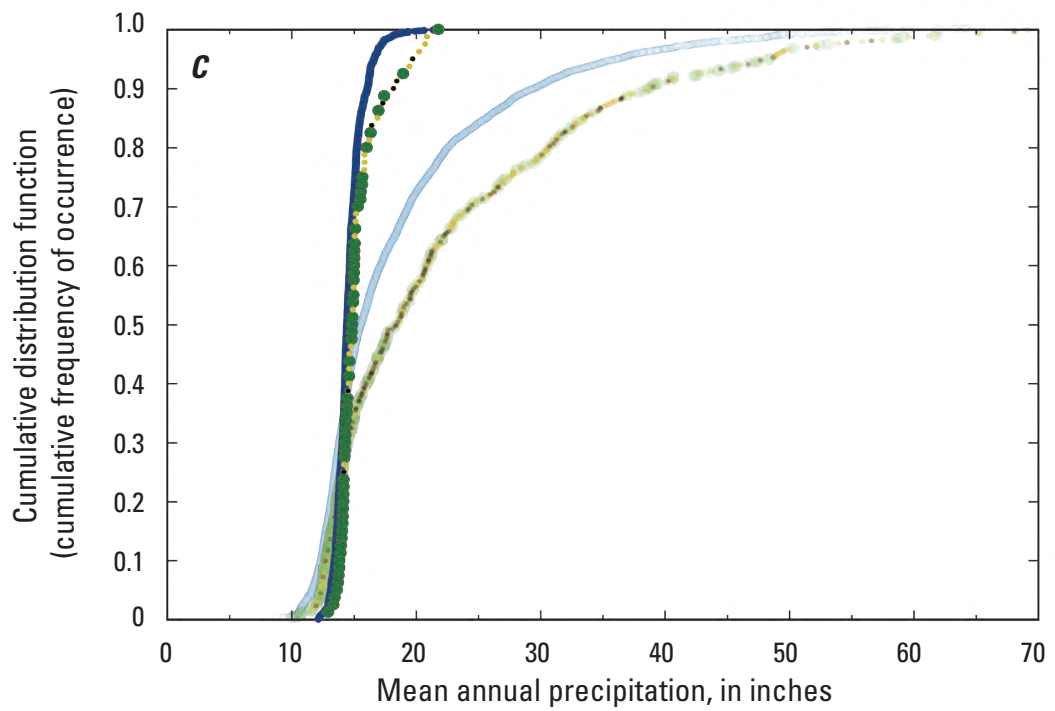

Figure 23. Cumulative distribution functions of selected drainage-basin characteristics for 1,371 road and stream intersections and for 80 streamgages (regulated and unregulated) in the Southeast Plains hydrologic region. $A$, Contributing drainage area relations. $B$, Mean basin elevation relations. $C$, Mean annual precipitation relations. 
There are substantial differences between the CDFs of road and stream intersections for the Southeast Plains hydrologic region relative to the CDFs of road and stream intersections for all of Montana (fig. 23C). With respect to mean annual precipitation, the pattern of the streamgage CDF reasonably represents the road and stream intersection CDF but with small underrepresentation in a small range of mean annual precipitation from about 15 to 16 inches.

The explanatory variables for the Southeast Plains hydrologic region RREs are CONTDA, FOREST, and ET0306MOD (table 6). The 1-percent AEP RRE for the Southeast Plains hydrologic region has an SEP of 71.1 percent, which is higher than the area-weighted mean SEP for all hydrologic regions in Montana (63.3 percent; table 6). For the 1-percent AEP regression for the Southeast Plains hydrologic region, 5.9 percent of the streamgages have significant leverage and 14.7 percent of the streamgages have significant influence (table 7). The significant leverage percentage is somewhat smaller than the significant leverage percentage for all of the streamgages in Montana used in the regional regression analyses ( 8.2 percent; table 7) and the significant influence percentage is somewhat larger than the significant influence percentage for all of the streamgages in Montana used in the regional regression analyses (10.4 percent; table 7).

Information on streamgages in the Southeast Plains hydrologic region with significant leverage and influence is presented in table 22 . Three of the five significant leverage streamgages have high ET0306MOD values (nonexceedance percentiles greater than about 96 percent). Two of the five significant leverage streamgages have small CONTDA values (nonexceedance percentiles less than about 6 percent). The 15 streamgages with significant influence vary with respect to the residuals for the 1-percent AEP RRE; nine of the streamgages have negative residuals, and six have positive residuals. The one streamgage with both significant leverage and significant influence has a positive residual.

In general, the streamgage network in the Southeast Plains hydrologic region is considered to provide generally reasonable representation of the hydroclimatic settings of that hydrologic region. The RREs of the Southeast Plains hydrologic region are considered to be reasonably reliable. However, small basins (CONTDA less than about $20 \mathrm{mi}^{2}$ ) are more strongly represented in the Southeast Plains hydrologic region than the other hydrologic regions; greater variability in annual peak flows in small basins might contribute to the large SEP (71.1 percent) for the 1-percent AEP RRE for the Southeast Plains hydrologic region. Possible shortcomings of the streamgage network in the Southeast Plains hydrologic region include underrepresentation of basins with CONTDA from about 20 to $370 \mathrm{mi}^{2}$, mean elevation from about 3,600 to $4,200 \mathrm{ft}$, and (or) mean annual precipitation from about 15 to 16 inches. Future improvements to the streamgage network in the Southeast Plains hydrologic region might include discontinuing some CSGs on basins with drainage areas less than about $20 \mathrm{mi}^{2}$ and reactivating discontinued streamgages as CSGs on drainage basins within the specified underrepresented characteristics. Establishing new CSGs on basins with drainage areas from about 20 to $370 \mathrm{mi}^{2}$ might also be warranted to appropriately distribute CONTDA representation in the streamgage network. In addition to possibly providing better representation of the road and stream intersections network, redistributing some CSGs from smaller to larger basins might be beneficial for regional regression analyses. Because larger basins integrate hydroclimatic characteristics of multiple smaller basins, appropriate representation of larger basins might assist in developing efficient regression relations. Information on discontinued streamgages in the Southeast Plains hydrologic region that might be candidates for reactivation to improve the streamgage network is presented in table 23.

\section{Peak-Flow Variability, Peak-Flow Informational Needs, and Consideration of Regional Regression Analyses in the Upper Yellowstone-Central Mountain Hydrologic Region}

The Upper Yellowstone-Central Mountain hydrologic region has an area of 23,003 $\mathrm{mi}^{2}$ (table 1), which ranks second largest among the eight hydrologic regions. Level III ecoregions (table 2) represented in the Upper Yellowstone-Central Mountain hydrologic region include the Middle Rockies (35.8 percent), Northwestern Glaciated Plains (0.1 percent), Northwestern Great Plains (62.2 percent), and Wyoming Basin (1.9 percent). The 2,166 road and stream intersections in the Upper Yellowstone-Central Mountain hydrologic region (tables 4 and 5) represent a density of 0.094 road and stream intersection per $\mathrm{mi}^{2}$, which ranks fourth among the hydrologic regions. The 113 streamgages (both regulated and unregulated; table 4 and 5) represent an areal density of 0.00491 streamgage per $\mathrm{mi}^{2}$ (ranking fourth among hydrologic regions) and a density of 0.05217 streamgage per road and stream intersection (ranking sixth among hydrologic regions).

Relations between $P F V I$ and contributing drainage area, mean basin elevation, mean annual precipitation, and years of peak-flow records for 108 unregulated streamgages in the Upper Yellowstone-Central Mountain hydrologic region (table 3) are presented in figure 24. For the 108 unregulated streamgages, $P F V I$ generally monotonically decreases with increasing drainage area (fig. 24A). Intuitively, highly variable small-scale hydroclimatic processes are integrated with increasing drainage area such that variability in many hydrologic characteristics is reduced. For drainage areas smaller than about $50 \mathrm{mi}^{2}$, variability in $P F V I$ is large and the LOWESS line for the streamgages in the Upper YellowstoneCentral Mountain hydrologic region is above the LOWESS line for all unregulated streamgages in Montana. For drainage areas larger than about $50 \mathrm{mi}^{2}$, variability in $P F V I$ is moderate and the LOWESS line for the streamgages in the Upper Yellowstone-Central Mountain hydrologic region is below the 
LOWESS line for all unregulated streamgages in Montana. PFVI also decreases with increasing elevation (fig. 24B), precipitation (fig. 24C), and years of record (fig. 24D). For the relations between PFVI and elevation (fig. 24B) and precipitation (fig. 24C), the LOWESS lines for the Upper YellowstoneCentral Mountain hydrologic region are above the LOWESS lines for all unregulated streamgages in Montana at elevations less than about $6,000 \mathrm{ft}$ and precipitation less than about 20 inches.

Relations between contributing drainage area and mean basin elevation, mean annual precipitation, and years of peakflow records for the unregulated streamgages are presented in figure 25. Streamgages with greater than about 60 years of record are predominantly located on streams with contributing drainage areas greater than about $100 \mathrm{mi}^{2}$ (fig. 25C), which likely strongly contributes to the $P F V I$ and years of record relations (fig. 24D).

The median PFVI value for streamgages in the Upper Yellowstone-Central Mountain hydrologic region (14.48, table 3 ) is somewhat less than the median for all unregulated streamgages in Montana (18.26, table 3) and ranks as the fifth largest median PFVI among the eight hydrologic regions. A major factor contributing to low peak-flow variability in the Upper Yellowstone-Central Mountain hydrologic region might be the dominance of snowmelt runoff in the annual hydrograph of many of the streamgages. For unregulated streamgages in the Upper Yellowstone-Central Mountain hydrologic region, fall and winter (October-February) precipitation accounts for 24.1 percent of annual precipitation (table 8), which can result in large accumulated snowpacks (Sando and McCarthy, 2018) that contribute to streamflows during the typical snowmelt runoff period of May through mid-July. May-June precipitation accounts for about 32.9 percent of annual precipitation (table 8), which ranks fifth among the hydrologic regions, and July-August precipitation accounts for 17.5 percent of annual precipitation, which ranks sixth among the eight hydrologic regions. In the Upper Yellowstone-Central Mountain hydrologic region, annual peak flows predominantly are in May and June (fig. 2 of Sando, R., and others, 2018). Dominance of snowmelt in the annual hydrograph tends to provide temporal integration of a substantial part of the annual precipitation inputs and contributes to the low PFVIs for streamgages in the Upper Yellowstone-Central Mountain hydrologic region.

About 3.9 percent of the streamgages in the Upper Yellowstone-Central Mountain hydrologic region are considered to have mixed-population characteristics (table 1) that result in a small number of unusually large peak flows that are substantially larger than the main body of peak flows. Mixedpopulation peak-flow datasets are not a substantial consideration in the Upper Yellowstone-Central Mountain hydrologic region. However, possible future advances in understanding of mixed-population characteristics might result in identification of more mixed-population peak-flow datasets in the Upper Yellowstone-Central Mountain hydrologic region.
The CDFs of selected basin characteristics (drainage area, mean basin elevation, and mean annual precipitation) for the road and stream intersections and for the streamgages in the Upper Yellowstone-Central Mountain hydrologic region are shown in figure 26. With respect to drainage area, the CDF of road and stream intersections for the Upper YellowstoneCentral Mountain hydrologic region generally is similar to the CDF of road and stream intersections for all of Montana (fig. 26A). In the Upper Yellowstone-Central Mountain hydrologic region, the $\mathrm{CDF}$ of streamgages diverges from the $\mathrm{CDF}$ of road and stream intersections in the range of drainage areas less than about $32 \mathrm{mi}^{2}$. In the range of drainage areas less than about $10 \mathrm{mi}^{2}$, the CDF of streamgages in the Upper Yellowstone-Central Mountain hydrologic region is similar to the CDF of streamgages for all of Montana; thus, streamgages with drainage areas in that range are not considered to be underrepresented in the Upper Yellowstone-Central Mountain hydrologic region. In the range of drainage areas between about 10 and $32 \mathrm{mi}^{2}$, the CDF of streamgages in the Upper Yellowstone-Central Mountain hydrologic region diverges from the $\mathrm{CDF}$ of road and stream intersections and also diverges from the CDF of streamgages for all of Montana; thus, streamgages with drainage areas in that range are considered to be underrepresented in the Upper Yellowstone-Central Mountain hydrologic region.

Mean basin elevation for road and stream intersections in the Upper Yellowstone-Central Mountain hydrologic region ranges from 2,839 to 9,890 ft (Dutton and others, 2021) with a median of 4,889 ft (table 4), which generally are similar to the range (1,951-9,974 ft; Dutton and others, 2021) and median $(4,173 \mathrm{ft}$; table 4) for all of Montana. However, the Upper Yellowstone-Central Mountain hydrologic region has a somewhat lower proportion of road and stream intersections less than about 4,000 ft than Montana as a whole (fig. 26B). With respect to mean basin elevation, the pattern of the streamgage $\mathrm{CDF}$ reasonably represents the road and stream intersection $\mathrm{CDF}$ but with some underrepresentation at elevations less than about 5,100 ft.

The Upper Yellowstone-Central Mountain hydrologic region is somewhat wetter than Montana as a whole. Mean annual precipitation for road and stream intersections in the Upper Yellowstone-Central Mountain hydrologic region ranges from 8.4 to 45.6 inches (Dutton and others, 2021) with a median of 17.7 inches (table 5). The range for the Upper Yellowstone-Central Mountain hydrologic region is smaller than for all of Montana (8.4-91.3 ft; Dutton and others, 2021) and the median for the Upper Yellowstone-Central Mountain hydrologic region is somewhat larger than for all of Montana (15.7 inches; table 5). The Upper Yellowstone-Central Mountain hydrologic region has a somewhat lower proportion of road and stream intersections with mean annual precipitation less than about 15 inches than Montana as a whole (fig. 26C). With respect to mean annual precipitation, the pattern of the streamgage $\mathrm{CDF}$ reasonably represents the road and stream intersection CDF but the CDF of streamgages slightly 
Table 22. Information on streamgages in the Southeast Plains hydrologic region with significant leverage and influence in the Montana regional regression analyses (Sando, R., and others, 2018).

[ID, identification; NAD 83, North American Datum of 1983; $n$, total number of years of peak-flow records; CONTDA, contributing drainage area, in square miles; FOREST, percentage of basin in forest; ET0306MOD, spring mean monthly evapotranspiration, in inches per month; AEP, annual exceedance probability; CONT, continuous streamgage; CSG, crest-stage gage]

\begin{tabular}{|c|c|c|c|c|c|c|c|}
\hline $\begin{array}{c}\text { Map } \\
\text { number } \\
\text { (fig. 1) }\end{array}$ & $\begin{array}{l}\text { Streamgage } \\
\text { ID number }\end{array}$ & Streamgage name & $\begin{array}{l}\text { Latitude, } \\
\text { in decimal } \\
\text { degrees } \\
\text { (NAD 83) }\end{array}$ & $\begin{array}{c}\text { Longitude, } \\
\text { in decimal } \\
\text { degrees } \\
\text { (NAD 83) }\end{array}$ & $\begin{array}{c}\text { Type of } \\
\text { streamgage }\end{array}$ & $\begin{array}{c}\text { Status of } \\
\text { streamgage in } \\
\text { water year } 2017\end{array}$ & $n$ \\
\hline \multicolumn{8}{|c|}{ Streamgages with significant leverage } \\
\hline 500 & 06295100 & Rosebud Creek near Kirby, Montana & 45.2457 & -106.9679 & CONT, CSG & Discontinued & 36 \\
\hline 501 & 06295113 & $\begin{array}{l}\text { Rosebud Creek at reservation bound- } \\
\text { ary, near Kirby, Montana }\end{array}$ & 45.3612 & -106.9904 & CONT & Active & 35 \\
\hline 509 & ${ }^{2} 06306300$ & $\begin{array}{l}\text { Tongue River at State line, near } \\
\text { Decker, Montana }\end{array}$ & 45.0091 & -106.8359 & CONT & Active & 57 \\
\hline 528 & 06308200 & $\begin{array}{l}\text { Basin Creek tributary near Volborg, } \\
\text { Montana }\end{array}$ & 45.8856 & -105.6824 & CSG & Active & 62 \\
\hline 569 & 06327790 & $\begin{array}{l}\text { Krug Creek tributary No. } 2 \text { near } \\
\text { Wibaux, Montana }\end{array}$ & 47.0083 & -104.3060 & CSG & Active & 43 \\
\hline \multicolumn{8}{|c|}{ Streamgages with significant influence } \\
\hline 469 & 06217800 & $\begin{array}{l}\text { Yellowstone River tributary No. } 2 \text { near } \\
\text { Pompeys Pillar, Montana }\end{array}$ & 46.0418 & -107.7968 & CSG & Discontinued & 12 \\
\hline 485 & 06294400 & Andresen Coulee near Custer, Montana & 46.0651 & -107.5429 & CSG & Active & 54 \\
\hline 502 & 06295130 & $\begin{array}{l}\text { Rosebud Creek tributary near Busby, } \\
\text { Montana }\end{array}$ & 45.5801 & -106.8690 & CSG & Discontinued & 15 \\
\hline 505 & 06296003 & $\begin{array}{l}\text { Rosebud Creek at mouth, near } \\
\text { Rosebud, Montana }\end{array}$ & 46.2646 & -106.4752 & CONT & Discontinued & 33 \\
\hline 509 & ${ }^{2} 06306300$ & $\begin{array}{l}\text { Tongue River at State line, near } \\
\text { Decker, Montana }\end{array}$ & 45.0091 & -106.8359 & CONT & Active & 57 \\
\hline 522 & 06307740 & Otter Creek at Ashland, Montana & 45.5884 & -106.2551 & CONT & Active & 34 \\
\hline 526 & 06307930 & Jack Creek near Volborg, Montana & 46.0819 & -105.8528 & CSG & Discontinued & 29 \\
\hline 540 & 06309080 & Deep Creek near Kinsey, Montana & 46.5568 & -105.6207 & CSG & Active & 55 \\
\hline 547 & 06325500 & $\begin{array}{l}\text { Little Powder River near Broadus, } \\
\text { Montana }\end{array}$ & 45.3898 & -105.3054 & CONT & Discontinued & 25 \\
\hline 549 & 06325950 & Cut Coulee near Mizpah, Montana & 46.1439 & -105.1687 & CSG & Active & 44 \\
\hline 555 & 06326580 & $\begin{array}{l}\text { Lame Jones Creek tributary near } \\
\text { Willard, Montana }\end{array}$ & 46.1941 & -104.5522 & CSG & Active & 43 \\
\hline 568 & 06327720 & $\begin{array}{l}\text { Griffith Creek tributary near Glendive, } \\
\text { Montana }\end{array}$ & 47.1055 & -104.5973 & CSG & Active & 44 \\
\hline 580 & 06333850 & North Creek near Alzada, Montana & 45.0613 & -104.5293 & CONT, CSG & Discontinued & 24 \\
\hline 584 & 06334330 & $\begin{array}{l}\text { Little Missouri River tributary near } \\
\text { Albion, Montana }\end{array}$ & 45.2106 & -104.2618 & CSG & Active & 44 \\
\hline 591 & 06336500 & Beaver Creek at Wibaux, Montana & 46.9899 & -104.1838 & CONT & Discontinued & 40 \\
\hline
\end{tabular}

${ }^{1}$ The nonexceedance percentile for the basin or climatic variable value was calculated in relation to the values for all streamgages included in the regional regression analyses for the indicated hydrologic region.

${ }^{2}$ Streamgages having both significant leverage and significant influence. 


\begin{tabular}{|c|c|c|c|c|c|c|c|c|}
\hline \multirow{2}{*}{ CONTDA } & \multirow{2}{*}{$\begin{array}{c}\text { Nonexceedance } \\
\text { percentile }{ }^{1} \text { for } \\
\text { CONTDA }\end{array}$} & \multirow{2}{*}{ FOREST } & \multirow{2}{*}{$\begin{array}{c}\text { Nonexceedance } \\
\text { percentile }^{1} \text { for } \\
\text { FOREST }\end{array}$} & \multirow{2}{*}{ ET0306MOD } & \multirow{2}{*}{$\begin{array}{c}\text { Nonexceedance } \\
\text { percentile }{ }^{1} \text { for } \\
\text { ET0306MOD }\end{array}$} & \multicolumn{3}{|c|}{$\begin{array}{l}\text { Regression residuals for the } \\
\text { specified AEP regression analyses }\end{array}$} \\
\hline & & & & & & $\begin{array}{l}\text { 10-percent } \\
\text { AEP }\end{array}$ & $\begin{array}{l}\text { 4-percent } \\
\text { AEP }\end{array}$ & $\begin{array}{l}\text { 1-percent } \\
\text { AEP }\end{array}$ \\
\hline \multicolumn{9}{|c|}{ Streamgages with significant leverage } \\
\hline 35.5 & 76.5 & 5.59 & 47.1 & 1.58 & 95.6 & 0.073 & 0.048 & 0.014 \\
\hline 124 & 82.4 & 20.99 & 82.4 & 1.67 & 100.0 & -0.098 & -0.071 & 0.011 \\
\hline 1,451 & 98.5 & 26.29 & 89.7 & 1.62 & 98.5 & 0.698 & 0.575 & 0.452 \\
\hline 0.13 & 2.9 & 19.07 & 77.9 & 1.08 & 23.5 & 0.190 & 0.132 & 0.100 \\
\hline 0.42 & 5.9 & 17.25 & 72.1 & 1.31 & 83.8 & 0.282 & 0.106 & -0.100 \\
\hline 2.34 & 32.4 & 14.87 & 69.1 & 1.02 & 7.4 & -0.602 & -0.581 & -0.497 \\
\hline 0.10 & 1.5 & 0.00 & 1.5 & 1.24 & 61.8 & -0.352 & -0.479 & -0.645 \\
\hline 1,307 & 97.1 & 21.88 & 83.8 & 1.30 & 82.4 & -0.386 & -0.429 & -0.432 \\
\hline 1,451 & 98.5 & 26.29 & 89.7 & 1.62 & 98.5 & 0.698 & 0.575 & 0.452 \\
\hline 710 & 92.6 & 24.39 & 86.8 & 1.26 & 72.1 & -0.909 & -0.899 & -0.853 \\
\hline 5.43 & 48.5 & 4.69 & 44.1 & 0.97 & 2.9 & 0.008 & -0.209 & -0.466 \\
\hline 3.50 & 39.7 & 9.58 & 58.8 & 1.06 & 14.7 & 0.314 & 0.442 & 0.628 \\
\hline 1.88 & 26.5 & 0.00 & 1.5 & 1.15 & 38.2 & 0.716 & 0.659 & 0.586 \\
\hline 1.43 & 20.6 & 0.00 & 1.5 & 1.27 & 73.5 & -0.579 & -0.435 & -0.252 \\
\hline 376 & 85.3 & 0.97 & 29.4 & 1.36 & 88.2 & 0.413 & 0.445 & 0.458 \\
\hline
\end{tabular}


[NAD 83, North American Datum of 1983; $n$, total number of years of peak-flow records; CONTDA, contributing drainage area, in square miles; FOREST, percentage of basin in forest; ET0306MOD, spring mean monthly evapotranspiration, in inches per month; CSG, crest-stage gage; CONT, continuous streamgage]

\begin{tabular}{|c|c|c|c|c|c|c|c|c|c|c|c|c|}
\hline $\begin{array}{l}\text { Map } \\
\text { number } \\
\text { (fig. 1) }\end{array}$ & $\begin{array}{c}\text { Station } \\
\text { identification } \\
\text { number }\end{array}$ & Station name & $\begin{array}{l}\text { Latitude, } \\
\text { in decimal } \\
\text { degrees } \\
\text { (NAD 83) }\end{array}$ & $\begin{array}{l}\text { Longitude, } \\
\text { in decimal } \\
\text { degrees } \\
\text { (NAD 83) }\end{array}$ & $\begin{array}{c}\text { Type of } \\
\text { streamgage }\end{array}$ & $n$ & $\begin{array}{l}\text { CONTDA, } \\
\text { in square } \\
\text { miles }\end{array}$ & $\begin{array}{c}\text { Non- } \\
\text { exceedance } \\
\text { percentile }{ }^{1} \\
\text { for CONTDA }\end{array}$ & FOREST & $\begin{array}{l}\text { Non- } \\
\text { exceedance } \\
\text { percentile }{ }^{1} \\
\text { for } \text { FOREST }\end{array}$ & ET0306MOD & $\begin{array}{c}\text { Non- } \\
\text { exceedance } \\
\text { percentile }{ }^{1} \text { for } \\
\text { ET0306MOD }\end{array}$ \\
\hline 469 & 06217800 & $\begin{array}{l}\text { Yellowstone River tributary } \\
\text { No. } 2 \text { near Pompeys Pillar, } \\
\text { Montana }\end{array}$ & 46.0418 & -107.7968 & $\mathrm{CSG}$ & 12 & 0.67 & 8.8 & 28.4 & 92.6 & 1.03 & 11.8 \\
\hline 490 & 06294850 & $\begin{array}{l}\text { Buckingham Coulee near } \\
\text { Myers, Montana }\end{array}$ & 46.2362 & -107.2905 & CSG & 17 & 2.61 & 33.8 & 57.6 & 100.0 & 1.07 & 19.1 \\
\hline 493 & 06294940 & $\begin{array}{l}\text { Sarpy Creek near Hysham, } \\
\text { Montana }\end{array}$ & 46.2386 & -107.1371 & CONT & 11 & 454 & 86.8 & 23.4 & 85.3 & 1.21 & 51.5 \\
\hline 502 & 06295130 & $\begin{array}{l}\text { Rosebud Creek tributary near } \\
\text { Busby, Montana }\end{array}$ & 45.5801 & -106.8690 & CSG & 15 & 0.10 & 1.5 & 0.0 & 1.5 & 1.24 & 61.8 \\
\hline 503 & 06295200 & $\begin{array}{l}\text { Whitedirt Creek near Lame } \\
\text { Deer, Montana }\end{array}$ & 45.6081 & -106.7507 & CSG & 15 & 1.58 & 22.1 & 45.7 & 95.6 & 1.32 & 86.8 \\
\hline 508 & 06306100 & $\begin{array}{l}\text { Squirrel Creek near Decker, } \\
\text { Montana }\end{array}$ & 45.0515 & -106.9272 & CONT & 10 & 33.9 & 75.0 & 6.5 & 48.5 & 1.59 & 97.1 \\
\hline 514 & 06307520 & $\begin{array}{l}\text { Canyon Creek near Birney, } \\
\text { Montana }\end{array}$ & 45.2411 & -106.6762 & CSG & 20 & 50.4 & 79.4 & 18.9 & 76.5 & 1.26 & 69.1 \\
\hline 517 & 06307620 & $\begin{array}{l}\text { Tie Creek near Birney, } \\
\text { Montana }\end{array}$ & 45.4727 & -106.5307 & CSG & 13 & 18.4 & 72.1 & 46.5 & 97.1 & 1.38 & 91.2 \\
\hline 518 & 06307640 & $\begin{array}{l}\text { Spring Creek near Ashland, } \\
\text { Montana }\end{array}$ & 45.5516 & -106.2857 & CSG & 15 & 1.60 & 23.5 & 18.4 & 73.5 & 1.08 & 25.0 \\
\hline 519 & 06307660 & $\begin{array}{l}\text { Walking Horse Creek near } \\
\text { Ashland, Montana }\end{array}$ & 45.6080 & -106.2882 & CSG & 16 & 3.26 & 36.8 & 9.3 & 55.9 & 1.10 & 26.5 \\
\hline 523 & 06307760 & $\begin{array}{l}\text { Stebbins Creek near Ashland, } \\
\text { Montana }\end{array}$ & 45.6199 & -106.4100 & CSG & 15 & 5.43 & 48.5 & 48.7 & 98.5 & 1.43 & 92.6 \\
\hline 527 & 06308100 & $\begin{array}{l}\text { Sixmile Creek tributary near } \\
\text { Epsie, Montana }\end{array}$ & 45.5242 & -105.7533 & $\mathrm{CSG}$ & 20 & 0.80 & 10.3 & 0.0 & 1.5 & 1.03 & 10.3 \\
\hline 529 & 06308300 & $\begin{array}{l}\text { Basin Creek near Volborg, } \\
\text { Montana }\end{array}$ & 45.8861 & -105.6647 & CSG & 19 & 11.1 & 66.2 & 12.4 & 66.2 & 1.16 & 41.2 \\
\hline 541 & 06309090 & $\begin{array}{l}\text { Ash Creek near Locate, } \\
\text { Montana }\end{array}$ & 46.3659 & -105.4974 & CSG & 15 & 6.27 & 54.4 & 20.6 & 79.4 & 1.25 & 63.2 \\
\hline 546 & 06325400 & $\begin{array}{l}\text { East Fork Little Powder River } \\
\text { tributary near Hammond, } \\
\text { Montana }\end{array}$ & 45.3003 & -105.0992 & CSG & 11 & 3.47 & 38.2 & 0.0 & 1.5 & 1.27 & 75.0 \\
\hline
\end{tabular}


Table 23. Information on discontinued streamgages in the Southeast Plains hydrologic region that might be candidates for reactivation to improve the streamgage network.Continued

[NAD 83, North American Datum of 1983; $n$, total number of years of peak-flow records; CONTDA, contributing drainage area, in square miles; FOREST, percentage of basin in forest; ET0306MOD, spring mean monthly evapotranspiration, in inches per month; CSG, crest-stage gage; CONT, continuous streamgage]

\begin{tabular}{|c|c|c|c|c|c|c|c|c|c|c|c|c|}
\hline $\begin{array}{l}\text { Map } \\
\text { number } \\
\text { (fig. 1) }\end{array}$ & $\begin{array}{c}\text { Station } \\
\text { identification } \\
\text { number }\end{array}$ & Station name & $\begin{array}{l}\text { Latitude, } \\
\text { in decimal } \\
\text { degrees } \\
\text { (NAD 83) }\end{array}$ & $\begin{array}{c}\text { Longitude, } \\
\text { in decimal } \\
\text { degrees } \\
\text { (NAD 83) }\end{array}$ & $\begin{array}{c}\text { Type of } \\
\text { streamgage }\end{array}$ & $n$ & $\begin{array}{c}\text { CONTDA, } \\
\text { in square } \\
\text { miles }\end{array}$ & $\begin{array}{c}\text { Non- } \\
\text { exceedance } \\
\text { percentile }{ }^{1} \\
\text { for CONTDA }\end{array}$ & FOREST & $\begin{array}{c}\text { Non- } \\
\text { exceedance } \\
\text { percentile }{ }^{1} \\
\text { for FOREST }\end{array}$ & ET0306MOD & $\begin{array}{c}\text { Non- } \\
\text { exceedance } \\
\text { percentile }{ }^{1} \text { for } \\
\text { ET0306MOD }\end{array}$ \\
\hline 547 & 06325500 & $\begin{array}{l}\text { Little Powder River near } \\
\text { Broadus, Montana }\end{array}$ & 45.3898 & -105.3054 & CONT & 25 & 1,962 & 100.0 & 4.0 & 41.2 & 1.20 & 47.1 \\
\hline 551 & 06326400 & $\begin{array}{l}\text { Meyers Creek near Locate, } \\
\text { Montana }\end{array}$ & 46.3880 & -105.2789 & CSG & 16 & 9.35 & 60.3 & 9.5 & 57.4 & 1.07 & 22.1 \\
\hline 553 & 06326510 & $\begin{array}{l}\text { Locate Creek tributary near } \\
\text { Locate, Montana }\end{array}$ & 46.4311 & -105.1819 & CSG & 19 & 0.90 & 17.6 & 6.7 & 50.0 & 1.12 & 30.9 \\
\hline 557 & 06326650 & $\begin{array}{l}\text { O'Fallon Creek tributary near } \\
\text { Ismay, Montana }\end{array}$ & 46.4193 & -104.7424 & CSG & 15 & 0.15 & 4.4 & 0.0 & 1.5 & 1.13 & 33.8 \\
\hline 558 & 06326700 & $\begin{array}{l}\text { Deep Creek near Baker, } \\
\text { Montana }\end{array}$ & 46.2990 & -104.3010 & CSG & 16 & 3.80 & 42.6 & 0.1 & 23.5 & 1.25 & 66.2 \\
\hline 567 & 06327700 & $\begin{array}{l}\text { Griffith Creek near Glendive, } \\
\text { Montana }\end{array}$ & 47.1034 & -104.5618 & CSG & 12 & 16.7 & 70.6 & 6.8 & 52.9 & 1.13 & 32.4 \\
\hline 580 & 06333850 & $\begin{array}{l}\text { North Creek near Alzada, } \\
\text { Montana }\end{array}$ & 45.0613 & -104.5293 & $\begin{array}{r}\mathrm{CONT} \\
\mathrm{CSG}\end{array}$ & 24 & 1.88 & 26.5 & 0.0 & 1.5 & 1.15 & 38.2 \\
\hline 583 & 06334200 & $\begin{array}{l}\text { Willow Creek near Alzada, } \\
\text { Montana }\end{array}$ & 45.1076 & -104.5943 & CSG & 16 & 122 & 80.9 & 0.0 & 20.6 & 1.24 & 58.8 \\
\hline 587 & 06334630 & $\begin{array}{l}\text { Boxelder Creek at Webster, } \\
\text { Montana }\end{array}$ & 45.9068 & -104.0576 & CONT & 15 & 1,097 & 95.6 & 2.9 & 38.2 & 1.26 & 70.6 \\
\hline 588 & 06334640 & $\begin{array}{l}\text { North Fork Coal Bank Creek } \\
\text { near Mill Iron, Montana }\end{array}$ & 45.9431 & -104.0928 & CSG & 15 & 15.5 & 69.1 & 0.0 & 22.1 & 1.30 & 80.9 \\
\hline 590 & 06336450 & $\begin{array}{l}\text { Spring Creek near Wibaux, } \\
\text { Montana }\end{array}$ & 46.8844 & -104.2004 & CONT & 18 & 3.91 & 44.1 & 0.0 & 1.5 & 1.27 & 76.5 \\
\hline
\end{tabular}

${ }^{1}$ The nonexceedance percentile for the basin or climatic variable value was calculated in relation to the values for all streamgages included in the regional regression analyses for the indicated hydrologic region. 

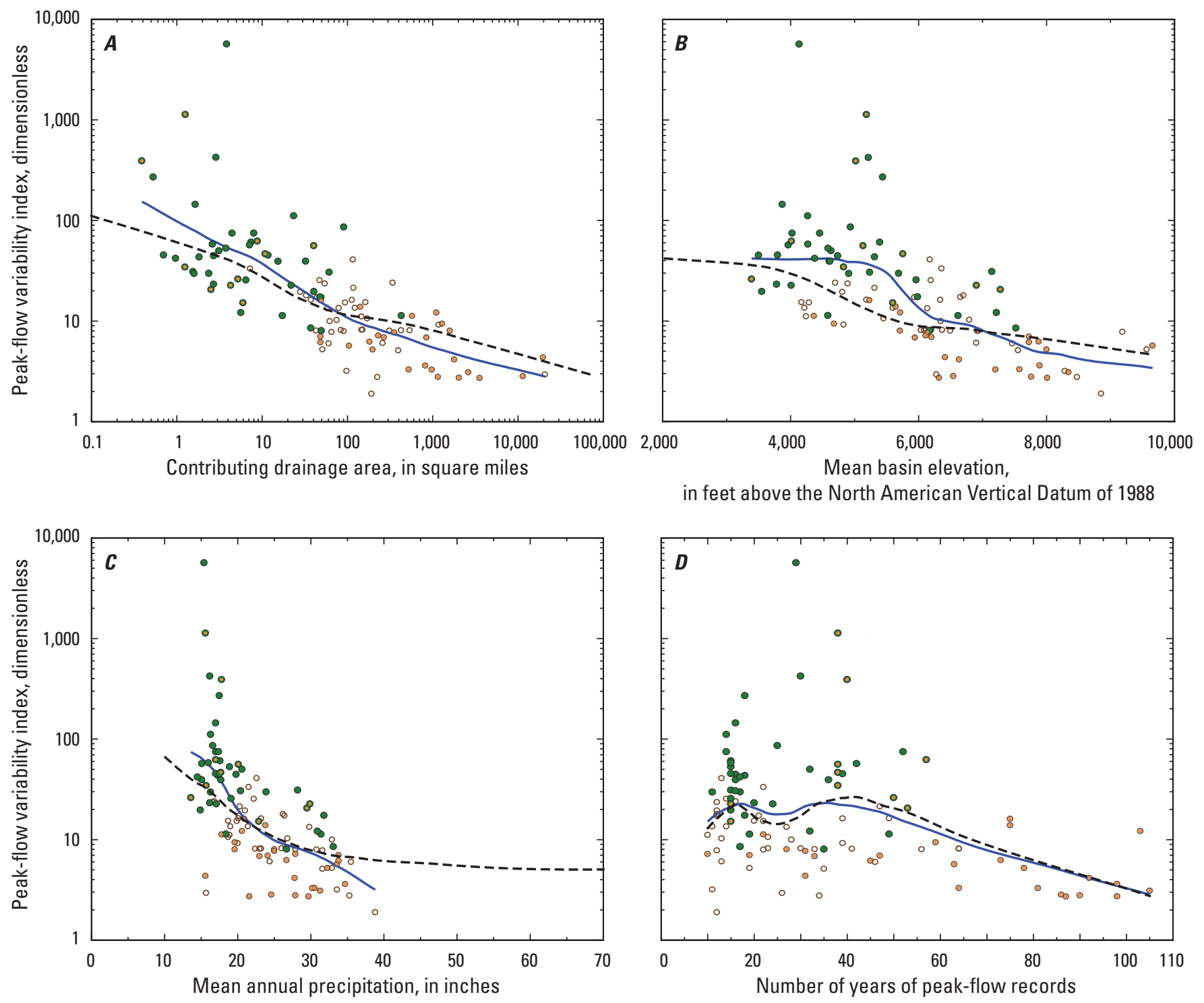

in feet above the North American Vertical Datum of 1988

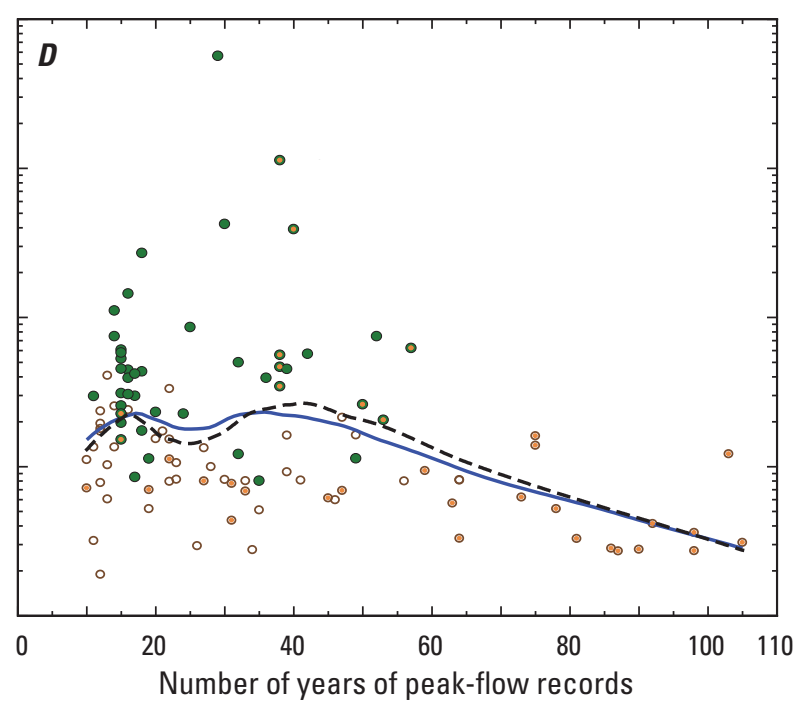

\section{EXPLANATION}

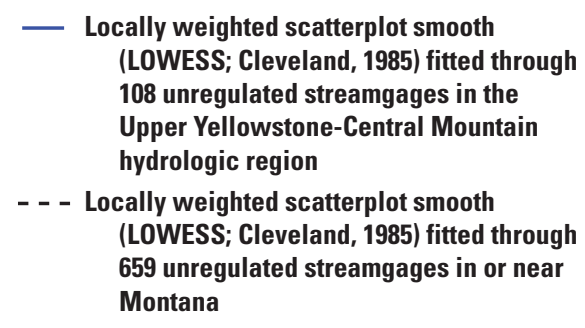

- Crest-stage streamgage

- Continuous streamgage

- Interior dot denotes active streamgage in water year 2017

Figure 24. Relations between peak-flow variability index and contributing drainage area, mean basin elevation, mean annual precipitation, and years of peak-flow records for 108 unregulated streamgages in the Upper Yellowstone-Central Mountain hydrologic region. $A$, Peak-flow variability and contributing drainage area relations. $B$, Peak-flow variability and mean basin elevation relations. $C$, Peak-flow variability and mean annual precipitation relations. $D$, Peak-flow variability and years of peak-flow records relations. 


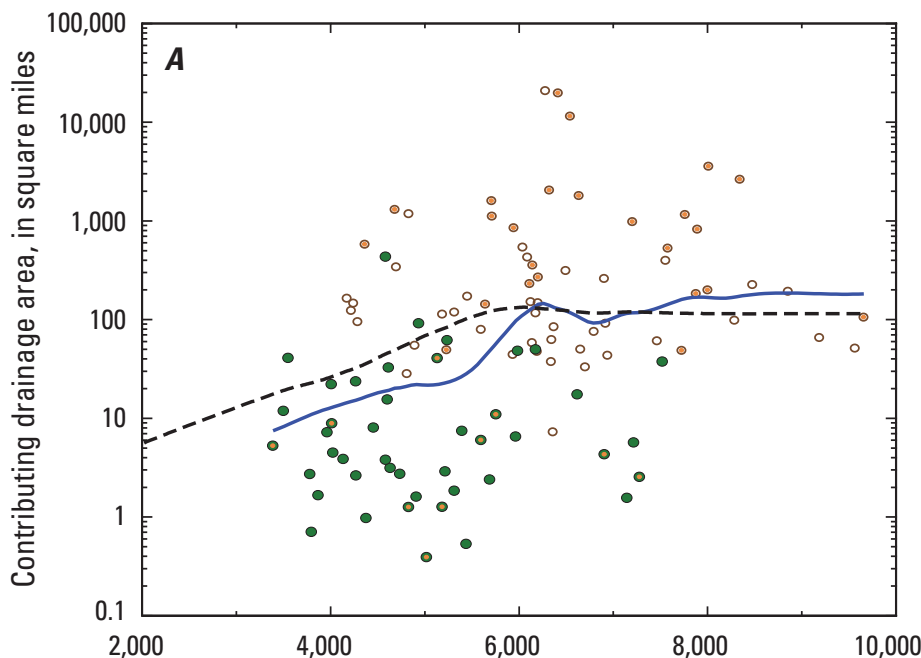

\section{EXPLANATION}

Locally weighted scatterplot smooth (LOWESS; Cleveland, 1985) fitted through 108 unregulated streamgages in the Upper Yellowstone-Central Mountain hydrologic region

- - - Locally weighted scatterplot smooth (LOWESS; Cleveland, 1985) fitted through 659 unregulated streamgages in or near Montana

- Crest-stage streamgage

- Continuous streamgage

Interior dot denotes active streamgage in water year 2017

Mean basin elevation, in feet above the North American Vertical Datum of 1988
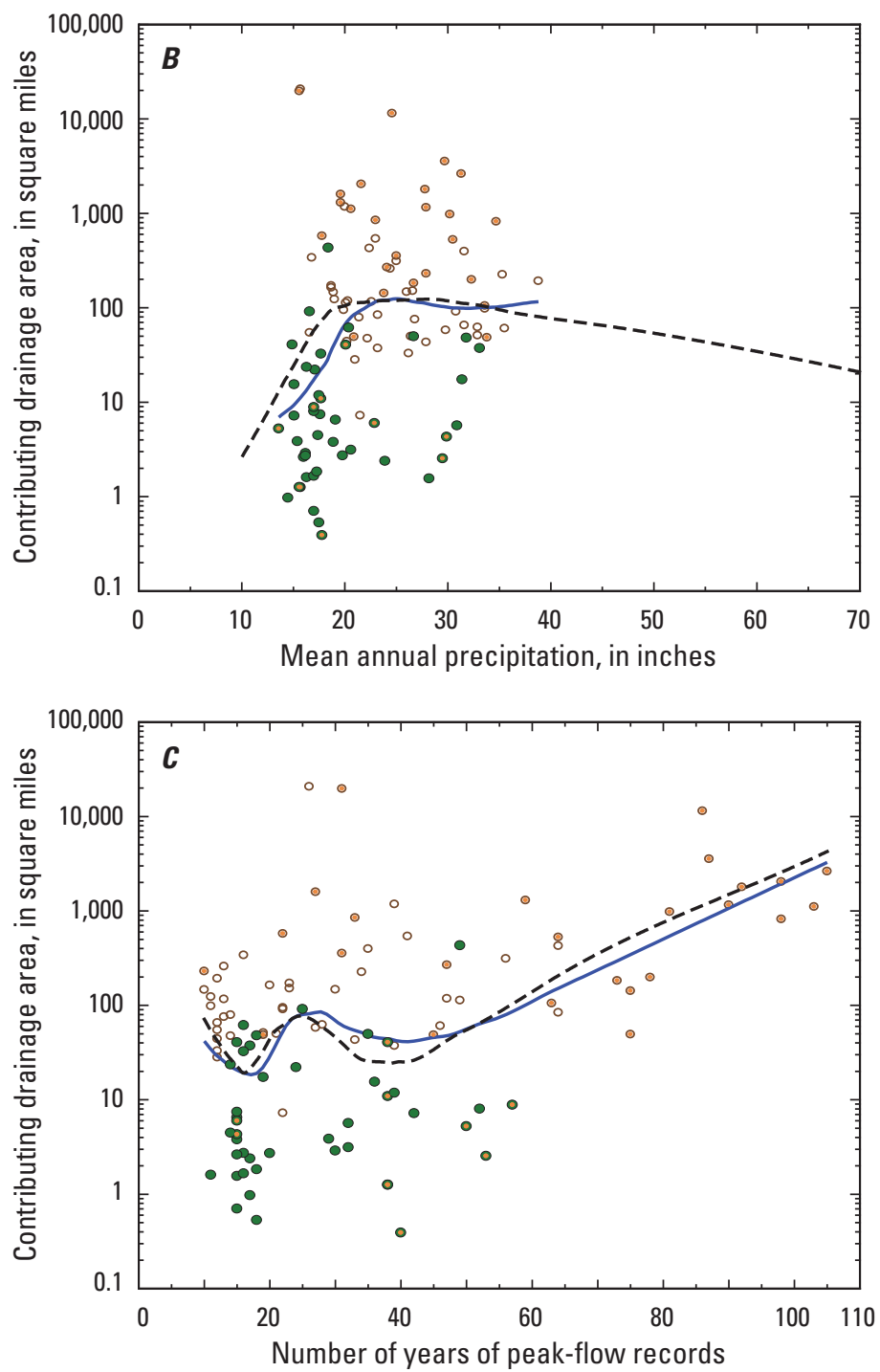

Figure 25. Relations between contributing drainage area and mean basin elevation, mean annual precipitation, and years of peak-flow records for 108 unregulated streamgages in the Upper Yellowstone-Central Mountain hydrologic region. $A$, Contributing drainage area and mean basin elevation relations. $B$, Contributing drainage area and mean annual precipitation relations. $C$, Contributing drainage area and years of peak-flow records relations. 

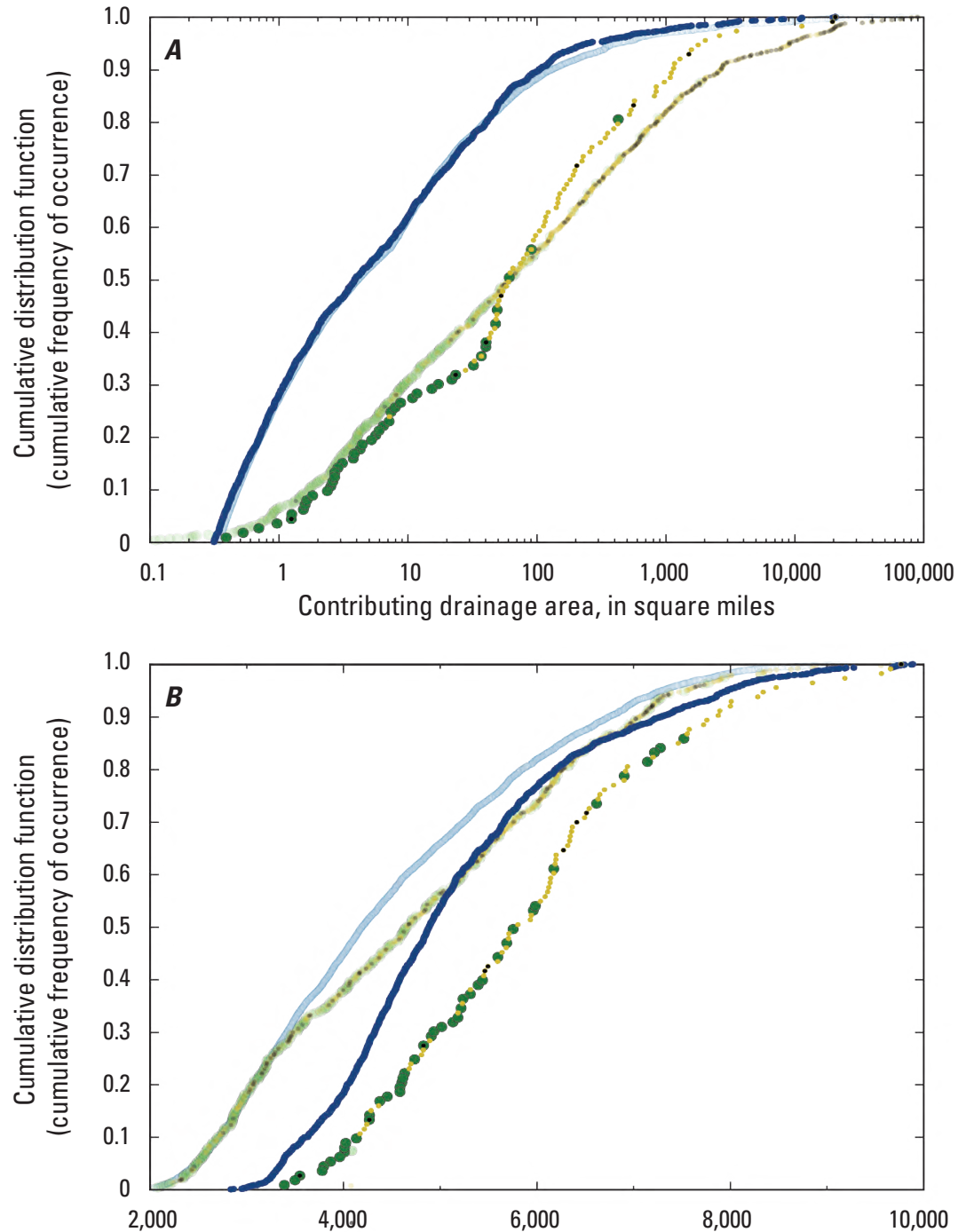

Mean basin elevation, in feet above the North American Vertical Datum of 1988

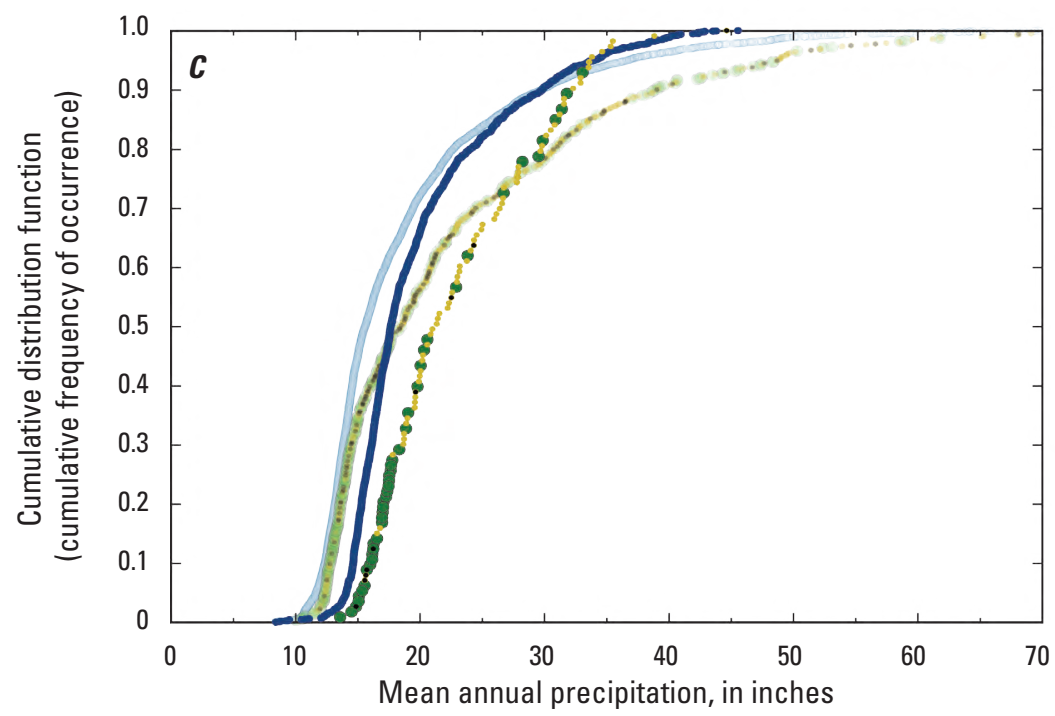

\section{EXPLANATION}

- Road and stream intersection in the Upper Yellowstone-Central Mountain hydrologic region

One of 12,639 road and stream intersections in Montana, as shown in figure 5 - Open symbols appear as solid symbols because of the high data density

Regulated and unregulated streamgages in the Upper Yellowstone-Central Mountain hydrologic region

- Crest-stage streamgage

- Unregulated continuous streamgage

- Regulated continuous streamgage

Regulated and unregulated streamgages in or near Montana, as shown in figure 5

Crest-stage streamgage in or near Montana Unregulated streamgages in or near Montana

Regulated streamgages in or near Montana

Figure 26. Cumulative distribution functions of selected drainage-basin characteristics for 2,166 road and stream intersections and for 113 streamgages (regulated and unregulated) in the Upper Yellowstone-Central Mountain hydrologic region. $A$, Contributing drainage area relations. $B$, Mean basin elevation relations. $C$, Mean annual precipitation relations. 
diverges from the CDF of road and stream intersections in the range of mean annual precipitation from about 18 to 22 inches, indicating small underrepresentation in that range.

The explanatory variables for the Upper YellowstoneCentral Mountain hydrologic region RREs are CONTDA and percent of basin above $6,000 \mathrm{ft}$ elevation $\left(E L_{6000}\right.$; table 6). The 1-percent AEP RRE for the Upper Yellowstone-Central Mountain hydrologic region has an SEP of 69.0 percent, which is somewhat higher than the area-weighted mean SEP for all hydrologic regions in Montana (63.3 percent; table 6). For the 1-percent AEP regression for the Upper YellowstoneCentral Mountain hydrologic region, 11.0 percent of the streamgages have significant leverage and 14.3 percent of the streamgages have significant influence (table 7); these percentages are higher than significant leverage and influence percentages (8.2 and 10.4 percent, respectively; table 7) for all of the streamgages in Montana used in the regional regression analyses.

Information on streamgages in the Upper YellowstoneCentral Mountain hydrologic region with significant leverage and influence is presented in table 24. One of the 10 significant leverage streamgages has the largest CONTDA value (nonexceedance percentile equal to 100 percent). Three of the 10 significant leverage streamgages have high $E L_{6000}$ values (nonexceedance percentiles greater than about 88 percent) in association with small CONTDA values (nonexceedance percentiles less than about 23 percent). Four of the 10 significant leverage streamgages have low $E L_{6000}$ values (nonexceedance percentiles equal to 1.1 percent). The 15 streamgages with significant influence vary with respect to the residuals for the 1-percent AEP RRE; 10 of the streamgages have negative residuals, and five have positive residuals. Three of the five streamgages with both significant leverage and significant influence have negative residuals and two have positive residuals.

In general, the streamgage network in the Upper Yellowstone-Central Mountain hydrologic region is considered to provide reasonable representation of the hydroclimatic settings of that hydrologic region. The RREs of the Upper Yellowstone-Central Mountain hydrologic region are considered to be reasonably reliable. Possible shortcomings of the streamgage network in the Upper Yellowstone-Central Mountain hydrologic region include small underrepresentation of basins with drainage areas from 10 to $32 \mathrm{mi}^{2}$, mean basin elevation less than about $5,100 \mathrm{ft}$, and (or) mean annual precipitation from 18 to 22 inches. Future improvements to the streamgage network in the Upper Yellowstone-Central Mountain hydrologic region might include establishing new CSGs or reactivating discontinued streamgages as CSGs on drainage basins with the specified characteristics. Information on discontinued streamgages in the Upper YellowstoneCentral Mountain hydrologic region that might be candidates for reactivation to improve the streamgage network is presented in table 25 .

\section{Peak-Flow Variability, Peak-Flow Informational Needs, and Consideration of Regional Regression Analyses in the Southwest Hydrologic Region}

The Southwest hydrologic region has an area of $14,891 \mathrm{mi}^{2}$ (table 1), which ranks sixth largest among the eight hydrologic regions. Level III ecoregions (table 2) represented in the Southwest hydrologic region include the Idaho Batholith (1.8 percent), Middle Rockies (95.5 percent), Northwestern Glaciated Plains ( 0.8 percent), and Northwestern Great Plains (1.9 percent). The 2,267 road and stream intersections in the Southwest hydrologic region (tables 4 and 5) represent a density of 0.152 road and stream intersection per $\mathrm{mi}^{2}$, which ranks first among the hydrologic regions. The 84 streamgages (both regulated and unregulated; tables 4 and 5) represent an areal density of 0.00564 streamgage per $\mathrm{mi}^{2}$ (ranking third among hydrologic regions) and a density of 0.03705 streamgage per road and stream intersection (ranking eighth among hydrologic regions).

Relations between $P F V I$ and contributing drainage area, mean basin elevation, mean annual precipitation, and years of peak-flow records for 67 unregulated streamgages in the Southwest hydrologic region (table 3 ) are presented in figure 27. For the 67 unregulated streamgages, $P F V I$ generally monotonically decreases with increasing drainage area (fig. 27A). Intuitively, highly variable small-scale hydroclimatic processes are integrated with increasing drainage area such that variability in many hydrologic characteristics is reduced. For drainage areas smaller than about $20 \mathrm{mi}^{2}$, variability in $P F V I$ is large and the LOWESS line for the streamgages in the Southwest hydrologic region is above the LOWESS line for all unregulated streamgages in Montana. For drainage areas larger than about $20 \mathrm{mi}^{2}$, variability in PFVI is small and the LOWESS line for the streamgages in the Southwest hydrologic region is near or below the LOWESS line for all unregulated streamgages in Montana. PFVI also decreases with increasing elevation (fig. $27 B$ ), precipitation (fig. 27C), and years of record (fig. 27D). For the relations between PFVI and elevation (fig. 27B) and precipitation (fig. 27C), the LOWESS lines for the Southwest hydrologic region are above the LOWESS lines for all unregulated streamgages in Montana at elevations less than about 6,500 ft and precipitation less than about 18 inches.

Relations between contributing drainage area and mean basin elevation, mean annual precipitation, and years of peakflow records for the unregulated streamgages are presented in figure 28. Streamgages with greater than about 60 years of record are predominantly located on streams with contributing drainage areas greater than about $100 \mathrm{mi}^{2}$ (fig. 28C), which likely contributes to the $P F V I$ and years of record relations (fig. 27D).

The median PFVI value for streamgages in the Southwest hydrologic region $(9.30$, table 3$)$ is less than the median for all unregulated streamgages in Montana (18.26, table 3) 
Table 24. Information on streamgages in the Upper Yellowstone-Central Mountain hydrologic region with significant leverage and influence in the Montana regional regression analyses (Sando, R., and others, 2018).

[ID, identification; NAD 83, North American Datum of 1983; n, total number of years of peak-flow records; CONTDA, contributing drainage area, in square miles; $E L_{6000}$, percentage of basin above 6,000 feet elevation; AEP, annual exceedance probability; CSG, crest-stage gage; CONT, continuous streamgage]

\begin{tabular}{|c|c|c|c|c|c|c|c|c|c|c|c|c|c|c|}
\hline \multirow{2}{*}{$\begin{array}{l}\text { Map } \\
\text { number } \\
\text { (fig. 1) }\end{array}$} & \multirow{2}{*}{$\begin{array}{l}\text { Streamgage } \\
\text { ID number }\end{array}$} & \multirow{2}{*}{$\begin{array}{c}\text { Streamgage } \\
\text { name }\end{array}$} & \multirow{2}{*}{$\begin{array}{l}\text { Latitude, } \\
\text { in decimal } \\
\text { degrees } \\
\text { (NAD 83) }\end{array}$} & \multirow{2}{*}{$\begin{array}{l}\text { Longitude, } \\
\text { in decimal } \\
\text { degrees } \\
\text { (NAD 83) }\end{array}$} & \multirow{2}{*}{$\begin{array}{c}\text { Type of } \\
\text { streamgage }\end{array}$} & \multirow{2}{*}{$\begin{array}{c}\text { Status of } \\
\text { streamgage } \\
\text { in water year } \\
2017\end{array}$} & \multirow[t]{2}{*}{$n$} & \multirow[t]{2}{*}{ CONTDA } & \multirow{2}{*}{$\begin{array}{l}\text { Non- } \\
\text { exceedance } \\
\text { percentile }{ }^{1} \\
\text { for CONTDA }\end{array}$} & \multirow{2}{*}{$E L_{6000}$} & \multirow{2}{*}{$\begin{array}{l}\text { Non- } \\
\text { exceedance } \\
\text { percentile }{ }^{1} \\
\text { for } E L_{6000}\end{array}$} & \multicolumn{3}{|c|}{$\begin{array}{c}\text { Regression residuals for } \\
\text { the specified AEP } \\
\text { regression analyses }\end{array}$} \\
\hline & & & & & & & & & & & & $\begin{array}{c}\text { 10-percent } \\
\text { AEP }\end{array}$ & $\begin{array}{c}\text { 4-percent } \\
\text { AEP }\end{array}$ & $\begin{array}{c}\text { 1-percent } \\
\text { AEP }\end{array}$ \\
\hline \multicolumn{15}{|c|}{ Streamgages with significant leverage } \\
\hline 79 & ${ }^{2} 06043300$ & $\begin{array}{l}\text { Logger Creek } \\
\text { near Gallatin } \\
\text { Gateway, } \\
\text { Montana }\end{array}$ & 45.4540 & -111.2449 & CSG & Active & 58 & 2.53 & 12.1 & 90.39 & 88.5 & -0.319 & -0.319 & -0.298 \\
\hline 88 & 06052500 & $\begin{array}{l}\text { Gallatin River } \\
\text { at Logan, } \\
\text { Montana }\end{array}$ & 45.8854 & -111.4383 & CONT & Active & 97 & 1,789 & 98.9 & 60.30 & 78.2 & -0.043 & -0.102 & -0.162 \\
\hline 120 & 06076700 & $\begin{array}{l}\text { Sheep Creek } \\
\text { near Neihart, } \\
\text { Montana }\end{array}$ & 46.7996 & -110.7037 & CSG & Discontinued & 32 & 5.65 & 23.1 & 100.00 & 100.0 & -0.038 & -0.095 & -0.164 \\
\hline 121 & ${ }^{2} 06076800$ & $\begin{array}{l}\text { Nugget Creek } \\
\text { near Neihart, } \\
\text { Montana }\end{array}$ & 46.7749 & -110.7015 & CSG & Discontinued & 15 & 1.55 & 6.6 & 100.00 & 100.0 & -0.328 & -0.336 & -0.329 \\
\hline 193 & 06111000 & $\begin{array}{l}\text { Ross Fork } \\
\text { Creek near } \\
\text { Hobson, } \\
\text { Montana }\end{array}$ & 46.9927 & -109.7951 & CONT & Discontinued & 16 & 340 & 85.7 & 3.11 & 35.6 & -0.234 & -0.270 & -0.318 \\
\hline 208 & ${ }^{2} 06117800$ & $\begin{array}{l}\text { Big Coulee } \\
\text { near } \\
\text { Martinsdale, } \\
\text { Montana }\end{array}$ & 46.5499 & -110.3151 & CSG & Discontinued & 30 & 2.88 & 16.5 & 0.00 & 1.1 & 0.343 & 0.398 & 0.376 \\
\hline 222 & ${ }^{2} 06123200$ & $\begin{array}{l}\text { Sadie Creek } \\
\text { tributary near } \\
\text { Harlowton, } \\
\text { Montana }\end{array}$ & 46.1912 & -109.9005 & CSG & Active & 45 & 0.39 & 1.1 & 0.00 & 1.1 & 0.589 & 0.735 & 0.901 \\
\hline 448 & 06208500 & $\begin{array}{l}\text { Clarks Fork } \\
\text { Yellowstone } \\
\text { River at } \\
\text { Edgar, } \\
\text { Montana }\end{array}$ & 45.4657 & -108.8441 & CONT & Active & 78 & 2,034 & 100.0 & 45.42 & 62.1 & 0.047 & -0.032 & -0.113 \\
\hline
\end{tabular}


Table 24. Information on streamgages in the Upper Yellowstone-Central Mountain hydrologic region with significant leverage and influence in the Montana regional regression analyses (Sando, R., and others, 2018).-Continued

[ID, identification; NAD 83, North American Datum of 1983; n, total number of years of peak-flow records; $C O N T D A$, contributing drainage area, in square miles; $E L_{6000}$, percentage of basin above 6,000 feet elevation; AEP, annual exceedance probability; CSG, crest-stage gage; CONT, continuous streamgage]

\begin{tabular}{|c|c|c|c|c|c|c|c|c|c|c|c|c|c|c|}
\hline \multirow{2}{*}{$\begin{array}{c}\text { Map } \\
\text { number } \\
\text { (fig. 1) }\end{array}$} & \multirow{2}{*}{$\begin{array}{l}\text { Streamgage } \\
\text { ID number }\end{array}$} & \multirow{2}{*}{$\begin{array}{c}\text { Streamgage } \\
\text { name }\end{array}$} & \multirow{2}{*}{$\begin{array}{l}\text { Latitude, } \\
\text { in decimal } \\
\text { degrees } \\
\text { (NAD 83) }\end{array}$} & \multirow{2}{*}{$\begin{array}{l}\text { Longitude, } \\
\text { in decimal } \\
\text { degrees } \\
\text { (NAD 83) }\end{array}$} & \multirow{2}{*}{$\begin{array}{c}\text { Type of } \\
\text { streamgage }\end{array}$} & \multirow{2}{*}{$\begin{array}{c}\text { Status of } \\
\text { streamgage } \\
\text { in water } \\
\text { year } 2017\end{array}$} & \multirow[t]{2}{*}{$n$} & \multirow{2}{*}{ CONTDA } & \multirow{2}{*}{$\begin{array}{c}\text { Non- } \\
\text { exceedance } \\
\text { percentile } \\
\text { for CONTDA }\end{array}$} & \multirow{2}{*}{$E L_{6000}$} & \multirow{2}{*}{$\begin{array}{c}\text { Non- } \\
\text { exceedance } \\
\text { percentile }{ }^{1} \\
\text { for } E L_{6000}\end{array}$} & \multicolumn{3}{|c|}{$\begin{array}{l}\text { Regression residuals for } \\
\text { the specified AEP } \\
\text { regression analyses }\end{array}$} \\
\hline & & & & & & & & & & & & $\begin{array}{c}\text { 10-percent } \\
\text { AEP }\end{array}$ & $\begin{array}{l}\text { 4-percent } \\
\text { AEP }\end{array}$ & $\begin{array}{c}\text { 1-percent } \\
\text { AEP }\end{array}$ \\
\hline \multicolumn{15}{|c|}{ Streamgages with significant leverage-Continued } \\
\hline 461 & 06216200 & $\begin{array}{l}\text { West Wets } \\
\text { Creek near } \\
\text { Billings, } \\
\text { Montana }\end{array}$ & 45.6270 & -108.4045 & CSG & Active & 62 & 8.82 & 29.7 & 0.00 & 1.1 & 0.220 & 0.204 & 0.169 \\
\hline 482 & ${ }^{2} 06293300$ & $\begin{array}{l}\text { Long Otter } \\
\text { Creek near } \\
\text { Lodge } \\
\text { Grass, } \\
\text { Montana }\end{array}$ & 45.4540 & -107.3959 & CSG & Discontinued & 40 & 11.8 & 31.9 & 0.00 & 1.1 & -0.187 & -0.265 & -0.357 \\
\hline \multicolumn{15}{|c|}{ Streamgages with significant influence } \\
\hline 79 & ${ }^{2} 06043300$ & $\begin{array}{l}\text { Logger Creek } \\
\text { near Gallatin } \\
\text { Gateway, } \\
\text { Montana }\end{array}$ & 45.4540 & -111.2449 & CSG & Active & 58 & 2.53 & 12.1 & 90.39 & 88.5 & -0.319 & -0.319 & -0.298 \\
\hline 117 & 06075600 & $\begin{array}{c}\text { Fivemile Creek } \\
\text { near White } \\
\text { Sulphur } \\
\text { Springs, } \\
\text { Montana }\end{array}$ & 46.6128 & -110.7567 & CSG & Discontinued & 15 & 6.48 & 24.2 & 40.08 & 59.8 & -0.600 & -0.612 & -0.607 \\
\hline 118 & 06076000 & $\begin{array}{c}\text { Newlan Creek } \\
\text { near White } \\
\text { Sulphur } \\
\text { Springs, } \\
\text { Montana }\end{array}$ & 46.7316 & -110.8387 & CONT & Discontinued & 22 & 7.23 & 26.4 & 80.67 & 83.9 & -0.560 & -0.530 & -0.482 \\
\hline 121 & ${ }^{2} 06076800$ & $\begin{array}{l}\text { Nugget Creek } \\
\text { near Neihart, } \\
\text { Montana }\end{array}$ & 46.7749 & -110.7015 & $\mathrm{CSG}$ & Discontinued & 15 & 1.55 & 6.6 & 100.00 & 100.0 & -0.328 & -0.336 & -0.329 \\
\hline 144 & 06090550 & $\begin{array}{l}\text { Little Otter } \\
\text { Creek near } \\
\text { Raynesford, } \\
\text { Montana }\end{array}$ & 47.2518 & -110.7316 & $\mathrm{CSG}$ & Active & 43 & 40.4 & 42.9 & 4.37 & 37.9 & -0.774 & -0.677 & -0.514 \\
\hline
\end{tabular}


Table 24. Information on streamgages in the Upper Yellowstone-Central Mountain hydrologic region with significant leverage and influence in the Montana regional regression analyses (Sando, R., and others, 2018).-Continued

[ID, identification; NAD 83, North American Datum of 1983; n, total number of years of peak-flow records; $C O N T D A$, contributing drainage area, in square miles; $E L_{6000}$, percentage of basin above 6,000 feet elevation; AEP, annual exceedance probability; CSG, crest-stage gage; CONT, continuous streamgage]

\begin{tabular}{|c|c|c|c|c|c|c|c|c|c|c|c|c|c|c|}
\hline \multirow{2}{*}{$\begin{array}{l}\text { Map } \\
\text { number } \\
\text { (fig. 1) }\end{array}$} & \multirow{2}{*}{$\begin{array}{l}\text { Streamgage } \\
\text { ID number }\end{array}$} & \multirow{2}{*}{$\begin{array}{c}\text { Streamgage } \\
\text { name }\end{array}$} & \multirow{2}{*}{$\begin{array}{l}\text { Latitude, } \\
\text { in decimal } \\
\text { degrees } \\
\text { (NAD 83) }\end{array}$} & \multirow{2}{*}{$\begin{array}{l}\text { Longitude, } \\
\text { in decimal } \\
\text { degrees } \\
\text { (NAD 83) }\end{array}$} & \multirow{2}{*}{$\begin{array}{c}\text { Type of } \\
\text { streamgage }\end{array}$} & \multirow{2}{*}{$\begin{array}{c}\text { Status of } \\
\text { streamgage } \\
\text { in water } \\
\text { year } 2017\end{array}$} & \multirow[t]{2}{*}{$n$} & \multirow[t]{2}{*}{ CONTDA } & \multirow{2}{*}{$\begin{array}{c}\text { Non- } \\
\text { exceedance } \\
\text { percentile } 1 \\
\text { for CONTDA }\end{array}$} & \multirow{2}{*}{$E L_{6000}$} & \multirow{2}{*}{$\begin{array}{c}\text { Non- } \\
\text { exceedance } \\
\text { percentile }{ }^{1} \\
\text { for } E L_{6000}\end{array}$} & \multicolumn{3}{|c|}{$\begin{array}{c}\text { Regression residuals for } \\
\text { the specified AEP } \\
\text { regression analyses }\end{array}$} \\
\hline & & & & & & & & & & & & $\begin{array}{l}\text { 10-percent } \\
\text { AEP }\end{array}$ & $\begin{array}{c}\text { 4-percent } \\
\text { AEP }\end{array}$ & $\begin{array}{c}\text { 1-percent } \\
\text { AEP }\end{array}$ \\
\hline \multicolumn{15}{|c|}{ Streamgages with significant influence-Continued } \\
\hline 197 & 06114500 & $\begin{array}{l}\text { Wolf Creek } \\
\text { near } \\
\text { Stanford, } \\
\text { Montana }\end{array}$ & 47.1190 & -110.2872 & CONT & Discontinued & 13 & 116 & 69.2 & 53.86 & 70.1 & -1.066 & -0.851 & -0.519 \\
\hline 208 & ${ }^{2} 06117800$ & $\begin{array}{l}\text { Big Coulee } \\
\text { near } \\
\text { Martinsdale, } \\
\text { Montana }\end{array}$ & 46.5499 & -110.3151 & CSG & Discontinued & 30 & 2.88 & 16.5 & 0.00 & 1.1 & 0.343 & 0.398 & 0.376 \\
\hline 212 & 06120500 & $\begin{array}{l}\text { Musselshell } \\
\text { River at } \\
\text { Harlowton, } \\
\text { Montana }\end{array}$ & 46.4288 & -109.8412 & CONT & Active & 108 & 1,108 & 95.6 & 31.86 & 56.3 & -0.352 & -0.350 & -0.336 \\
\hline 214 & 06120700 & $\begin{array}{l}\text { Antelope } \\
\text { Creek } \\
\text { tributary near } \\
\text { mouth, near } \\
\text { Harlowton, } \\
\text { Montana }\end{array}$ & 46.6192 & -109.9519 & CSG & Discontinued & 18 & 1.83 & 9.9 & 0.00 & 1.1 & 0.554 & 0.506 & 0.459 \\
\hline 215 & 06120800 & $\begin{array}{l}\text { Alkali Creek } \\
\text { near } \\
\text { Harlowton, } \\
\text { Montana }\end{array}$ & 46.4643 & -109.8229 & CSG & Discontinued & 36 & 15.4 & 33.0 & 0.00 & 1.1 & 0.477 & 0.566 & 0.719 \\
\hline 216 & 06120900 & $\begin{array}{l}\text { Antelope } \\
\text { Creek at } \\
\text { Harlowton, } \\
\text { Montana }\end{array}$ & 46.4385 & -109.8225 & CSG & Discontinued & 25 & 90.9 & 62.6 & 6.91 & 39.1 & 0.406 & 0.676 & 0.963 \\
\hline 222 & ${ }^{2} 06123200$ & $\begin{array}{l}\text { Sadie Creek } \\
\text { tributary near } \\
\text { Harlowton, } \\
\text { Montana }\end{array}$ & 46.1912 & -109.9005 & CSG & Active & 45 & 0.39 & 1.1 & 0.00 & 1.1 & 0.589 & 0.735 & 0.901 \\
\hline
\end{tabular}


Table 24. Information on streamgages in the Upper Yellowstone-Central Mountain hydrologic region with significant leverage and influence in the Montana regional regression analyses (Sando, R., and others, 2018).-Continued

[ID, identification; NAD 83, North American Datum of 1983; n, total number of years of peak-flow records; $C O N T D A$, contributing drainage area, in square miles; $E L_{6000}$, percentage of basin above 6,000 feet elevation; AEP, annual exceedance probability; CSG, crest-stage gage; CONT, continuous streamgage]

\begin{tabular}{|c|c|c|c|c|c|c|c|c|c|c|c|c|c|c|}
\hline \multirow{2}{*}{$\begin{array}{c}\text { Map } \\
\text { number } \\
\text { (fig. 1) }\end{array}$} & \multirow{2}{*}{$\begin{array}{l}\text { Streamgage } \\
\text { ID number }\end{array}$} & \multirow{2}{*}{$\begin{array}{c}\text { Streamgage } \\
\text { name }\end{array}$} & \multirow{2}{*}{$\begin{array}{l}\text { Latitude, } \\
\text { in decimal } \\
\text { degrees } \\
\text { (NAD 83) }\end{array}$} & \multirow{2}{*}{$\begin{array}{l}\text { Longitude, } \\
\text { in decimal } \\
\text { degrees } \\
\text { (NAD 83) }\end{array}$} & \multirow{2}{*}{$\begin{array}{c}\text { Type of } \\
\text { streamgage }\end{array}$} & \multirow{2}{*}{$\begin{array}{c}\text { Status of } \\
\text { streamgage } \\
\text { in water } \\
\text { year } 2017\end{array}$} & \multirow[t]{2}{*}{$n$} & \multirow[t]{2}{*}{ CONTDA } & \multirow{2}{*}{$\begin{array}{c}\text { Non- } \\
\text { exceedance } \\
\text { percentile }{ }^{1} \\
\text { for CONTDA }\end{array}$} & \multirow{2}{*}{$E L_{6000}$} & \multirow{2}{*}{$\begin{array}{l}\text { Non- } \\
\text { exceedance } \\
\text { percentile }{ }^{1} \\
\text { for } E L_{6000}\end{array}$} & \multicolumn{3}{|c|}{$\begin{array}{l}\text { Regression residuals for } \\
\text { the specified AEP } \\
\text { regression analyses }\end{array}$} \\
\hline & & & & & & & & & & & & $\begin{array}{c}\text { 10-percent } \\
\text { AEP }\end{array}$ & $\begin{array}{c}\text { 4-percent } \\
\text { AEP }\end{array}$ & $\begin{array}{c}\text { 1-percent } \\
\text { AEP }\end{array}$ \\
\hline \multicolumn{15}{|c|}{ Streamgages with significant influence-Continued } \\
\hline 245 & 06129100 & $\begin{array}{l}\text { North Fork } \\
\text { McDonald } \\
\text { Creek } \\
\text { tributary } \\
\text { near Heath, } \\
\text { Montana }\end{array}$ & 47.0684 & -109.2137 & CSG & Discontinued & 16 & 2.72 & 15.4 & 0.00 & 1.1 & -0.322 & -0.441 & -0.554 \\
\hline 457 & 06214150 & $\begin{array}{l}\text { Mills Creek } \\
\text { at Rapelje, } \\
\text { Montana }\end{array}$ & 45.9674 & -109.2554 & CSG & Discontinued & 29 & 3.85 & 19.8 & 0.00 & 1.1 & -0.585 & -0.468 & -0.342 \\
\hline 482 & ${ }^{2} 06293300$ & $\begin{array}{l}\text { Long Otter } \\
\text { Creek near } \\
\text { Lodge } \\
\text { Grass, } \\
\text { Montana }\end{array}$ & 45.4540 & -107.3959 & CSG & Discontinued & 40 & 11.8 & 31.9 & 0.00 & 1.1 & -0.187 & -0.265 & -0.357 \\
\hline
\end{tabular}

${ }^{1}$ The nonexceedance percentile for the basin or climatic variable value was calculated in relation to the values for all streamgages included in the regional regression analyses for the indicated hydrologic region.

${ }^{2}$ Streamgages having both significant leverage and significant influence. 
Table 25. Information on discontinued streamgages in the Upper Yellowstone-Central Mountain hydrologic region that might be candidates for reactivation to improve the streamgage network.

[NAD 83, North American Datum of $1983 ; n$, total number of years of peak-flow records; $C O N T D A$, contributing drainage area, in square miles; $E L_{6000}$, percentage of basin above 6,000 feet elevation; CONT, continuous streamgage; CSG, crest-stage gage]

\begin{tabular}{|c|c|c|c|c|c|c|c|c|c|c|}
\hline $\begin{array}{c}\text { Map } \\
\text { number } \\
\text { (fig. 1) }\end{array}$ & $\begin{array}{c}\text { Station } \\
\text { identification } \\
\text { number }\end{array}$ & Station name & $\begin{array}{c}\text { Latitude, } \\
\text { in decimal } \\
\text { degrees } \\
\text { (NAD 83) }\end{array}$ & $\begin{array}{c}\text { Longitude, } \\
\text { in decimal } \\
\text { degrees } \\
\text { (NAD 83) }\end{array}$ & $\begin{array}{c}\text { Type of } \\
\text { streamgage }\end{array}$ & $n$ & CONTDA & $\begin{array}{l}\text { Nonexceedance } \\
\text { percentile }{ }^{1} \text { for } \\
\text { CONTDA }\end{array}$ & $E L_{6000}$ & $\begin{array}{c}\text { Nonexceedance } \\
\text { percentile }{ }^{1} \text { for } \\
E L_{6000}\end{array}$ \\
\hline 77 & 06043000 & Taylor Creek near Grayling, Montana & 45.0709 & -111.2052 & CONT & 11 & 98.0 & 65.9 & 100.0 & 95.6 \\
\hline 78 & 06043200 & Squaw Creek near Gallatin Gateway, Montana & 45.4414 & -111.2067 & CSG & 17 & 37.3 & 40.7 & 97.2 & 91.2 \\
\hline 82 & 06046700 & Pitcher Creek near Bozeman, Montana & 45.6549 & -110.9426 & CSG & 17 & 2.38 & 11.0 & 16.3 & 45.1 \\
\hline 83 & 06047000 & Bear Canyon near Bozeman, Montana & 45.6241 & -110.9349 & $\begin{array}{r}\mathrm{CONT}, \\
\mathrm{CSG}\end{array}$ & 19 & 17.3 & 34.1 & 85.9 & 82.4 \\
\hline 84 & 06048000 & East Gallatin River at Bozeman, Montana & 45.7005 & -111.0293 & CONT & 23 & 151 & 75.8 & 51.5 & 64.8 \\
\hline 116 & 06074500 & $\begin{array}{l}\text { Smith River near White Sulphur Springs, } \\
\text { Montana }\end{array}$ & 46.6717 & -110.7234 & CONT & 12 & 32.9 & 39.6 & 80.4 & 79.1 \\
\hline 117 & 06075600 & $\begin{array}{l}\text { Fivemile Creek near White Sulphur Springs, } \\
\text { Montana }\end{array}$ & 46.6128 & -110.7567 & CSG & 15 & 6.48 & 24.2 & 40.1 & 57.1 \\
\hline 118 & 06076000 & $\begin{array}{l}\text { Newlan Creek near White Sulphur Springs, } \\
\text { Montana }\end{array}$ & 46.7316 & -110.8387 & CONT & 22 & 7.23 & 26.4 & 80.7 & 80.2 \\
\hline 121 & 06076800 & Nugget Creek near Neihart, Montana & 46.7749 & -110.7015 & CSG & 15 & 1.55 & 6.6 & 100.0 & 95.6 \\
\hline 124 & 06077300 & Trout Creek near Eden, Montana & 47.1109 & -111.3668 & CSG & 11 & 1.60 & 7.7 & 0.0 & 1.1 \\
\hline 126 & 06077700 & Smith River tributary near Eden, Montana & 47.3064 & -111.4245 & CSG & 16 & 1.65 & 8.8 & 0.0 & 1.1 \\
\hline 127 & 06077800 & Goodman Coulee near Eden, Montana & 47.3237 & -111.4272 & CSG & 24 & 22.0 & 35.2 & 0.0 & 1.1 \\
\hline 190 & 06109800 & South Fork Judith River near Utica, Montana & 46.7534 & -110.3232 & CONT & 21 & 49.9 & 51.6 & 92.2 & 85.7 \\
\hline 191 & 06109900 & Judith River tributary near Utica, Montana & 46.8824 & -110.2659 & CSG & 15 & 7.42 & 27.5 & 7.5 & 38.5 \\
\hline 193 & 06111000 & Ross Fork Creek near Hobson, Montana & 46.9927 & -109.7951 & CONT & 16 & 340 & 85.7 & 3.1 & 34.1 \\
\hline 195 & 06112100 & Cottonwood Creek near Moore, Montana & 46.9790 & -109.4939 & $\begin{array}{r}\text { CONT, } \\
\text { CSG }\end{array}$ & 18 & 47.9 & 47.3 & 43.6 & 58.2 \\
\hline 197 & 06114500 & Wolf Creek near Stanford, Montana & 47.1190 & -110.2872 & CONT & 13 & 116 & 69.2 & 53.9 & 67.0 \\
\hline 213 & 06120600 & $\begin{array}{l}\text { Antelope Creek tributary near Harlowton, } \\
\text { Montana }\end{array}$ & 46.6411 & -109.9776 & CSG & 18 & 0.53 & 2.2 & 0.0 & 1.1 \\
\hline 214 & 06120700 & $\begin{array}{l}\text { Antelope Creek tributary near mouth, near } \\
\text { Harlowton, Montana }\end{array}$ & 46.6192 & -109.9519 & CSG & 18 & 1.83 & 9.9 & 0.0 & 1.1 \\
\hline 216 & 06120900 & Antelope Creek at Harlowton, Montana & 46.4385 & -109.8225 & CSG & 25 & 90.9 & 62.6 & 6.9 & 37.4 \\
\hline 217 & 06121000 & American Fork near Harlowton, Montana & 46.3740 & -109.7921 & CONT & 14 & 79.1 & 60.4 & 26.8 & 50.5 \\
\hline 218 & 06121500 & Lebo Creek near Harlowton, Montana & 46.3804 & -109.7993 & CONT & 12 & 54.6 & 53.8 & 0.0 & 1.1 \\
\hline
\end{tabular}


Table 25. Information on discontinued streamgages in the Upper Yellowstone-Central Mountain hydrologic region that might be candidates for reactivation to improve the streamgage network.-Continued

[NAD 83, North American Datum of 1983; $n$, total number of years of peak-flow records; CONTDA, contributing drainage area, in square miles; $E L_{6000}$, percentage of basin above 6,000 feet elevation; CONT, continuous streamgage; CSG, crest-stage gage]

\begin{tabular}{|c|c|c|c|c|c|c|c|c|c|c|}
\hline $\begin{array}{c}\text { Map } \\
\text { number } \\
\text { (fig. 1) }\end{array}$ & $\begin{array}{c}\text { Station } \\
\text { identification } \\
\text { number }\end{array}$ & Station name & $\begin{array}{l}\text { Latitude, } \\
\text { in decimal } \\
\text { degrees } \\
\text { (NAD 83) }\end{array}$ & $\begin{array}{c}\text { Longitude, } \\
\text { in decimal } \\
\text { degrees } \\
\text { (NAD 83) }\end{array}$ & $\begin{array}{l}\text { Type of } \\
\text { streamgage }\end{array}$ & $n$ & CONTDA & $\begin{array}{c}\text { Nonexceedance } \\
\text { percentile } 1 \text { for } \\
\text { CONTDA }\end{array}$ & $E L_{6000}$ & $\begin{array}{c}\text { Nonexceedance } \\
\text { percentile }{ }^{1} \text { for } \\
E L_{6000}\end{array}$ \\
\hline 219 & 06122000 & $\begin{array}{l}\text { American Fork below Lebo Creek, near } \\
\text { Harlowton, Montana }\end{array}$ & 46.3962 & -109.7421 & CONT & 23 & 171 & 78.0 & 13.2 & 44.0 \\
\hline 245 & 06129100 & $\begin{array}{l}\text { North Fork McDonald Creek tributary near } \\
\text { Heath, Montana }\end{array}$ & 47.0684 & -109.2137 & CSG & 16 & 2.72 & 15.4 & 0.0 & 1.1 \\
\hline 246 & 06129200 & Alkali Creek near Heath, Montana & 47.0790 & -109.1479 & CSG & 15 & 3.78 & 18.7 & 0.0 & 1.1 \\
\hline 247 & 06129400 & $\begin{array}{l}\text { South Fork McDonald Creek tributary near } \\
\text { Grass Range, Montana }\end{array}$ & 47.0054 & -108.7911 & CSG & 15 & 0.70 & 3.3 & 0.0 & 1.1 \\
\hline 426 & 06193000 & Shields River near Wilsall, Montana & 46.1526 & -110.5868 & CONT & 22 & 90.9 & 62.6 & 88.6 & 83.5 \\
\hline 430 & 06197000 & Big Timber Creek near Big Timber, Montana & 45.9543 & -110.0295 & CONT & 13 & 75.3 & 59.3 & 56.0 & 69.2 \\
\hline 435 & 06201550 & $\begin{array}{l}\text { Yellowstone River tributary near Greycliff, } \\
\text { Montana }\end{array}$ & 45.7343 & -109.7151 & CSG & 15 & 2.62 & 13.2 & 0.0 & 1.1 \\
\hline 436 & 06201600 & Bridger Creek near Greycliff, Montana & 45.6914 & -109.7163 & CSG & 16 & 61.3 & 57.1 & 10.9 & 41.8 \\
\hline 437 & 06201650 & Work Creek near Reed Point, Montana & 45.7031 & -109.6251 & CSG & 16 & 32.4 & 38.5 & 0.0 & 1.1 \\
\hline 440 & 06202510 & $\begin{array}{l}\text { Stillwater River above Nye Creek, near Nye, } \\
\text { Montana }\end{array}$ & 45.3943 & -109.8695 & CONT & 12 & 192 & 80.2 & 96.2 & 89.0 \\
\hline 446 & 06207600 & Jack Creek tributary near Belfry, Montana & 45.1622 & -108.8240 & CSG & 17 & 0.97 & 4.4 & 0.0 & 1.1 \\
\hline 447 & 06207800 & Bluewater Creek near Bridger, Montana & 45.3314 & -108.8015 & CONT & 12 & 28.1 & 37.4 & 0.5 & 33.0 \\
\hline 451 & 06210000 & $\begin{array}{l}\text { West Fork Rock Creek below Basin Creek, } \\
\text { near Red Lodge, Montana }\end{array}$ & 45.1545 & -109.3674 & CONT & 19 & 51.1 & 52.7 & 100.0 & 95.6 \\
\hline 459 & 06215000 & Pryor Creek above Pryor, Montana & 45.3507 & -108.5660 & CONT & 12 & 44.1 & 46.2 & 50.9 & 63.7 \\
\hline 462 & 06216300 & West Buckeye Creek near Billing, Montana & 45.6498 & -108.3923 & CSG & 20 & 2.71 & 14.3 & 0.0 & 1.1 \\
\hline 471 & 06287500 & Soap Creek near St. Xavier, Montana & 45.3269 & -107.7698 & CONT & 22 & 94.4 & 64.8 & 4.2 & 35.2 \\
\hline 472 & 06288000 & Rotten Grass Creek near St. Xavier, Montana & 45.4122 & -107.6831 & CONT & 10 & 146 & 73.6 & 8.1 & 39.6 \\
\hline 473 & 06288200 & Beauvais Creek near St. Xavier, Montana & 45.4770 & -108.0080 & CONT & 11 & 123 & 71.4 & 0.2 & 31.9 \\
\hline 478 & 06290200 & $\begin{array}{l}\text { Little Bighorn River tributary near Wyola, } \\
\text { Montana }\end{array}$ & 45.1393 & -107.3889 & CSG & 14 & 4.45 & 20.9 & 0.0 & 1.1 \\
\hline 480 & 06291000 & Owl Creek near Lodge Grass, Montana & 45.2680 & -107.3014 & CONT & 20 & 163 & 76.9 & 0.0 & 1.1 \\
\hline
\end{tabular}

${ }^{1}$ The nonexceedance percentile for the basin or climatic variable value was calculated in relation to the values for all streamgages included in the regional regression analyses for the indicated hydrologic region. 

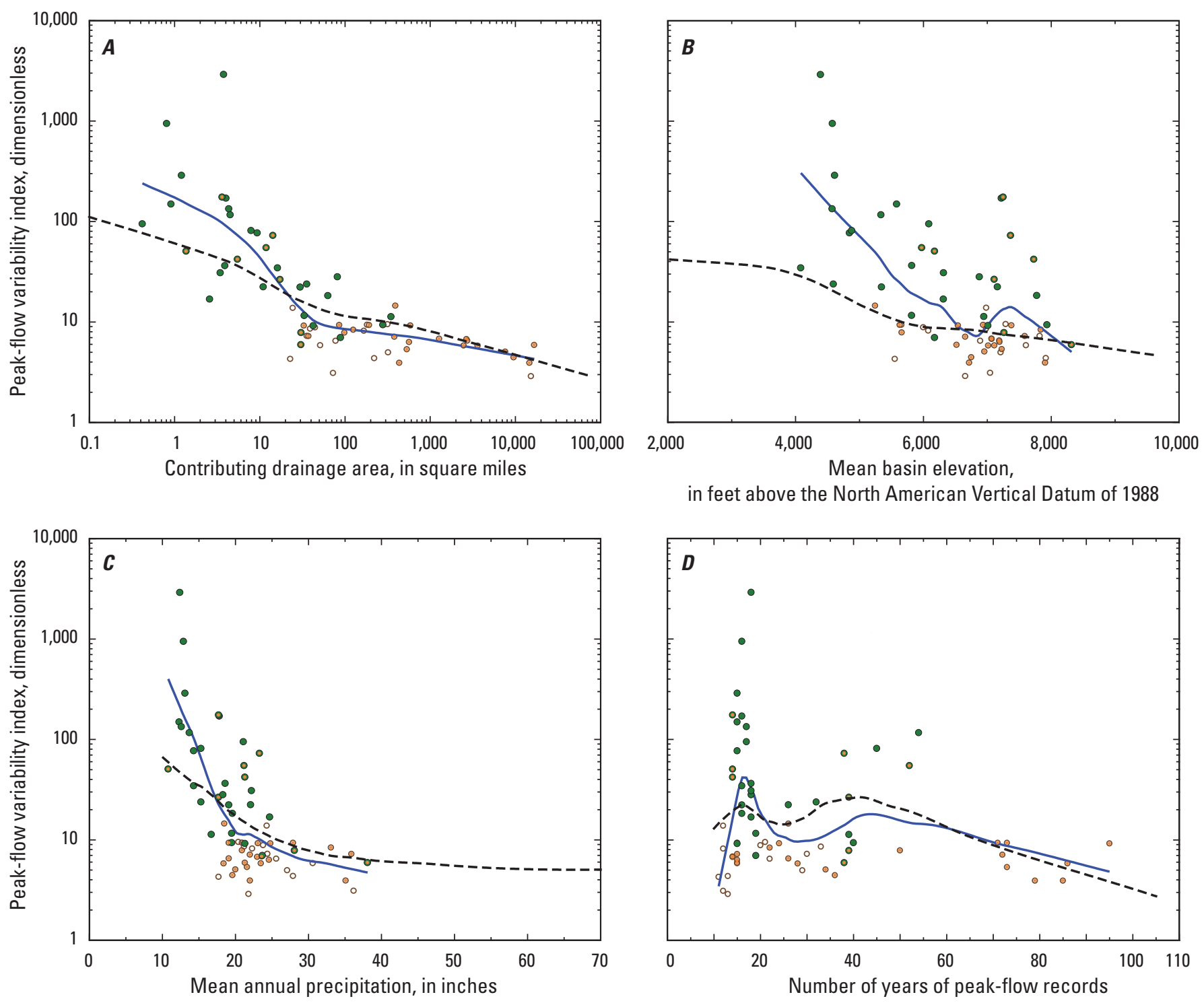

in feet above the North American Vertical Datum of 1988

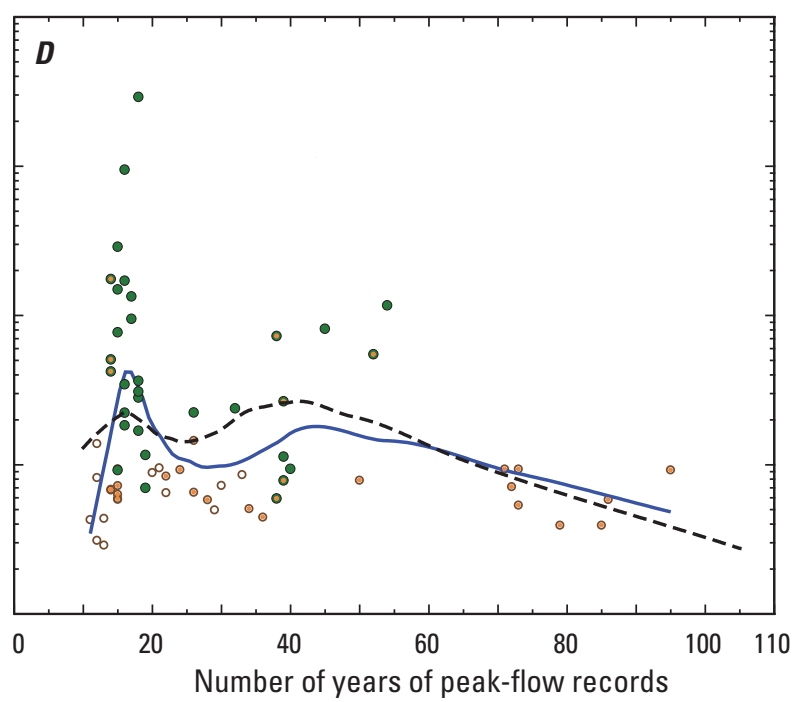

EXPLANATION

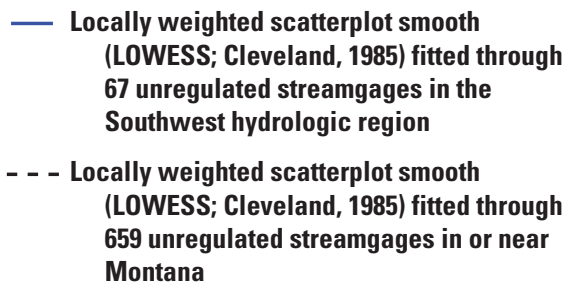

- Crest-stage streamgage

- Continuous streamgage

- Interior dot denotes active streamgage in water year 2017 659 unregulated streamgages in or near Montana

Figure 27. Relations between peak-flow variability index and contributing drainage area, mean basin elevation, mean annual precipitation, and years of peak-flow records for 67 unregulated streamgages in the Southwest hydrologic region. $A$, Peak-flow variability and contributing drainage area relations. $B$, Peak-flow variability and mean basin elevation relations. $C$, Peak-flow variability and mean annual precipitation relations. $D$, Peak-flow variability and years of peak-flow records relations. 


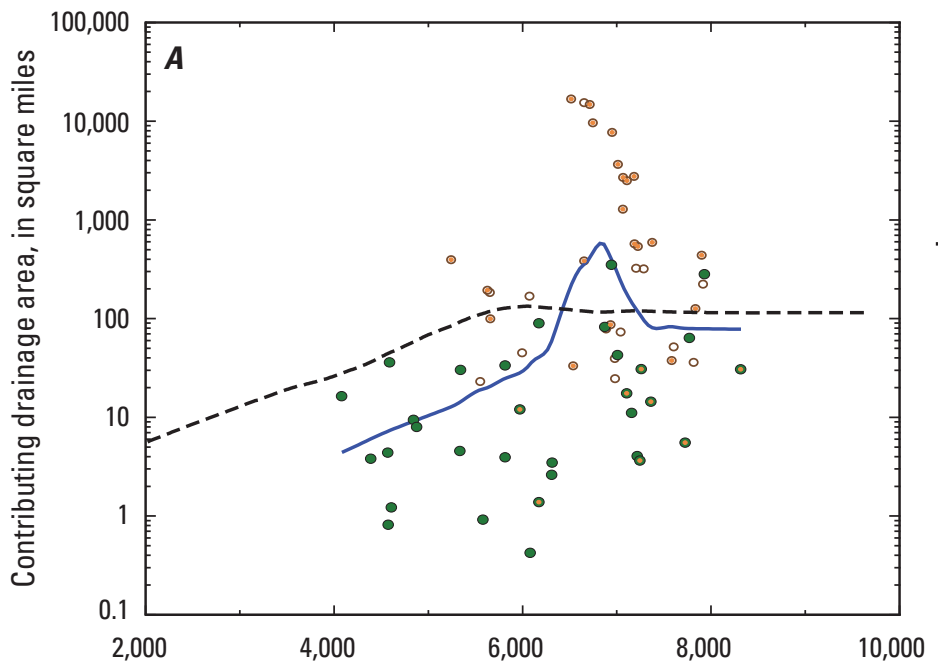

\section{EXPLANATION}

Locally weighted scatterplot smooth (LOWESS; Cleveland, 1985) fitted through

67 unregulated streamgages in the Southwest hydrologic region

- - - Locally weighted scatterplot smooth (LOWESS; Cleveland, 1985) fitted through 659 unregulated streamgages in or near Montana

- Crest-stage streamgage

- Continuous streamgage

Interior dot denotes active streamgage in water year 2017

Mean basin elevation, in feet above the North American Vertical Datum of 1988
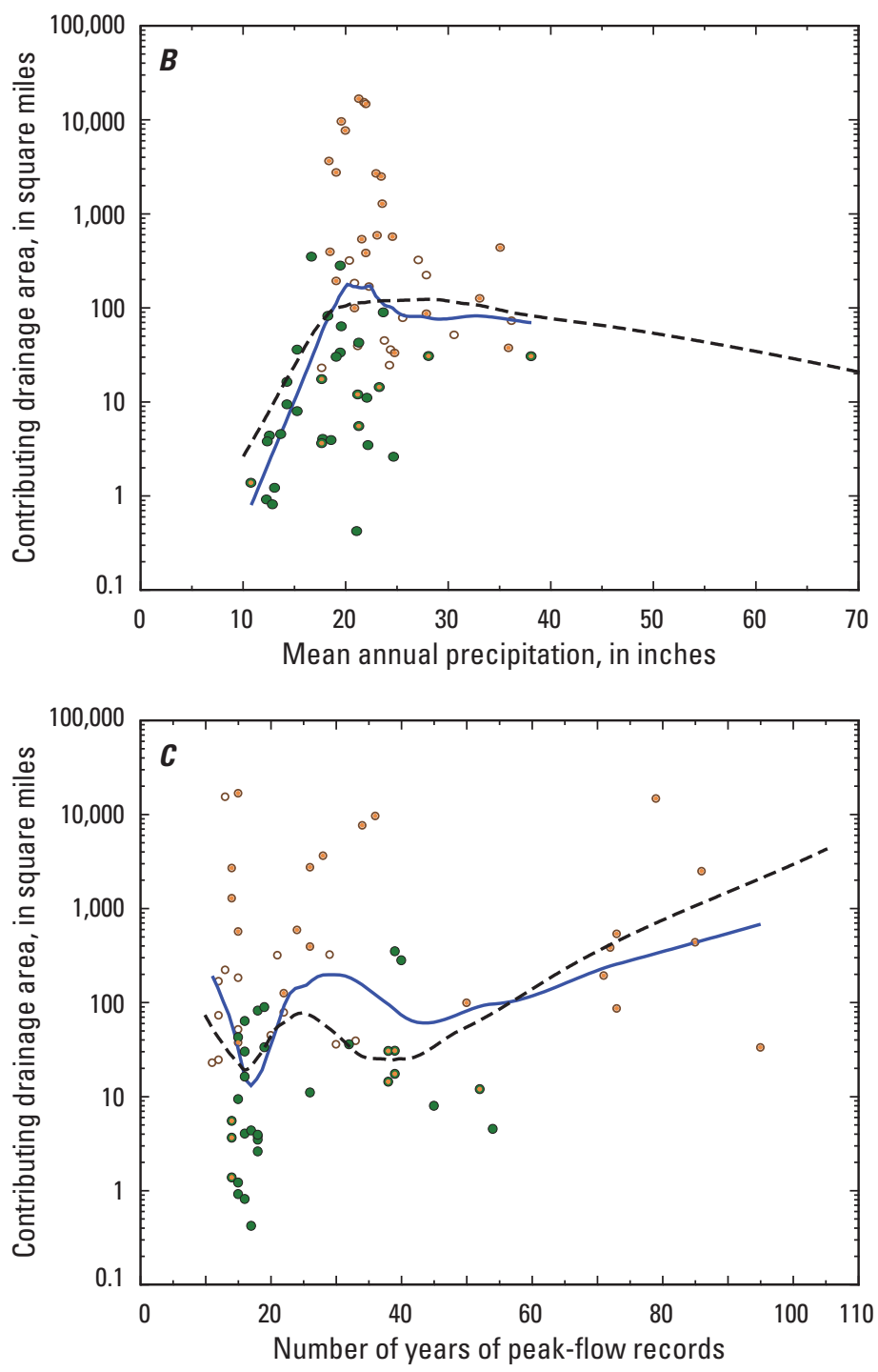

Figure 28. Relations between contributing drainage area and mean basin elevation, mean annual precipitation, and years of peak-flow records for 67 unregulated streamgages in the Southwest hydrologic region. $A$, Contributing drainage area and mean basin elevation relations. $B$, Contributing drainage area and mean annual precipitation relations. $C$, Contributing drainage area and years of peak-flow records relations. 
and ranks as the sixth largest median PFVI among the eight hydrologic regions. A major factor contributing to low peakflow variability in the Southwest hydrologic region might be the dominance of snowmelt runoff in the annual hydrograph of many of the streamgages. For unregulated streamgages in the Southwest hydrologic region, fall and winter (OctoberFebruary) precipitation accounts for 24.8 percent of annual precipitation (table 8), which can result in large accumulated snowpacks (Sando and McCarthy, 2018) that contribute to streamflows during the typical snowmelt runoff period of May through mid-July. May-June precipitation accounts for about 32.6 percent of annual precipitation (table 8 ), which ranks sixth among the hydrologic regions, and July-August precipitation accounts for 18.6 percent of annual precipitation, which ranks fifth among the eight hydrologic regions. In the Southwest hydrologic region, annual peak flows predominantly are in May and June (fig. 2 of Sando, R., and others, 2018). Dominance of snowmelt in the annual hydrograph tends to provide temporal integration of a substantial part of the annual precipitation inputs and contributes to the low PFVIs for streamgages in the Southwest hydrologic region.

About 17.2 percent of the streamgages in the Southwest hydrologic region are considered to have mixed-population characteristics (table 1) that result in a small number of unusually large peak flows that are substantially larger than the main body of peak flows. Typically, the unusually large peak-flow events result from extremely intense rainfall events in May and June. Mixed-population peak-flow datasets often are in streamgages with headwaters on or near the Continental Divide. In the Southwest hydrologic region, the mixed-population streamgages predominantly are located in a generally small area west of the Missouri River in the northern part of the hydrologic region. Most (8 out of 11) of the mixed-population streamgages in the Southwest hydrologic region that were included in the regional regression analysis (Sando, R., and others, 2018) had positive residuals for the 1-percent AEP regression; however, none of those mixedpopulation streamgages had significant influence. Among the candidate explanatory variables included in the regional regression analyses, there are no variables that represent spatial variability in precipitation intensity (such as indices of the 100-year 24-hour precipitation; for example, U.S. Weather Bureau, 1961). Inclusion of variables that represent spatial variability in precipitation intensity might help address some mixed-population issues and improve potential future regional regression analyses in the Southwest hydrologic region.

The CDFs of selected basin characteristics (drainage area, mean basin elevation, and mean annual precipitation) for the road and stream intersections and for the streamgages in the Southwest hydrologic region are shown in figure 29. With respect to drainage area, the CDF of road and stream intersections for the Southwest hydrologic region generally is similar to the $\mathrm{CDF}$ of road and stream intersections for all of Montana (fig. 29A). In the Southwest hydrologic region, the CDF of streamgages diverges from the CDF of road and stream intersections in the range of drainage areas less than about $30 \mathrm{mi}^{2}$ and in that range, the CDF of streamgages in the Southwest hydrologic region diverges from the $\mathrm{CDF}$ of streamgages for all of Montana; thus, streamgages with drainage areas in that range are considered to be underrepresented in the Southwest hydrologic region.

The Southwest hydrologic region generally is higher in elevation than Montana as a whole. Mean basin elevation for road and stream intersections in the Southwest hydrologic region ranges from 3,618 to 9,974 ft (Dutton and others, 2021) with a median of $6,347 \mathrm{ft}$ (table 4 ). The range for the Southwest hydrologic region is smaller than for all of Montana (1,951-9,974 ft; Dutton and others, 2021) and the median for the Southwest hydrologic region is substantially higher than for all of Montana (4,173 ft; table 4). There are substantial differences between the CDFs of road and stream intersections for the Southwest hydrologic region relative to the CDFs of road and stream intersections for all of Montana (fig. 29B). In the Southwest hydrologic region, the CDF of streamgages diverges from the $\mathrm{CDF}$ of road and stream intersections in the range of mean basin elevations from about 5,000 to $6,800 \mathrm{ft}$, indicating underrepresentation in that range.

The Southwest hydrologic region is somewhat wetter than Montana as a whole. Mean annual precipitation for road and stream intersections in the Southwest hydrologic region ranges from 9.5 to 47.6 inches (Dutton and others, 2021) with a median of 18.4 inches (table 5). The range for the Southwest hydrologic region is smaller than for all of Montana (8.4-91.3 inches; Dutton and others, 2021) and the median for the Southwest hydrologic region is somewhat larger than for all of Montana (15.7 inches; table 5). The Southwest hydrologic region has a somewhat lower proportion of road and stream intersections with mean annual precipitation from about 15 to 18 inches than Montana as a whole (fig. 29C). In the Southwest hydrologic region, the CDF of streamgages diverges from the CDF of road and stream intersections in the range of mean annual precipitation from about 12 to 17 inches, indicating underrepresentation in that range.

The explanatory variables for the Southwest hydrologic region RREs are CONTDA and $E L_{6000}$ (table 6). The 1-percent AEP RRE for the Southwest hydrologic region has an SEP of 73.8 percent, which is higher than the area-weighted mean SEP for all hydrologic regions in Montana (63.3 percent; table 6). For the 1-percent AEP regression for the Southwest hydrologic region, 10.4 percent of the streamgages have significant leverage and 4.2 percent of the streamgages have significant influence (table 7). The significant leverage percentage is similar to the significant leverage percentage for all of the streamgages in Montana used in the regional regression analyses (8.2 percent; table 7) and the significant influence percentage is smaller than the significant influence percentage for all of the streamgages in Montana used in the regional regression analyses (10.4 percent; table 7).

Information on streamgages in the Southwest hydrologic region with significant leverage and influence is presented in table 26. One of the six significant leverage streamgages has the largest CONTDA value (nonexceedance percentile 


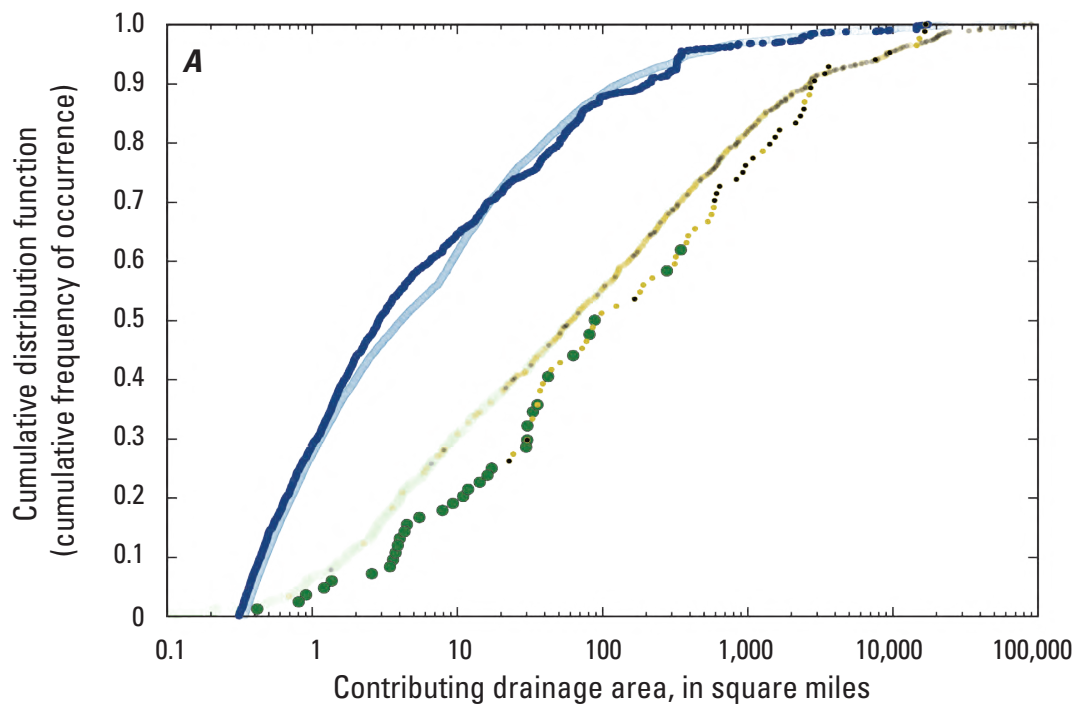

\section{EXPLANATION}

Road and stream intersection in the Southwest hydrologic region

One of 12,639 road and stream intersections in Montana, as shown in figure 5-Open symbols appear as solid symbols because of the high data density

Regulated and unregulated streamgages in the Southwest hydrologic region

- Crest-stage streamgage

Unregulated continuous streamgage

- Regulated continuous streamgage

Regulated and unregulated streamgages in or near Montana, as shown in figure 5

Crest-stage streamgage in or near Montana Unregulated streamgages in or near Montana

Regulated streamgages in or near Montana

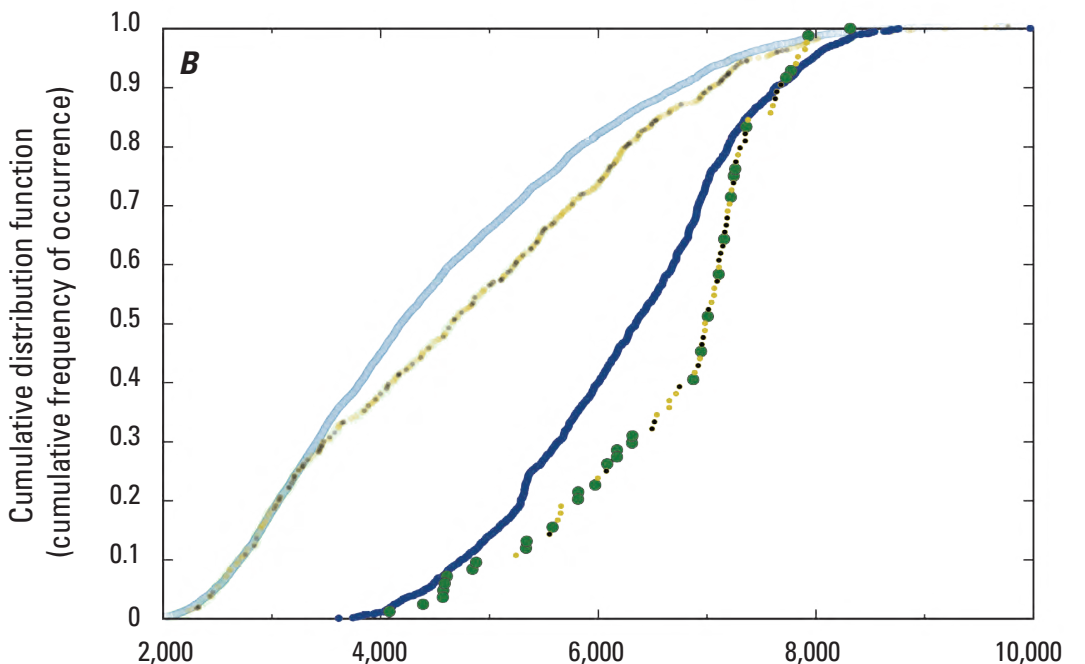

Mean basin elevation, in feet above the North American Vertical Datum of 1988

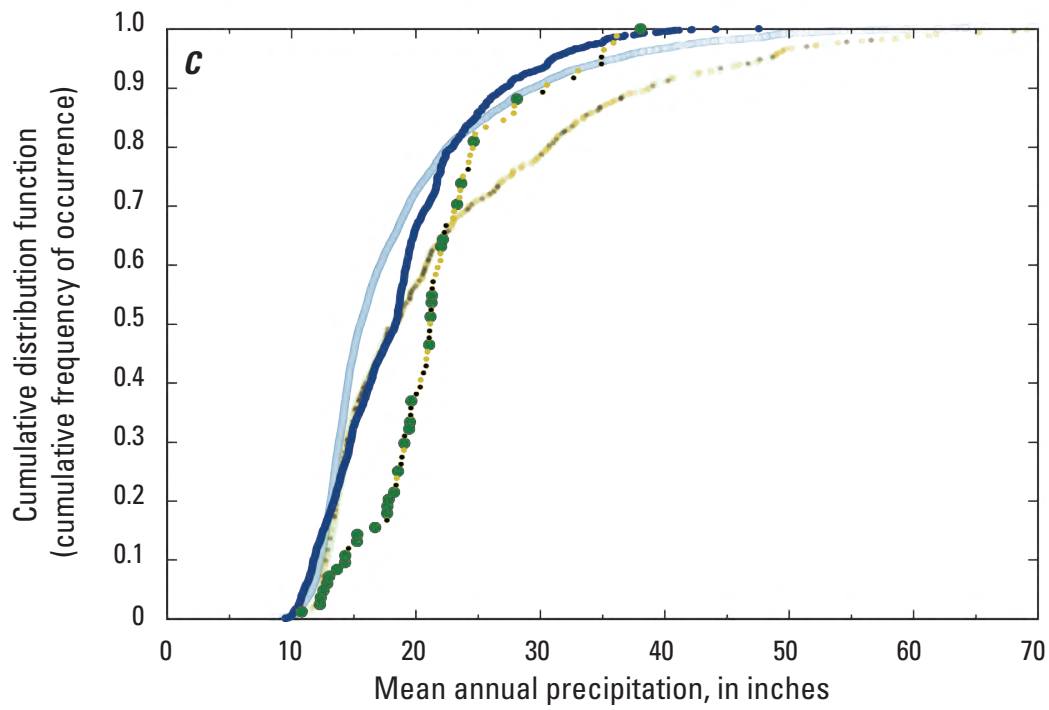

Figure 29. Cumulative distribution functions of selected drainage-basin characteristics for 2,267 road and stream intersections and for 84 streamgages (regulated and unregulated) in the Southwest hydrologic region. $A$, Contributing drainage area relations. $B$, Mean basin elevation relations. $C$, Mean annual precipitation relations. 
equal to 100 percent) and one of the six significant leverage streamgages has a small CONTDA value (nonexceedance percentile less than about 2 percent). Three of the six significant leverage streamgages have low $E L_{6000}$ values (nonexceedance percentiles less than about 8 percent). One of the six significant leverage streamgages has a low $E L_{6000}$ value (nonexceedance percentiles less than about 11 percent) in association with a small CONTDA value (nonexceedance percentile less than about 15 percent). The three streamgages with significant influence vary with respect to the residuals for the 1-percent AEP RRE; one of the streamgages has a negative residual, and two have positive residuals. The streamgage with both significant leverage and significant influence has a positive residual.

In general, the streamgage network in the Southwest hydrologic region is considered to provide reasonable representation of the hydroclimatic settings of that hydrologic region. The RREs of the Southwest hydrologic region are considered to be reasonably reliable. Possible shortcomings of the streamgage network in the Southwest hydrologic region include small underrepresentation of basins with drainage areas less than about $30 \mathrm{mi}^{2}$, mean elevation from about 5,000 to $6,800 \mathrm{ft}$, and (or) mean annual precipitation from 12 to 17 inches. Future improvements to the streamgage network in the Southwest hydrologic region might include establishing new CSGs or reactivating discontinued streamgages as CSGs on drainage basins with the specified characteristics. Information on discontinued streamgages in the Southwest hydrologic region that might be candidates for reactivation to improve the streamgage network is presented in table 27.

\section{Synopsis of Possible Shortcomings of and Future Improvements to the Streamgaging Network in Montana}

This section describes possible shortcomings of and future improvements to the streamgage network. The descriptions are provided by hydrologic region.

\section{Synopsis for the West Hydrologic Region}

The median $P F V I$ value for unregulated streamgages in the West hydrologic region (7.63, table 3) ranks as the seventh largest among the eight hydrologic regions. The 1-percent AEP RRE for the West hydrologic region has an SEP of 56.0 percent (table 6), which ranks sixth largest among the eight hydrologic regions. The 41 active unregulated streamgages (with no CSGs; table 3) represent an areal density of 0.00192 streamgage per $\mathrm{mi}^{2}$ (ranking second largest among hydrologic regions) and a density of 0.01723 streamgage per road and stream intersection (ranking fifth among hydrologic regions). These various characteristics might indicate that the streamgage network in the West hydrologic region has a smaller need for improvements than most of the other hydrologic regions.
The indicated possible shortcomings of the streamgage network in the West hydrologic region include no active CSGs, and possible underrepresentation of basins with drainage area less than about $5 \mathrm{mi}^{2}$, mean elevation less than about $4,000 \mathrm{ft}$, and (or) mean annual precipitation less than about 25 inches. The lack of active CSGs might contribute to poor understanding of effects of future climatic variability on small drainage basins in the West hydrologic region. Intuitively, the streamgage network in the West hydrologic region might benefit from establishing a CSG on a basin with the specified characteristics.

About 12.5 percent of the streamgages in the West hydrologic region are considered to have mixed-population characteristics (table 1). Identification and treatment of mixedpopulation datasets are specifically noted in Bulletin 17C (England and others, 2019) as a topic needing further study. Potential future advances in understanding and treatment of mixed-population datasets in frequency analysis might contribute to improvements in frequency analyses in the West hydrologic region. Among the candidate explanatory variables included in the regional regression analyses, there are no variables that represent spatial variability in precipitation intensity (such as indices of the 100-year 24-hour precipitation; for example, U.S. Weather Bureau, 1961). Inclusion of variables that represent spatial variability in precipitation intensity might help address some mixed-population issues and improve potential future regional regression analyses in the West hydrologic region.

\section{Synopsis for the Northwest hydrologic region}

The median PFVI value for streamgages in the Northwest hydrologic region (6.04, table 3$)$ ranks as the eighth largest among the eight hydrologic regions. The 1-percent AEP RRE for the Northwest hydrologic region has an SEP of 13.6 percent (table 6), which ranks eighth largest among the eight hydrologic regions. The RREs for the Northwest hydrologic region were developed using weighted least squares regression to better handle complexities introduced by the large proportion of mixed-population peak-flow datasets (Sando, R., and others, 2018); the use of weighted least squares regression might contribute to the low SEP. The 12 active unregulated streamgages (including 1 CSG; table 3) represent an areal density of 0.00151 streamgage per $\mathrm{mi}^{2}$ (ranking fifth largest among hydrologic regions) and a density of 0.03371 streamgage per road and stream intersection (ranking first among hydrologic regions). These various characteristics might indicate that the streamgage network in the Northwest hydrologic region has a smaller need for improvements than most of the other hydrologic regions.

The indicated possible shortcomings of the streamgage network in the Northwest hydrologic region include possible underrepresentation of basins with drainage area less than about $125 \mathrm{mi}^{2}$, mean basin elevation less than about 5,400 ft, and (or) mean annual precipitation less than about 37 inches. 
Table 26. Information on streamgages in the Southwest hydrologic region with significant leverage and influence in the Montana regional regression analyses (Sando, R., and others, 2018).

[ID, identification; NAD 83, North American Datum of $1983 ; n$, total number of years of peak-flow records; $C O N T D A$, contributing drainage area, in square miles; $E L_{6000}$, percentage of basin above 6,000 feet elevation; AEP, annual exceedance probability; CONT, continuous streamgage; CSG, crest-stage gage]

\begin{tabular}{|c|c|c|c|c|c|c|c|c|c|c|c|c|c|c|}
\hline \multirow{2}{*}{$\begin{array}{c}\text { Map } \\
\text { number } \\
\text { (fig. 1) }\end{array}$} & \multirow{2}{*}{$\begin{array}{l}\text { Streamgage } \\
\text { ID number }\end{array}$} & \multirow{2}{*}{$\begin{array}{c}\text { Streamgage } \\
\text { name }\end{array}$} & \multirow{2}{*}{$\begin{array}{l}\text { Latitude, } \\
\text { in decimal } \\
\text { degrees } \\
\text { (NAD 83) }\end{array}$} & \multirow{2}{*}{$\begin{array}{l}\text { Longitude, } \\
\text { in decimal } \\
\text { degrees } \\
\text { (NAD 83) }\end{array}$} & \multirow{2}{*}{$\begin{array}{c}\text { Type of } \\
\text { streamgage }\end{array}$} & \multirow{2}{*}{$\begin{array}{c}\text { Status of } \\
\text { streamgage } \\
\text { in water } \\
\text { year } 2017\end{array}$} & \multirow[t]{2}{*}{$n$} & \multirow{2}{*}{ CONTDA } & \multirow{2}{*}{$\begin{array}{c}\text { Non- } \\
\text { exceedance } \\
\text { percentile }{ }^{1} \\
\text { for CONTDA }\end{array}$} & \multirow{2}{*}{$E L_{6000}$} & \multirow{2}{*}{$\begin{array}{l}\text { Non- } \\
\text { exceedance } \\
\text { percentile } \\
\text { for } E L_{6000}\end{array}$} & \multicolumn{3}{|c|}{$\begin{array}{c}\text { Regression residuals for } \\
\text { the specified AEP } \\
\text { regression analyses }\end{array}$} \\
\hline & & & & & & & & & & & & $\begin{array}{c}\text { 10-percent } \\
\text { AEP }\end{array}$ & $\begin{array}{c}\text { 4-percent } \\
\text { AEP }\end{array}$ & $\begin{array}{c}\text { 1-percent } \\
\text { AEP }\end{array}$ \\
\hline \multicolumn{15}{|c|}{ Streamgages with significant leverage } \\
\hline 45 & 06025500 & $\begin{array}{l}\text { Big Hole } \\
\text { River near } \\
\text { Melrose, } \\
\text { Montana }\end{array}$ & 45.5266 & -112.7017 & CONT & Active & 92 & 2,472 & 100.0 & 92.04 & 73.0 & 0.231 & 0.253 & 0.270 \\
\hline 58 & ${ }^{2} 06034700$ & $\begin{array}{l}\text { Sand Creek at } \\
\text { Sappington, } \\
\text { Montana }\end{array}$ & 45.7914 & -111.7555 & CSG & Discontinued & 15 & 9.34 & 16.7 & 0.00 & 2.7 & 0.217 & 0.249 & 0.271 \\
\hline 96 & 06058700 & $\begin{array}{l}\text { Mitchell } \\
\text { Gulch } \\
\text { near East } \\
\text { Helena, } \\
\text { Montana }\end{array}$ & 46.5713 & -111.8235 & CSG & Discontinued & 45 & 7.93 & 14.6 & 7.54 & 10.8 & 0.032 & 0.041 & 0.015 \\
\hline 102 & 06062700 & $\begin{array}{l}\text { Little } \\
\text { Porcupine } \\
\text { Creek } \\
\text { tributary } \\
\text { near } \\
\text { Helena, } \\
\text { Montana }\end{array}$ & 46.5879 & -112.2701 & CSG & Discontinued & 17 & 0.42 & 2.1 & 58.08 & 45.9 & 0.026 & -0.017 & -0.004 \\
\hline 110 & 06071400 & $\begin{array}{l}\text { Dog Creek } \\
\text { near Craig, } \\
\text { Montana }\end{array}$ & 47.0865 & -111.9936 & $\mathrm{CSG}$ & Discontinued & 16 & 16.2 & 25.0 & 0.00 & 2.7 & 0.202 & 0.179 & 0.170 \\
\hline 111 & 06071600 & $\begin{array}{l}\text { Wegner Creek } \\
\text { at Craig, } \\
\text { Montana }\end{array}$ & 47.0762 & -111.9555 & CSG & Discontinued & 32 & 35.7 & 41.7 & 0.68 & 8.1 & -0.106 & -0.156 & -0.196 \\
\hline
\end{tabular}


Table 26. Information on streamgages in the Southwest hydrologic region with significant leverage and influence in the Montana regional regression analyses (Sando, R., and others, 2018).-Continued

[ID, identification; NAD 83, North American Datum of 1983; $n$, total number of years of peak-flow records; $C O N T D A$, contributing drainage area, in square miles; $E L_{6000}$, percentage of basin above 6,000 feet elevation; AEP, annual exceedance probability; CONT, continuous streamgage; CSG, crest-stage gage]

\begin{tabular}{|c|c|c|c|c|c|c|c|c|c|c|c|c|c|c|}
\hline \multirow{2}{*}{$\begin{array}{c}\text { Map } \\
\text { number } \\
\text { (fig. 1) }\end{array}$} & \multirow{2}{*}{$\begin{array}{l}\text { Streamgage } \\
\text { ID number }\end{array}$} & \multirow{2}{*}{$\begin{array}{c}\text { Streamgage } \\
\text { name }\end{array}$} & \multirow{2}{*}{$\begin{array}{l}\text { Latitude, } \\
\text { in decimal } \\
\text { degrees } \\
\text { (NAD 83) }\end{array}$} & \multirow{2}{*}{$\begin{array}{l}\text { Longitude, } \\
\text { in decimal } \\
\text { degrees } \\
\text { (NAD 83) }\end{array}$} & \multirow{2}{*}{$\begin{array}{c}\text { Type of } \\
\text { streamgage }\end{array}$} & \multirow{2}{*}{$\begin{array}{c}\text { Status of } \\
\text { streamgage } \\
\text { in water } \\
\text { year } 2017\end{array}$} & \multirow[t]{2}{*}{$n$} & \multirow[t]{2}{*}{ CONTDA } & \multirow{2}{*}{$\begin{array}{c}\text { Non- } \\
\text { exceedance } \\
\text { percentile }{ }^{1} \\
\text { for CONTDA }\end{array}$} & \multirow{2}{*}{$E L_{6000}$} & \multirow{2}{*}{$\begin{array}{l}\text { Non- } \\
\text { exceedance } \\
\text { percentile } \\
\text { for } E L_{6000}\end{array}$} & \multicolumn{3}{|c|}{$\begin{array}{c}\text { Regression residuals for } \\
\text { the specified AEP } \\
\text { regression analyses }\end{array}$} \\
\hline & & & & & & & & & & & & $\begin{array}{c}\text { 10-percent } \\
\text { AEP }\end{array}$ & $\begin{array}{c}\text { 4-percent } \\
\text { AEP }\end{array}$ & $\begin{array}{c}\text { 1-percent } \\
\text { AEP }\end{array}$ \\
\hline \multicolumn{15}{|c|}{ Streamgages with significant influence } \\
\hline 43 & 06025100 & $\begin{array}{l}\text { Quartz Hill } \\
\text { Gulch near } \\
\text { Wise River, } \\
\text { Montana }\end{array}$ & 45.7764 & -112.8619 & CSG & Active & 43 & 14.3 & 22.9 & 95.27 & 81.1 & -0.794 & -0.692 & -0.548 \\
\hline 53 & 06030300 & $\begin{array}{l}\text { Jefferson } \\
\text { River } \\
\text { tributary } \\
\text { No. } 2 \text { near } \\
\text { Whitehall, } \\
\text { Montana }\end{array}$ & 45.8803 & -111.9743 & CSG & Discontinued & 55 & 4.51 & 12.5 & 23.42 & 16.2 & 0.352 & 0.520 & 0.704 \\
\hline 58 & ${ }^{2} 06034700$ & $\begin{array}{l}\text { Sand Creek at } \\
\text { Sappington, } \\
\text { Montana }\end{array}$ & 45.7914 & -111.7555 & CSG & Discontinued & 15 & 9.34 & 16.7 & 0.00 & 2.7 & 0.217 & 0.249 & 0.271 \\
\hline
\end{tabular}

${ }^{1}$ The nonexceedance percentile for the basin or climatic variable value was calculated in relation to the values for all streamgages included in the regional regression analyses for the indicated hydrologic region.

${ }^{2}$ Streamgages having both significant leverage and significant influence. 
Table 27. Information on discontinued streamgages in the Southwest hydrologic region that might be candidates for reactivation to improve the streamgage network.

[NAD 83, North American Datum of $1983 ; n$, total number of years of peak-flow records; CONTDA, contributing drainage area, in square miles; $E L_{6000}$, percentage of basin above 6,000 feet elevation CSG, crest-stage gage; CONT, continuous streamgage]

\begin{tabular}{|c|c|c|c|c|c|c|c|c|c|c|}
\hline $\begin{array}{l}\text { Map } \\
\text { number } \\
\text { (fig. 1) }\end{array}$ & $\begin{array}{c}\text { Station } \\
\text { identification } \\
\text { number }\end{array}$ & Station name & $\begin{array}{l}\text { Latitude, } \\
\text { in decimal } \\
\text { degrees } \\
\text { (NAD 83) }\end{array}$ & $\begin{array}{c}\text { Longitude, } \\
\text { in decimal } \\
\text { degrees } \\
\text { (NAD 83) }\end{array}$ & $\begin{array}{c}\text { Type of } \\
\text { streamgage }\end{array}$ & $n$ & CONTDA & $\begin{array}{c}\text { Nonexceedance } \\
\text { percentile }{ }^{1} \text { for } \\
\text { CONTDA }\end{array}$ & $E L_{6000}$ & $\begin{array}{c}\text { Nonexceedance } \\
\text { percentile }{ }^{1} \text { for } \\
E L_{6000}\end{array}$ \\
\hline 18 & 06013200 & Traux Creek near Lima, Montana & 44.6175 & -112.5674 & CSG & 16 & 4.02 & 10.4 & 100.0 & 77.1 \\
\hline 19 & 06013400 & Muddy Creek near Dell, Montana & 44.6395 & -112.8094 & CSG & 16 & 63.1 & 56.3 & 100.0 & 77.1 \\
\hline 29 & 06017500 & Blacktail Deer Creek near Dillon, Montana & 45.0461 & -112.5497 & CONT & 21 & 316 & 81.3 & 95.7 & 64.6 \\
\hline 32 & 06019400 & Sweetwater Creek near Alder, Montana & 45.0774 & -112.2263 & CSG & 18 & 81.6 & 62.5 & 99.9 & 75.0 \\
\hline 40 & 06024500 & Trail Creek near Wisdom, Montana & 45.6564 & -113.7167 & CONT & 12 & 72.6 & 58.3 & 100.0 & 77.1 \\
\hline 42 & 06024590 & Wise River near Wise River, Montana & 45.7046 & -113.0316 & CONT & 13 & 221 & 77.1 & 100.0 & 77.1 \\
\hline 44 & 06025300 & Moose Creek near Divide, Montana & 45.7136 & -112.7053 & CSG & 15 & 42.4 & 50.0 & 94.7 & 60.4 \\
\hline 54 & 06030500 & $\begin{array}{l}\text { Boulder River above Rock Creek, near Basin, } \\
\text { Montana }\end{array}$ & 46.2543 & -112.5009 & CONT & 12 & 24.4 & 29.2 & 100.0 & 77.1 \\
\hline 58 & 06034700 & Sand Creek at Sappington, Montana & 45.7914 & -111.7555 & CSG & 15 & 9.34 & 16.7 & 0.0 & 2.1 \\
\hline 74 & 06040300 & Jack Creek near Ennis, Montana & 45.3563 & -111.5816 & CONT & 15 & 51.3 & 54.2 & 97.9 & 66.7 \\
\hline 91 & 06055500 & Crow Creek near Radersburg, Montana & 46.2623 & -111.6871 & CONT & 22 & 77.9 & 60.4 & 82.3 & 45.8 \\
\hline 92 & 06056200 & Castle Creek tributary near Ringling, Montana & 46.3585 & -111.0968 & CSG & 18 & 2.59 & 4.2 & 84.1 & 47.9 \\
\hline 94 & 06056600 & $\begin{array}{l}\text { Deep Creek below North Fork Deep Creek, } \\
\text { near Townsend, Montana }\end{array}$ & 46.3247 & -111.2935 & CSG & 19 & 88.9 & 66.7 & 52.7 & 31.3 \\
\hline 98 & 06061700 & Jackson Creek near East Helena, Montana & 46.4718 & -111.8531 & CSG & 18 & 3.45 & 6.3 & 58.0 & 33.3 \\
\hline 99 & 06061800 & Crystal Creek near East Helena, Montana & 46.4832 & -111.8610 & CSG & 18 & 3.90 & 8.3 & 32.3 & 20.8 \\
\hline 100 & 06061900 & McClellan Creek near East Helena, Montana & 46.5331 & -111.8791 & CSG & 19 & 33.3 & 39.6 & 33.7 & 22.9 \\
\hline 102 & 06062700 & $\begin{array}{l}\text { Little Porcupine Creek tributary near Helena, } \\
\text { Montana }\end{array}$ & 46.5879 & -112.2701 & CSG & 17 & 0.42 & 2.1 & 58.1 & 35.4 \\
\hline 106 & 06068500 & $\begin{array}{l}\text { Little Prickly Pear Creek near Marysville, } \\
\text { Montana }\end{array}$ & 46.7877 & -112.4067 & CONT & 20 & 44.6 & 52.1 & 46.1 & 29.2 \\
\hline 107 & 06071000 & $\begin{array}{l}\text { Little Prickly Pear Creek near Canyon Creek, } \\
\text { Montana }\end{array}$ & 46.8189 & -112.2505 & CONT & 15 & 182 & 72.9 & 31.7 & 18.8 \\
\hline 108 & 06071200 & Lyons Creek near Wolf Creek, Montana & 46.9394 & -112.1264 & CSG & 16 & 29.9 & 31.3 & 23.6 & 14.6 \\
\hline 110 & 06071400 & Dog Creek near Craig, Montana & 47.0865 & -111.9936 & $\mathrm{CSG}$ & 16 & 16.2 & 25.0 & 0.0 & 2.1 \\
\hline
\end{tabular}

${ }^{1}$ The nonexceedance percentile for the basin or climatic variable value was calculated in relation to the values for all streamgages included in the regional regression analyses for the indicated hydrologic region. 
Intuitively, the streamgage network in the Northwest hydrologic region might benefit from establishing a CSG on a basin with the specified characteristics.

About 56 percent of the streamgages in the Northwest hydrologic region are considered to have mixed-population characteristics (table 1). Identification and treatment of mixedpopulation datasets are specifically noted in Bulletin 17C (England and others, 2019) as a topic needing further study. Potential future advances in understanding and treatment of mixed-population datasets in frequency analysis might contribute to improvements in frequency analyses in the Northwest hydrologic region. Among the candidate explanatory variables included in the regional regression analyses, there are no variables that represent spatial variability in precipitation intensity (such as indices of the 100-year 24-hour precipitation; for example, U.S. Weather Bureau, 1961). Inclusion of variables that represent spatial variability in precipitation intensity might help address some mixed-population issues and improve potential future regional regression analyses in the Northwest hydrologic region. Future regional regression analyses for the Northwest hydrologic region might benefit from focused evaluation of appropriate regression methods for treatment of mixed-population datasets.

\section{Synopsis for the Northwest Foothills hydrologic region}

The median PFVI value for unregulated streamgages in the Northwest Foothills hydrologic region (27.17, table 3) ranks as the fourth largest among the eight hydrologic regions. The 1-percent AEP RRE for the Northwest Foothills hydrologic region has an SEP of 65.8 percent (table 6), which ranks fifth largest among the eight hydrologic regions. The 15 active unregulated streamgages (including six CSGs; table 3) represent an areal density of 0.00141 streamgage per $\mathrm{mi}^{2}$ (ranking sixth largest among hydrologic regions) and a density of 0.01438 streamgage per road and stream intersection (ranking seventh among hydrologic regions). These various characteristics might indicate that the streamgage network in the Northwest Foothills hydrologic region has a somewhat larger need for improvements than some of the other hydrologic regions.

The indicated possible shortcomings of the streamgage network in the Northwest Foothills hydrologic region include possible underrepresentation of basins with drainage area from about 30 to $225 \mathrm{mi}^{2}$, mean elevation from about 4,000 to $4,600 \mathrm{ft}$, and (or) mean annual precipitation from about 14 to 18 inches. Intuitively, the streamgage network in the Northwest hydrologic region might benefit from establishing several (possibly about four) CSGs on basins with the specified characteristics.

About 22 percent of the streamgages in the Northwest Foothills hydrologic region are considered to have mixedpopulation characteristics (table 1). Identification and treatment of mixed-population datasets are specifically noted in
Bulletin 17C (England and others, 2019) as a topic needing further study. Potential future advances in understanding and treatment of mixed-population datasets in frequency analysis might contribute to improvements in frequency analyses in the Northwest Foothills hydrologic region. Among the candidate explanatory variables included in the regional regression analyses, there are no variables that represent spatial variability in precipitation intensity (such as indices of the 100-year 24-hour precipitation; for example, U.S. Weather Bureau, 1961). Inclusion of variables that represent spatial variability in precipitation intensity might help address some mixedpopulation issues and improve potential future regional regression analyses in the Northwest Foothills hydrologic region.

\section{Synopsis for the Northeast Plains hydrologic region}

The median PFVI value for unregulated streamgages in the Northeast Plains hydrologic region (32.05, table 3) ranks as the third largest among the eight hydrologic regions. The 1-percent AEP RRE for the Northeast Plains hydrologic region has an SEP of 54.5 percent (table 6), which ranks seventh largest among the eight hydrologic regions. The 26 active unregulated streamgages (including 14 CSGs; table 3) represent an areal density of 0.00118 streamgage per $\mathrm{mi}^{2}$ (ranking eighth largest among hydrologic regions) and a density of 0.01769 streamgage per road and stream intersection (ranking fourth among hydrologic regions). These various characteristics might indicate that the streamgage network in the Northeast Plains hydrologic region has a smaller need for improvements than some of the other hydrologic regions.

The indicated possible shortcomings of the streamgage network in the Northeast Plains hydrologic region are minor and do not include clear underrepresentation of important basin characteristics. Intuitively, the Northeast Plains hydrologic region would not substantially benefit from revisions to the streamgaging network.

\section{Synopsis for the East-Central Plains hydrologic region}

The median PFVI value for unregulated streamgages in the East-Central Plains hydrologic region (36.00, table 3) ranks as the first largest among the eight hydrologic regions. The 1-percent AEP RRE for the East-Central Plains hydrologic region has an SEP of 73.5 percent (table 6), which ranks second largest among the eight hydrologic regions. The 36 active unregulated streamgages (including 27 CSGs; table 3) represent an areal density of 0.00127 streamgage per $\mathrm{mi}^{2}$ (ranking seventh largest among hydrologic regions) and a density of 0.02270 streamgage per road and stream intersection (ranking second among hydrologic regions). These various characteristics might indicate that the streamgage network in the East-Central Plains hydrologic region has a larger need for improvements than most of the other hydrologic regions. 
Small basins are more strongly represented in the East-Central Plains hydrologic region than most other hydrologic regions. It is noteworthy that about 58 percent of the streamgages (both regulated and unregulated) in the EastCentral Plains hydrologic region are on basins with drainage areas less than about $17 \mathrm{mi}^{2}$, whereas the other 42 percent of the streamgages are distributed over a large range in drainage areas from about 17 to several thousand square miles. In the East-Central Plains hydrologic region, the relatively large median PFVI value and high SEP for the 1-percent AEP RRE might be affected by strong representation of small basins. Intuitively, many (possibly about one-half) of the 27 active CSGs might be discontinued to free resources for redistributing CSGs to underrepresented hydroclimatic settings. The indicated possible shortcomings of the streamgage network in the East-Central Plains hydrologic region include underrepresentation of basins with drainage area from about 17 to $220 \mathrm{mi}^{2}$, mean elevation from about 3,600 to $4,000 \mathrm{ft}$, and (or) mean annual precipitation from about 15 to 16 inches. Intuitively, the streamgage network in the East-Central Plains hydrologic region might benefit from establishing several (possibly about four) CSGs on basins with the specified characteristics.

\section{Synopsis for the Southeast Plains hydrologic region}

The median $P F V I$ value for unregulated streamgages in the Southeast Plains hydrologic region (35.21, table 3) ranks as the second largest among the eight hydrologic regions. The 1-percent AEP RRE for the Southeast Plains hydrologic region has an SEP of 71.1 percent (table 6), which ranks third largest among the eight hydrologic regions. The 30 active unregulated streamgages (including 22 CSGs; table 3) represent an areal density of 0.00162 streamgage per $\mathrm{mi}^{2}$ (ranking third largest among hydrologic regions) and a density of 0.02188 streamgage per road and stream intersection (ranking third among hydrologic regions). These various characteristics might indicate that the streamgage network in the Southeast Plains hydrologic region has a larger need for improvements than most of the other hydrologic regions.

Small basins are more strongly represented in the Southeast Plains hydrologic region than most other hydrologic regions. It is noteworthy that about 63 percent of the streamgages (both regulated and unregulated) in the Southeast Plains hydrologic region are on basins with drainage areas less than about $20 \mathrm{mi}^{2}$, whereas the other 37 percent of the streamgages are distributed over a large range in drainage areas from about 20 to several thousand square miles. In the Southeast Plains hydrologic region, the relatively large median PFVI value and high SEP for the 1-percent AEP RRE might be affected by strong representation of small basins. Intuitively, many (possibly about one-half) of the 22 active CSGs might be discontinued to free resources for redistributing CSGs to underrepresented hydroclimatic settings. The indicated possible shortcomings of the streamgage network in the Southeast Plains hydrologic region include underrepresentation of basins with drainage area from about 20 to $370 \mathrm{mi}^{2}$, mean elevation from about 3,600 to $4,200 \mathrm{ft}$, and (or) mean annual precipitation from about 15 to 16 inches. Intuitively, the streamgage network in the Southeast Plains hydrologic region might benefit from establishing several (possibly about four) CSGs on basins with the specified characteristics.

\section{Synopsis for the Upper Yellowstone-Central Mountain hydrologic region}

The median PFVI value for unregulated streamgages in the Upper Yellowstone-Central Mountain hydrologic region (14.48, table 3$)$ ranks as the fifth largest among the eight hydrologic regions. The 1-percent AEP RRE for the Upper Yellowstone-Central Mountain hydrologic region has an SEP of 69.0 percent (table 6), which ranks fourth largest among the eight hydrologic regions. The 35 active unregulated streamgages (including 10 CSGs; table 3 ) represent an areal density of 0.00152 streamgage per $\mathrm{mi}^{2}$ (ranking fourth largest among hydrologic regions) and a density of 0.01616 streamgage per road and stream intersection (ranking sixth among hydrologic regions). These various characteristics might indicate that the streamgage network in the Upper Yellowstone-Central Mountain hydrologic region has a somewhat smaller need for improvements than some of the other hydrologic regions.

The indicated possible shortcomings of the streamgage network in the Upper Yellowstone-Central Mountain hydrologic region include small underrepresentation of basins with drainage areas from 10 to $32 \mathrm{mi}^{2}$, mean elevation less than about 5,100 ft, and (or) mean annual precipitation from 18 to 22 inches. Intuitively, the streamgage network in the Upper Yellowstone-Central Mountain hydrologic region might benefit from establishing a CSG on a basin with the specified characteristics.

\section{Synopsis for the Southwest hydrologic region}

The median PFVI value for unregulated streamgages in the Southwest hydrologic region (9.30, table 3 ) ranks as the sixth largest among the eight hydrologic regions. The 1-percent AEP RRE for the Southwest hydrologic region has an SEP of 73.8 percent (table 6), which ranks first largest among the eight hydrologic regions. The 29 active unregulated streamgages (including $8 \mathrm{CSGs}$; table 3 ) represent an areal density of 0.00195 streamgage per $\mathrm{mi}^{2}$ (ranking first largest among hydrologic regions) and a density of 0.01279 streamgage per road and stream intersection (ranking eighth among hydrologic regions). These various characteristics might indicate that the streamgage network in the Southwest hydrologic region has a somewhat larger need for improvements than some of the other hydrologic regions. 
The indicated possible shortcomings of the streamgage network in the Southwest hydrologic region include small underrepresentation of basins with drainage areas less than about $30 \mathrm{mi}^{2}$, mean elevation from about 5,000 to $6,800 \mathrm{ft}$, and (or) mean annual precipitation from 12 to 17 inches. Intuitively, the streamgage network in the Southwest hydrologic region might benefit from establishing several (possibly about four) CSGs on basins with the specified characteristics.

About 17 percent of the streamgages in the Southwest hydrologic region are considered to have mixed-population characteristics (table 1). Identification and treatment of mixedpopulation datasets are specifically noted in Bulletin 17C (England and others, 2019) as a topic needing further study. Potential future advances in understanding and treatment of mixed-population datasets in frequency analysis might contribute to improvements in frequency analyses in the Southwest hydrologic region. Among the candidate explanatory variables included in the regional regression analyses, there are no variables that represent spatial variability in precipitation intensity (such as indices of the 100-year 24-hour precipitation; for example, U.S. Weather Bureau, 1961). Inclusion of variables that represent spatial variability in precipitation intensity might help address some mixed-population issues and improve potential future regional regression analyses in the Southwest hydrologic region.

\section{Summary}

The U.S. Geological Survey (USGS), in cooperation with the Montana Department of Transportation (MDT), has operated a crest-stage gage (CSG) network in Montana to collect peak-flow data since 1955. The CSG network is vital to collecting peak-flow data on small drainage basins that typically are not addressed by continuous streamflow operations. Discussions between the USGS and MDT identified a need for evaluating the CSG network to allow for better decision making in the management of the network. The purpose of this report is to (1) generally describe peak-flow variability in Montana, (2) assess peak-flow informational needs relevant to MDT activities, and (3) consider the characteristics of the active CSG network in relation to addressing the informational needs. The evaluation of the CSG network is intended to assist in prioritization for discontinuation of CSGs and other activities involving changes to the CSG network.

Montana is a large State (147,000 square miles [ $\left.\left.\mathrm{mi}^{2}\right]\right)$ with large spatial variability in geologic, topographic, ecologic, and climatic characteristics; the large variability in these characteristics translates to large spatial variability in hydrologic regimes. Major drivers of peak-flow events in Montana include snowmelt, rainfall, and snowmelt with rainfall. Across Montana, large variability in climatic and topographic characteristics affects the spatial dominance among the major drivers and results in large variability in the flood regimes of streamgages. In conjunction with large variability in hydrologic regimes, the socioeconomic characteristics of Montana present substantial challenges for operating a large statewide streamgage network that consistently captures the hydrologic variability.

Peak-flow variability was investigated by analysis of selected peak-flow characteristics of 659 unregulated streamgages in or near Montana. A generalized peak-flow variability index $(P F V I)$ was developed to provide largescale representation of peak-flow variability in Montana. For unregulated Montana streamgages, PFVI generally monotonically decreases with increasing drainage area, although there is somewhat large (but generally consistent) variability about the locally weighted scatterplot smooth (LOWESS) line. Presumably, highly variable small-scale hydroclimatic processes are integrated with increasing drainage area such that variability in many hydrologic characteristics is reduced. $P F V I$ also decreases with increasing mean basin elevation and mean annual precipitation. Presumably, higher elevation and wetter hydroclimatic settings in Montana contribute to reduced variability in hydrologic characteristics. Intuitively, PFVI might be expected to generally decrease with increasing years of record because the standard deviation might typically be expected to decrease with increasing sample size. However, relations between $P F V I$ and years of record are more complex and variable than drainage area, elevation, and precipitation. PFVI variably increases from 10 to about 40 years of record, and then generally monotonically decreases from about 40 to about 105 years of record. Relations among PFVI and the years of record might be confounded by effects of drainage area because streamgages with long periods of record (greater than about 60 years) generally have large drainage areas (greater than about $100 \mathrm{mi}^{2}$ ).

The relations between PFVI and drainage area, mean basin elevation, mean annual precipitation, and years of record substantially differ among the eight hydrologic regions in Montana. As such, the PFVI relations were further investigated within each hydrologic region.

A major use of peak-flow information by the MDT is for design of road and highway infrastructure, including bridges, culverts, and roadside drainage ditches. As such, basin characteristics (including drainage area, mean basin elevation, and mean annual precipitation) of the Montana streamgage network (735 regulated and unregulated streamgages) were statistically investigated in relation to basin characteristics of 12,639 road and stream intersections in Montana. Both regulated and unregulated streamgages were investigated because the road and stream intersections are on both regulated and unregulated streams. Exploratory analyses indicated that the various relations substantially differ among the hydrologic regions. As such, the relations between the Montana streamgage network and the road and stream intersections were further investigated within each hydrologic region.

An important objective of the CSG network is to provide data for developing regional regression equations (RREs) for estimating frequencies at ungaged sites in Montana. In providing regional information, the CSG network is vital to 
collecting peak-flow data on small drainage basins that typically are not addressed by continuous streamflow operations. Various characteristics of the RREs substantially differ among the eight hydrologic regions in Montana. As such, the RRE characteristics were further investigated within each hydrologic region.

The West hydrologic region has an area of 21,371 $\mathrm{mi}^{2}$, which ranks fourth largest among the eight hydrologic regions. The 2,380 road and stream intersections in the West hydrologic region represent a density of 0.111 road and stream intersection per $\mathrm{mi}^{2}$, which ranks second among the hydrologic regions. The median $P F V I$ value for unregulated streamgages in the West hydrologic region (7.63) ranks as the seventh largest among the eight hydrologic regions. The 1-percent AEP RRE for the West hydrologic region has a mean standard error of prediction (SEP) of 56.0 percent, which ranks sixth largest among the eight hydrologic regions. The 41 active unregulated streamgages (with no CSGs) represent a density of 0.01723 streamgage per road and stream intersection (ranking fifth among hydrologic regions). These various characteristics might indicate that the streamgage network in the West hydrologic region has a smaller need for improvements than most of the other hydrologic regions.

Investigation of relations between the Montana streamgage network and the road and stream intersections indicated possible shortcomings of the streamgage network in the West hydrologic region, including no active CSGs, and possible underrepresentation of basins with drainage area less than about $5 \mathrm{mi}^{2}$, mean elevation less than about $4,000 \mathrm{ft}$, and (or) mean annual precipitation less than about 25 inches. The lack of active CSGs might contribute to poor understanding of effects of future climatic variability on small drainage basins in the West hydrologic region. Intuitively, the streamgage network in the West hydrologic region might benefit from establishing a CSG on a basin with the specified characteristics.

The Northwest hydrologic region has an area of $7,938 \mathrm{mi}^{2}$, which ranks eighth largest among the eight hydrologic regions. The 356 road and stream intersections in the Northwest hydrologic region represent a density of 0.045 road and stream intersection per $\mathrm{mi}^{2}$, which ranks eighth among the hydrologic regions. The median $P F V I$ value for streamgages in the Northwest hydrologic region (6.04) ranks as the eighth largest among the eight hydrologic regions. The 1-percent AEP RRE for the Northwest hydrologic region has an SEP of 13.6 percent, which ranks eighth largest among the eight hydrologic regions. The RREs for the Northwest hydrologic region were developed using weighted least squares regression to better handle complexities introduced by the large proportion of mixed-population peak-flow datasets; the use of weighted least squares regression might contribute to the low SEP. The 12 active unregulated streamgages (including $1 \mathrm{CSG}$ ) represent an areal density of 0.00151 streamgage per $\mathrm{mi}^{2}$ (ranking fifth largest among hydrologic regions) and a density of 0.03371 streamgage per road and stream intersection (ranking first among hydrologic regions). These various characteristics might indicate that the streamgage network in the Northwest hydrologic region has a smaller need for improvements than most of the other hydrologic regions.

Investigation of relations between the Montana streamgage network and the road and stream intersections indicated possible shortcomings of the streamgage network in the Northwest hydrologic region include possible underrepresentation of basins with drainage area less than about $125 \mathrm{mi}^{2}$, mean elevation less than about 5,400 ft, and (or) mean annual precipitation less than about 37 inches. Intuitively, the streamgage network in the Northwest hydrologic region might benefit from establishing a CSG on a basin with the specified characteristics.

The Northwest Foothills hydrologic region has an area of 10,624 $\mathrm{mi}^{2}$, which ranks seventh largest among the eight hydrologic regions. The 1,043 road and stream intersections in the Northwest Foothills hydrologic region represent a density of 0.098 road and stream intersection per $\mathrm{mi}^{2}$, which ranks third among the hydrologic regions. The median PFVI value for unregulated streamgages in the Northwest Foothills hydrologic region (27.17) ranks as the fourth largest among the eight hydrologic regions. The 1-percent AEP RRE for the Northwest Foothills hydrologic region has an SEP of 65.8 percent, which ranks fifth largest among the eight hydrologic regions. The 15 active unregulated streamgages (including 6 CSGs) represent an areal density of 0.00141 streamgage per $\mathrm{mi}^{2}$ (ranking sixth largest among hydrologic regions) and a density of 0.01438 streamgage per road and stream intersection (ranking seventh among hydrologic regions). These various characteristics might indicate that the streamgage network in the Northwest Foothills hydrologic region has a somewhat larger need for improvements than some of the other hydrologic regions.

Investigation of relations between the Montana streamgage network and the road and stream intersections indicated possible shortcomings of the streamgage network in the Northwest Foothills hydrologic region include possible underrepresentation of basins with drainage area from about 30 to $225 \mathrm{mi}^{2}$, mean elevation from about 4,000 to $4,600 \mathrm{ft}$, and (or) mean annual precipitation from about 14 to 18 inches. Intuitively, the streamgage network in the Northwest Foothills hydrologic region might benefit from establishing several (possibly about four) CSGs on basins with the specified characteristics.

The Northeast Plains hydrologic region has an area of $22,059 \mathrm{mi}^{2}$, which ranks third largest among the eight hydrologic regions. The 1,470 road and stream intersections in the Northeast Plains hydrologic region represent a density of 0.067 road and stream intersection per $\mathrm{mi}^{2}$, which ranks sixth among the hydrologic regions. The median PFVI value for unregulated streamgages in the Northeast Plains hydrologic region (32.05) ranks as the third largest among the eight hydrologic regions. The 1-percent AEP RRE for the Northeast Plains hydrologic region has an SEP of 54.5 percent, which ranks seventh largest among the eight hydrologic regions. The 26 active unregulated streamgages (including 14 CSGs) 
represent an areal density of 0.00118 streamgage per $\mathrm{mi}^{2}$ (ranking eighth largest among hydrologic regions) and a density of 0.01769 streamgage per road and stream intersection (ranking fourth among hydrologic regions). These various characteristics might indicate that the streamgage network in the Northeast Plains hydrologic region has a smaller need for improvements than some of the other hydrologic regions.

Investigation of relations between the Montana streamgage network and the road and stream intersections indicated possible shortcomings of the streamgage network in the Northeast Plains hydrologic region are minor and do not include clear underrepresentation of important basin characteristics. Intuitively, the Northeast Plains hydrologic region would not substantially benefit from revisions to the streamgaging network.

The East-Central Plains hydrologic region has an area of $28,451 \mathrm{mi}^{2}$, which ranks first largest among the eight hydrologic regions. The 1,586 road and stream intersections in the East-Central Plains hydrologic region represent a density of 0.056 road and stream intersection per $\mathrm{mi}^{2}$, which ranks seventh among the hydrologic regions. The median PFVI value for unregulated streamgages in the East-Central Plains hydrologic region (36.00) ranks as the first largest among the eight hydrologic regions. The 1-percent AEP RRE for the East-Central Plains hydrologic region has an SEP of 73.5 percent, which ranks second largest among the eight hydrologic regions. The 36 active unregulated streamgages (including 27 CSGs) represent an areal density of 0.00127 streamgage per $\mathrm{mi}^{2}$ (ranking seventh largest among hydrologic regions) and a density of 0.02270 streamgage per road and stream intersection (ranking second among hydrologic regions). These various characteristics might indicate that the streamgage network in the East-Central Plains hydrologic region has a larger need for improvements than most of the other hydrologic regions.

Small basins are more strongly represented in the East-Central Plains hydrologic region than most other hydrologic regions. It is noteworthy that about 58 percent of the streamgages (both regulated and unregulated) in the EastCentral Plains hydrologic region are on basins with drainage areas less than about $17 \mathrm{mi}^{2}$, whereas the other 42 percent of the streamgages are distributed over a large range in drainage areas from about 17 to several thousand square miles. In the East-Central Plains hydrologic region, the relatively large median PFVI value and high SEP for the 1-percent AEP RRE might be affected by strong representation of small basins. Intuitively, many (possibly about one-half) of the 27 active CSGs might be discontinued to free resources for redistributing CSGs to underrepresented hydroclimatic settings. Investigation of relations between the Montana streamgage network and the road and stream intersections indicated possible shortcomings of the streamgage network in the EastCentral Plains hydrologic region include underrepresentation of basins with contributing drainage area (CONTDA) from about 17 to $220 \mathrm{mi}^{2}$, mean elevation from about 3,600 to $4,000 \mathrm{ft}$, and (or) mean annual precipitation from about 15 to
16 inches. Intuitively, the streamgage network in the EastCentral Plains hydrologic region might benefit from establishing several (possibly about four) CSGs on basins with the specified characteristics.

The Southeast Plains hydrologic region has an area of $18,520 \mathrm{mi}^{2}$, which ranks fifth largest among the eight hydrologic regions. The 1,371 road and stream intersections in the Southeast Plains hydrologic region represent a density of 0.074 road and stream intersection per $\mathrm{mi}^{2}$, which ranks fifth among the hydrologic regions. The median PFVI value for unregulated streamgages in the Southeast Plains hydrologic region (35.21) ranks as the second largest among the eight hydrologic regions. The 1-percent AEP RRE for the Southeast Plains hydrologic region has an SEP of 71.1 percent, which ranks third largest among the eight hydrologic regions. The 30 active unregulated streamgages (including 22 CSGs) represent an areal density of 0.00162 streamgage per $\mathrm{mi}^{2}$ (ranking third largest among hydrologic regions) and a density of 0.02188 streamgage per road and stream intersection (ranking third among hydrologic regions). These various characteristics might indicate that the streamgage network in the Southeast Plains hydrologic region has a larger need for improvements than most of the other hydrologic regions.

Small basins are more strongly represented in the Southeast Plains hydrologic region than most other hydrologic regions. It is noteworthy that about 63 percent of the streamgages (both regulated and unregulated) in the Southeast Plains hydrologic region are on basins with drainage areas less than about $20 \mathrm{mi}^{2}$; whereas, the other 37 percent of the streamgages are distributed over a large range in drainage areas from about 20 to several thousand square miles. In the Southeast Plains hydrologic region, the relatively large median PFVI value and high SEP for the 1-percent AEP RRE might be affected by strong representation of small basins. Intuitively, many (possibly about one-half) of the 22 active CSGs might be discontinued to free resources for redistributing CSGs to underrepresented hydroclimatic settings. Investigation of relations between the Montana streamgage network and the road and stream intersections indicated possible shortcomings of the streamgage network in the Southeast Plains hydrologic region include underrepresentation of basins with CONTDA from about 20 to $370 \mathrm{mi}^{2}$, mean elevation from about 3,600 to $4,200 \mathrm{ft}$, and (or) mean annual precipitation from about 15 to 16 inches. Intuitively, the streamgage network in the Southeast Plains hydrologic region might benefit from establishing several (possibly about four) CSGs on basins with the specified characteristics.

The Upper Yellowstone-Central Mountain hydrologic region has an area of $23,003 \mathrm{mi}^{2}$, which ranks second largest among the eight hydrologic regions. The 2,166 road and stream intersections in the Upper Yellowstone-Central Mountain hydrologic region represent a density of 0.094 road and stream intersection per $\mathrm{mi}^{2}$, which ranks fourth among the hydrologic regions. The median PFVI value for unregulated streamgages in the Upper Yellowstone-Central Mountain hydrologic region (14.48) ranks as the fifth largest among 
the eight hydrologic regions. The 1-percent AEP RRE for the Upper Yellowstone-Central Mountain hydrologic region has an SEP of 69.0 percent, which ranks fourth largest among the eight hydrologic regions. The 35 active unregulated streamgages (including $10 \mathrm{CSGs}$ ) represent an areal density of 0.00152 streamgage per $\mathrm{mi}^{2}$ (ranking fourth largest among hydrologic regions) and a density of 0.01616 streamgage per road and stream intersection (ranking sixth among hydrologic regions). These various characteristics might indicate that the streamgage network in the Upper Yellowstone-Central Mountain hydrologic region has a somewhat smaller need for improvements than some of the other hydrologic regions.

Investigation of relations between the Montana streamgage network and the road and stream intersections indicated possible shortcomings of the streamgage network in the Upper Yellowstone-Central Mountain hydrologic region include small underrepresentation of basins with drainage areas from 10 to $32 \mathrm{mi}^{2}$, mean basin elevation less than about 5,100 ft, and (or) mean annual precipitation from 18 to 22 inches. Intuitively, the streamgage network in the Upper Yellowstone-Central Mountain hydrologic region might benefit from establishing a CSG on a basin with the specified characteristics.

The Southwest hydrologic region has an area of $14,891 \mathrm{mi}^{2}$, which ranks sixth largest among the eight hydrologic regions. The 2,267 road and stream intersections in the Southwest hydrologic region represent a density of 0.152 road and stream intersection per $\mathrm{mi}^{2}$, which ranks first among the hydrologic regions. The median $P F V I$ value for unregulated streamgages in the Southwest hydrologic region (9.30) ranks as the sixth largest among the eight hydrologic regions. The 1-percent AEP RRE for the Southwest hydrologic region has an SEP of 73.8 percent, which ranks first largest among the eight hydrologic regions. The 29 active unregulated streamgages (including $8 \mathrm{CSGs}$ ) represent an areal density of 0.00195 streamgage per $\mathrm{mi}^{2}$ (ranking first largest among hydrologic regions) and a density of 0.01279 streamgage per road and stream intersection (ranking eighth among hydrologic regions). These various characteristics might indicate that the streamgage network in the Southwest hydrologic region has a somewhat larger need for improvements than some of the other hydrologic regions.

Investigation of relations between the Montana streamgage network and the road and stream intersections indicated possible shortcomings of the streamgage network in the Southwest hydrologic region include small underrepresentation of basins with drainage areas in the range less than about $30 \mathrm{mi}^{2}$, mean elevation from about 5,000 to $6,800 \mathrm{ft}$, and (or) mean annual precipitation from 12 to 17 inches. Intuitively, the streamgage network in the Southwest hydrologic region might benefit from establishing several (possibly about four) CSGs on basins with the specified characteristics.

Four hydrologic regions have substantial percentages of streamgages considered to have mixed-population characteristics: the West (about 12.5 percent), Northwest (about 56 percent), Northwest Foothills (about 22 percent), and Southwest (about 17 percent). Often, mixed-population datasets result from unusually large peak-flow events caused by extremely intense rainfall events in May and June that happen near the peak of snowmelt runoff.

Potential future advances in understanding and treatment of mixed-population datasets in frequency analysis might contribute to improvements in frequency analyses in the four hydrologic regions with substantial mixed-population characteristics. Among the candidate explanatory variables included in the regional regression analyses, there are no variables that represent spatial variability in precipitation intensity. Inclusion of variables that represent spatial variability in precipitation intensity might help address some mixed-population issues and improve potential future regional regression analyses in the four hydrologic regions.

\section{References Cited}

Cleveland, W.S., 1985, The elements of graphing data: Monterey, Calif., Wadsworth Books, 323 p.

Dutton, D.D., Sando, R., and Sando, S.K., 2021, Drainagebasin characteristics associated with 12,639 road and stream intersections in Montana: U.S. Geological Survey data release, https://doi.org/10.5066/P9NZX5TM.

England, J.F., Jr., Cohn, T.A., Faber, B.A., Stedinger, J.R., Thomas, W.O., Jr., Veilleux, A.G., Kiang, J.E., and Mason, R.R., Jr., 2019, Guidelines for determining flood flow frequency-Bulletin 17C (ver. 1.1, May 2019): U.S. Geological Survey Techniques and Methods, book 4, chap. B5, 148 p. [Also available at https://doi.org/ 10.3133/tm4B5.]

Gesch, D., Oimoen, M., Greenlee, S., Nelson, C., Steuck, M., and Tyler, D., 2002, The National Elevation Dataset: Photogrammetric Engineering and Remote Sensing, v. 68 , p. $5-11$.

Homer, C., Dewitz, J., Fry, J., Coan, M., Hossain, N., Larson, C., Herold, N., McKerrow, A., VanDriel, J.N., and Wickham, J., 2007, Completion of the 2001 National Land Cover Database for the conterminous United States: Photogrammetric Engineering and Remote Sensing, v. 73, p. 337-341.

Horizon Systems Corporation, 2013, NHDPlus version 2: Horizons Systems Corporation, web page, accessed January 16, 2014, at http://www.horizon-systems.com/ NHDPlus/NHDPlusV2_home.php. [Now available at https://nhdplus.com/NHDPlus/NHDPlusV2_home.php.] 
McCarthy, P.M., Dutton, D.M., Sando, S.K., and Sando, R., 2016, Montana StreamStats - A method for retrieving basin and streamflow characteristics in Montana: U.S. Geological Survey Scientific Investigations Report 2015-5019-A, 16 p. [Also available at https://doi.org/10.3133/sir20155019A.]

Montana Department of Revenue, 2014, Revenue Final Land Unit (FLU) classification: accessed December 16, 2014, at ftp://ftp.geoinfo.msl.mt.gov/Data/Spatial/NonMSDI/ Geodatabases/revenue_flu.zip.

Montana State Library, 2019, Geographic Information Clearinghouse Transportation dataset: Montana State Library, digital data, accessed March 28, 2019, at https:/ /geoinfo.msl.mt.gov/msdi/transportation/.

Parrett, C., and Johnson, D.R., 2004, Methods for estimating flood frequency in Montana based on data through water year 1998: U.S. Geological Survey Water-Resources Investigations Report 03-4308, 101 p. [Also available at https://doi.org/10.3133/wri034308.]

PRISM Climate Group, 2004, PRISM climate data: Oregon State University, accessed November 7, 2016, at https://prism.oregonstate.edu/.

Sando, R., Sando, S.K., McCarthy, P.M., and Dutton, D.M., 2018, Methods for estimating peak-flow frequencies at ungaged sites in Montana based on data through water year 2011 (ver. 1.1, February 2018): U.S. Geological Survey Scientific Investigations Report 2015-5019-F, 30 p. [Also available at https://doi.org/10.3133/sir20155019F.]

Sando, S.K., and McCarthy, P.M., 2018, Methods for peakflow frequency analysis and reporting for streamgages in or near Montana based on data through water year 2015: U.S. Geological Survey Scientific Investigations Report 2018-5046, 39 p. [Also available at https://doi.org/10.3133/ sir20185046.]

Sando, S.K., McCarthy, P.M., and Dutton, D.M., 2016, Peakflow frequency analyses and results based on data through water year 2011 for selected streamflow-gaging stations in or near Montana: U.S. Geological Survey Scientific Investigations Report 2015-5019-C, 27 p. [Also available at https://doi.org/10.3133/sir20155019C.]

U.S. Census Bureau, 2016, U.S. Census Bureau web site: accessed on December 13, 2016, at https://www.c ensus.gov/.

U.S. Environmental Protection Agency, 2015, Level III and IV ecoregions of the continental United States: U.S. Environmental Protection Agency, web page, accessed November 1, 2016, at https://www.epa.gov/eco-research/ level-iii-and-iv-ecoregions-continental-united-states.
U.S. Geological Survey, 2018, USGS water data for the Nation: U.S. Geological Survey National Water Information System database, accessed March 20, 2018, at https://doi.org/10.5066/F7P55KJN.

U.S. Interagency Advisory Committee on Water Data, 1982, Guidelines for determining flood flow frequency: U.S. Interagency Advisory Committee on Water Data, Hydrology Subcommittee, Bulletin 17B, 28 p.

U.S. Weather Bureau, 1961, Rainfall frequency atlas of the United States: U.S. Weather Bureau, Technical Paper 40, 115 p. 
For more information about this publication, contact: Director, USGS Wyoming-Montana Water Science Center 3162 Bozeman Avenue

Helena, MT 59601

406-457-5900

For additional information, visit: https://www.usgs.gov/centers/wymt-water/

Publishing support provided by the

Rolla Publishing Service Center 
